\title{
पLBER
}

JOANNA PRACKA

\section{TEMPERAMENT I PLEĆ A INTELIGENCJA EMOCJONALNA}

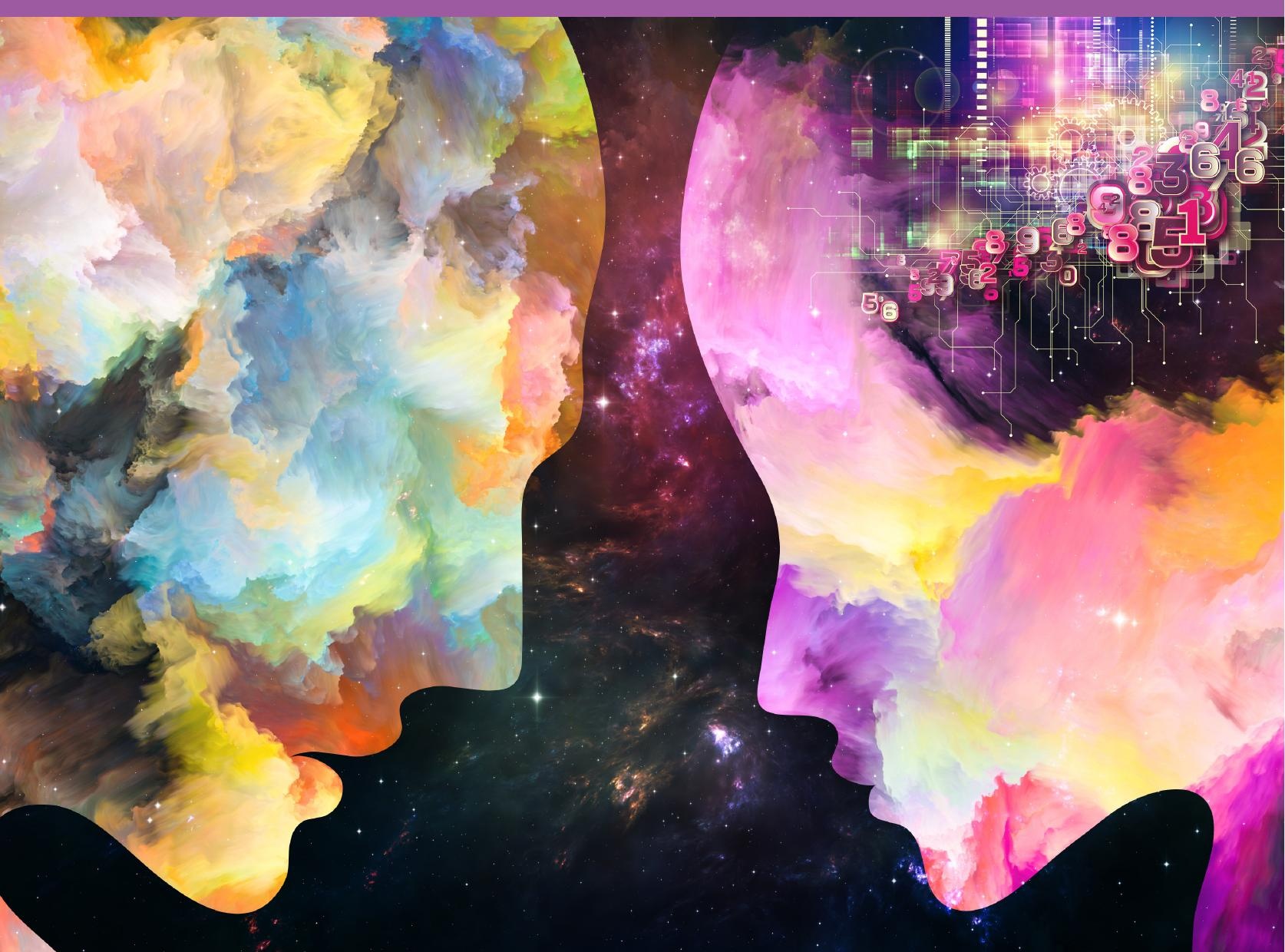




\section{TEMPERAMENT I PŁEĆ A INTELIGENCJA EMOCJONALNA}

JOANNA PRACKA 



\section{TEMPERAMENT I PŁEĆ A INTELIGENCJA EMOCJONALNA}

JOANNA PRACKA 
Joanna Pracka (iD) https://orcid.org/0000-0002-2664-2816

Temperament i płeć a inteligencja emocjonalna

\section{Recenzenci:}

dr Katarzyna Knopp (UKSW w Warszawie)

\section{Projekt okładki:}

Dominika Karaś

\section{Ilustracja na okładce:}

shutterstock.com

\section{Korekta językowa:}

Gabriela Steliga

Małgorzata Najderska

\section{Skład i łamanie:}

Justyna Harasimczuk

\section{(c) (1)}

Publikacja jest udostępniona na licencji Creative Commons Uznanie autorstwa 4.0.

Treść licencji jest dostępna na stronie: https://creativecommons.org/licenses/by/4.0/

Publikacja dofinansowana ze środków Uniwersytetu Szczecińskiego

Warszawa: Wydawnictwo Liberi Libri, 2021

www.LiberiLibri.pl

ISBN: 978-83-63487-52-2

DOI: $10.47943 / \mathrm{lib} .9788363487522$ 


\section{SPIS TREŚCI}

Wstęp

\section{POJĘCIE INTELIGENCJI EMOCJONALNEJ}

1.1. Geneza pojęcia inteligencji emocjonalnej

1.2. Sposoby rozumienia inteligencji emocjonalnej

1.2.1. Inteligencja emocjonalna jako zbiór zdolności

1.2.2. Inteligencja emocjonalna jako zbiór cech osobowości

1.2.3. Inteligencja emocjonalna jako zbiór kompetencji

1.2.4. Inteligencja emocjonalna jako poczucie własnej skuteczności

1.3. Inteligencja emocjonalna a inne rodzaje inteligencji

1.4. Typy inteligencji emocjonalnej

1.4.1. Inteligencja emocjonalna interpersonalna vs. intrapersonalna

1.4.2. Inteligencja emocjonalna poznawcza vs. działaniowa

1.4.3. Inteligencja emocjonalna doświadczeniowa vs. strategiczna

1.5. Odniesienie inteligencji emocjonalnej do poznawczodoświadczeniowej teorii osobowości Seymoura Epsteina 1.6. Inteligencja emocjonalna a wiedza emocjonalna deklaratywna vs. proceduralna

\section{POMIAR INTELIGENCJI EMOCJONALNEJ}

2.1. Pomiar testowy

2.2. Pomiar kwestionariuszowy

2.3. Inne rodzaje pomiaru

\section{ZNACZENIE INTELIGENCJ EMOCJONALNEJ} W FUNKCJONOWANIU CZŁOWIEKA

\section{RÓŻNICE MIĘDZYPŁCIOWE W ZAKRESIE INTELIGENCJI} EMOCJONALNEJ

4.1. Przegląd danych z literatury

4.2. Prezentacja wyników badań własnych

4.2.1. Profile inteligencji emocjonalnej kobiet i mężczyzn w odniesieniu do inteligencji emocjonalnej doświadczeniowej vs. strategicznej 

i działaniowej

76

81

81

87

90

90

99

103

105

4.3. Dyskusja

\section{5. ŚRODOWISKOWE UWARUNKOWANIA ROZWOJU INTELIGENCJI EMOCJONALNEJ}

5.1. Rola środowiska rodzinnego w rozwoju inteligencji emocjonalnej

5.2. Wpływ postaw i stylów rodzicielskich na inteligencję emocjonalną

\section{TEMPERAMENTALNE UWARUNKOWANIA INTELIGENCJI EMOCJONALNEJ}

6.1. Inteligencja emocjonalna a różne cechy osobowości

6.2. Rola temperamentu $w$ rozwoju inteligencji emocjonalnej

6.3. Związki pomiędzy inteligencją emocjonalną a wybranymi cechami temperamentu

6.4. Cechy temperamentu w Regulacyjnej Teorii Temperamentu a inteligencja emocjonalna

6.4.1. Regulacyjna Teoria Temperamentu

6.4.2. Potwierdzone empirycznie zależności pomiędzy temperamentem w ujęciu Regulacyjnej Teorii Temperamentu a inteligencją emocjonalną

6.5. Prezentacja wyników badań własnych

6.5.1. Przyjęte założenia

6.5.2. Korelacje pomiędzy inteligencją emocjonalną a cechami temperamentu

6.5.3. Możliwości przetwarzania stymulacji a inteligencja emocjonalna

6.5.4. Zharmonizowanie temperamentu a inteligencja emocjonalna

6.5.5. Profile temperamentu a inteligencja emocjonalna u kobiet i mężczyzn

6.5.6. Dyskusja

Podsumowanie

Bibliografia

Załączniki 


\section{WSTĘP}

Opozycyjność, jaka dawniej istniała w myśleniu uczonych na temat funkcjonowania emocjonalnego i poznawczego człowieka oraz uznawanie wyższości tego drugiego bardzo dobrze wyrażało klasyczne stwierdzenie Kartezjusza: Cogito ergo sum (za: Ammaniti, 2008). Przed Kartezjuszem już Platon przedstawiał obraz człowieka za pomocą dwóch rumaków, białego i czarnego, symbolizujących sferę popędowo-pożądliwą człowieka (a dokładnie: duszę popędową i duszę pożądliwą), którymi powozi sprawujący nad nimi kontrolę woźnica, czyli rozum (por. Platon, tłum. 2002). Wiele wieków później psychoanaliza, z Freudem na czele (por. Freud, 1994, 1997), podjęła temat tego konfliktu między instynktem a rozumem, uznając, że ludzkie popędy („narowiste” libido), jak sugerowała, powinny być udomowione przez ego, symbolizowane przez racjonalnego jeźdźca Platona. Do dzisiaj niektórzy stawiają sobie pytanie o to, jakie miejsce zajmują emocje w codziennym życiu człowieka: są namiętnościami, które oślepiają rozum, czy też uczuciami, które mają ścisły cel i użyteczność? Wielu badaczy uznało ewolucjonistyczną racjonalność emocji, jak choćby sam Darwin, który podkreślał w swojej książce z 1872 roku (za: Ammaniti, 2008), że emocje ewoluowały na przestrzeni wieków, żeby ułatwiać przystosowanie do środowiska oraz wymianę społeczną. Zatem można uznać, że współcześnie nastąpiła totalna zmiana optyki patrzenia na sprawę sfery emocjonalnej człowieka, a to, między innymi, być może także za sprawą pojawienia się pojęcia inteligencji emocjonalnej. Choć możliwe również, że zależność jest tu odwrotna: pojęcie inteligencji emocjonalnej pojawiło się na skutek zniesienia dualizmu „emocje-intelekt”, czy też jest jego wyrazem. Kartezjusz stwierdzał: „Myślę, więc jestem". Twórcy pojęcia inteligencji emocjonalnej zdają się przekonywać: „Czuję i myślę, więc jestem”. Zdrowy rozsądek (sic!) oraz doświadczenie, pochodzące między innymi z takich obszarów jak psychologia kliniczna czy psychoterapia, potwierdzają, że tylko „pojednanie” ze sobą tych dwóch sfer funkcjonowania i ich harmonijna „współpraca” prowadzą do pełni rozwoju znajdującego wyraz w zdrowej, dojrzałej i zintegrowanej osobowości człowieka. Także dane empiryczne potwierdzają, że chociaż podział psychiki ludzkiej na intelekt, emocje i motywacje pozwala na analizy naukowe tych konstruktów, to jednak nie znajduje odzwierciedlenia w rzeczywistości (np. Damasio, 1999); stąd także badacze postulują konieczność holistycznego 
ujmowania psychiki ludzkiej (np. Goleman, 1997; Greenspan, Benderly, 2000; LeDoux, 2000; Mayer, Salovey, 1999).

Inteligencja emocjonalna jest pojęciem nadal dość ogólnym, które jest różnie interpretowane przez badaczy. Powstanie tego pojęcia jest kolejnym krokiem w kierunku bardziej zintegrowanego ujmowania psychiki ludzkiej, być może krokiem, który w jakiś sposób odpowiada na istniejące zapotrzebowanie w tym kierunku. Bardziej „purystyczni” przedstawiciele ujmowania inteligencji emocjonalnej łączą w niej dwa - traktowane dawniej jako opozycyjne - aspekty funkcjonowania człowieka: poznawczy i afektywny. Natomiast bardziej liberalnie podchodzący do tego konstruktu badacze rozszerzają go również o aspekt motywacyjny. W tej ostatniej wersji inteligencja emocjonalna staje się już zatem „czymś”, co przejawia się na wszystkich poziomach funkcjonowania człowieka, warunkuje je i jest zarazem przez nie warunkowana. Dla zwykłego śmiertelnika, który nie zna się na psychologii, może być to zatem atrakcyjne ujęcie tego, co w życiu ważne (na płaszczyźnie psychologicznej); w dużym uproszczeniu można by to ująć tak: „Posiadając inteligencję emocjonalną, mam wszystko, czego potrzeba”.

Celem niniejszej monografii jest próba przybliżenia się do prawdy na temat inteligencji emocjonalnej, wychodząc od przeglądu dotychczasowej wiedzy na jej temat, aż po analizę rezultatów badań własnych. Dwie główne kwestie podjęte przeze mnie to różnice międzypłciowe $\mathrm{w}$ inteligencji emocjonalnej (rozdział 3) oraz zależności między inteligencją emocjonalną a temperamentem (rozdział 6). Wspomniane części książki poprzedza szerokie wprowadzenie teoretyczne.

W rozdziale 1 omówione zostało pojęcie inteligencji emocjonalnej, jego geneza, różne sposoby rozumienia i definiowania tego konstruktu, odniesienie do innych rodzajów inteligencji. Są w nim zaprezentowane również różne typy inteligencji emocjonalnej pokazujące, że jest ona konstruktem złożonym i wielowymiarowym. Rozdział ten zawiera także, stworzone przeze mnie, zupełnie nowatorskie i oryginalne odniesienie koncepcji inteligencji emocjonalnej do poznawczo-doświadczeniowej teorii Seymoura Epsteina, która daje nowe możliwości rozważań nad konstruktem inteligencji emocjonalnej.

$\mathrm{W}$ rozdziale 2 podjęty został wątek pomiaru inteligencji emocjonalnej. Przedstawiono w nim główne, najczęściej stosowane, narzędzia do jej badania. 
W rozdziale 3 zostało opisane funkcjonalne znaczenie inteligencji emocjonalnej, uwzględniające obszary, na które może ona wpływać, a zarazem dementując przekonanie, że posiadanie wysokiej inteligencji emocjonalnej jest gwarantem szeroko pojętego sukcesu życiowego.

W rozdziale 4 podjęta została refleksja nad różnicami międzypłciowymi w odniesieniu do inteligencji emocjonalnej. Przedstawione są w nim wyniki dotyczasowych badań w tym temacie oraz wyniki badań własnych uwzględniające nie tylko ogólny poziom inteligencji emocjonalnej, ale też - co w dotychczasowych badaniach jest unikalne - jej analizę profilową. Rezultaty ukazują zarówno mocne strony kobiet, jak i mocne strony mężczyzn w zakresie inteligencji emocjonalnej, jednocześnie obalając potoczny mit, jakoby któraś z płci charakteryzowała się wyższym ogólnym poziomem inteligencji emocjonalnej.

Rozdział 5 opisuje rolę środowiskowych uwarunkowań inteligencji emocjonalnej, pokazując ważność kontekstu rodzinnego, stylów i postaw rodzicielskich dla kształtowania się inteligencji emocjonalnej, które są czynnikami mogącymi sprzyjać jej rozwojowi lub hamującymi go.

Rozdział 6 jest poświęcony tematowi temperamentalnych uwarunkowań inteligencji emocjonalnej. Wyniki dotyczasowych badań nad wpływem temperamentu na kształtowanie się zdolności emocjonalnych nie są tak jednoznaczne, jak mogłoby się z początku wydawać w świetle tworzonych modeli teoretycznych. Nakreślam stan obecnej wiedzy na ten temat, jednocześnie ukazując istniejące w tej wiedzy luki. Badania własne są próbą pomniejszenia tej luki, stanowiąc nowatorski wkład w poszerzenie wiedzy na temat zależności pomiędzy inteligencją emocjonalną a temperamentem. Jako podstawę teoretyczną badań przyjęłam Regulacyjną Teorię Temperamentu J. Strelaua - teorię bardzo nośną w kontekście rozważań nad inteligencją emocjonalną, a jednak poza Polską w takich rozważaniach pomijaną. Dotychczas podejmowane badania koncentrowały się głównie na identyfikowaniu związków między pojedynczymi cechami temperamentu i zdolnościami emocjonalnymi. W swoich badaniach poszukiwałam zależności między całymi strukturami temperamentu a inteligencją emocjonalną. Przyglądałam się tym związkom w wielu różnych perspektyw, uwzględniając różne konfiguracje zdolności wchodzących w skład inteligencji emocjonalnej (inteligencja emocjonalna doświadczeniowa vs. strategiczna, inteligencja emocjonalna poznawcza vs. działaniowa) oraz 
cech temperamentu (temperament warunkujący małe vs. duże możliwości przetwarzania stymulacji, zharmonizowana vs. niezharmonizowana struktura temperamentu).

Podjęta przeze mnie w tej książce problematyka może być interesująca dla różnych grup odbiorców. Pomimo naukowego charakteru może znaleźć czytelników nie tylko wśród psychologów zajmujących się psychologią naukowo, ale także wśród psychologów-praktyków, pedagogów, a także wszystkich osób zainteresowanych inteligencją emocjonalną. Głębsze zrozumienie temperamentalnych podstaw kształtowania się inteligencji emocjonalnej może mieć bowiem duże znaczenie m.in. dla konstruowania optymalnych oddziaływań psychoedukacyjnych, wychowawczych czy profilaktycznych, które mogą stymulować rozwój zdolności emocjonalnych lub niwelować deficyty w ich zakresie. 


\section{Rozdział 1.}

\section{Pojęcie inteligencji emocjonalnej}

\subsection{Geneza pojęcia inteligencji emocjonalnej}

Pierwsze próby rozszerzenia pojęcia tradycyjnie rozumianej inteligencji i wyjścia w jej rozumieniu poza aspekt wyłącznie poznawczy pojawiły się u Thorndike’a (1920, za: Nęcka, 2003), który w jej obrębie wyróżnił trzy główne równorzędne grupy zdolności: inteligencję abstrakcyjną, decydującą o tym, jak radzimy sobie ze światem pojęć i idei, inteligencję techniczną, dotyczącą naszych umiejętności radzenia sobie ze światem rzeczy oraz inteligencję społeczną, obejmującą zdolności rozumienia ludzi i mądrego postępowania w kontaktach z nimi (Newsome, Day, Catano, 2000; por. Szczygieł, 2006), czyli ogólnie rzecz biorąc - dobrego funkcjonowania w świecie społecznym.

Jeśli zatem mowa o zdolności zrozumienia innych ludzi, to zawiera się w niej zdolność rozumienia różnych dyspozycji psychicznych warunkujących ich zachowanie, $w$ tym dyspozycji o charakterze emocjonalnym, a więc zdolność rozumienia emocji i uczuć innych, co implicite stanowi już o jej związku z takim konstruktem, jak inteligencja emocjonalna, którą można potraktować jako wchodzącą w zakres inteligencji społecznej. Propozycja Thorndike’a zatem nie tylko zainspirowała rozwój myśli nad inteligencją społeczną, ale także dała podwaliny poszukiwań prowadzących w kierunku powstania konstruktu inteligencji emocjonalnej.

W latach 90. ubiegłego stulecia Gardner (1983) przedstawił swoją koncepcję inteligencji wielorakich, postulując istnienie wielu różnych rodzajów inteligencji, istniejących niezależnie od siebie. Gardner wymienił, obok inteligencji językowej, matematycznej, przestrzennej, kinestetycznej i muzycznej, także inteligencję personalną, rozróżniając w jej obrębie dwa 
rodzaje: intrapersonalną i interpersonalną, zdefiniowane następująco: „Sednem inteligencji interpersonalnej jest zdolność rozróżniania i właściwego reagowania na nastroje, temperamenty, motywacje i pragnienia innych osób (...) istotą inteligencji intrapersonalnej jest dostęp do swych własnych uczuć i zdolność rozróżniania ich oraz polegania na nich w kierowaniu swym zachowaniem" (Gardner, 1983, s. 9; por. Maruszewski, Ścigała, 1997). Pierwsza z nich jest, według niego, związana z rozumieniem samego siebie - posiadaniem wysokiego poziomu samowiedzy i mądrości; druga zaś odnosi się do rozumienia relacji międzyludzkich oraz uczuć, intencji i stanów innych osób (Walters, Gardner, 1985, za: Gardner, Kornhaber, Wake, 2001). Tym, co nowe w koncepcji Gardnera było to, że włączył w zakres inteligencji wiele czynników wpływających na efektywność działania - wcześniej z nią nie kojarzonych, takich jak np. inteligencja muzyczna czy kinestetyczna oraz, wymienione już, inteligencja intrapersonalna i interpersonalna, przez co znacznie rozszerzył jej zakres znaczeniowy. Stało się to podstawą dla rozwoju studiów nad inteligencją emocjonalną, i stąd właśnie Gardner jest uważany za prekursora powstania terminu inteligencja emocjonalna.

Oprócz samego Gardnera również zwolennicy koncepcji hierarchicznych inteligencji, tacy jak Wechsler (1974, za: Firkowska-Mankiewicz, 1993), czy też Cattell (1971; por. Matczak, 1994), wyrażali pogląd o względnej odrębności różnych typów zdolności. Wechsler postulował, żeby w obręb inteligencji włączyć także czynniki pozaintelektualne takie jak zdolność kontroli emocjonalnej czy wrażliwość społeczna, co znalazło wyraz we wprowadzeniu przez niego do skal mierzących inteligencję testów zdolności społecznych: Rozumienie i Historyjki (Campell, McCord, 1996; por. Matczak, Piekarska, Studniarek, 2005). Także Cattell w ramach inteligencji skrystalizowanej wyszczególnił zdolności społeczne (por. Piotrowska, 1988).

Samo sformułowanie „inteligencja emocjonalna” pojawiło się w literaturze w latach 60. XX w., użyte przez Leunera - niemieckiego psychiatrę i psychonanalityka - w artykule pt. Inteligencja emocjonalna i emancypacja (Leuner, 1966, za: Śmieja, Orzechowski, 2008). W artykule tym wspomniany autor podejmował kwestię inteligencji emocjonalnej w odniesieniu do nieradzenia sobie kobiet z pełnieniem ról społecznych. Ich trudności według niego były spowodowane utratą bezpiecznego przywiązania i zbyt szybką separacją od matek, co z kolei miało skutkować nierozwinięciem się u nich inteligencji emocjonalnej. O ile samo spostrzeżenie Leunera, że 
nieprawidłowości pojawiające się w relacji z matką w okresie wczesnego dzieciństwa mogą wpłynąć negatywnie na rozwój inteligencji emocjonalnej można uznać za bardzo cenne, o tyle remedium na ten problem, proponowane przez niego w postaci psychoterapii połączonej z podawaniem LSD25, można uznać za pomysł nie tylko ekstrawagancki, lecz także szkodliwy. Być może jednak w czasach Leunera, kiedy hippisowska kultura „dzieci kwiatów” sugerowała sięganie po różne środki w celu osiągnięcia wyższych stanów świadomości, a szkodliwe skutki zażywania LSD nie były jeszcze dogłębnie zbadane i poznane od strony medycznej, taki środek mógł być potraktowany w duchu tamtejszej kultury jako dobra droga do zjednoczenia podzielonej - w tym przypadku w wyniku traumy wczesnodziecięcej - jaźni.

Badania empiryczne prowadzone na przestrzeni wielu lat dowiodły, że tradycyjnie pojmowana inteligencja nie obejmuje wszystkich właściwości intelektu ludzkiego oraz nie potwierdziły w pełni zależności pomiędzy inteligencją a efektywnością działania (Ledzińska, 1999). Można wnioskować, że funkcjonowanie inteligencji jest zjawiskiem dynamicznym, tylko po części poznawczym (Nęcka, 1994). U schyłku zeszłego stulecia pojęcie inteligencji emocjonalnej doczekało się naukowego sprecyzowania. Stało się to za sprawą Saloveya i Mayera (1990), którzy podali definicję oraz opisali strukturę tej inteligencji. To dzięki nim inteligencja emocjonalna weszła „na salony” nauki i została wprowadzona do psychologii. Jednak tym, który pojęcie to rozreklamował szerokiej publiczności, był Goleman (1995; wyd. polskie: 1997, 1999). Dzięki jego książkom na ten temat inteligencja emocjonalna zdobyła rozgłos oraz zainteresowanie na całym świecie nie tylko wśród badaczy i praktyków, ale także dziennikarzy, dzięki czemu zagościła w świadomości przeciętnego czytelnika. Być może popularność inteligencji emocjonalnej, rozumianej tak, jak przedstawiał to Goleman, wzięła się między innymi stąd, że dzięki umiejętnej „sprzedaży” i promocji tego pojęcia, zaczęła się ona przeciętnemu odbiorcy jawić jako klucz nie tylko do sukcesu zawodowego, ale także do szczęścia czy życiowego spełnienia w ogóle, jako warunek konieczny rozwoju i realizacji potencjału osobowego jednostki. Jeśli do tego dodać, że inteligencja emocjonalna przedstawiana była w opozycji do klasycznie rozumianej inteligencji, której dominująca wartość predyktywna w odniesieniu do sukcesu i powodzenia życiowego została podważona (np. Felsman, Vaillant, 1987, za: Goleman, 1997; Terman, Oden, 1959, za: Strelau, 1997) oraz że Goleman przedstawiał ją jako coś, co można 
trenować, rozwijać i udoskonalać, to pojęcie to nie mogło nie zrobić furory. Inteligencja emocjonalna stała się „bohaterką” licznych artykułów w prasie, programów telewizyjnych i poradników (np. Cooper, Sawaf, 2000; Shapiro, 1999; Wilks, 1999).

Przy okazji warto nadmienić, że w Polsce pojawiła się pokrewna pojęciu inteligencji emocjonalnej koncepcja inteligencji intuicyjnej, będąca próbą połączenia pojęć inteligencji i stylów myślenia (m.in. Dobrołowicz, 1995, 2001, 2002; Dudek, 2002; Karwowski, 2006). Gdyby spróbować te pojęcia porównać, choćby ze względu na ich zakres znaczeniowy, to inteligencja emocjonalna byłaby tu, moim zdaniem, pojęciem szerszym. Inteligencję intuicyjną możemy odnieść jedynie do intuicyjnego stylu myślenia, natomiast przy „posługiwaniu się” inteligencją emocjonalną korzystamy zarówno $\mathrm{z}$ intuicyjnego, jak i racjonalnego stylu myślenia.

W dalszej części monografii refleksji poddane zostaje rozumienie konstruktu, jakim jest inteligencja emocjonalna. Przyjrzymy się w niej różnym spojrzeniom na ten temat, mającym wyraz w konkurencyjnych modelach inteligencji emocjonalnej.

\subsection{Sposoby rozumienia inteligencji emocjonalnej}

Nie istnieje obecnie jedna obowiązująca definicja inteligencji emocjonalnej, czy też jeden model wyjaśniający jej strukturę i funkcje. Taki stan rzeczy nie dziwi, zważywszy na fakt, iż do dzisiaj nie ma wypracowanego jednoznacznego stanowiska badaczy co do wielu ważnych pojęć z dziedziny psychologii. Jako przykład można podać chociażby (traktowaną czasem jako opozycyjną w stosunku do inteligencji emocjonalnej; Bar-On, 1997) inteligencję w rozumieniu klasycznym, w odniesieniu do której powstało co najmniej kilkadziesiąt definicji (np. Binet, 1916; Galton, 1921; Matczak, 1994; Spearman, 1927, za: Nęcka, 2003; Stern, 1921; Strelau, 1987, 1997).

Inteligencję emocjonalną często przedstawia się w sposób komplementarny do inteligencji akademickiej, co znajduje wyraz w używaniu wskaźnika EQ na określenie jej poziomu (Emotional Quotient) w odróżnieniu od ilorazu inteligencji IQ (Intelligence Quotient), będącego wskaźnikiem określającym poziom inteligencji „poznawczej”. „Rozbierając” termin „inteligencja emocjonalna” na „części pierwsze”, trzeba byłoby najpierw zdefiniować pojęcia „inteligencja” i „emocje”. 
Jedna ze współczesnych roboczych definicji inteligencji, która w trafny i syntetyczny sposób ujmuje jej istotę, określa ją jako „zdolność przystosowania się do okoliczności dzięki dostrzeganiu abstrakcyjnych relacji, korzystaniu z uprzednich doświadczeń i skutecznej kontroli nad własnymi procesami poznawczymi” (Nęcka, 2002, s. 726). Z kolei spośród różnych wyjaśnień pojęcia „emocje” przytoczę następujące: „Emocje są subiektywnymi stanami psychicznymi, które uruchamiają priorytet dla związanych z nimi programów działania. Ich odczuwaniu towarzyszą zazwyczaj zmiany somatyczne, ekspresje mimiczne i pantomimiczne oraz zachowania" (Doliński, 2002a, s. 322).

Istnieje spór pomiędzy badaczami dotyczący również kwestii, czy pierwszeństwo w występowaniu mają emocje czy poznanie. Niektórzy, jak np. Zajonc (1980), uważają, że to procesy emocjonalne wyprzedzają poznanie; inni są przekonani o zależności odwrotnej (np. Lazarus, 1984; por. Doliński, 2002b). Współcześnie coraz częściej jednak wysuwa się tezę o współzależności emocji i poznania (np. Kolańczyk, 1997). Wiedza na temat intelektu i emocji przeszła długą drogę od koncepcji uznających te pojęcia za rozdzielne lub sprzeczne aż po teorie integrujące, które podkreślają współdziałanie emocji i poznania. Można uznać, że pojęcie inteligencji emocjonalnej jest próbą połączenia tych dwóch wymiarów funkcjonowania człowieka: poznawczego i emocjonalnego. Świadczy o tym wypowiedź jednego z jej badaczy:

Inteligencja emocjonalna powstaje w wyniku owocnego związku systemu poznawczego i emocjonalnego. System poznawczy przeprowadza abstrakcyjne rozumowanie dotyczące emocji, zaś system emocjonalny podwyższa zdolności poznawcze. Ściślej rzecz biorąc, jednostka obdarzona wysoką inteligencją emocjonalną, z jednej strony, posiada umiejętność postrzegania, rozumienia i zarządzania emocjami, z drugiej zaś, emocje wspomagają u niej myślenie (Mayer, 2001, s. 131).

Prowadzone od ponad 30 lat badania i rozważania teoretyczne sprawiają, że rozumienie konstruktu, jakim jest inteligencja emocjonalna, ciągle ewoluuje. Przyjrzyjmy się zatem głównym sposobom rozumienia inteligencji emocjonalnej, które znajdują wyraz w „modelu zdolnościowym” (ability model; Mayer, Salovey, 1999; Mayer, Salovey, Caruso, 2004; Salovey, Mayer, 
1990) oraz „modelach mieszanych” (mixed models; Bar-On, 1997; Boyatzis, Goleman, 2007; Goleman, 1997, 1999; Petrides, Furnham, 2001, 2003).

1.2.1. Inteligencja emocjonalna jako zbiór zdolności. Model zdolnościowy inteligencji emocjonalnej jest tak nazywany przez niektórych autorów (Jasielska, Leopold, 2000; Jaworowska, Matczak, 2008; Knopp, 2006), gdyż traktuje inteligencję emocjonalną jako zbiór zdolności intelektualnych. Model ten jest konsekwentnie reprezentowany przez Saloveya i Mayera, którzy w 1990 roku podali definicję inteligencji emocjonalnej, opis jej struktury oraz propozycję jej pomiaru (Mayer, Di Paolo, Salovey, 1990; Salovey, Mayer, 1990), a w kolejnych latach poddali swój model rewizji (Mayer, Salovey, 1999). Zaproponowany przez nich model inteligencji emocjonalnej jest w największym stopniu spójny z użytym - na określenie zdolności emocjonalnych - terminem „inteligencja” i równoprawny klasycznie pojmowanej inteligencji akademickiej. Według cytowanych autorów inteligencja emocjonalna jest grupą zdolności do przetwarzania informacji emocjonalnych oraz ich używania do celów adaptacyjnych.

Autorzy ci podkreślają poznawczy charakter tychże zdolności i ich związek z inteligencją klasyczną, przy jednoczesnej specyfice używanego materiału, który ma charakter emocjonalny. Właśnie owa specyfika materiału, na którym operują zdolności poznawcze należące do tej grupy, odróżnia tę inteligencję od innych rodzajów inteligencji. Informacje emocjonalne stanowią rodzaj informacji behawioralnych rozumianych zgodnie z koncepcją Guilforda (1978). Salovey i Mayer (1990), w proponowanym przez siebie modelu zdolnościowym inteligencji emocjonalnej (ability model), umiejętnie łączą ze sobą dwa, wydawałoby się odmienne, a nawet przez niektórych uważane za przeciwstawne, komponenty: poznawczy i afektywny, starając się wiernie trzymać pierwotnego znaczenia zarówno pojęcia „inteligencji”, jak i pojęcia „emocji”, co zapewnia mu pewną konsekwencję i elegancję terminologiczną, i niejako uprawomocnia, już na poziomie teoretycznym, zasadność używania określenia „inteligencja emocjonalna” wobec opisywanego przez nich konstruktu.

W modelu zdolnościowym w skład inteligencji emocjonalnej wchodzą następujące poziomy zdolności i należące do nich podkategorie (zaczynając od najprostszych - wcześniejszych rozwojowo, po bardziej złożone - późniejsze rozwojowo): 
Pierwszy poziom percepcji, oceny i ekspresji emocji dotyczy zdolności identyfikowania emocji u siebie i u innych, adekwatnej ekspresji emocjonalnej, rozróżniania szczerych i nieszczerych, adekwatnych i nieadekwatnych przekazów emocjonalnych.

Drugi poziom, jakim jest emocjonalne wspomaganie myślenia, obejmuje: zdolność wykorzystywania emocji do sterowania swoją uwagą w kierunku tego, co istotne; emocjonalne wspomaganie pamięci i oceny; zdolność do wykorzystywania nastroju w celu przyjęcia różnych punktów widzenia - od perspektywy pesymistycznej do optymistycznej; zdolność do wspierania stanami emocjonalnymi procesu skutecznego rozwiązywania problemów (np. radość sprzyja myśleniu twórczemu i indukcyjnemu).

Trzeci poziom to wykorzystywanie wiedzy emocjonalnej, czyli zdolności do: rozumienia i nazywania emocji; interpretacji znaczeniowej emocji w kontekście społecznym (np. zrozumienia, że smutek pojawia się na skutek straty); rozumienia emocji złożonych i przewidywania prawdopodobnych sekwencji emocjonalnych.

Czwarty poziom z kolei to świadoma regulacja emocji obejmująca takie zdolności jak: zdolność do otwartości na różnorodne uczucia (zarówno przyjemne, jak i nieprzyjemne); zdolność do świadomego włączania lub ignorowania emocji w zależności od oceny ich użyteczności; zdolność do świadomej kontroli emocji własnych i cudzych; zdolność do refleksyjnej kontroli emocji w odniesieniu do siebie i do innych poprzez wyciszanie emocji negatywnych i wzmacnianie pozytywnych, bez tłumienia lub przeceniania informacji, które mogą ze sobą nieść (por. Maruszewski, Ścigała, 1998; Mayer, Salovey, 1999; Mayer i in., 2004).

Wyżej wymienione zdolności są przedstawione jako cztery gałęzie funkcjonowania, które - jak wcześniej była mowa - są ułożone hierarchicznie od najprostszego poziomu percepcji i ekspresji emocji, aż po najbardziej złożony poziom świadomej kontroli i regulacji emocji. Autorzy przyjmują założenie, że w rozwoju inteligencji emocjonalnej przechodzi się kolejno od pierwszej gałęzi zdolności po ostatnią, a więc, że pojawienie się bardziej złożonych zdolności i klas umiejętności emocjonalnych bazuje na posiadanych zdolnościach emocjonalnych prostszego typu i jest przez nie warunkowane. Proces rozwoju inteligencji emocjonalnej jest zapoczątkowany uczeniem się rozpoznawania własnych i cudzych emocji i przebiega aż po osiągnięcie świadomej regulacji stanów emocjonalnych. Zatem np. możemy 
rozumieć i analizować emocje (gałąź trzecia), jeśli posiadamy zdolność ich prawidłowego identyfikowania (gałąź pierwsza), a nie na odwrót. Proces ten przebiega przez całe życie i wymaga zaangażowania i pracy jednostki (Mayer, Salovey, Caruso, 2000a).

1.2.2. Inteligencja emocjonalna jako zbiór cech osobowości. Kolejnym sposobem rozumienia inteligencji emocjonalnej jest traktowanie jej jako zbioru cech osobowości, które sprzyjają dobremu przystosowaniu w sytuacjach zadaniowych i społecznych. Głównym reprezentantem tego stanowiska jest Bar-On (1997, 2000), który definiuje inteligencję emocjonalną jako zbiór pozapoznawczych kompetencji, umiejętności i zdolności, dzięki którym jednostka może efektywnie radzić sobie z wymaganiami i presjami ze strony środowiska. Autor nie nazywa składowych swojego modelu cechami osobowości, lecz zdolnościami, mimo że, de facto, większość z nich to cechy osobowości.

Sam Bar-On często używa określenia Emotional Quotient (EQ; por. Szczygieł, 2006), podkreślając w ten sposób równoległość inteligencji emocjonalnej w stosunku do inteligencji akademickiej, której poziom określa się ilorazem inteligencji (IQ, Intelligence Quotient; por. Firkowska-Mankiewicz, 1993; Ledzińska, 2001; Matczak, 2001a). Bar-On (1997) w swojej koncepcji wyróżnił pięć grup czynników, które składają się na inteligencję emocjonalną. Są to:

- komponenty intrapersonalne: emocjonalna samoświadomość, asertywność, szacunek dla siebie, samo aktualizacja, niezależność;

- komponenty interpersonalne: empatia, zdolność do nawiązywania i utrzymywania satysfakcjonujących relacji interpersonalnych, odpowiedzialność społeczna;

- komponenty adaptacyjne: zdolność rozwiązywania problemów, zdolność do konfrontowania subiektywnego doświadczenia z obiektywną rzeczywistością, elastyczność adaptacyjna;

- komponenty radzenia sobie ze stresem: tolerancja na stres, kontrola impulsów;

- komponenty ogólnego tonusu emocjonalnego: poczucie szczęścia i optymizm. 
Analiza czynnikowa danych uzyskanych przy użyciu stworzonego przez Bar-Ona kwestionariusza (Emotional Quotient Inventory; Bar-On, 2000) umożliwiła wyodrębnienie dziesięciu składników podstawowych i pięciu „wspomagających”. Podstawowe to: zdolność do utrzymywania więzi interpersonalnych, kontrola impulsów, zdolność rozwiązywania problemów, emocjonalna samoświadomość, giętkość, zdolność konfrontowania subiektywnych doświadczeń z obiektywną rzeczywistością, tolerancja na stres, asertywność i empatia; wspomagające to: optymizm, samoaktualizacja, poczucie szczęścia, niezależność i odpowiedzialność społeczna. Wśród wymienianych przez Bar-Ona składników inteligencji emocjonalnej część należy do kompetencji (np. zdolność do podtrzymywania więzi, kontrola impulsów), stąd model ten jest nazywany modelem mieszanym.

Takie podejście uznają też inni badacze, np. Petrides i Furnham (Wytykowska, Petrides, 2007), którzy wyróżniają takie składowe inteligencji emocjonalnej, które mają charakter cech osobowości, np. empatia, łatwość adaptacji, asertywność, umiejętność spostrzegania emocji, ich wyrażania oraz kontroli, umiejętność wpływania na stany emocjonalne innych ludzi, niska impulsywność, zdolność nawiązywania kontaktów interpersonalnych, poczucie własnej wartości, umiejętność automotywacji, kompetencja społeczna, radzenie sobie ze stresem, poczucie szczęścia i optymizm (Petrides, Furnham, 2001, 2003).

Autorzy ci podkreślają odmienne niż w modelu zdolnościowym rozumienie inteligencji emocjonalnej (por. Neubauer, Freudenthaler, 2005), pisząc, że pojmowana przez nich inteligencja jako grupa cech osobowości warunkuje zachowania typowe (ujawniające się w codziennym funkcjonowaniu jednostki, w przeciwieństwie do inteligencji emocjonalnej rozumianej jako zbiór zdolności, która z kolei warunkuje zachowania maksymalne (ujawniające się w sprzyjających i szczególnie motywujących okolicznościach). W pierwszym przypadku mowa o inteligencji emocjonalnej jako dyspozycji motywacyjnej, zaś w drugim - jako dyspozycji instrumentalnej (Matczak, 2006).

1.2.3. Inteligencja emocjonalna jako zbiór kompetencji. Inteligencja emocjonalna jest też rozumiana jako zbiór kompetencji czy umiejętności. Są badacze, którzy zwracają uwagę na fakt, że zdolności emocjonalne nie są tożsame z kompetencjami emocjonalnymi (Matczak, Knopp, 2013). 
Zdolności określają sprawność procesów poznawczych, które umożliwiają nabywanie umiejętności ważnych dla efektywnego funkcjonowania człowieka, natomiast kompetencje są już opanowanymi umiejętnościami radzenia sobie w różnych sytuacjach. Zdolności są zatem czynnikiem poznawczym warunkującym nabywanie kompetencji, choć kompetencje zależą też od innych czynników pozapoznawczych.

Jednym z przedstawicieli stanowiska ujmującego inteligencję emocjonalną jako kategorię bardzo pojemną mieszczącą w sobie zarówno cechy, jak i kompetencje, a nawet nazywającym ją „charakterem”, jest Goleman. $\mathrm{W}$ jednej ze swoich prac definiuje on inteligencję emocjonalną jako

zdolność do motywacji i wytrwałość w dążeniu do celu mimo niepowodzeń, umiejętność panowania nad popędami i odłożenia na później ich zaspokojenia, regulowania nastroju i niepoddawania się zmartwieniom upośledzającym zdolność myślenia, wczuwania się w nastroje innych osób i optymistycznego patrzenia w przyszłość (Goleman, 1997, s. 67).

W kolejnej swojej książce wymienia następujące obszary inteligencji emocjonalnej: rozumienie emocji (dostrzeganie uczuć, kierowanie swoimi emocjami), zarządzanie emocjami (manipulowanie emocjami, aby były właściwe, zdolność uspokajania siebie, zdolność do pozbywania się narastającego niepokoju, posępności, irytacji), motywowanie siebie (porządkowanie emocji użytecznych do osiągnięcia celu, odraczanie gratyfikacji i ograniczenie impulsywności, gotowość do ulegania zmiennym nastrojom), rozpoznawanie cudzych emocji (świadomość empatyczna, dostrojenie do tego, czego inni chcą lub potrzebują), podtrzymywanie relacji interpersonalnych (umiejętność zarządzania emocjami innych ludzi, łatwość interakcji z innymi; por. Goleman, 1999). Jego koncepcja sprawia wrażenie traktowania inteligencji emocjonalnej jako definicyjnego „worka”, który pomieści prawie wszystko, co dotyczy walorów funkcjonowania człowieka, z wyjątkiem dyspozycji, które w zbyt oczywisty sposób jednak do niego „nie pasują" (nauka zna już takie przypadki pojęć - „worków”, np. w psychiatrii taki charakter ma koncepcja osobowości borderline, która, chociaż ostatnio znajduje praktyczne wykorzystanie w psychoterapii, początkowo stanowiła wygodne rozwiązanie w przypadku trudności diagnostycznych; por. Jakubik, 2002). Być może to szerokie ujęcie inteligencji emocjonalnej, która jawi 
się w tym kontekście jako kwintesencja zdrowej, zintegrowanej osobowości, czyni to pojęcie atrakcyjnym dla przeciętnego odbiorcy, chociaż jednocześnie może je czynić mniej atrakcyjnym dla badaczy tego obszaru funkcjonowania człowieka, ze względu chociażby na małą precyzyję pojęciową. Goleman postuluje odróżnianie terminów „inteligencja emocjonalna” od terminu „kompetencja emocjonalna”, przedstawiając pierwszą z nich jako „potencjalne zdolności uczenia się umiejętności praktycznych”, zaś drugą jako określającą, „ile z tych potencjalnych zdolności udało się zamienić w umiejętności", jednak nie jest w tym konsekwentny - np. w zmodyfikowanej przez siebie koncepcji inteligencji emocjonalnej używa nazwy „kompetencje" (osobiste, społeczne) do określenia dwóch kategorii składników inteligencji emocjonalnej (Goleman, 1999).

Innym autorem, który traktuje inteligencję emocjonalną jako zbiór kompetencji jest Boyatzis (2009; Boyatzis, Goleman, 2007), wyróżniający w jej obrębie m.in. takie umiejętności jak: samoświadomość emocjonalna, samokontrola emocjonalna, orientacja na osiąganie celów, umiejętność adaptacji, optymistyczne podejście do życia, umiejętność wpływania na innych, umiejętność bycia liderem czy umiejętność rozwiązywania konfliktów oraz współpracy z innymi.

Granica między zdolnościami a kompetencjami nie jest ostra. W praktyce określenie, gdzie mamy jeszcze do czynienia ze zdolnościami, a gdzie już z kompetencjami może być trudne. Kompetencje ukształtowane na bazie zdolności mogą być wiarygodnymi ich wskaźnikami. Stąd niektórzy badacze uznają, że rację bytu - oprócz modelu zdolnościowego - ma również model inteligencji emocjonalnej rozumianej jako zbiór kompetencji (Matczak, Knopp, 2013).

\subsubsection{Inteligencja emocjonalna jako poczucie własnej skuteczno-}

ści. Jeszcze inne - niż wcześniej zaprezentowane - rozumienie inteligencji emocjonalnej proponują tacy badacze jak Petrides i Furnham (2000a, 2001, 2003). Kładą oni większy nacisk na to, jak jednostka subiektywnie ocenia posiadane przez siebie kompetencje wchodzące w skład inteligencji emocjonalnej niż na to, jaki obiektywnie poziom tychże kompetencji sobą reprezentuje. Innymi słowy uważają, że o posiadaniu inteligencji emocjonalnej decyduje przekonanie, że się ją posiada. Tę cechę, czy też dyspozycję, nazywają poczuciem własnej skuteczności emocjonalnej (emotional self-efficacy). Definiują 
oni inteligencję emocjonalną jako układ dyspozycji behawioralnych oraz przekonań dotyczących posiadania zdolności do identyfikowania, przetwarzania i wykorzystywania informacji emocjonalnych (por. Petrides, Pita, Kokkinaki, 2007; Wytykowska, Petrides, 2007).

Ze stanowiskiem o ważności autopercepcji w zakresie posiadanej inteligencji emocjonalnej zdają się zgadzać też inni badacze (np. Matczak, 2007a), pisząc o tym, że u osób, które nawet obiektywnie posiadają zdolności emocjonalne, lecz nie mają do nich zaufania, inteligencja emocjonalna nie będzie się wiązała $\mathrm{z}$ efektywnością funkcjonowania. Tak więc, co ciekawe, reprezentanci tego modelu akcentują ważność pozytywnej samooceny, nawet jeśli jest ona nieadekwatna.

O pojęciu samoskuteczności w odniesieniu do funkcjonowania emocjonalnego człowieka pisze także Saarni (1997; wyd. pol. 1999). Odnosi je ona bardziej do pojęcia kompetencji emocjonalnej niż do inteligencji emocjonalnej. Dzięki poczuciu własnej skuteczności w obszarze emocji osoba doświadcza adekwatności własnego doświadczania emocji i ich ekspresji w odniesieniu do danego kontekstu sytuacyjnego, co sugerowałoby subiektywność jednostkowych standardów tego, co jest uznawane za kompetentne, a co nie. Przy tym kontekst sytuacyjny oznacza również kontekst kulturowy, który wpływa na odmienność oczekiwań społecznych np. odnośnie do ekspresji emocji w zależności od danej kultury (np. Black-Michaud, 1975; Briggs, 1970; Ellsworth, 1994; Harkness, Super, 1985; Triandis, 1994, za: Doliński, 2002c). Jednak sama koncepcja Saarni jest uznawana przez niektórych, pomimo używanego nazewnictwa, za bliższą koncepcji zdolnościowej inteligencji emocjonalnej. Za takim rozumieniem przemawia fakt, że autorka wymienia jako elementy kompetencji społecznej konkretne zdolności: zdolność do identyfikowania emocji innych ludzi, zdolność nazywania emocji i integrowania kulturowych skryptów definiujących związki między emocjami a rolami społecznymi, zdolność do empatii i współbrzmienia z innymi, zdolność do rozumienia strategii autoprezentacyjnych i uświadamiania sobie potencjalnej rozbieżności między wewnętrznym stanem a zewnętrzną jego ekspresją, zdolność do samoregulacji emocjonalnej, dostrzeganie związku między przekazami emocjonalnymi a relacjami międzyludzkimi, zdolność do samoskuteczności emocjonalnej rozumianej również jako samoakceptacja w dziedzinie doświadczanych uczuć (por. Leopold, 2001, 2006). 
Krytycy pojęcia „inteligencji emocjonalnej” wysuwają zarzut (dotyczy on przede wszystkim modeli mieszanych), że jest ono nadużywane w celu określenia czegoś, co już dawno zostało nazwane w inny sposób, i że stanowi nadmierne rozszerzenie pojęcia „inteligencja”, w efekcie rozmywając jego znaczenie. Niemniej głosy krytyczne nie omijają także modelu zdolnościowego (sprawnościowego), zarzucając mu m.in. brak wyjaśnienia mechanizmów czy procesów będących podstawą wymienianych w nim zdolności (Matthews, Zeidner, Roberts, 2002).

Przy rozróżnieniu na odmiennie traktujące inteligencję emocjonalną modele, „jak bumerang” powraca pytanie, czym w istocie jest inteligencja emocjonalna i jakie komponenty się na nią składają oraz który z istniejących modeli jest najbardziej użyteczny. Istnieje pogląd, że inteligencja emocjonalna rozumiana jako zdolność oraz inteligencja emocjonalna rozumiana jako zbiór cech osobowości to jednak dwa odmienne pojęcia, które odnoszą się do dyspozycji różnej natury (Matczak, 2006; Neubauer, Freudenthaler, 2005; Petrides, Furnham, 2001). Niektórzy badacze postulują, że w związku z tym należałoby jednak inaczej je nazywać, wprowadzając pewien porządek terminologiczny (por. Knopp, 2020).

Tu przyjmuję sposób rozumienia inteligencji emocjonalnej traktującej ją jako jako zbiór zdolności poznawczych, który w sposób uzasadniony posługuje się terminem ,inteligencja”. O tym, jak się sytuuje inteligencja emocjonalna w odniesieniu do innych rodzajów inteligencji, będzie mowa w dalszej części pracy.

\subsection{Inteligencja emocjonalna a inne rodzaje inteligencji}

Jeśli świadomie posługujemy się terminem „inteligencja emocjonalna”, to nasuwa się pytanie, jak inteligencja emocjonalna ma się do innych rodzajów inteligencji, a szczególnie do tradycyjnie pojmowanej inteligencji akademickiej, wyrażanej w ilorazie inteligencji, czyli IQ.

Mayer i in. (2000a, s. 400) uważają, że inteligencja emocjonalna „jest faktycznie inteligencją jak inne inteligencje”. Argumentują to tym, iż spełnia ona kryteria dla pojęcia inteligencji: jej składniki można zoperacjonalizować jako zdolności, umiarkowanie koreluje z inteligencją ogólną, wzrasta wraz z wiekiem (Mayer, 2001; Mayer, Caruso, Salovey, 1999; Mayer i in., 2000a; 
Mayer, Salovey, Caruso, Sitarenios, 2001). To, co wspólne dla różnie nazywanych rodzajów inteligencji, to fakt, że pełnią one funkcję adaptacyjną. Tę funkcję posiada również inteligencja emocjonalna. Badacze piszą o niej, że „jak każda inna inteligencja, stanowi wyznacznik efektywności radzenia sobie przez człowieka z wymaganiami życia" (Jaworowska, Matczak, 2008, s. 18). Tym, co różni ją od inteligencji akademickiej, jest „gorący” charakter operacjonalizowanych informacji oraz wiedzy emocjonalnej, która jest jej wyrazem, w przeciwieństwie do "chłodnego" przetwarzania informacji, jakie ma miejsce w przypadku inteligencji tradycyjnie rozumianej.

To implikuje u badaczy kolejne pytanie z tym związane: czy przetwarzanie informacji emocjonalnych wymaga jakościowo innych działań umysłowych, niż ma to miejsce w przypadku przetwarzania informacji o innym charakterze (np. werbalnym, liczbowym etc.; Matczak, Knopp, 2013) Kolejne pytania rodzi próba odniesienia konstruktu inteligencji emocjonalnej do modelu inteligencji Cattella (1971; por. Nęcka, 2003): czy inteligencja emocjonalna jest przejawem inteligencji skrystalizowanej kształtującej się na bazie inteligencji płynnej, czy też może sama składa się zarówno z czynnika płynnego, jak i skrystalizowanego (Matczak, 2004a)? Zdaniem niektórych można w jej obrębie wyróżnić zarówno inteligencję płynną, jak i inteligencję skrystalizowaną (Matczak, 2008).

Dane empiryczne na temat związku inteligencji emocjonalnej z inteligencją akademicką dostarczają informacji na temat niezbyt wysokich, ale istotnych korelacji pomiędzy nimi w przypadku, gdy inteligencja emocjonalna jest mierzona testowo, choć trzeba dodać, że zależność ta nie ujawnia się konsekwentnie we wszystkich badaniach. Na przykład, badania Mayera i in. (1999) ujawniły umiarkowaną korelację $(0,36)$ pomiędzy inteligencją emocjonalną (mierzoną MEIS) a inteligencją werbalną (mierzoną testem słownikowym ze skali Army Alpha). Najbardziej związany ze zdolnościami werbalnymi okazał się tu czynnik rozumienia emocji $(0,40)$ oraz kolejno: czynnik kierowania emocjami $(0,20)$ i czynnik spostrzegania emocji $(0,16)$. Inni badacze, tacy jak Mayer i Geher (1996), uzyskali w swoich badaniach związek dodatni $(0,26)$ pomiędzy trafnością rozpoznawania emocji a inteligencją mierzoną testem uzdolnień szkolnych SAT.

Trzeba jednak dodać, że zależność między inteligencją emocjonalną a inteligencją ogólną nie ujawnia się konsekwentnie we wszystkich badaniach. Na przykład, u Daviesa, Stankova i Robertsa (1998) wyniki 
testu wymagającego rozpoznawania emocji korelowały wybiórczo z jedną z użytych miar inteligencji płynnej $(0,24)$ oraz dwiema miarami inteligencji skrystalizowanej $(0,25$ i 0,21$)$, ale generalnie ich badania nie potwierdziły związku pomiędzy zdolnością do spostrzegania emocji a inteligencją płynną i skrystalizowaną. Także Ciarrochi, Chan i Caputi (2000) nie otrzymali istotnego statystycznie związku pomiędzy inteligencją emocjonalną (MEIS) a inteligencją płynną mierzoną Testem matryc Ravena. Jaworowska i Matczak (2008) w swoich badaniach uzyskały słaby, ale istotny związek inteligencji emocjonalnej ze zdolnościami do rozumowania abstrakcyjnego (Kwestionariusz inteligencji emocjonalnej INTE oraz Test matryc Ravena, Bateria testów APIS-Z, Test sortowania kart $z$ Wisconsin i Test OMNIBUS).

Pytanie o relację między inteligencją emocjonalną a innymi rodzajami inteligencji wiąże się też z ogólniejszym pytaniem: gdzie należałoby ulokować inteligencję emocjonalną w strukturze intelektu? Odpowiedź na to pytanie będzie zależna od tego, jaką koncepcję struktury intelektu przyjmiemy.

Zwolennicy hierarchicznego ujmowania inteligencji klasycznej mogą się skłaniać do ujmowania inteligencji emocjonalnej jako jednego z czynników specyficznych, nasyconego w pewnym stopniu czynnikiem ogólnym $g$, będącym ogólnym potencjałem intelektualnym przejawiającym się w poszczególnych zdolnościach. Argumentem na to, iż tacy autorzy jak Salovey i Mayer uznają najprawdopodobniej budowę hierarchiczną inteligencji emocjonalnej jest to, że zakładają oni pewną stopniowalność poziomów jej rozwoju, gdzie kolejne piętra zdolności powstają w toku rozwoju na bazie pięter niższego rzędu i gdzie poszczególne zdolności wchodzące w skład każdego z poziomów zdolności również są przez nich przedstawiane w kolejności określającej kolejność ich pojawiania się w toku dojrzewania emocjonalnego jednostki.

Można by zatem przychylać się do twierdzenia, mającego odniesienie do koncepcji inteligencji Cattella, że na inteligencję emocjonalną składa się potencjał inteligencji płynnej, który inwestowany w toku rozwoju emocjonalnego jednostki przejawia się i konkretyzuje się jako poszczególne zdolności składające się na inteligencję skrystalizowaną. Za tym może też przemawiać kwestia, iż inteligencja emocjonalna jest silnie uwarunkowana wpływem środowiska rodzinnego i oddziaływań wychowawczych z jednej strony, z drugiej zaś - aktywnością własną jednostki, co mogłoby wskazywać na to, że potencjał „płynny” inteligencji emocjonalnej, chociaż jest 
warunkiem startowym/bazą dla jej rozwoju, jednak może być mniej lub bardziej wykorzystany czy rozwijany w zależności od układu czynników wewnętrznych i zewnętrznych kształtujących człowieka. Potencjał też może być „unieruchomiony” poprzez np. wydarzenia traumatyczne w okresie wczesnego dzieciństwa czy też późniejszym, które mogą spowodować odcięcie osoby od emocji zlokalizowanych w ciele, a zatem od materiału, którego obróbka jest warunkiem rozwoju inteligencji emocjonalnej.

Badania empiryczne dotyczące ewaluacji konstruktu inteligencji emocjonalnej mierzonej przy pomocy wielowymiarowej skali inteligencji emocjonalnej (Multifactor Emotional Intelligence Scale, MEIS; Ciarrochi i in., 2000) potwierdziły istnienie emocjonalnego $g$ przenikającego wszystkie podskale wchodzące w skład opisywanego narzędzia. Istnienie ogólnego czynnika inteligencji emocjonalnej wykazały też analizy przeprowadzone przez innych badaczy (Mayer i in., 1999; Palmer, Gignac, Manocha, Stough, 2005), co wskazywałoby na strukturę hierarchiczną inteligencji emocjonalnej. Wyżej wspomniane wyniki badań przeprowadzonych przy użyciu takich narzędzi jak np. wielowymiarowa skala inteligencji emocjonalnej (MEIS) i test inteligencji emocjonalnej Mayera, Saloveya i Caruso (Mayer-Salovey-Caruso Emotional Intelligence Test, MSCEIT; Mayer, Salovey, Caruso, 2002) skutkowały wnioskiem o czteroczynnikowej (Mayer, Salovey, Caruso, Sitarenios, 2003; Śmieja, Orzechowski, Beauvale, 2007), trójczynnikowej (Mayer i in., 1999) lub też dwuczynnikowej (Ciarrochi i in., 2000) jej budowie. W badaniach Mayera, Caruso i Saloveya ujawniły się trzy czynniki wchodzące w skład inteligencji emocjonalnej: zdolność do spostrzegania emocji, zdolność do rozumienia ich i zdolność do kierowania nimi. Ciarrochi i in. (2000) wyróżnili w obrębie inteligencji emocjonalnej dwa czynniki: percepcję emocjonalną, odpowiadającą zdolnościom do spostrzegania i wyrażania emocji (pierwszy poziom w modelu Saloveya i Mayera) oraz emocjonalne rozumienie i kierowanie (drugi, trzeci i czwarty poziom w modelu Saloveya i Mayera, odpowiadający gałęziom asymilacji emocji, rozumienia i kontroli).

Ze stanowiskiem lokującym inteligencję emocjonalną w koncepcjach hierarchicznych inteligencji nie zgadzają się niektórzy badacze (np. Bar-On, 1997), którzy są skłonni negować istnienie czynnika $g$, co prowadzi do konkluzji, że w ich mniemaniu inteligencja emocjonalna i inteligencja ogólna są od siebie niezależne (Jaworowska, Matczak, 2008). 
Zwolennicy modelu czynników równorzędnych inteligencji (Gardner, 1983; Gardner i in., 2001), który zakłada niezależność zdolności składających się na inteligencję i, tym samym, brak czynnika g, zapewne będą skłonni widzieć ją jako jedną z wielu inteligencji czy też zdolności istniejących niezależnie. Na przykład - jak była już o tym mowa - Gardner (1983) wyróżnił, obok innych rodzajów inteligencji (np. logiczno-matematycznej, muzycznej, werbalnej), także inteligencję intrapersonalną i interpersonalną, które wchodzą w skład inteligencji emocjonalnej. Mogłoby to sugerować w konsekwencji przypuszczenie, że zdolności składające się na inteligencję emocjonalną mają charakter autonomicznych, niezależnych od siebie czynników.

Goleman (1999) stwierdza wręcz, że obie grupy zdolności: inteligencja emocjonalna i inteligencja akademicka mogą niekiedy być wobec siebie przeciwstawne, co argumentuje tym, że wysoki poziom inteligencji klasycznej skutkuje czasem zaangażowaniem w rozstrzyganie problemów teoretyczno-technicznych przy jednoczesnym zaniedbaniu aktywności rozwijających społeczno-emocjonalnie, czego konsekwencją jest niski poziom inteligencji emocjonalnej.

Inteligencja emocjonalna wydaje się być jednym ze składników intelektu; zarazem jednak sama w sobie stanowi złożony konstrukt, a dane empiryczne zdają się wskazywać, że tak jak nie istnieje jedna inteligencja - lecz wiele zdolności intelektualnych, tak też nie istnieje jedna inteligencja emocjonalna - lecz wiele zdolności emocjonalnych (Matczak, 2006).

$\mathrm{W}$ dalszej części książki przyjrzymy się różnym typom inteligencji emocjonalnej. Intraindywidualne zróżnicowanie zdolności ma miejsce nie tylko w przypadku zdolności wchodzących w skład klasycznie pojmowanej inteligencji, ale odnosi się również do zdolności emocjonalnych. Innymi słowy, zdolności inteligencji emocjonalnej mogą układać się w różne kombinacje, a tym samym - różnicować jednostki pod względem profilu inteligencji emocjonalnej.

\subsection{Typy inteligencji emocjonalnej}

Analizy profilowe przemawiają za istnieniem pewnych typów inteligencji emocjonalnej. Mamy tu do czynienia, o czym była mowa wcześniej, z intraindywidualnym zróżnicowaniem zdolności emocjonalnych - osoby 
reprezentujące określony typ inteligencji emocjonalnej charakteryzują się wyższym poziomem pewnych zdolności w porównaniu $\mathrm{z}$ innymi.

\subsubsection{Inteligencja emocjonalna interpersonalna vs. intraperso-}

nalna. W literaturze można spotkać się z określeniem „intrapersonalnej inteligencji emocjonalnej", a więc zdolności emocjonalnych odnoszących się do własnej osoby, oraz z określeniem „interpersonalnej inteligencji emocjonalnej” odnoszącej się do funkcjonowania w relacjach z innymi ludźmi (Bar-On, 2000; Matczak, Jaworowska, 2006; Neubauer, Freudenthaler, 2005).

Salovey i Mayer (1990; por. Neubauer, Freudenthaler, 2005) w swoim pierwotnie trójskładnikowym modelu inteligencji emocjonalnej uznali, że dwa z wymienionych składników występują w odniesieniu do „ja” oraz w odniesieniu do innych, a więc na inteligencję emocjonalną składają się między innymi: zdolność oceny i ekspresji emocji u siebie (werbalna i niewerbalna) i u innych (niewerbalna percepcja i empatia) oraz regulacja emocji u siebie i u innych; trzeci zaś składnik odnosi się tylko do funkcjonowania intrapersonalnego i zawiera takie elementy jak zdolności do wykorzystywania emocji jako czynników facylitujących elastyczność, myślenie kreatywne, giętkość uwagi i samomotywowanie się do działania (Matczak, 2008). Z kolei w zmodyfikowanym, bardziej rozbudowanym, modelu inteligencji emocjonalnej (Mayer, Salovey, 1997) można zauważyć elementy emocjonalnej inteligencji intrapersonalnej i interpersonalnej na pierwszym, trzecim i czwartym poziomie (zdolność identyfikowania emocji u siebie i u innych, zdolność do ich ekspresji oraz rozróżniania u innych niespójnej ekspresji emocji, zdolność rozumienia i analizowania emocji własnych i cudzych, zdolność refleksyjnej regulacji emocji: ich monitorowania zarówno u siebie, jak u innych oraz zarządzania nimi w sobie i u innych), podczas gdy poziom drugi reprezentuje wyłącznie zdolności intrapersonalne (zdolności emocjonalnej facylitacji myślenia).

W modelach mieszanych również można zauważyć wyróżnianie przez autorów (explicite lub implicite) komponentów inteligencji emocjonalnej wyraźnie intrapersonalnych oraz zdecydowanie interpersonalnych. $\mathrm{Na}$ przykład, nieco późniejsza definicja inteligencji emocjonalnej przedstawiona przez Golemana w jego drugiej książce na ten temat (1999) zawiera rozróżnienie na kompetencje osobiste (samoświadomość, samoregulacja, automotywowanie się do działania) oraz kompetencje społeczne (empatia, 
umiejętności społeczne). Również w koncepcji Bar-Ona pojawia się rozróżnienie na komponenty intra- i interpersonalne inteligencji emocjonalnej, które stanowią u niego dwa z pięciu elementarnych składników inteligencji emocjonalnej. W tabeli 1 przedstawione zostało zestawienie komponentów intrapersonalnych i interpersonalnych inteligencji emocjonalnej w zależności od modelu, w jakim jest ujmowana.

Tabela 1

Zestawienie składników intra- $i$ interpersonalnych $w$ różnych modelach inteligencji emocjonalnej

\begin{tabular}{|c|c|c|}
\hline Autorzy & Intrapersonalne komponenty & Interpersonalne komponenty \\
\hline \multirow{4}{*}{$\begin{array}{l}\text { Salovey, } \\
\text { Mayer } \\
(1990)\end{array}$} & Percepcja własnych emocji & Percepcja cudzych emocji \\
\hline & Asymilacja emocji & Rozumienie cudzych emocji \\
\hline & Rozumienie własnych emocji & \multirow{2}{*}{$\begin{array}{l}\text { Kontrola i regulacja } \\
\text { emocji u innych }\end{array}$} \\
\hline & $\begin{array}{l}\text { Samokontrola i samoregulacja } \\
\text { emocjonalna }\end{array}$ & \\
\hline \multirow{3}{*}{$\begin{array}{l}\text { Goleman } \\
\text { (1997) }\end{array}$} & Samoświadomość & Empatia \\
\hline & Samoregulacja & \multirow{2}{*}{$\begin{array}{l}\text { Umiejętność wzbudzania } \\
\text { pożądanych reakcji } \\
\text { u innych osób }\end{array}$} \\
\hline & Motywowanie się do działania & \\
\hline \multirow{6}{*}{$\begin{array}{l}\text { Bar-On } \\
(1997)\end{array}$} & Samoświadomość & \multirow{3}{*}{$\begin{array}{l}\text { Empatia } \\
\text { Zdolność do utrzymywania } \\
\text { więzi społecznych }\end{array}$} \\
\hline & emocjonalna & \\
\hline & Asertywność & \\
\hline & $\begin{array}{l}\text { Samoakceptacja } \\
\text { i szacunek do siebie }\end{array}$ & \multirow[t]{3}{*}{ Odpowiedzialność społeczna } \\
\hline & Samoaktualizacja & \\
\hline & Niezależność & \\
\hline
\end{tabular}

Ciąg dalszy tabeli na następnej stronie 


\begin{tabular}{|c|c|c|}
\hline Autorzy & Intrapersonalne komponenty & Interpersonalne komponenty \\
\hline $\begin{array}{l}\text { Petrides, } \\
\text { Furnham } \\
(2001)\end{array}$ & $\begin{array}{l}\text { Asertywność } \\
\text { Niska impulsywność } \\
\text { Poczucie własnej wartości } \\
\text { Umiejętność motywowania się } \\
\text { Umiejętność radzenia sobie } \\
\text { ze stresem } \\
\text { Poczucie szczęścia } \\
\text { Optymizm } \\
\text { Umiejętność dostrzegania } \\
\text { emocji, ich wyrażania } \\
\text { i kontrolowania }\end{array}$ & $\begin{array}{l}\text { Umiejętność wpływania } \\
\text { na stany emocjonalne } \\
\text { innych ludzi } \\
\text { Zdolność nawiązywania relacji } \\
\text { interpersonalnych } \\
\text { Empatia } \\
\text { Społeczna kompetencja }\end{array}$ \\
\hline $\begin{array}{l}\text { Saarni } \\
(1999)^{*}\end{array}$ & $\begin{array}{l}\text { Samoregulacja emocjonalna } \\
\text { Poczucie samoskuteczności } \\
\text { emocjonalnej, czyli akceptacja } \\
\text { własnych uczuć }\end{array}$ & $\begin{array}{l}\text { Zdolność do spostrzegania } \\
\text { emocji u innych osób } \\
\text { Zdolność do empatycznego } \\
\text { współgrania z innymi } \\
\text { Zdolność do rozumienia } \\
\text { strategii autoprezentacyjnych } \\
\text { i uświadamiania sobie } \\
\text { rozbieżności między stanem } \\
\text { wewnętrznym a zewnętrznym } \\
\text { ich wyrazem }\end{array}$ \\
\hline
\end{tabular}

* uwzględniono w niej także koncepcję C. Saarni, która, choć deklaratywnie odnosi się do kompetencji emocjonalnej, to jednak wydaje się odpowiadać rozumieniu inteligencji emocjonalnej.

W kontekście poruszanego tematu warto dodać, że analiza czynnikowa polskiego narzędzia DINEMO (Dwuwymiarowy Inwentarz Inteligencji Emocjonalnej) do pomiaru inteligencji emocjonalnej wyodrębniła dwa czynniki: zdolności emocjonalne odnoszące się emocji własnych oraz zdolności emocjonalne odnoszące się do emocji innych ludzi (Matczak, Jaworowska, 2006).

1.4.2. Inteligencja emocjonalna poznawcza vs. działaniowa. Innej jeszcze możliwości klasyfikacji komponentów inteligencji emocjonalnej dostarczyły niektóre dane empiryczne (Matczak, 2006, 2008), sugerujące 
możliwość wyróżnienia w jej obrębie czynnika poznawczego i działaniowego. Na pierwszy z nich składają się zdolność rozpoznawania oraz zdolność rozumienia emocji (odpowiadające pierwszej i trzeciej grupie zdolności wyróżnionych w modelu Saloveya i Mayera), na drugi zaś - zdolność do kierowania się emocjami i świadomego ich wykorzystania w działaniu (lokalizujące się w grupie drugiej i czwartej modelu tychże autorów; Salovey, Mayer, 1999).

Za odrębnością tych dwóch podkategorii inteligencji emocjonalnej przemawiają dane empiryczne. I tak, wykazują one np., że tylko składnik poznawczy koreluje dodatnio ze zdolnością rozumienia emocji mierzoną za pomocą testów. Z kolei aspekt działaniowy wyróżniony w analizach dokonanych za pomocą testu MEIS (Mayer, Salovey, Caruso, 1997) i MSCEIT (Mayer i in., 2002), jako zdolność do regulacji emocji, jest czynnikiem najmniej „nasyconym poznawczo”, łączącym w sobie składowe emocjonalne, poznawcze i motywacyjne, których połączenie stanowi rodzaj pomostu pomiędzy intelektem a osobowością. Działaniowy obszar inteligencji emocjonalnej kształtuje się („krystalizuje”) i rozwija dzięki aktywności społecznej i zadaniowej jednostki, zaś jej obszar poznawczy - dzięki aktywności intelektualnej.

Rozróżnienie na czynnik poznawczy i działaniowy nabiera też innego sensu w zależności od rodzaju zastosowanego pomiaru - kwestionariuszowego lub testowego. W ramach kwestionariuszy czynnik poznawczy jest wyrażany w pytaniach dotyczących rozumienia emocji i rozwiązywania problemów z nimi związanych na poziomie teoretycznym, zaś czynnik działaniowy - przez pytania dotyczące praktycznego radzenia sobie w sytuacjach emotogennych (można tu dostrzec opozycję potencjalnych zdolności i rzeczywistych umiejętności). W testach czynnik poznawczy oznacza zdolność rozumienia, oceny i prognozowania sytuacji emocjonalnych, a czynnik działaniowy - zdolność do budowania skutecznych strategii działania w sytuacjach emocjonalnych, co niekoniecznie oznacza umiejętność ich zastosowania w życiu (por. Matczak, 2006).

1.4.3. Inteligencja emocjonalna doświadczeniowa vs. strategiczna. W modelu zdolnościowym inteligencji emocjonalnej niektóre jej składowe są ze sobą „spokrewnione”: zdolność do percepcji emocji oraz zdolność do asymilacji emocji są nazywane doświadczeniową (experiential) 
inteligencją emocjonalną, zaś zdolność do rozumienia emocji oraz zdolność do regulacji emocji są nazywane strategiczną (strategical) inteligencją emocjonalną (por. Ciarrochi i in., 2000). Inteligencja doświadczeniowa jest zdolnością bycia w kontakcie z emocjami poprzez dostrzeganie ich, akceptowanie i spójne z nimi postępowanie (z niesionym przez nie przekazem). $Z$ kolei strategiczna inteligencja emocjonalna związana jest $\mathrm{z}$ intelektualnym podejściem do emocji, ich poznawczą kontrolą i regulacją - umożliwia zatem refleksję i kontrolę nad doświadczeniowym aspektem inteligencji emocjonalnej.

Odrębność tych dwóch rodzajów inteligencji emocjonalnej potwierdzają analizy czynnikowe wyników testu MSCEIT (Mayer i in., 2002; por. Bracket, Salovey, 2008). Korelacje pomiędzy tymi dwoma rodzajami inteligencji są niewielkie i wynoszą 0,28 u O'Connora i Little’a (2003), zaś 0,46 w badaniach Bracketta, Mayera i Warnera (2004). Inteligencja emocjonalna strategiczna wykazuje silniejszy związek ze zdolnościami poznawczymi.

Istnieją również polskie badania przeprowadzone za pomocą PKIE (Jaworowska, Matczak, 2005) przemawiające za zasadnością wyodrębnienia podziału inteligencji emocjonalnej na doświadczeniową i strategiczną. Dane uzyskane z tych badań świadczą o tym, że najwyżej korelują ze sobą akceptowanie emocji i empatia oraz kontrola i skala rozumienia emocji. Najniżej zaś korelują akceptacja z rozumieniem emocji. Taki układ związków sugeruje podobieństwo konstruktów mierzonych przez skale akceptowania i empatii oraz skale kontroli i rozumienia. Skala akceptowania mierzy akceptowanie, wyrażanie i wykorzystywanie własnych emocji w działaniu, zaś skala empatii mierzy poziom empatii, czyli stopień zrozumienia i rozpoznawania emocji u innych ludzi. Obie te skale odpowiadają temu, co określane jest jako doświadczeniowa inteligencja emocjonalna. Pozostałe skale PKIE, czyli skala kontroli przeznaczona do pomiaru kontroli, również poznawczej, nad własnymi emocjami oraz skala rozumienia służąca do pomiaru rozumienia i uświadamiania własnych emocji, odpowiadają strategicznej inteligencji emocjonalnej.

W innych polskich badaniach (Matczak, Knopp, 2019) uzyskano nieco odmienne rezultaty: o ile takie składowe inteligencji emocjonalnej strategicznej jak rozumienie i kontrola emocji okazały się być ze sobą pozytywnie skorelowane, to nie stwierdzono znaczącego związku pomiędzy składowymi inteligencji emocjonalnej doświadczeniowej takimi jak empatia 
a rozpoznawanie i akceptowanie emocji. Co ciekawe, empatia okazała się być tą zdolnością emocjonalną, która najsłabiej koreluje z ogólną inteligencją emocjonalną.

Wielowymiarowość konstruktu inteligencji emocjonalnej jest przedstawiona na rysunku 1. Widzimy, że różne typy inteligencji emocjonalnej krzyżują się ze sobą i przenikają. Zarówno inteligencja emocjonalna doświadczeniowa, jak i strategiczna zawierają element poznawczy, jak i działaniowy. W obrębie tej pierwszej, jednostka potencjalnie wykorzystuje taki komponent poznawczy inteligencji emocjonalnej jak zdolność do spostrzegania emocji oraz taki komponent działaniowy inteligencji emocjonalnej jak zdolność asymilowania emocji w celu wspomagania nimi procesów poznawczych; zaś w obrębie drugiej wymienionej - może korzystać z elementu poznawczego inteligencji emocjonalnej, jakim jest zdolność rozumienia emocji oraz z elementu działaniowego inteligencji emocjonalnej, jakim jest zdolność kontroli i regulacji emocjonalnej.

Chociaż na rysunku nie jest to uwidocznione, warto dodać, że ze wszystkich wymienionych zdolności emocjonalnych trzy odnoszą się zarówno do inteligencji intra- jak i interpersonalnej (percepcja, rozumienie, kontrola emocji). Jedynie asymilacja emocji odnosi się wyłącznie do inteligencji interpersonalnej.

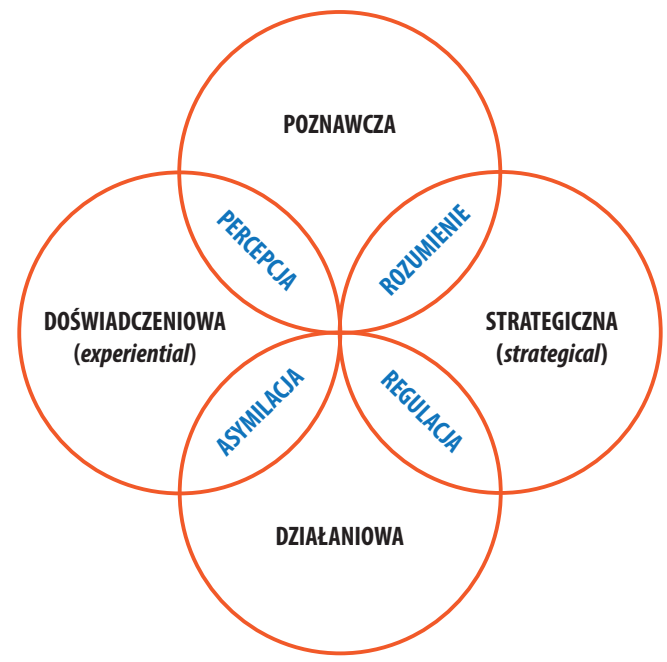

Rysunek 1. Wielowymiarowość inteligencji emocjonalnej uwzględniająca różne jej typy. 


\subsection{Odniesienie inteligencji emocjonalnej do poznawczo-doświadczeniowej teorii osobowości Seymoura Epsteina}

Podział inteligencji emocjonalnej na doświadczeniową i strategiczną można odnieść do poznawczo-doświadczeniowej teorii „ja” Epsteina (Cognitive-Experiential Self Theory, CEST; Epstein, 1992, 2003, 2008, 2014; Epstein, Lipson, Holstein, Huh, 1992; Epstein, Pacini, Denes-Raj, Heier, 1996; Kirkpatrick, Epstein, 1994). Według niej każdy człowiek tworzy własną teorię rzeczywistości obejmującą takie elementy jak teoria "ja” (self theory; np. „ja” jest wartościowe-bezwartościowe), teoria świata (world theory; np. świat jest przyjazny-wrogi) oraz teoria wzajemnej relacji „ja-świat” (np. przekonania o własnej skuteczności czy możliwości modyfikowania świata).

Zgodnie z CEST ludzie przetwarzają informacje w dwóch równoległych, interaktywnych systemach: przedświadomym systemie doświadczeniowym oraz świadomym systemie racjonalnym, które składają się na osobowość jednostki. Atrybuty tych systemów Epstein wyprowadził z rozważań logicznych, porównujących myślenie człowieka w sytuacjach działania emocjonalnego $\mathrm{z}$ jego myśleniem, kiedy nie jest zaangażowany emocjonalnie (Epstein i in., 1992). Obserwacje życia codziennego przedstawiają uwzględniony przez autora podział (Epstein, 1994). Odmienny jest sposób myślenia ludzi przeżywających emocje i niepobudzonych emocjonalnie. Pierwsi, pod wpływem emocji, myślą w sposób kategoryczny, osobisty, konkretny, bezrefleksyjny i zorientowany na działanie. W codziennym życiu ludzie bardzo często przeżywają emocje w wyniku interpretacji zaistniałej sytuacji, a nie w odpowiedzi na faktyczny stan rzeczy. Wskazuje to na odmienny od analitycznego, przedświadomy sposób przetwarzania informacji. Intuicja ludzka sprawia, że zdajemy sobie sprawę z dwóch sposobów poznawania i tego, że kierujemy się „sercem” albo „głową”, często zresztą przeżywając konflikt pomiędzy nimi, który według Epsteina dowodzi konfliktu pomiędzy procesami intuicyjnego wglądu i wiedzą ,intelektualną," odpowiadającymi kolejno doświadczeniowemu i racjonalnemu systemowi. Przykładem szczególnego udziału systemu doświadczeniowego w naszym życiu są narracje, których sporo można odnaleźć w literaturze pięknej, Biblii, mitach. Uczą one poprzez opowiadania i przypowieści, a nie abstrakcyjny dyskurs. Według Epsteina człowiek reaguje żywiej i silniej na przekaz wizualny niż 
werbalny, co zresztą jest wykorzystywane np. w reklamie. Komunikaty w formie obrazów angażują system doświadczeniowy. Ponadto autor uważa, że obecne w codzienności przesądy i przekonania religijne wskazują na przewagę zastosowania systemu doświadczeniowego nad racjonalnym.

Systemy racjonalny i doświadczeniowy działają według różnych zasad (Denes-Raj, Epstein, 1994). Ten pierwszy jest refleksyjny, rozważny, analityczny, głównie werbalny, świadomy i znajdujący wyraz w funkcjonowaniu według konwencjonalnych, ustalonych reguł wnioskowania. Dostrzega on powiązania przyczynowo-skutkowe. Jest bardziej zorientowany na proces, zintegrowany, doświadczany świadomie i aktywnie: człowiek pozostaje w nim pod kontrolą własnych myśli. Cechuje się większym zróżnicowaniem, myśleniem wielowymiarowym. Zachowanie w wyniku działania tego systemu jest zapośredniczone przez świadomą ocenę zdarzeń. Na poziomie tego systemu rzeczywistość jest kodowana w abstrakcyjnych symbolach, takich jak słowa i liczby, co wymaga wysiłku i koncentracji.

Stwierdzenie Epsteina, że kodowanie rzeczywistości na poziomie systemu doświadczeniowego za pomocą metafor i opowiadań jest szybkie i łatwe, w przeciwieństwie do kodowania na poziomie systemu racjonalnego za pomocą symboli i słów, może jednak budzić wątpliwości. Wynikają one z tego, iż metafory już z założenia są czymś abstrakcyjnym i oderwanym od konkretu oraz symbolicznym w odniesieniu do kultury. Opowiadania zaś często posiadają strukturę, która nie jest dokładną kopią struktury opisywanych wydarzeń.

System racjonalny jest wolniejszy i bardziej wymagający od systemu doświadczeniowego, a przez to mniej użyteczny i rzadziej używany do kierowania większością codziennych zachowań człowieka. Bardziej nadaje się do odroczonych akcji i złożonych, obiektywnych, beznamiętnych analiz (Epstein, 2014).

Natomiast system doświadczeniowy jest impulsywny, przedświadomy, intuicyjny, szybki, skojarzeniowy i holistyczny. W sposób automatyczny dokonuje on interpretacji, dekodowania i organizacji doświadczenia oraz ukierunkowania zachowania. W porównaniu z systemem racjonalnym, jest bardziej „niedojrzały”, szybciej i bardziej powierzchownie ocenia i reaguje na otoczenie. Odpowiada on zdarzeniom w formie konkretnych wzorców; jest kształtowany przez znaczące emocjonalnie doświadczenia z przeszłości. Ważniejsze od powiązań przyczynowo-skutkowych są w nim związki 
skojarzeniowe. Zachowanie w wyniku jego działania jest zapośredniczone przez odbicia przeszłych doświadczeń. Koduje on rzeczywistość w obrazach, metaforach i opowiadaniach i jest zorganizowany w tzw. moduły poznawczo-afektywne. Człowiek jest pod jego wpływem „porywany” przez emocje. System ten podlega autoweryfikacji przez doświadczenie. Jest najbardziej adekwatny i przydatny do zastosowania w szybkiej ocenie informacji i w ostatecznych (decydujących) akcjach. Na poziomie tego systemu ujawnia się ogromna adaptacyjna funkcja informacyjna emocji, które są w nim drogą "na skróty” w sytuacjach wymagających szybkiej oceny, w których emocje są źródłem informacji pewnych i błyskawicznych.

Według Epsteina to właśnie przetwarzanie informacji na poziomie systemu doświadczeniowego, a nie racjonalnego, jest standardową, automatyczną opcją, która determinuje codzienne zachowanie. Pomimo to ludzie, kiedy są do tego odpowiednio zmotywowani, są w stanie przestawić się na bardziej analityczny, logiczny tryb myślenia na poziomie systemu racjonalnego. Zatem zachowanie człowieka najczęściej pozostaje pod wpływem obu tych systemów (zestawienie porównawcze ich charakterystyk przedstawia tabela 2).

Epstein i współpracownicy (Epstein i in., 1996), opisując myślenie charakterystyczne dla obu systemów, nawiązują do różnych teorii. I tak, wymieniają oni następujące określenia sposobu przetwarzania informacji w systemie doświadczeniowym: intuicyjne (Jung), naturalne (Tversky i Kahneman), automatyczne (Bargh i Higgins), heurystyczne (Chaiken, Fiske, Taylor oraz Tversky i Kahneman), schematyczne (Leventhal), prototypowe (Rosch), narracyjne (Bruner), utajone (Weinberger i McClelland), wyobrażeniowo-niewerbalne (Bucci i Paivio), mityczne (mythos; Labouvie-Vief) i pierwszosygnałowe (Pawłow). Z drugiej zaś strony określają myślenie analityczno-racjonalne jako: pojęciowo-logiczne (Leventhal-Jung), dyskursywne-intencjonalne - wymagające wysiłku - systemowe (Bargh, Chaiken i Higgins), jawne (Weinberger i McClelland), rozciągłe (Tversky i Kahneman), werbalne (Bucci i Paivio), racjonalne (logos; Labouvie-Vief), właściwe drugiemu układowi sygnałowemu (Pawłow).

W odniesieniu do stylów poznawczych bezpośredni system regulacji (doświadczeniowy) charakteryzuje konkretność, duża potrzeba domknięcia poznawczego i impulsywność, zaś pośredni system regulacji (racjonalny) cechuje abstrakcyjność, mała potrzeba domknięcia poznawczego i refleksyjność (Szydłowski, 2019). 
Istnienie systemów doświadczeniowego i racjonalnego, inaczej mówiąc: dwóch sposobów przetwarzania informacji, znalazło potwierdzenie w badaniach empirycznych (np. Denes-Raj, Epstein, 1994; Epstein i in., 1996; Evans, 2008, 2010; Evans, Stanovich, 2013a, 2013b; Kirkpatrick, Epstein, 1992). Działanie systemu doświadczeniowego było wyraźniej obserwowane w sytuacjach, w których ludzie byli konfrontowani z rzeczywistymi doświadczeniami o dużym ładunku emocjonalnym oraz wtedy, gdy warunki udaremniały zaspokojenie ich potrzeby autoprezentacji jako osoby racjonalnej (Epstein, 1994). W badaniach okazało się np., że osoby częściej korzystające z systemu doświadczeniowego częściej też posługują się heurystykami w wydawaniu sądów od osób, które wykazywały przewagę $\mathrm{w}$ wykorzystywaniu systemu racjonalnego i preferowały normatywny model podejmowania decyzji (Epstein i in., 1996).

\section{Tabela 2}

Zestawienie porównawcze charakterystyk dwóch głównych systemów przetwarzania informacji w CEST (ttumaczenie własne; por. Epstein, 2003)

\begin{tabular}{cc}
\hline System doświadczeniowy & System racjonalny \\
\hline Całościowy & Analityczny \\
\hline Emocjonalny & Logiczny \\
\hline $\begin{array}{c}\text { Połączenia na zasadzie skojarzeń } \\
\text { Orientacja na cel }\end{array}$ & $\begin{array}{c}\text { Połączenie według zasady: } \\
\text { przyczyna-skutek }\end{array}$ \\
\hline $\begin{array}{c}\text { Zachowanie jest modyfikowane } \\
\text { przez aurę/klimat doświadczeń } \\
\text { z przeszłości }\end{array}$ & $\begin{array}{c}\text { Orientacja na proces } \\
\text { przez świadomą ocenę zdarzeń }\end{array}$ \\
\hline $\begin{array}{c}\text { Kodowanie rzeczywistości } \\
\text { metafor i narracji }\end{array}$ & $\begin{array}{c}\text { Kodowanie rzeczywistości w formie } \\
\text { abstrakcyjnych symboli, słów i liczb }\end{array}$ \\
\hline
\end{tabular}




\begin{tabular}{|c|c|}
\hline System doświadczeniowy & System racjonalny \\
\hline $\begin{array}{l}\text { Szybsze przetwarzanie zorientowa- } \\
\text { ne na natychmiastowe działanie }\end{array}$ & $\begin{array}{l}\text { Wolniejsze przetwarzanie } \\
\text { zorientowane na odległe działanie }\end{array}$ \\
\hline $\begin{array}{l}\text { Zmiana zachodzi wolno; kluczem } \\
\text { do niej jest powtarzalność } \\
\text { i intensywność doświadczeń }\end{array}$ & $\begin{array}{c}\text { Zmiana zachodzi gwałtownie; } \\
\text { kluczem do niej jest szybkość my- } \\
\text { ślenia }\end{array}$ \\
\hline $\begin{array}{c}\text { Mniej } \\
\text { zróżnicowany/wysublimowany } \\
\text { (myślenie kategoryczne) }\end{array}$ & $\begin{array}{c}\text { Bardziej zróżnicowany/wysublimo- } \\
\text { wany (myślenie wielopłaszczyzno- } \\
\text { we) }\end{array}$ \\
\hline $\begin{array}{l}\text { Mniej zintegrowany: dysocjacyjny, } \\
\text { częściowo zorganizowany } \\
\text { w kompleksy emocjonalne } \\
\text { (poznawczo-afektywne moduły) }\end{array}$ & Bardziej zintegrowany \\
\hline $\begin{array}{l}\text { Doświadczany pasywnie } \\
\text { i przedświadomie; w nim jesteśmy } \\
\text { „pochwyceni” przez emocje }\end{array}$ & $\begin{array}{l}\text { Doświadczany aktywnie i świado- } \\
\text { mie; w nim jesteśmy kontrolowani } \\
\text { przez myśli }\end{array}$ \\
\hline $\begin{array}{c}\text { Samosprawdzalność wiarygodności: } \\
\text { „doświadczyć to uwierzyć” }\end{array}$ & $\begin{array}{l}\text { Wymaga uzasadnienia poprzez } \\
\text { logikę i dowody }\end{array}$ \\
\hline
\end{tabular}

Kolańczyk (1999) pisze o dwóch systemach wymienionych przez Epsteina, jako dwóch systemach regulacji zachowania: systemie bezpośredniej regulacji zachowania oraz systemie pośredniej regulacji zachowania. Funkcje każdego $\mathrm{z}$ nich są realizowane w odniesieniu do odmiennych standardów regulacji i związanych z nimi potrzeb oraz wartościowania. Te względnie niezależne systemy regulacji zachowania sterują aktywnością człowieka w różnych kierunkach. Przy tym większość czynności może być sterowana przez oba systemy, co jest zresztą najbardziej adaptacyjną opcją dla człowieka, ponieważ każdy z nich ma swoje zalety i wady.

Jak sądzę, dwa komponenty inteligencji emocjonalnej, jakimi są składniki: doświadczeniowy oraz strategiczny, zawierają się w osobnych systemach wyróżnionych przez Epsteina: inteligencja emocjonalna doświadczeniowa przynależy do systemu doświadczeniowego, zaś inteligencja emocjonalna 
strategiczna - do systemu racjonalnego. Jednym $\mathrm{z}$ argumentów przemawiających za słusznością tego przyporządkowania jest to, że zdolności wchodząc w skład inteligencji emocjonalnej doświadczeniowej są uznawane przez Saloveya i Mayera za wcześniejsze rozwojowo w stosunku do zdolności wchodzących w skład inteligencji emocjonalnej strategicznej, zaś u Epsteina system doświadczeniowy jest pierwotniejszy, wcześniejszy $\mathrm{w}$ stosunku do systemu racjonalnego.

W tym kontekście można by ująć doświadczeniową inteligencję emocjonalną jako intuicyjną, nieświadomą (przedświadomą), pierwotną, związaną z byciem „w emocjach”, z wiedzą "gorącą”, odpowiadającą myśleniu emocjonalnemu. W bezpośrednim systemie przetwarzania to emocje wpływają na nas, a jego funkcjonowanie to m.in. „szybka droga” do wyzwolenia emocji poprzez błyskawiczną percepcję sytuacji. Zdolność do zauważania emocji na poziomie tego systemu warunkuje odbiór wielu ważnych dla działania informacji, także tych, których odbiór „kanałem racjonalnym” jest znacznie opóźniony lub w ogóle niemożliwy. Ukierunkowane nimi reakcje są bardzo często najtrafniejszymi wyborami, optymalnymi w sytuacjach, w których nie ma czasu lub zapotrzebowania na racjonalne rozważanie, stąd znamionująca doświadczeniową inteligencję emocjonalną otwartość na przeżywane emocje jest uważana m.in. za podstawę intuicji (por. Matczak, 2007b).

Strategiczną inteligencję emocjonalną można by, w opozycji do doświadczeniowej, ująć w związku z pośrednim systemem przetwarzania jako umiejętność podejmowania świadomej refleksji nad emocjami, myślenia o nich, wpływania na nie (a nie odwrotnie - jak w poprzednim systemie). W systemie pośredniego przetwarzania do wyzwolenia emocji prowadzi „wolna droga” poprzez refleksję myślową.

Ponieważ dwa wyróżnione systemy przetwarzania informacji, czy szerzej rzecz ujmując - systemy regulacji zachowania/osobowości, są niezależne, można wyróżnić cztery typy ludzi: osoby, które często i efektywnie korzystają zarówno z jednego, jak i drugiego systemu (typ wysoko racjonalny/ wysoko intuicyjny); osoby, które rzadko i/lub mało efektywnie korzystają z jednego i drugiego (typ nisko racjonalny/nisko intuicyjny); osoby, które częściej i efektywniej korzystają z przetwarzania informacji w jednym systemie, przy dużo rzadszym korzystaniu z systemu przeciwnego, a więc albo preferują sposób funkcjonowania wysoko racjonalny/nisko intuicyjny, albo - sposób nisko racjonalny/wysoko intuicyjny. 
Oczywiście najbardziej przystosowawczy sposób funkcjonowania zakłada korzystanie w dużej mierze zarówno z jednego, jak i z drugiego systemu, w zależności od kontekstu sytuacyjnego, ilości posiadanego czasu czy informacji etc. Jak się wydaje, zmienną decydującą jest tutaj elastyczność w przechodzeniu z jednego systemu do drugiego, ponieważ nie możemy jednocześnie „być w obu naraz”, np. „będąc w emocjach”, niejako „porwani” przez nie, nie będziemy jednocześnie racjonalnie nad nimi reflektować, zaś w momencie rozpoczęcia świadomej refleksji myślowej automatycznie zostaje „osłabiona” siła emocji, która jeszcze tuż przed „przełączeniem” na system racjonalny miała na nas dominujący wpływ. Przykładem z życia świadczącym o ważności dobrego funkcjonowania na obu poziomach dla niektórych zawodów są np. zdolności emocjonalne niezbędne do wykonywania zawodu psychoterapeuty: $\mathrm{z}$ jednej strony potrzebny jest wysoki poziom empatii, która pozwala zrozumieć klienta i emocjonalnie z nim współbrzmieć, być do niego emocjonalnie dostrojonym, z drugiej zaś - zdolność kontrolowania emocji własnych i cudzych, która sprawia, że terapeuta nie będzie płakał z płaczącym klientem czy razem z nim wyrażał złości lub wściekłości.

Korzystanie z zasobów inteligencji emocjonalnej tylko na poziomie jednego z Epsteinowskich systemów przetwarzania informacji nie byłoby dla jednostki adaptacyjne. Przykładowo, zbytnie „zanurzenie w emocjach”, ich odczuwaniu czy empatycznej syntonii może uniemożliwiać wyciszenie niepożądanych emocji, ich kontrolę i regulację; z drugiej zaś strony zbyt nasilona samokontrola emocjonalna może skutkować stłumieniem, wyparciem emocji, a więc odcięciem od nich, co w efekcie byłoby równoznaczne $z$ utratą niesionych przez emocje informacji (Mayer i in., 2002).

Wyniki analizy skupień potwierdziły dwuczynnikowy model inteligencji emocjonalnej (Ciarrochi i in., 2000), wykazując istnienie osób o wysokiej doświadczeniowej inteligencji emocjonalnej oraz osób o wysokiej strategicznej inteligencji emocjonalnej (Jaworowska, Matczak, 2005). Analiza skupień w badaniach przeprowadzonych za pomocą Popularnego kwestionariusza inteligencji emocjonalnej (PKIE; Jaworowska, Matczak, 2005) pozwoliła na wyodrębnienie czterech profili inteligencji emocjonalnej charakteryzujących badanych: WIE - wysokiej inteligencji emocjonalnej we wszystkich skalach, PIE - przeciętnej inteligencji emocjonalnej we wszystkich skalach, DOŚW - wysokich wyników w skalach doświadczeniowej 
inteligencji emocjonalnej (akceptowanie, empatia) przy znacznie niższych wynikach w pozostałych (kontrola, rozumienie), STR - wysokich wyników w skalach odpowiadających strategicznej inteligencji emocjonalnej (kontrola, rozumienie) przy znacznie niższych wynikach w skalach akceptowania i empatii. Badania na podstawie tego narzędzia wykazały istotne korelacje między czynnikami kontroli i rozumienia emocji, a więc zdolnościami będącymi elementami inteligencji strategicznej, oraz wysokie korelacje między akceptacją, wyrażaniem i wykorzystywaniem własnych emocji a empatią, a więc zdolnościami inteligencji doświadczeniowej, co również potwierdza słuszność wyodrębnienia tych podzakresów inteligencji emocjonalnej.

Można tu dostrzec analogię do wyników, jakie przyniosły badania Epsteina i współpracowników w odniesieniu do systemów przetwarzania informacji i profilów przez niego uzyskanych. I tak, można by wysunąć przypuszczenie, że osoby wysoko racjonalne/wysoko intuicyjne być może są właśnie osobami o wysokiej inteligencji emocjonalnej na obu poziomach - doświadczeniowym i strategicznym (WIE), osoby nisko racjonalne/nisko intuicyjne są osobami o przeciętnej inteligencji emocjonalnej (PIE), osoby nisko racjonalne/wysoko intuicyjne są osobami o wysokiej doświadczeniowej inteligencji emocjonalnej (DOŚW), a osoby wysoko racjonalne/nisko intuicyjne - osobami o wysokiej inteligencji strategicznej (STR). Przy tym należy pamiętać, że skoro rozwinięcie inteligencji strategicznej jest uwarunkowane posiadaniem zdolności z poziomu inteligencji doświadczeniowej, zatem zapewne u danej osoby musi zaistnieć jakaś wartość progowa tej drugiej, która gwarantowałaby bazę rozwoju pierwszej. Być może zatem istnieje wiele wzorców inteligencji emocjonalnej, które powstają w wyniku różnych układów intraindywidualnie zróżnicowanych zdolności, które się na tę inteligencję składają (Matczak, 2008). Obserwowane powszechnie intraindywidualne zróżnicowanie zdolności wchodzących w obręb klasycznie rozumianej inteligencji (Matczak, 1987) dotyczyłoby zatem również zdolności, z których „zbudowana” jest inteligencja emocjonalna.

Po raz kolejny wraca tu kwestia elastyczności w korzystaniu z zasobów obu rodzajów inteligencji emocjonalnej, czy też - rozszerzając to na koncepcję Epsteina - z obu systemów. Być może „to właśnie umiejętność wybierania odpowiednich strategii - ich elastycznego dostosowywania do rodzaju zadań z jednej strony, a własnych możliwości z drugiej - jest szczególnie istotnym warunkiem efektywności działania i oznaką osób inteligentnych" 
(por. Matczak, 2001a, s. 159). I choć autorka pisze to w odniesieniu do inteligencji ogólnej i stylów poznawczych, to wydaje się, że owa elastyczność funkcjonowania ma istotne zastosowanie również przy odniesieniu inteligencji emocjonalnej do systemów przetwarzania informacji w ujęciu Epsteina. Tę tezę potwierdzałaby też wiedza na temat aleksytymii, często przeciwstawianej inteligencji emocjonalnej (czy też będącej skrajnym przejawem jej deficytu). Aleksytymicy są uważani za osoby, których funkcjonowanie poznawcze cechuje się bardzo małą elastycznością, wywołując u nich trudność w przypadku znalezienia się w sytuacjach odbiegających od standardowych (por. Maruszewski, Ścigała, 1997); występuje też u nich przewaga emocji negatywnych, która nasila kontrolę hamując „wolność do intuicyjnego i giętkiego przetwarzania informacji” (Kolańczyk, Świerzyński, 1995, s. 283).

Odniesienia (implicite) do obu tych systemów można by się doszukiwać również w jednej z definicji inteligencji emocjonalnej podanej przez Mayera:

Inteligencja emocjonalna powstaje w wyniku owocnego związku systemu poznawczego i emocjonalnego. System poznawczy przeprowadza abstrakcyjne rozumowanie dotyczące emocji, zaś system emocjonalny podwyższa zdolności poznawcze. Ściślej rzecz biorąc, jednostka obdarzona wysoką inteligencją emocjonalną, z jednej strony posiada umiejętność postrzegania, rozumienia i zarządzania emocjami, z drugiej zaś, emocje wspomagają u niej myślenie (Mayer, 2001, s. 131).

Istnieją badania sugerujące, że w ramach szerokiej konceptualizacji inteligencja emocjonalna może zawierać dwa różne składniki: jeden powiązany z rozumowaniem wyższego rzędu, uzależnionym od nabytej wiedzy o emocjach, uwarunkowanej kulturowo (inteligencja skrystalizowana; Farrelly, Austin, 2007; Mayer, Roberts, Barsade, 2008) oraz drugi oparty na oddolnych reakcjach sensoryczno-motorycznych w odpowiedzi na informacje emocjonalne, wymagające szybszego przetwarzania (inteligencja płynna; Fiori, Antonakis, 2011), co nasuwa nieodparte skojarzenie z dwoma systemami Epsteina.

Także Goleman pisze: 
Dwa umysły, emocjonalny i racjonalny, działają na ogół w ścisłej harmonii, łącząc swoje zupełnie odmienne sposoby poznawania rzeczywistości we wspólnym zadaniu prowadzenia przez świat i życie. Zazwyczaj pomiędzy umysłem emocjonalnym a umysłem racjonalnym panuje równowaga, emocje dostarczają informacji umysłowi racjonalnemu, wspomagając go tym samym w jego działaniach, umysł racjonalny natomiast analizuje i niekiedy odrzuca dane umysłu emocjonalnego. Mimo to oba są na poły niezależnymi władzami, z których każda (...) odzwierciedla działanie innych, aczkolwiek wzajemnie powiązanych połączeń mózgowych (Goleman, 1997, s. 32).

Takie podejście autora zdaje się podkreślać komplementarność obu systemów przetwarzania informacji oraz ważność harmonijnego korzystania z możliwości każdego z nich.

\subsection{Inteligencja emocjonalna a wiedza emocjonalna deklaratywna vs. proceduralna}

Jednym z przejawów, czy może raczej składowych, inteligencji emocjonalnej jest wiedza emocjonalna. Twórcą pojęcia „wiedza emocjonalna” jest Izard (1971; por. Matczak, 2008). Mianem tym określił on wiedzę kształtującą się od początku życia na bazie doświadczeń emocjonalnych, które są stopniowo włączane do systemu poznawczego człowieka. Wiedza ta rozwija się na różnych poziomach: od wiedzy na temat związku między wydarzeniami i stanami emocjonalnymi a ekspresją emocji oraz ich etykietami werbalnymi, poprzez wiedzę na temat przyczyn emocji, ich skutków oraz sposobów regulacji, aż po wiedzę na temat społecznych standardów i oczekiwań odnośnie do wyrażania emocji (Izard, 2001).

Część autorów, w tym cytowany już wcześniej Izard, uważa, że pojęcie wiedzy emocjonalnej powinno zastąpić pojęcie inteligencji emocjonalnej, gdyż bardziej adekwatnie określa uwarunkowania efektywności przystosowawczych funkcji emocji. Matczak zaś uznaje, że stosunek inteligencji emocjonalnej do wiedzy emocjonalnej można określić następująco: inteligencja emocjonalna jest zdolnością do przetwarzania informacji emocjonalnych, choć są badacze, którzy uważają, że przetwarzanie informacji emocjonalnych jest tylko jednym z komponentów inteligencji emocjonalnej (Fiori, 
Shagini, Vesely-Maillefer, 2019), zaś wiedza emocjonalna jest zbiorem tych informacji, materiałem, którym operuje i na którym działa inteligencja emocjonalna. Inteligencja emocjonalna jest czynnikiem odpowiedzialnym za jakość przyswajania wiedzy emocjonalnej, zaś wiedza emocjonalna jednym ze wskaźników poziomu inteligencji emocjonalnej. W tym kontekście inteligencja emocjonalna jawi się jako relatywnie stała dyspozycja do nabywania w dużym stopniu modyfikowalnej wiedzy emocjonalnej. Takie rozróżnienie przywołuje skojarzenia inteligencji emocjonalnej z inteligencją płynną (warunkującą nabywanie zdolności skrystalizowanych), zaś wiedzy emocjonalnej $-\mathrm{z}$ inteligencją skrystalizowaną.

W literaturze pisze się o szczególnym charakterze wiedzy emocjonalnej, która $\mathrm{w}$ większym stopniu jest uważana za proceduralną, niż za deklaratywną. I choć „może się ona stać przedmiotem refleksji, to znaczna jej część ma charakter niezwerbalizowany, a nawet nieświadomy; jest wiedzą wysoce zindywidualizowaną o charakterze doświadczeniowym - odkrywaną samodzielnie, a nie otrzymywaną w gotowej postaci” (Matczak, 2008).

Podział wiedzy emocjonalnej na wiedzę proceduralną (niedeklaratywną) i deklaratywną można by odnieść do poznawczo-doświadczeniowej teorii osobowości Epsteina (więcej na jej temat piszę w dalszej części pracy). Jednocześnie jednak pojawia się wątpliwość, czy nie byłoby zbytnim uproszczeniem, gdybyśmy emocjonalną wiedzę nieświadomą identyfikowali z doświadczeniową inteligencją emocjonalną, zaś emocjonalną wiedzę świadomą - ze strategiczną inteligencją emocjonalną, choć takie odniesienie do systemów przetwarzania bezpośredniego i pośredniego nie wydaje się pozbawione sensu.

Emocje mogą być reprezentowane w trzech kodach: najwcześniej pojawia się kod obrazowy, potem werbalny, a następnie abstrakcyjny (Lane, Schwartz, 1987; Maruszewski, Ścigała, 1997, 1998; Mayer, Salovey, 1999). U Epsteina kodowanie obrazowe zachodzi w bezpośrednim systemie regulacji, zaś kodowanie werbalne i abstrakcyjne - w pośrednim systemie regulacji.

Reprezentacje emocji zakodowane w sposób obrazowy są związane z procesami percepcji emocji oraz prototypowych sytuacji emotogennych, które są zapisane w postaci skryptów. Według Epsteina (2003) doświadczenia emocjonalne z przeszłości zostają zgeneralizowane, stając się podstawą nie tylko przekonań o samym sobie i świecie, ale także niedeklaratywnej 
(proceduralnej) wiedzy emocjonalnej, która z poziomu nieświadomego czy też przedświadomego warunkuje zachowania jednostki. Kierujący się głosem emocji człowiek „często nie zdaje sobie sprawy z tego, co go skłania do wybierania takich czy innych działań, osób, czy miejsc, a unikania innych, lub jakie są podstawy intuicyjnie stosowanych przez niego środków emocjonalnych ułatwiających wykonywanie określonego rodzaju zadań" (Matczak, 2001a, s. 9). Ludzie w sposób niejako automatyczny konstruują ukryte teorie odnoszące się do świata własnego (self), świata zewnętrznego oraz tego, jak się oba mają do siebie (por. Gasiul, 2002). Wiedzę tego typu, nazwijmy ją „gorącą”, przypisać można - odnosząc się do koncepcji Epsteina - jako przynależną do bezpośredniego, doświadczeniowego systemu przetwarzania informacji.

Kodowanie werbalne i abstrakcyjne, jako późniejsze rozwojowo, będą się odnosić do werbalnego nazywania, opisywania i wyrażania emocji oraz tworzenia i reprezentacji bardziej złożonych emocji. Te rodzaje kodowania będą budowały świadomą wiedzę emocjonalną (metawiedzę, czy inaczej mówiąc - wiedzę o emocjach), którą można przypisać jako przynależną do pośredniego - racjonalnego systemu przetwarzania informacji w koncepcji Epsteina. Wiedza ta jest fundamentalna dla świadomej regulacji emocjonalnej i jest wynikiem zintegrowania informacji mających źródło zarówno we własnych doświadczeniach, jak i w obserwacji innych, a także będących dostępnymi na różny sposób „gotowymi” twierdzeniami na temat emocji. W jej skład wchodzą: znajomość terminów określających emocje; znajomość relacji pomiędzy emocjami; wiedza o przejawach emocji; wiedza różnicująca zachowania i formy ekspresji podobne do siebie, choć będące wynikiem różnych emocji; wiedza o przyczynach emocji i ich dynamice; znajomość czynników wywołujących i zmieniających emocje; wiedza o wpływie emocji na skuteczność funkcjonowania oraz znajomość oczekiwań społecznych odnośnie ujawniania emocji (por. Matczak, Piekarska, 2011).

Podsumowując, człowiek, przetwarzając informacje emocjonalne na poziomie systemu doświadczeniowego, będzie korzystał z nieświadomej wiedzy emocjonalnej, zaś przetwarzając informacje emocjonalne na poziomie systemu racjonalnego - ze świadomej wiedzy emocjonalnej. 


\section{Rozdział 2.}

\section{Pomiar inteligencji emocjonalnej}

Sposób rozumienia inteligencji emocjonalnej często determinuje jej sposób operacjonalizacji. Inteligencja emocjonalna rozumiana „zdolnościowo” najczęściej jest operacjonalizowana za pomocą testów, zaś rozumiana w modelach mieszanych - „osobowościowo” jako kompetencja lub jako poczucie własnej skuteczności - za pomocą kwestionariuszy.

\subsection{Pomiar testowy}

Przedstawiciele zdolnościowego modelu inteligencji emocjonalnej są zdecydowanymi zwolennikami testowego jej pomiaru za pomocą zadań, co zresztą wydaje się spójne z przyjętymi przez nich założeniami na jej temat (np. Mayer i in., 2002). Podkreślają oni fakt, iż nie wiemy, czy i na ile sposób postrzegania własnych zdolności emocjonalnych koreluje z ich rzeczywistym posiadaniem - a na samoocenie w tej kwestii bazuje przecież pomiar kwestionariuszowy inteligencji emocjonalnej. Jest to zresztą spójne z dość powszechnym poglądem na ten temat przypisującym pomiar kwestionariuszowy cechom osobowości, zaś testowy - zdolnościom (por. Matczak, 2006; Petrides, Furnham, 2001). Mayer, Salovey i Caruso są twórcami baterii testów do mierzenia inteligencji emocjonalnej jako zbioru zdolności znanej pod nazwą MEIS - Multifactor Emotional Intelligence Scale (Mayer i in., 1997, 1999) występującej w wersji papierowej oraz jej zmodyfikowanej wersji MSCEIT (Mayer i in., 2002; Mayer i in., 2003). Narzędzie to odzwierciedla czteroskładnikowy model inteligencji emocjonalnej (Brackett, Salovey, 2008). Według Saloveya i współpracowników (Mayer i in., 2001, 2003) spełnia ono kryteria testu inteligencji (struktura czynnikowa mająca odniesienie do modelu teoretycznego; cztery grupy zdolności są 
znaczeniowo powiązane z innymi zdolnościami umysłowymi, np. zdolnościami werbalnymi; zdolności inteligencji emocjonalnej rozwijają się wraz z wiekiem, są obiektywnie mierzalne).

Dostępnymi w Polsce narzędziami testowymi do badania inteligencji emocjonalnej są: SIE-T - Skala Inteligencji Emocjonalnej - Twarze (Matczak i in., 2005), TRE - Test Rozumienia Emocji (Matczak, Piekarska, 2011) oraz TIE - Test Inteligencji Emocjonalnej (Śmieja, Orzechowski, 2007).

Testy inteligencji emocjonalnej bazują najczęściej na materiale wizualnym i werbalnym. W przypadku pierwszego są to najczęściej fotografie lub rysunki przedstawiające ludzi. W przypadku drugiego mogą to być słowa określające emocje lub teksty opisujące sytuacje, w których trzeba rozwiązać problemy typu emocjonalnego. Zadania testowe wymagają od badanych głównie rozpoznawania emocji, identyfikowania ich możliwych źródeł oraz znajdowania rozwiązań problemów emocjonalnych. Zadania te są zwykle zamknięte, tzn. badany ma do wyboru potencjalne, gotowe odpowiedzi. $\mathrm{W}$ wielu testach inteligencji emocjonalnej nie tyle należy wybrać jedno poprawne rozwiązanie, co raczej ocenić wartość każdego z proponowanych rozwiązań na kilkustopniowej skali. Tego typu odpowiedzi nie są zatem punktowane zerojedynkowo, lecz oceniane jako mniej lub bardziej adekwatne.

Metody testowe są krytykowane z powodu ich „sztuczności” i oderwania od konkretnej sytuacji życiowej badanego. Zarzuca się im to, że nie uwzględniają one pewnych komponentów inteligencji emocjonalnej (np. zdolności do ekspresji emocji), ich wyniki mogą silnie korelować ze zdolnościami werbalnymi, a ich konstruowanie napotyka również na problem stworzenia jednoznacznego klucza odpowiedzi. Jest to związane z dywergencyjnym charakterem realnych sytuacji życiowych angażujących inteligencję emocjonalną - nie posiadają one jednego, uniwersalnego rozwiązania (Matczak, Knopp, 2013).

\subsection{Pomiar kwestionariuszowy}

Jeśli chodzi o drugą główną grupę metod badawczych w odniesieniu do inteligencji emocjonalnej, to są to metody samoopisowe, czyli kwestionariusze. Niewątpliwą ich zaletą jest to, że w badaniu pozwalają na uwzględnienie takich przejawów inteligencji emocjonalnej, które trudno byłoby zbadać 
za pomocą testów, oraz w sposób bardziej bezpośredni na odniesienie do życiowych doświadczeń ludzi poddanych badaniu (Jaworowska, Matczak, 2008). Dzięki nim uzyskujemy informacje na temat funkcjonowania badanego w realnych sytuacjach życiowych, co pozwala oczekiwać, że kwestionariusze będą miały większą niż testy wartość prognostyczną, pozwalającą na przewidywanie rzeczywistego zachowania badanych. Kwestionariusze są narzędziami bardziej praktycznymi w zastosowaniu niż testy i pozwalają na uwzględnienie wszystkich komponentów inteligencji emocjonalnej (Matczak, Knopp, 2013).

Do najbardziej znanych kwestionariuszy mierzących inteligencję emocjonalną należą: EQ-i - Bar-On Emotional Inventory Quotient (Bar-On, 1997, 2000, 2002); TEIQue - The Trait Emotional Intelligence Questionnaire (Petrides, 2009; Petrides, Furnham, 2003), a w polskiej adaptacji jako Kwestionariusz inteligencji emocjonalnej - Cechy (Wytkowska, Petrides, 2007); SSRI - Schutte Self-Report Inventory, zwany też SREIT - Self-Report Emotional Intelligence Test lub EIS - Emotional Intelligence Scale (Schutte $\mathrm{i}$ in., 1998), w polskiej adaptacji pod nazwą Kwestionariusz inteligencji emocjonalnej INTE (Jaworowska, Matczak, 2001, 2008); TMMS - Trait Meta Mood Scale (Salovey i in., 1995); DINEMO - Dwuwymiarowy inwentarz inteligencji emocjonalnej (Matczak, Jaworowska, 2006) oraz PKIE - Popularny kwestionariusz inteligencji emocjonalnej (Jaworowska, Matczak, 2005), z którego korzystałam w badaniach przedstawionych w tej pracy.

Kwestionariusze do pomiaru inteligencji emocjonalnej składają się z pozycji o charakterze stwierdzeń najczęściej w pierwszej osobie (rzadziej w trzeciej) odnoszących się do jej umiejętności lub preferencji, czyli upodobań i zainteresowań. Odnosząc się do umiejętności badanego, zakładamy, że jeśli jego samoocena jest trafna, to uzyskujemy w ten sposób informacje o jego kompetencjach i zdolnościach. Natomiast poprzez preferencje badamy zdolności emocjonalne pośrednio, wychodząc z założenia, że jeśli ktoś coś preferuje, czyli lubi, to zazwyczaj dlatego, że „jest w tym dobry” i odwrotnie, jeśli ktoś czegoś nie lubi i unika tzn. że przychodzi mu to z trudnością i wypada w tym słabiej.

Jak się mają do siebie różne miary inteligencji emocjonalnej? Na ogół wyniki pomiarów kwestionariuszowych i testowych wykazują istnienie niewielkich lub nieistotnych związków pomiędzy nimi (np. Brackett, Mayer, 2004; Matczak, 2005; Matczak i in., 2005; O’Connor, Little, 2003). 
W polskich badaniach pod kierunkiem Matczak uzyskano dla jednej z badanych grup korelację 0,39 pomiędzy TRE a INTE. Natomiast w przypadku wyników uzyskanych za pomocą różnych kwestionariuszy korelacje pomiędzy nimi mają wysokie współczynniki (np. Austin, Saklofske, Egan, 2005; Matczak, 2006).

Taka zależność pojawia się także w przypadku porównywania wyników uzyskanych na drodze pomiaru testowego, które wykazują wyraźniejszą korelację między sobą niż z miarami kwestionariuszowymi (np. Ciarrochi i in., 2000; Matczak, 2005; Matczak i in., 2005; Mayer i in., 1999; Palmer i in., 2005).

\subsection{Inne rodzaje pomiaru}

Badacze stosują do pomiaru inteligencji emocjonalnej również inne miary niż - nazywane tradycyjnie - typu „papier i ołówek” (innymi słowy - testy i kwestionariusze w wersji papierowej). Są to np. poznawcze metody badania (por. Austin, 2005; Śmieja, Orzechowski, 2008). Mają one najczęściej charakter zadań komputerowych podawanych w warunkach eksperymentalnych, na podstawie których można mierzyć subtelne rożnice w czasach reakcji badanych na prezentowane bodźce. Umożliwiają pomiar takich elementarnych procesów jak np. procesy uwagi, pamięci roboczej (Nęcka, Orzechowski, Szymura, 2006) czy też czas wstępnej analizy percepcyjnej (inspection time). Zwolennicy takiego sposobu pomiaru uważają, że zadania eksperymentalne są trafniejsze i rzetelniejsze niż miary klasyczne, co nie znaczy, że są w stanie całkowicie je zastąpić (por. Śmieja, Orzechowski, 2008). Często korelują one $\mathrm{z}$ inteligencją płynną, a także $\mathrm{z}$ testami inteligencji emocjonalnej (por. Śmieja, Orzechowski, 2008; Śmieja i in., 2007).

Oprócz już wyżej wymienionych miar, zastosowano - do oceny takiego aspektu inteligencji emocjonalnej jak percepcja, ocena i ekspresja emocji - metodę jakościową zwaną analizą transkrypcji (por. Jasielska, 2007). Metoda ta pierwotnie była przeznaczona do oceny wypowiedzi osób aleksytymicznych, opierającej się na tym objawie aleksytymii, jakim jest niezdolność do werbalizacji emocji i polegającej na jakościowej analizie zachowań werbalnych (Jasielska, 2001). W badaniu nad inteligencją emocjonalną Jasielska uzyskała wyniki świadczące o tym, że osoby inteligentne emocjonalnie używają większej liczby słów nasyconych afektywnie oraz, że częściej od osób 
„nieinteligentnych” emocjonalnie odczytują przekaz emocjonalny zawarty w komunikacie symbolicznym, częściej też przewidują emocjonalne skutki dla wydarzenia, którego są obserwatorami.

Badacze nieustannie podejmują próby tworzenia coraz lepszych narzędzi do pomiaru inteligencji emocjonalnej, co wynika z faktu, że dysponujemy coraz większą ilością danych empirycznych potwierdzających predyktywną rolę inteligencji emocjonalnej dla prawidłowego funkcjonowania człowieka, o czym będzie mowa w dalszej części książki. Można snuć przypuszczenia i refleksje na temat adekwatności i trafności różnych narzędzi do pomiaru inteligencji emocjonalnej; jest to temat budzący wiele wątpliwości wśród badaczy. Nadal poszukuje się sposobów trafnego jej pomiaru, gdyż wiele miar inteligencji emocjonalnej posiada bardzo niską rzetelność. 


\section{Rozdział 3.}

\section{Znaczenie inteligencji emocjonalnej w funkcjonowaniu człowieka}

Inteligencja klasyczna zawiodła pokładane w niej nadzieje tych, którzy próbowali upatrywać w niej główny wyznacznik powodzenia i sukcesu życiowego. „Podejrzenie padło” na inteligencję emocjonalną; zaczęto sądzić, że to właśnie ona może wyjaśniać osiągnięcia w karierze zawodowej oraz być predyktorem efektywnego funkcjonowania społecznego. Na przykład, według Golemana, inteligencja emocjonalna odpowiada aż w $80 \%$ za zróżnicowanie indywidualne $\mathrm{w}$ zakresie powodzenia $\mathrm{w}$ różnych dziedzinach życia (por. Matczak, 2007a). Badacze są jednak zdecydowanie bardziej sceptyczni. Przykładowo, Mayer i in. (2004) spodziewają się, że inteligencja emocjonalna będzie wyjaśniała zaledwie kilka procent wariancji w tym zakresie. Na razie jednak nie dysponujemy odpowiednią ilością danych empirycznych na ten temat.

Nie można zaprzeczyć adaptacyjnym funkcjom emocji: informacyjnej, motywującej oraz komunikacyjnej; stąd już blisko do potwierdzenia adaptacyjnej roli inteligencji emocjonalnej bazującej na materiale emocjonalnym. Na przykład, takie zdolności wchodzące w skład inteligencji emocjonalnej, które są odpowiedzialne za percepcję emocji własnych i cudzych oraz ich prawidłową ekspresję, umożliwiają odbiór wielu istotnych dla działania informacji oraz warunkują prawidłowe kontakty społeczne. Inteligencja emocjonalna może ułatwiać jednostce funkcjonowanie w rolach społecznych, zwłaszcza w roli ucznia lub pracownika, zarówno jeśli chodzi o aspekt poznawczy, jak i społeczny.

Generalnie można się spodziewać, że osoby dobrze funkcjonujące w obszarze inteligencji emocjonalnej będą w sposób pełniejszy wykorzystywać 
własny potencjał samoaktualizacji i twórczości (np. Bar-On, 2001; por. Matczak, 2007a). Będą także lepiej funkcjonować w sytuacjach trudnych czy stresujących, mieć lepsze relacje z innymi, cieszyć się lepszym samopoczuciem.

Istnieje hipotetyczny model wpływu inteligencji emocjonalnej na funkcjonowanie jednostki zaproponowany przez Ciarrocchiego i współpracowników (Ciarrocchi, Chan, Caputi, Roberts, 2001). Według nich osoby z wysoką inteligencją emocjonalną lepiej radzą sobie w codziennych sytuacjach wywołujących emocje, jak również w sytuacjach silnie stresogennych, są lepiej przystosowane, co skutkuje u nich lepszym zdrowiem fizycznym, psychicznym, lepszą jakością relacji międzyludzkich oraz większymi sukcesami szkolnymi i zawodowymi.

Przytoczę pokrótce wybrane dane empiryczne na temat roli inteligencji emocjonalnej w życiu człowieka. Stwierdzono m.in., że młodzież o wysokim poziomie inteligencji emocjonalnej jest mniej agresywna, bardziej grzeczna, popularna, ma lepsze wyniki w nauce oraz podejmuje właściwsze decyzje w sprawie seksu (Goleman, 1997). Inne badania wykazały, że młodzi ludzie wykazujący problemy społeczne posiadają niskie zdolności w zakresie spostrzegania i interpretacji emocji innych ludzi (McCrown, Johnson, Austin, 1986, za: Van der Zee, Thijs, Schakel, 2002).

Charbonneau i Nicol (2002) uzyskały wyniki mówiące o tym, że młodzież w wieku 13-18 lat wyżej ocenia pod względem altruizmu i cnót obywatelskich rówieśników, którzy posiadają wysoką inteligencję emocjonalną.

Istnieją badania dowodzące, że dzieci lepiej odczytujące emocje innych osób osiągają wyższy status społeczny wśród rówieśników (Cole, Putnam, 1992; Erickson, Egeland, Pianta, 1989, za: Saarni, 1999), zaś dzieci przejawiające silne napięcie emocjonalne, przeżywające silne emocje negatywne oraz zmienne nastroje nie cieszą się popularnością wśród rówieśników (Stocker, Dunn, 1990, za: Eisenberg, Fabes, Losoya, 1999). Dodge i Feldman (1990, za: Goleman, 1997) wykazali, że uczniowie szkoły średniej mający niewielu przyjaciół popełniali o wiele więcej błędów w kojarzeniu nazw emocji z odpowiednią ekspresją twarzy.

Na podstawie dostępnych danych można stwierdzić, że inteligencja emocjonalna sprzyja efektywnym sposobom radzenia sobie ze stresem. W badaniach przeprowadzonych wśród młodzieży ze szkół średnich odkryto istnienie dodatnich związków między inteligencją emocjonalną 
a skoncentrowanym na zadaniu stylem radzenia sobie ze stresem oraz poszukiwaniem kontaktów towarzyskich oraz ujemnych związków między inteligencją emocjonalną a skoncentrowanym na emocjach stylem radzenia sobie (por. Knopp, 2019). Inteligencja emocjonalna może przyczyniać się do skuteczniejszego radzenia sobie ze stresem u młodzieży poprzez wybieranie strategii, które są adaptacyjne - ukierunkowane na aktywne poradzenie sobie z problemem (styl zadaniowy) lub na obniżenie napięcia emocjonalnego poprzez przebywanie z innymi ludźmi i uzyskiwanie od nich wsparcia (styl nastawiony na poszukiwanie kontaktów towarzyskich; Matczak, Knopp, 2013). Podobne wnioski dotyczące tego, że osoby o wyższej inteligencji emocjonalnej w radzeniu sobie ze stresem korzystają ze wsparcia społecznego potwierdziły się również w innych badaniach (Śmieja, 2018).

W badaniach Jaworowskiej i Matczak (2008) okazało się, że osoby wybierane przez kolegów jako bardziej pomocne, asertywne i popularne przejawiały wyższą inteligencję emocjonalną niż osoby w ogóle nie typowane do tych kategorii.

Lopes, Salovey i Straus (2003) uzyskali wyniki świadczące o wpływie inteligencji emocjonalnej na relacje interpersonalne: $\mathrm{z}$ ich badań wynika, że osoby z wysoką inteligencją emocjonalną mają mniej negatywnych relacji z bliskimi przyjaciółmi $(-0,45)$, ogólnie bardziej pozytywne relacje z innymi $(0,27)$ oraz większe zadowolenie ze wsparcia rodzicielskiego $(0,22)$.

Niektóre badania (np. Schutte, Malouff, Simunek, McKenley, Hollander, 2002; por. Matczak, 2007a) pokazały, że wysoki poziom inteligencji emocjonalnej koresponduje z mniejszym obniżeniem się nastroju pod wpływem indukcji negatywnego stanu emocjonalnego oraz z większym wzrostem nastroju pod wpływem indukcji stanu pozytywnego. Osoby z wysoką inteligencją emocjonalną częściej przywołują wspomnienia pozytywne, niezależnie od tego, czy dzieje się to w warunkach skutkujących emocjami pozytywnymi czy też negatywnymi.

Inteligencja emocjonalna dodatnio koreluje ze szczęściem małżeńskim oraz ilością i bliskością relacji społecznych, zaś ujemnie - z dewiacyjnymi zachowaniami społecznymi (np. Brackett, Mayer, 2003). Niektórzy badacze wykazują jednak sceptycyzm co do istotności związku pomiędzy inteligencją a jakością relacji społecznych, zwracając uwagę na to, że nie dysponujemy takimi dowodami empirycznymi, które by ten związek systematycznie potwierdzały (por. Śmieja, 2018). 
Badania Śmiei i współpracowników (Śmieja, 2018) pokazują, że pozytywne związki inteligencji emocjonalnej z funkcjonowaniem człowieka w różnych obszarach są zależne od wielu zmiennych osobowościowych, sytuacyjnych czy motywacyjnych. Na przykład, w ich badaniach dotyczących takiej kwestii jak popularność w grupie społecznej stwierdzono, że inteligencja emocjonalna pozwala z czasem zdobywać sobie przyjaciół. Innymi słowy, osoby bardziej inteligentne emocjonalnie „zyskują przy bliższym poznaniu", gdyż ich potencjał ujawnia się w całej pełni dopiero w sytuacjach wykraczających poza rutynę dnia codziennego: nieszablonowych, trudnych lub kryzysowych. Innym przykładem są wyniki badań tej samej autorki, w których ujawniło się, że osoby o wysokiej inteligencji emocjonalnej tym pozytywniej postrzegają swojego partnera, im bardziej mają poczucie, że są przez niego idealizowane, co oczywiście w konsekwencji, z dużym prawdopodobieństwem, będzie skutkować wzmocnieniem ich relacji. W innych badaniach okazało się, że negocjatorzy bardziej inteligentni emocjonalnie potrafili w sytuacji negocjacji bardziej konsekwentnie dążyć do celu, nawet kiedy druga strona otwarcie prezentowała swoje emocje (pozytywne i negatywne), podczas gdy negocjatorzy mniej inteligentni emocjonalnie byli w tej sytuacji bardziej skłonni do ustępstw (Śmieja, 2018).

Wykazano dodatnią korelację inteligencji emocjonalnej lub jej poszczególnych składowych z szeroko pojętym powodzeniem szkolnym i akademickim (Barchard, 2003; Bar-On, 1997; Bracket, Mayer, Warner, 2004; Gil-Olarte, Palomera, Brackett, 2006; Halberstad, Hall, 1980; Schutte i in., 1998). Osoby o wyższej inteligencji emocjonalnej częściej odnoszą sukcesy w życiu zawodowym, lepiej też funkcjonują w środowisku pracy (Goleman, Boyatzis, McKee, 2002; Packiyanathan, Nanthagopan, 2020), cechują się większym zadowoleniem z życia (Di i in., 2020; Di Fabio, Kenny, 2016) oraz lepiej radzą sobie ze stresem (Shagini, Fiori, Bausseron, 2019).

Badania prowadzone pod kierunkiem Matczak i Knopp (2013) pozwalają na wnioskowanie, że wysoka inteligencja emocjonalna przekłada się m.in. na wyższe kompetencje społeczne, lepsze funkcjonowanie w bliskich związkach, częstsze przejawianie bezpiecznego stylu przywiązania, konstruktywne radzenie sobie w sytuacjach konfliktowych, rzadsze poczucie samotności, większą wrażliwość społeczną, wyższe poczucie własnej wartości, większą odporność na stres i częstsze stosowanie zadaniowego stylu radzenia sobie z nim. 
Podsumowując, należy uznać, że inteligencja emocjonalna ma niewątpliwe znaczenie adaptacyjne, jednakże niektórzy badacze wysuwają tezę, że nadmiar niektórych zdolności wchodzących w skład inteligencji emocjonalnej może być „szkodliwy”. Dotyczy to zwłaszcza sytuacji, kiedy dana osoba przejawia wysoki poziom tylko jednej ze zdolności składowych inteligencji emocjonalnej, przy jednoczesnym niskim poziomie pozostałych. I tak, np. „wybujała” zdolność do autopercepcji emocjonalnej może zwiększać podatność na depresję, myśli samobójcze i poczucie beznadziei (Ciarrochi, Deane, Anderson, 2002). Zbyt silna koncentracja na własnych emocjach (Gohm, Corser, Dalsky, 2005), czy też większa podatność ludzi o wysokiej inteligencji emocjonalnej na zmiany nastroju wywoływane sytuacyjnie może być czasami czynnikiem niekonstruktywnym (Petrides, Furnham, 2003). Również w związkach interpersonalnych czasem lepiej nieco idealizować drugą osobę, niż bardzo trafnie rozpoznawać jej stany emocjonalne, ich przyczyny i skutki (Śmieja, Orzechowski, 2008). Należy dodać, że zagrożenie szkodliwością nadmiaru zdolności inteligencji emocjonalnej nie występuje wtedy, kiedy wszystkie zdolności wchodzące w jej skład są u jednej i tej samej osoby na wysokim poziomie (Matczak, 2007a). Istnieją też poglądy sceptyczne uznające, że dominująca rola inteligencji emocjonalnej w takich obszarach ludzkiego życia jak np. praca zawodowa jest trochę przereklamowana i nie do końca - przynajmniej na dany moment - empirycznie uzasadniona.

Nie należy przeceniać znaczenia inteligencji emocjonalnej, gdyż funkcjonowanie jednostki zależy również od jej innych właściwości indywidualnych, od sytuacji, w jakiej się znajduje oraz od tego, czy potrafi wykorzystywać swoją inteligencję emocjonalną (Matczak, 2007a). Chociaż sama inteligencja emocjonalna nie okazała się lepszym predyktorem osiągnięć w różnych dziedzinach życia niż tradycyjny IQ, to jednak uwzględnienie jej obok innych zdolności i cech może zwiększać trafność prognozowania sukcesów. Inteligencja emocjonalna, tak jak inteligencja ogólna, z pewnością pozwala na lepszą adaptację do środowiska, co ma znaczenie szczególnie w sytuacjach trudnych, wymagająch rozwiązywania problemów, kiedy to inteligencja emocjonalna może pełnić rolę kompensacyjną (Śmieja, 2018). 


\section{Rozdział 4.}

\section{Różnice międzypłciowe w zakresie inteligencji emocjonalnej}

Różnice psychologiczne między kobietami a mężczyznami zdają się istnieć od niepamiętnych czasów (por. Crabb, 1994; Horney, 2012; Kimura, 2006; Moir, Jessel, 1993; Pospiszyl, 1992; Wojciszke, 2002, 2006) i, pomimo ogromnych przemian społeczno-kulturowych, jakie przeszliśmy w ostatnich dziesięcioleciach, te różnice zdają się nie znikać. Psychologia kobiety i psychologia mężczyzny to próba zrozumienia i zgłębienia funkcjonowania dwóch odrębnych „mikrokosmosów” (Levassort, 1985), których zróżnicowanie przenika do powszechnej świadomości za sprawą licznych poradników i książek popularnonaukowych, których celem jest ułatwienie wzajemnego zrozumienia i „skomunikowania się" tych „mikroświatów” (np. Bartosz, 2011; Białopiotrowicz, 2005; Gray, 2011). W studiach nad rodzajem (gender studies) zwraca się często uwagę na konieczność rozdzielenia pojęć sex (płeć) i gender (rodzaj), argumentując to tym, że pierwsze odnosi się do cech wrodzonych (biologicznych), a drugie dotyczy cech nabytych i jest rozumiane jako określenie zespołu cech, postaw, ról społecznych i zachowań przypisanych poszczególnym płciom przez kulturę (Bem, 2000). Trwające od dłuższego czasu duże zainteresowanie tematem różnic międzypłciowych jest spowodowane częściowo ekspansją ruchów feministycznych na świecie. Także w Polsce pojawiły się prace związane z tym tematem (np. Budohoska, Grabowska, 1994; Pospiszyl, 1978, 1992; Promińska, 1987; Wojciszke, 2002).

Potoczna opinia na temat kobiet i mężczyzn każe wierzyć, że te pierwsze reprezentują "płeć emocjonalną" doświadczającą okresowych epizodów „huśtawki emocjonalnej”, w przeciwieństwie do mniej emocjonalnych (i mniej labilnych emocjonalnie) mężczyzn, co potwierdza silny stereotyp 
kobiet postrzeganych jako hipoemocjonalnych (Heesacker i in., 1999). Kobiety są uznawane za bardziej ekspresywne emocjonalnie, częściej i silniej przeżywające emocje, ale też wrażliwsze na emocje innych (Robinson, Johnson, 1997; Shaffer, 2000). Czy jest tak faktycznie? Czy mężczyźni mniej „czują", a więcej „myślą”, podczas gdy u kobiet jest odwrotnie? Takie stwierdzenie wydaje się być zbyt silnym uproszczeniem. Jest tak, tym bardziej że eksperci zajmujący się tematem emocji utrzymują, że pewne aspekty doświadczeń emocjonalnych są niezależne kulturowo i uniwersalne, zatem również niezależne od płci (Ekman, Levenson, Friesen, 1983).

Pytania dotyczące różnic międzypłciowych w obszarze inteligencji emocjonalnej zrodziły się na podstawie danych z piśmiennictwa psychologicznego potwierdzających, że występują różnice międzypłciowe w zakresie funkcjonowania emocjonalnego (np. Guastello, Guastello, 2003; Kring, Gordon, 1993; Moir, Jessel, 1993; Polce-Lynch, Myers, Kilmartin, Forssmann-Falck, Kliewer, 1998; Pospiszyl, 1992; Rosenthal, DePaulo, 1979). Istniejące dane $\mathrm{z}$ literatury przemawiają za istnieniem różnic międzypłciowych w obszarze inteligencji emocjonalnej (por. Austin, 2005; Ciarrochi, Chan, Bajgar, 2001; Ciarrochi i in., 2000; Day, Carroll, 2004; Jaworowska, Matczak, 2008; Matczak, Jaworowska, 2006; Matczak i in., 2005; Mayer i in., 1999; Ogińska-Bulik, 2005; Schutte i in., 1998).

\subsection{Przegląd danych $z$ literatury}

Wyniki testów i kwestionariuszy mierzących inteligencję emocjonalną nie zawsze ujawniają różnice międzypłciowe w ogólnym poziomie inteligencji emocjonalnej i często są niejednoznaczne, aczkolwiek rezultaty wielu z nich przemawiają na korzyść kobiet (np. Austin, 2005; Austin, Evans, Goldwater, Potter, 2005; Ciarrochi i in., 2000; Day, Carroll, 2004; Extremera, 2019; Jaworowska, Matczak, 2008; Kafetsios, 2004; Matczak, Jaworowska, 2006; Matczak i in., 2005; Mayer i in., 1999; Mayer, Geher, 1996; Ogińska-Bulik, 2005; Petrides, Furnham, 2000b; Schutte i in., 1998). Przykładowo, Charbonneau i Nicol (2002), przeprowadzając badania młodzieży w wieku 13-18 lat, stwierdzili, że dziewczęta uzyskały wyższe wyniki od chłopców w samoopisowym kwestionariuszu autorstwa Schutte i współpracowników (1998). Podobne rezultaty uzyskał w swoich badaniach zespół badawczy samej Schutte (1998). Z kolei sprzeczne z wyżej cytowanymi wyniki dotyczące 
nastolatków uzyskano w badaniach przeprowadzonych w Izraelu (Zeidner, Shani-Zinovich, Matthews, Roberts, 2005), gdzie chłopcy w wieku ok. 14-15 lat wypadli lepiej od dziewcząt pod względem zdolności emocjonalnych. Badania przeprowadzone na chińskich nastolatkach wykazały przewage dziewcząt w zakresie zdolności do rozumienia emocji innych osób, zaś przewagę chłopców - w zakresie regulacji emocji (Di, Deng, Zhao, Kong, 2020).

W badaniach polskich, w których zastosowano DINEMO (Matczak, Jaworowska, 2006) sprawdzano poziom inteligencji emocjonalnej u gimnazjalistów, uczniów szkół średnich oraz u osób dorosłych. Kobiety uzyskały w nich wyższe wyniki ogólne na wszystkich poziomach wieku, a także wyższe wyniki dotyczące inteligencji emocjonalnej interpersonalnej. W zakresie inteligencji emocjonalnej intrapersonalnej przewaga kobiet ujawniła się tylko w grupie osób dorosłych.

Przy testowym pomiarze inteligencji emocjonalnej (MEIS) Mayer, Salovey i Caruso (2000b) oraz Meyer i Geher (1996) okazało się, że kobiety uzyskiwały o około 0,5 odchylenia standardowego wyższe wyniki niż mężczyźni. Także Ciarrochi i in. (2000), którzy posłużyli się tym samym testem, stwierdzili wyższy ogólny wskaźnik inteligencji emocjonalnej u kobiet.

Istnieją również dowody na to, że o ile w badaniach dzieci i nastolatków odmienności między płciami w obszarze inteligencji emocjonalnej są wyraźne, o tyle już w przypadku studentów i osób dorosłych się one nie pojawiają (Bastian, Burns, Nettelbeck, 2005; Chan, 2004; Saklofske, Austin, Minski, 2003; Schutte i in., 2001) lub są bardzo niewielkie (Van Rooy, Alonso, Viswesvaran, 2005). Na przykład, polskie badania normalizacyjne dla kwestionariusza INTE wykazały, że średnie wyniki uczennic szkół średnich były istotnie wyższe niż uczniów, ale w grupach studentów i osób dorosłych nie odnotowano żadnych różnic (Jaworowska, Matczak, 2008). W badaniu przeprowadzonym przez Guastello i Guastello (2003), w którym sprawdzali oni zależności pomiędzy inteligencją emocjonalną studentów collegeów oraz ich rodziców, różnice międzypłciowe wystąpiły tylko w przypadku rodziców - matki uzyskały wyniki w kwestionariuszu Schutte i współpracowników (1998) o 0,44 odchylenia standardowego wyższe od ojców, natomiast podobna zależność nie wystąpiła w grupie studentów, co jest sprzeczne z cytowanymi wcześniej badaniami nastolatków.

Przeprowadzono także poszukiwania naukowe, w których nie wystąpiły różnice międzypłciowe co do ogólnego poziomu inteligencji emocjonalnej 
lub wystąpiły one znacznie mniej konsekwentnie. Jako przykład można podać polskie badania przy zastosowaniu PKIE (Jaworowska, Matczak, 2005) lub badania Bar-Ona (1997). W obu przypadkach nie stwierdzono istotnych statystycznie różnic pomiędzy ogólnym wskaźnikiem inteligencji emocjonalnej mężczyzn i kobiet. Zarazem jednak odnotowano takie różnice (nie zawsze świadczące o przewadze kobiet) w poszczególnych podskalach kwestionariuszy.

Innymi badaczami, którzy po przeanalizowaniu wyników uzyskanych za pomocą kwestionariusza Schutte i współpracowników (1998), nie stwierdzili różnic międzypłciowych w inteligencji emocjonalnej, byli Petrides i Furnham (2000b). Zauważyli natomiast różnice na korzyść kobiet w odniesieniu do zdolności społecznych. Okazało się też, że mężczyźni wyżej oceniali swoją inteligencję emocjonalną niż kobiety, pomimo braku obiektywnych przesłanek ku temu. To właśnie u mężczyzn stwierdza się większe predyspozycje do zaburzeń typu aleksytymia (Maruszewski, Ścigała, 1998), co jest tłumaczone przez autorów wzmacnianą kulturowo tendencją mężczyzn do koncentracji na zadaniach i osiąganiu sukcesów przy jednoczesnym pomijaniu sfery emocjonalnej, a także podłożem neurobiologicznym (silniejsza lateralizacja mózgu męskiego, a w konsekwencji pewna niewrażliwość na bodźce emocjonalne).

W literaturze przedmiotu znaleźć można nieliczne dane empiryczne, które ujawniają wyższe rezultaty mężczyzn w zakresie ogólnego wskaźnika inteligencji emocjonalnej (np. Ahmad, Bangash, Khan, 2009; Bindu, Thomas, 2006).

Inteligencja emocjonalna jest konstruktem złożonym, w skład którego wchodzi wiele różnych zdolności. Kiedy rozpatruje się globalny wskaźnik inteligencji emocjonalnej, wyniki wielu badań wskazują na przewagę kobiet nad mężczyznami w tym zakresie. Kiedy jednak bierze się pod uwagę poszczególne zdolności wchodzące w skład inteligencji emocjonalnej, przewaga ta przestaje być tak oczywista i jednoznaczna, a nawet w przypadku niektórych komponentów inteligencji emocjonalnej ujawnia się dominacja mężczyzn.

Płeć często różnicuje wyniki badań w obrębie zdolności do spostrzegania i rozpoznawania emocji. Kobiety cechują się większą wrażliwością na komunikaty niewerbalne, ułatwiającą im szybsze i trafniejsze rozpoznawanie emocji (Argyle, 1991; Brody, Hall, 2005; Fabes, Martin, 1991; Hall, 
Matsumoto, 2004), wykazując się szczególnie większą trafnością w rozpoznawaniu ekspresji mimicznej (Matczak i in., 2005). Różnice międzypłciowe w odczytywaniu emocji na podstawie wyrazu twarzy ujawniają się dość wcześnie. Wykazano, że ma to miejsce już od trzeciego roku życia i jest niezależne kulturowo (Elfenbein, Ambady, 2002). Potwierdziły to również polskie badania Piotrowskiej (1997), w których dzieci i młodzież badano testem polegającym na doborze opisów sytuacji związanych z emocjami do fotografii twarzy wyrażających różne emocje.

Także inne badania zgodnie potwierdziły większe zdolności rozpoznawania emocji u kobiet. Przykładowo, kobiety wypadały lepiej w tych skalach testu MEIS, które dotyczą spostrzegania emocji (Ciarrochi, Chan, Bajgar, 2001; Ciarrochi i in., 2000). W polskich badaniach za pomocą testu SIE-T stwierdzono istotne różnice statystyczne na korzyść kobiet u gimnazjalistów, uczniów szkół średnich i studentów. Nie wystąpiły one jednak w przypadku dorosłych (Matczak i in., 2005). Różnice międzypłciowe w grupie dorosłych $\mathrm{w}$ zakresie percepcji emocji wystąpiły w przypadku badania przeprowadzonego przy użyciu polskiej adaptacji kwestionariusza TEIQue Petridesa i Furnhama (Wytykowska, Petrides, 2007).

Istnieją jednak dane pokazujące, że przewaga kobiet w zakresie odczytywania kodu niewerbalnego dotyczy tylko emocji pozytywnych (Kirouac, Dore, 1985, za: Dolata, 2001), podczas gdy np. emocję gniewu lepiej rozpoznają mężczyźni (Elfenbein, Ambady, 2002).

Kolejnym komponentem inteligencji emocjonalnej, w zakresie którego występują różnice międzypłciowe jest zdolność wyrażania emocji. Kobiety charakteryzują się bogatszą i bardziej intensywną ekspresją emocjonalną (Argyle, 1988; Brody, Hall, 2005; Kring, Gordon, 1998; Wytykowska, Petrides, 2007). Cechuje je wysyłanie czytelniejszych dla innych komunikatów emocjonalnych (Aronson, Wilkert, Akert, 1997; Polce-Lynch i in., 1998; Rosenthal, DePaulo, 1979). Istotne różnice w werbalnej ekspresji emocji stwierdzono już u małych dzieci. W badaniach okazało się, że dwuletnie dziewczynki używają więcej słów związanych z wyrażaniem emocji niż ich rówieśnicy chłopcy (Cervantes, Callanan, 1998). Ta prawidłowość dotyczy także osób dorosłych - kobiety w porównaniu z mężczyznami posługują się bardziej zróżnicowanym słownictwem do opisu emocji własnych i cudzych (Szczygieł, 2007; Szczygieł, Kiełkiewicz, 2005; Szczygieł, Kolańczyk, 2000). 
Ciekawe jest, że jeśli chodzi o wyniki badań dotyczące różnic w samym przeżywaniu emocji przez kobiety i mężczyzn, nie są one już tak jednoznaczne jak badania ujawniające różnice w zakresie ekspresji emocji (por. Brody, 1985; Brody, Hall, 2005). Istnieją dane empiryczne, w których nie stwierdzono różnic w częstotliwości przeżywania emocji przez kobiety i mężczyzn (Simon, Nath, 2004). Natomiast stwierdzono, że mężczyźni częściej przeżywają emocje pozytywne (np. przyjemność i ekscytacja), zaś kobiety - emocje negatywne (np. smutek, niepokój). Kobiety deklarowały przeżywanie złości intensywniej i dłużej niż mężczyźni, choć nie stwierdzono różnic w samej częstotliwości przeżywania złości. Okazało się także, że kobiety wykazywały tendencję do reagowania płaczem na uczucie złości, co być może wynika $\mathrm{z}$ faktu, że w przypadku kobiet mniej akceptowalną formą reakcji na złość jest fizyczna konfrontacja (mężczyźni są bardziej skłonni do wyrażania złości poprzez agresję fizyczną), a ponadto deklarowały bardziej intensywne jej przeżywanie (Averill, 1982, za: Brannon, 2002).

Fujita, Diener i Sandvik (1991) stwierdzili w przeprowadzonych przez siebie badaniach, że kobiety deklarują większą niż mężczyźni intensywność przeżywania emocji zarówno pozytywnych, jak i negatywnych. Silniejsze przeżywanie emocji deklarowały zwłaszcza te kobiety, u których stwierdzono silną identyfikację ze stereotypową rolą płciową (Grossman, Wood, 1993), więc mógł tu zadziałać „autoprezentacyjny” czynnik kulturowy. W przypadku jednak kiedy badano nie tylko deklaratywną, lecz faktyczną intensywność stanów emocjonalnych (badani prowadzili dzienniki emocji), nie stwierdzono statystycznie istotnych różnic pomiędzy kobietami i mężczyznami (np. Feldman-Barrett, 1997).

Dane empiryczne na temat autopercepcji kobiet w zakresie ekspresji emocjonalnej świadczą o tym, że kobiety odbierają siebie jako bardziej otwarte w ujawnianiu emocji (Pennebaker, Rime, Blankenship, 1996). Różnice międzypłciowe w sposobie wyrażania emocji tłumaczy się tym, że ekspresja emocji może w większym stopniu podlegać procesowi socjalizacji niż samo ich przeżywanie (Fischer, 2000; Kring, Gordon, 1998). Zatem, pomimo że wewnętrznie mężczyźni mogą być tak samo emocjonalni jak kobiety, rzadziej ujawniają swoje przeżycia emocjonalne.

Kolejnym komponentem inteligencji emocjonalnej, w zakresie którego ujawniają się różnice między kobietami a mężczyznami, jest zdolność do empatii. Kobiety są zdecydowanie bardziej empatyczne od mężczyzn 
(Eisenberg, Valiente, Champion, 2008; Mehrabian, Young, Sato, 1988; Pinker, 2009; Trobst, Collins, Embree, 1994). Polskie badania za pomocą PKIE potwierdziły wyraźną różnicę wyników w skali empatii na korzyść kobiet. Wystąpiła ona zarówno w grupie uczniów, jak i dorosłych (Jaworowska, Matczak, 2005). Podobne wyniki (w grupie osób dorosłych) uzyskano $\mathrm{w}$ badaniach za pomocą polskiej adaptacji kwestionariusza TEIQue (Wytykowska, Petrides, 2007).

Także w badaniach normalizacyjnych dla Testu Rozumienia Emocji (TRE; Matczak, Piekarska, 2011) kobiety uzyskały przewagę nad mężczyznami w całej grupie normalizacyjnej, a także w poszczególnych grupach wiekowych, przy czym jednak różnice w grupie osób w wieku powyżej 25 lat były tylko na poziomie tendencji. Zdolność do rozumienia emocji u kobiet odnosi się na ogół do emocji innych osób, a także do rozumienia sytuacji związanych z emocjami (np. Ciarrochi i in., 2000). Natomiast w przypadku zdolności do rozumienia i uświadamiania sobie własnych emocji nie jest to już tak oczywiste. Przykładowo, dla jednej z grup wiekowych (gimnazjaliści) w badaniach za pomocą PKIE stwierdzono przewagę w tym zakresie u mężczyzn (Jaworowska, Matczak, 2005).

Różnice międzypłciowe, podobne jak w zakresie rozumienia emocji, występują w obszarze zdolności do regulacji i kontroli emocjonalnej. Z badań wynika, że kobiety lepiej kontrolują i regulują emocje cudze (np. Ciarrochi i in., 2001), zaś mężczyźni - własne. We wspomnianych wcześniej badaniach za pomocą adaptacji skali TEIQue (Wytykowska, Petrides, 2007) oraz przy zastosowaniu PKIE (Jaworowska, Matczak, 2005) mężczyźni uzyskali lepsze niż kobiety rezultaty w skalach: samokontroli emocjonalnej i regulacji emocjonalnej.

Dane empiryczne pokazują na odmienność strategii stosowanych przez obie płcie w radzeniu sobie z własnymi emocjami. Kobiety częściej próbują poradzić sobie z emocjami negatywnymi poprzez rozmowę z innymi czy modlitwę, mężczyźni zaś sięgają po alkohol lub tabletki uspokajające (Simon, Nath, 2004). Z takim uczuciem jak np. złość kobiety radzą sobie w sposób werbalny, zaś mężczyźni - behawioralny (Frost, Averill, 1982; Kring, 2000). W sytuacjach stresujących, rodzących negatywne emocje kobiety są bardziej otwarte w wyrażaniu emocji i częściej poszukują wsparcia społecznego (Thoits, 1989). Mężczyźni raczej unikają koncentrowania się 
na uczuciach negatywnych, kobiety są bardziej skłonne do ich analizowania (Niedenthal, Krauth-Gruber, Ric, 2006).

Ciekawe wnioski uzyskano w polskich badaniach, w których zaobserwowano różnice międzypłciowe w reagowaniu na trudne sytuacje interpersonalne. Kobiety o wysokiej inteligencji emocjonalnej w sytuacji konfliktu z partnerem stosowały konstruktywne strategie rozwiązywania konfliktów, o ile były przekonane o sile uczuć bliskiej osoby. Jeśli natomiast nie wierzyły w uczucia partnera, to zamiast na ratowaniu związku, koncentrowały się na realizacji własnych, indywidualnych celów. Mężczyźni o wyższej inteligencji emocjonalnej, doświadczający trudności w bliskiej relacji, radzili sobie $\mathrm{z}$ emocjami poprzez poznawcze przeformułowanie problemu. Z kolei mężczyźni o niższej inteligencji emocjonalnej częściej tłumili emocje. Zatem poziom inteligencji emocjonalnej okazał się w większym stopniu determinować wybór strategii regulowania emocji u mężczyzn aniżeli u kobiet (Śmieja, 2018).

Badania mózgów kobiet i mężczyzn za pomocą rezonansu magnetycznego (fRMI) wykazały, że w zakresie zarządzania emocjami regulacja afektu przychodzi z mniejszym wysiłkiem mężczyznom niż kobietom, zaś kobiety częściej od mężczyzn wykorzystują uczucia pozytywne w celu obniżenia emocji negatywnych (McRae, Ochsner, Mauss, Gabrieli, Gross, 2008).

Tak jak w przypadku samooceny w zakresie poziomu własnej inteligencji ogólnej, tak również w zakresie oszacowania własnych zdolności emocjonalnych kobiety mają skłonność do niedoceniania ich, zaś mężczyźni do przeceniania (Petrides, Furnham, 2000b; Sánchez-Núñez, Fernández-Berrocal, Montañés, Latorre, 2008), co każe przypuszczać, że inteligencja emocjonalna rozumiana jako poczucie własnej skuteczności w obszarze emocji (Saarni, 1999) jest wyższa u mężczyn.

Kobiety często wykazują w badaniach wyższe zdolności interpersonalne oraz lepszą percepcję i ocenę emocji, zaś mężczyźni lepiej wypadają pod względem zdolności do wykorzystywania emocji w działaniu, w regulacji emocjonalnej i zarządzaniu emocjami (np. Besharat, 2007; Saklofske i in., 2003).

W badaniach Bar-Ona (1997) za pomocą stworzonego przez niego kwestionariusza EQ-i różnice wystąpiły jedynie w poziomie poszczególnych składowych inteligencji emocjonalnej. Kobiety lepiej „wypadły” w kwestiach kompetencji interpersonalnych (empatia, zdolność do tworzenia 
i utrzymywania więzi interpersonalnych, odpowiedzialność społeczna) oraz miały wyższą emocjonalną samoświadomość. Mężczyźni z kolei wykazali się większą asertywnością, samoakceptacją, niezależnością, umiejętnościami adaptacyjnymi, tolerancją na stres i optymizmem. Wyniki tych badań potwierdzałyby przypuszczenie o mocniejszych i słabszych stronach inteligencji emocjonalnej u mężczyzn, jak i u kobiet (Goleman, 1999). Kobiety są przeciętnie na ogół bardziej uzdolnione, jeśli chodzi o odczytywanie sygnałów emocjonalnych, ekspresję własnych emocji oraz rozumienie i regulowanie emocji innych ludzi. Mężczyźni z kolei wykazują większe zdolności w zakresie zarządzania własnymi emocjami, ich rozumienia i kontroli. Stereotypem zatem jest kojarzenie kobiet $\mathrm{z}$ większą emocjonalnością, a mężczyzn z większą racjonalnością. Różnice między nimi dotyczą raczej sposobów i okoliczności okazywania przeżywanych uczuć. Dalszą część pracy poświęcam prezentacji wyników badań własnych na ten temat.

\subsection{Prezentacja wyników badań własnych}

Postawiono pytania badawcze dotyczące różnic międzypłciowych w obrębie inteligencji emocjonalnej - tego, czy dotyczą one ogólnego poziomu inteligencji emocjonalnej, czy też przejawiają się w zróżnicowaniu profilowym inteligencji emocjonalnej kobiet i mężczyzn. Na podstawie dotychczasowych danych empirycznych można mniemać, że różnice międzypłciowe w poruszanym temacie dotyczą raczej profilu zdolności, a nie ich ogólnego poziomu. Stąd sformułowano następujące hipotezy:

- $\quad$ kobiety wykazują wyższy poziom inteligencji emocjonalnej doświadczeniowej, zwłaszcza w zakresie jej czynnika poznawczego związanego z rozumieniem emocji innych ludzi (empatia);

- mężczyźni wykazują wyższy poziom inteligencji emocjonalnej strategicznej, zarówno w zakresie czynnika poznawczego (rozumienie), jak i czynnika działaniowego (kontrola).

Badania były wykonywane przez autorkę pracy. Prowadzone były grupowo w dużych miastach takich jak Warszawa, Bydgoszcz, Poznań i Wrocław. Osobami badanymi byli dorośli w wieku $18-33$ lata $(M=22,17 ; S D=3,10)$ z wykształceniem minimum średnim. Byli to głównie studenci studiów 
dziennych i zaocznych różnych kierunków (m.in. takich jak medycyna, budownictwo, teologia, dziennikarstwo, filozofia, prawo). Osoby badane wypełniały najpierw kwestionariusz PKIE - Popularny kwestionariusz inteligencji emocjonalnej, a potem kwestionariusz FCZ-KT - Formalna charakterystyka zachowania - Kwestionariusz temperamentu. Każda z osób badanych dysponowała dokładną instrukcją postępowania, jak również była poinformowana o celu badań. Badania były dobrowolne i anonimowe. Zbadanych zostało około 1000 osób. Po odrzuceniu niekompletnie wypełnionych arkuszy do grupy włączono 716 osób, w tym 415 kobiet i 301 mężczyzn.

Do pomiaru inteligencji emocjonalnej zastosowano PKIE autorstwa Matczak, Jaworowskiej, Ciechanowicz, Stańczak i Zalewskiej (por. Jaworowska, Matczak, 2005). Narzędzie to oparte jest na koncepcji inteligencji emocjonalnej stworzonej przez amerykańskich psychologów Saloveya i Mayera. W myśl tej koncepcji inteligencja emocjonalna rozumiana jest jako zbiór zdolności o charakterze poznawczym, dzięki którym człowiek korzysta z emocji przy rozwiązywaniu problemów nie tylko natury emocjonalnej.

Kwestionariusz ten składa się z 94 pozycji o charakterze stwierdzeń występujących w pierwszej osobie liczby pojedynczej. Respondent dokonuje oceny stopnia zgodności każdego stwierdzenia $\mathrm{z}$ własną osobą na pięciopunktowej skali: zdecydowanie nie zgadzam się, raczej nie zgadzam się, trudno powiedzieć, raczej zgadzam się, zdecydowanie zgadzam się. Część pozycji kwestionariusza ma odwrócony klucz. Popularny kwestionariusz inteligencji emocjonalnej pozwala na obliczenie wyniku ogólnego oraz wyników w czterech skalach: AKC (akceptowanie, wyrażanie i wykorzystywanie własnych emocji w działaniu), EMP (empatia, czyli rozumienie i rozpoznawanie emocji innych ludzi), KON (kontrola, także poznawcza, nad własnymi emocjami) oraz ROZ (rozumienie i uświadamianie sobie własnych emocji), co pozwala na analizę profilową inteligencji emocjonalnej badanych. Poszczególne skale PKIE pozwalają na pomiar różnych typów inteligencji emocjonalnej: poznawczej (skale empatii i rozumienia) i działaniowej (skale akceptowania i kontroli), strategicznej (skale rozumienia i kontroli) i doświadczeniowej (skale empatii i akceptowania) oraz intrapersonalnej (skale rozumienia, akceptowania i kontroli) i interpersonalnej (skala empatii).

Rzetelność wyniku ogólnego PKIE jest bardzo wysoka - we wszystkich grupach osiąga wartość co najmniej 0,90, w niektórych zaś go przekracza. 
Rzetelność poszczególnych skal jest niższa - w grupie uczniów oscyluje wokół wartości 0,70 , zaś w grupie dorosłych - wokół wartości 0,80. Pozycje poszczególnych skal PKIE charakteryzują się trafnością treściową o ładunkach oscylujących wokół wartości 0,50.

Wyniki w zakresie ogólnej inteligencji emocjonalnej, jak i w zakresie poszczególnych zdolności emocjonalnych dla grupy kobiet przedstawia tabela 3 , zaś dla grupy mężczyzn - tabela 4 .

Tabela 3

Wyniki pomiaru inteligencji emocjonalnej $w$ grupie kobiet $(\mathrm{N}=415)$

\begin{tabular}{ccccc}
\hline Zmienna & Min & Max & $\boldsymbol{M}$ & SD \\
\hline AKC & 19 & 75 & 54,32 & 8,80 \\
EMP & 21 & 90 & 70,89 & 8,56 \\
KON & 11 & 55 & 31,59 & 7,19 \\
ROZ & 13 & 49 & 33,21 & 6,59 \\
WO & 163 & 450 & 338,72 & 36,04 \\
\hline
\end{tabular}

Adnotacja. Skale PKIE: AKC - akceptowanie; EMP - empatia; KON - kontrola; ROZ - rozumienie; WO - wynik ogólny w PKIE.

Tabela 4

Wyniki pomiaru inteligencji emocjonalnej w grupie mężczyzn $(\mathrm{N}=301)$

\begin{tabular}{ccccc}
\hline Zmienna & Min & Max & $\boldsymbol{M}$ & SD \\
\hline AKC & 26 & 74 & 52,95 & 0,89 \\
EMP & 42 & 88 & 68,33 & 8,20 \\
KON & 12 & 53 & 34,96 & 7,09 \\
ROZ & 13 & 50 & 34,38 & 6,84 \\
WO & 205 & 435 & 338,03 & 37,51 \\
\hline
\end{tabular}

Adnotacja. Skale PKIE: AKC - akceptowanie; EMP - empatia; KON - kontrola; ROZ - rozumienie; WO - wynik ogólny w PKIE. 
Średnia wyników uzyskanych z uwzględnieniem płci w przypadku wyniku ogólnego inteligencji emocjonalnej okazała się zbliżona do średniej z badań normalizacyjnych. Również średnie uzyskane dla wyników w poszczególnych skalach PKIE, zarówno dla kobiet, jak i mężczyzn, były podobne do wyników próby normalizacyjnej (por. Jaworowska, Matczak, 2005).

Dalsze analizy dotyczyły porównania wyników obu płci (tabela 5). Zastosowano w tym celu test $U$ Manna-Whitneya (zrezygnowano z testu $t$-Studenta, gdyż badane grupy nie spełniały kryterium równoliczności).

Tabela 5

Porównanie kobiet $(\mathrm{N}=415)$ i mężczyzn $(\mathrm{N}=301)$ w zakresie inteligencji emocjonalnej

\begin{tabular}{ccccc}
\hline Kobiety & Mężczyźni & & \\
Zmienna & śr. ranga & śr. ranga & $\boldsymbol{U}$ & Efekt $\boldsymbol{r}$ \\
\hline AKC & 373,23 & 338,19 & $56345,5^{*}$ & 0,08 \\
EMP & 386,83 & 319,44 & $50699,0^{* * *}$ & 0,16 \\
KON & 319,15 & 412,75 & $46127,5^{* * *}$ & 0,22 \\
ROZ & 344,92 & 377,22 & $56821,5^{*}$ & 0,08 \\
WO & 363,48 & 351,64 & 60391,5 & 0,03 \\
\hline
\end{tabular}

Adnotacja. Skale PKIE: AKC - akceptowanie; EMP - empatia; KON - kontrola; ROZ - rozumienie; WO - wynik ogólny w PKIE.

${ }^{\star} p<0,05 ;{ }^{* *} p<0,001$.

Z uzyskanych rezultatów wynika, że w odniesieniu do ogólnego poziomu inteligencji emocjonalnej kobiet i mężczyzn różnica między nimi jest niewielka i nieistotna statystycznie. Ujawniły się natomiast istotne różnice międzypłciowe w przypadku poszczególnych skal wchodzących w zakres PKIE. Kobiety uzyskały nieco wyższe od mężczyzn wyniki w obszarze akceptowania emocji i empatii. Mężczyźni górowali nad kobietami w zakresie kontroli emocjonalnej i rozumienia emocji. Widać, że analiza profilowa inteligencji emocjonalnej kobiet i mężczyzn wykazuje różnice, jednak trzeba dodać, że nie są one duże (efekt płci dla wyników wszystkich podskal PKIE był słaby). 
Jak była już o tym wcześniej mowa, dwie pierwsze wymienione skale, czyli akceptacja emocji i empatia, wchodzą w skład inteligencji emocjonalnej doświadczeniowej, zaś dwie kolejne: kontrola i rozumienie emocji - w skład inteligencji emocjonalnej strategicznej. Uzyskane różnice w inteligencji emocjonalnej kobiet i mężczyzn są zgodne $\mathrm{z}$ dotychczasowymi danymi z literatury na ten temat. Kobiety wydają się cechować wyższą inteligencją emocjonalną doświadczeniową niż mężczyźni, zaś mężczyźni - wyższą od kobiet inteligencją emocjonalną strategiczną (por. Jaworowska, Matczak, 2005). To zróżnicowanie profilowe inteligencji emocjonalnej potwierdza przypuszczenie, że jako kobiety i mężczyźni w jej obrębie posiadamy mocne i słabe strony.

\subsubsection{Profile inteligencji emocjonalnej kobiet i mężczyzn w od- niesieniu do inteligencji emocjonalnej doświadczeniowej vs. stra- tegicznej. W grupie normalizacyjnej autorki PKIE (Jaworowska, Matczak,} 2005) przeprowadziły analizę skupień (metodą wiązania $k$-średnich) w celu wyodrębnienia grup osób o podobnych profilach inteligencji emocjonalnej. Analiza ta zaowocowała czterema typowymi profilami inteligencji emocjonalnej: WIE - wysoka inteligencja emocjonalna, czyli wysokie wyniki we wszystkich czterech skalach; PIE - przeciętna inteligencja emocjonalna, czyli przeciętne wyniki we wszystkich czterech skalach; STR - wysokie wyniki w skalach odpowiadających strategicznej inteligencji emocjonalnej, czyli kontroli i rozumienia, przy dużo niższych wynikach w skalach akceptowania i empatii; DOŚW - wysokie wyniki w obszarze doświadczeniowej inteligencji emocjonalnej, a więc w skali akceptowania i empatii, przy dużo niższych wynikach w skalach kontroli i rozumienia.

Nawiązując do analiz opisanych w podręczniku, w badaniach własnych podzielono badanych na cztery skupienia (również metodą $k$-średnich). Zarówno w grupie kobiet jak i w grupie mężczyzn zasadne było nazwanie uzyskanych skupień tak, jak w podręczniku: WIE, PIE, DOŚW i STR. Zdecydowano zastosować arbitralne kryteria podziału badanych na profile. Kryterium było pół odchylenia standardowego od średniej wewnątrz płci, z tym że uśredniano standaryzowane wyniki dwu skal wchodzących w skład danego typu inteligencji emocjonalnej. I tak, wskaźnikiem doświadczeniowej inteligencji emocjonalnej była średnia $\mathrm{z}$ wystandaryzowanych wyników skal akceptowania i empatii, zaś wskaźnikiem strategicznej inteligencji 
emocjonalnej - skal kontroli i rozumienia. Liczebność osób zaklasyfikowanych do poszczególnych profili inteligencji emocjonalnej zestawiona jest w tabeli 6 .

Tabela 6

Liczebność kobiet i mężczyzn zaklasyfikowanych do poszczególnych profili inteligencji emocjonalnej

\begin{tabular}{ccccc}
\hline & \multicolumn{2}{l}{ Kobiety $(\boldsymbol{N}=\mathbf{4 1 5})$} & \multicolumn{2}{c}{ Mężczyźni $(\mathbf{N}=\mathbf{3 0 1})$} \\
\hline Profil IE & $\boldsymbol{N}$ & $\%$ & $\boldsymbol{N}$ & $\%$ \\
\hline WIE & 52 & $12,5 \%$ & 41 & $13,6 \%$ \\
PIE & 90 & $21,7 \%$ & 50 & $16,6 \%$ \\
NIE & 46 & $11,1 \%$ & 30 & $10,0 \%$ \\
STR & 106 & $25,5 \%$ & 91 & $30,2 \%$ \\
DOŚW & 121 & $29,2 \%$ & 89 & $29,6 \%$ \\
\hline
\end{tabular}

Adnotacja. NIE - niska inteligencja emocjonalna; PIE - przeciętna inteligencja emocjonalna; WIE - wysoka inteligencja emocjonalna; STR - wysoka (lub przeciętna) inteligencja emocjonalna strategiczna; DOŚW - wysoka (lub przeciętna) inteligencja emocjonalna doświadczeniowa.

$\mathrm{Na}$ rysunku 2 przedstawiono uśrednione profile inteligencji emocjonalnej u kobiet, zaś na rysunku 3 analogicznie przedstawiono uśrednione profile inteligencji emocjonalnej u mężczyzn. 


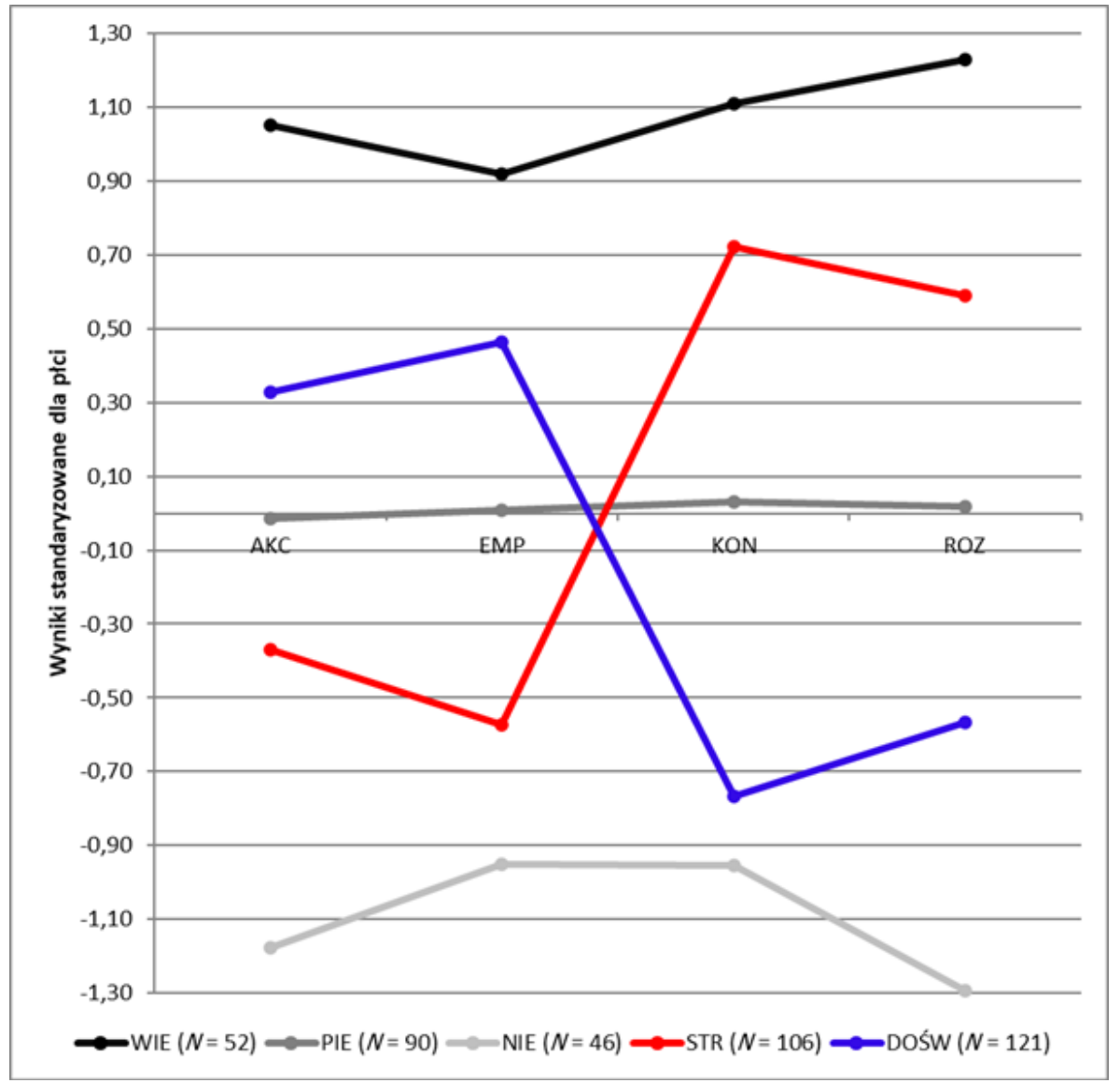

Rysunek 2. Uśrednione profile inteligencji emocjonalnej u kobiet.

Adnotacja. NIE - niska inteligencja emocjonalna; PIE - przeciętna inteligencja emocjonalna; WIE - wysoka inteligencja emocjonalna; STR - wysoka (lub przeciętna) inteligencja emocjonalna strategiczna; DOŚW - wysoka (lub przeciętna) inteligencja emocjonalna doświadczeniowa; Skale PKIE: AKC - akceptowanie; EMP - empatia; $\mathrm{KON}$ - kontrola; $\mathrm{ROZ}$ - rozumienie. 


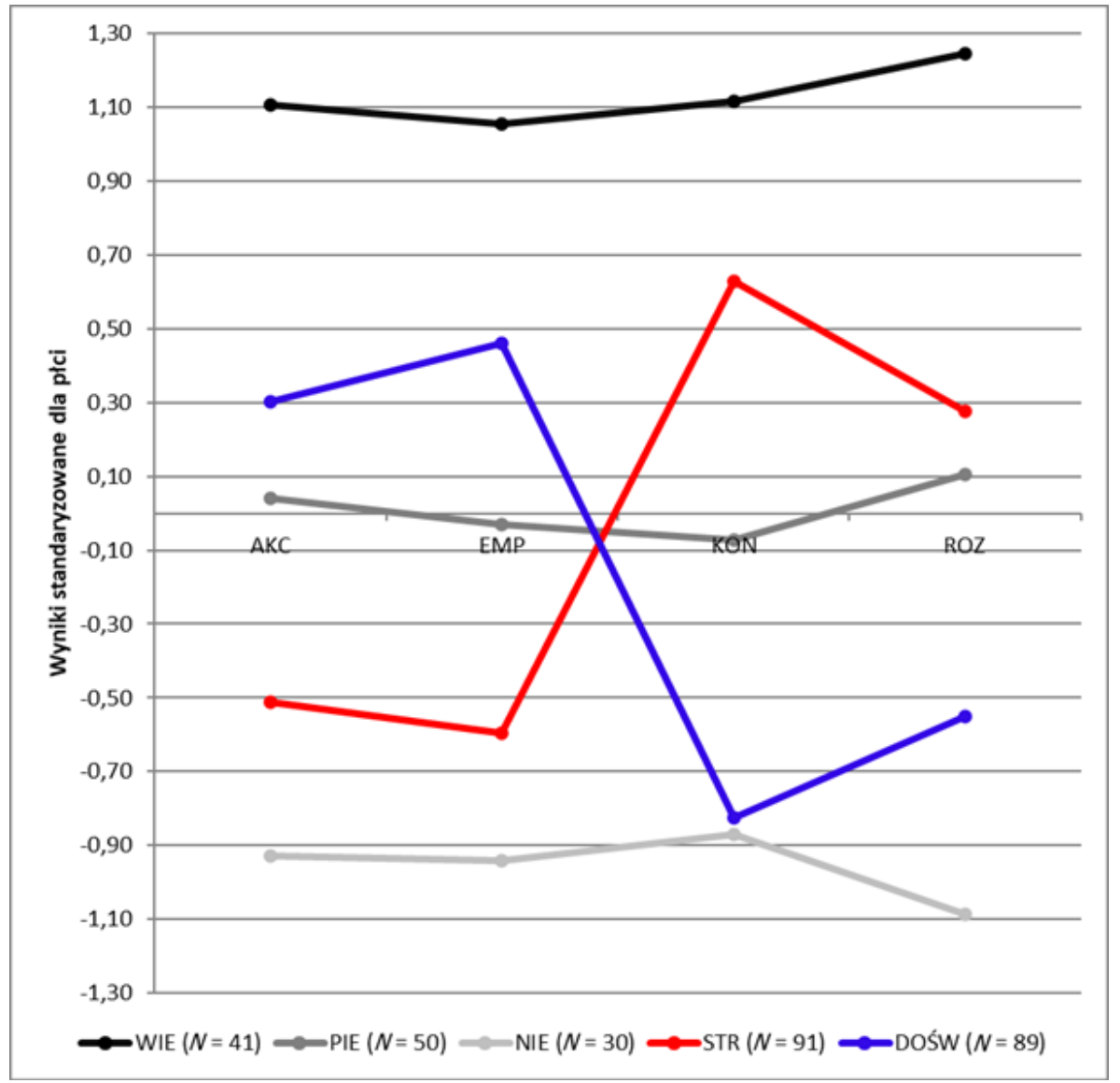

Rysunek 3. Uśrednione profile inteligencji emocjonalnej u mężczyzn.

Adnotacja. NIE - niska inteligencja emocjonalna; PIE - przeciętna inteligencja emocjonalna; WIE - wysoka inteligencja emocjonalna; STR - wysoka (lub przeciętna) inteligencja emocjonalna strategiczna; DOŚW - wysoka (lub przeciętna) inteligencja emocjonalna doświadczeniowa; Skale PKIE: AKC - akceptowanie; EMP - empatia; $\mathrm{KON}$ - kontrola; $\mathrm{ROZ}$ - rozumienie.

Na rysunkach powyżej widać, że zarówno u kobiet, jak i u mężczyzn profile wysokich, przeciętnych i niskich wyników w zakresie inteligencji emocjonalnej są spłaszczone i znajdują się na różnych wysokościach. Profil inteligencji emocjonalnej osób z wysoką inteligencją emocjonalną strategiczną różni się od profilu osób z wysoką inteligencją doświadczeniową 
nie tylko kierunkiem różnicy, ale i poziomem poszczególnych zmiennych. Średnia wszystkich czterech zdolności emocjonalnych jest wyższa u osób z przewagą inteligencji strategicznej niż u osób z przewagą inteligencji doświadczeniowej.

Profil DOŚW, czyli osoby o przewadze inteligencji emocjonalnej doświadczeniowej nad strategiczną, miał inną charakterystykę u kobiet i u mężczyzn. U kobiet typowy profil z tego skupienia cechował się przeciętnym (dla płci) poziomem empatii $(z=-0,09)$, obniżonym (a nie wysokim, czy nawet przeciętnym!) poziomem akceptacji $(z=-0,69)$, niskim poziomem kontroli $(z=-1,14)$ oraz rozumienia $(z=-1,18)$. Można by skupieniu z takimi średnimi nadać nazwę NIE, czyli niska inteligencja emocjonalna. W grupie mężczyzn profil DOŚW bardziej odpowiadał modelowi stworzonymi przez autorki PKIE. Średnie wyniki poziomu kontroli $(z=-1,04)$ i rozumienia $(z=-0,93)$ były niskie na tle płci, ale zarówno wyniki poziomu akceptacji $(z=-0,20)$, jak i empatii $(z=0,40)$ były przeciętne.

Profil STR, czyli osoby o przewadze inteligencji emocjonalnej strategicznej, w grupie kobiet charakteryzował się wyraźną przewagą obu skal inteligencji emocjonalnej strategicznej (kontrola: $z=0,29$; rozumienie: $z=$ $-0,15)$ nad skalami inteligencji emocjonalnej doświadczeniowej (akceptowanie: $z=-1,19$; empatia: $z=-1,44)$. Skale inteligencji strategicznej mają średnio przeciętny poziom, a doświadczeniowej - niski. W grupie mężczyzn skupienie, nazwane przez analogię STR, jest opisane przez niską średnią w obrębie empatii $(z=-1,11)$ i akceptacji $(z=-0,83)$, prawie niezauważalnie wyższą średnią w rozumieniu $(z=-0,74)$ i przeciętny, choć poniżej średniej, wynik kontroli emocjonalnej $(z=-0,32)$. To skupienie mogłoby być również nazwane NIE (niska inteligencja emocjonalna), ze względu na obniżone wyniki poszczególnych zdolności emocjonalnych.

W dalszej części pracy przedstawiam analizy inteligencji emocjonalnej kobiet i mężczyzn w odniesieniu do jej podziału na poznawczą i działaniową.

\subsubsection{Profile inteligencji emocjonalnej kobiet i mężczyzn w od- niesieniu do inteligencji emocjonalnej poznawczej i działaniowej. Wśród kobiet i mężczyzn wyodrębniono osoby o przewadze komponentu działaniowego inteligencji emocjonalnej nad poznawczym oraz osoby}


o przewadze komponentu poznawczego inteligencji emocjonalnej nad działaniowym.

Aby wyodrębnić takie osoby, posłużono się zmienną, którą nazwano "przewagą komponentu poznawczego nad działaniowym” (tzw. przewaga POZN). Zmienna ta określa przewagę w obszarze takich zdolności emocjonalnych jak empatia i rozumienie emocji (a więc dotyczących komponentu poznawczego inteligencji emocjonalnej) nad zdolnościami akceptowania emocji i kontroli emocjonalnej (dotyczących z kolei komponentu działaniowego inteligencji emocjonalnej).

W celu wyodrębnienia tej zmiennej wystandaryzowano zmienne PKIE i uśredniono wartości wystandaryzowane dla skal wchodzących w jeden z komponentów (poznawczy i działaniowy). Następnie od średniej ze standardowych wartości skal reprezentujących poznawczą inteligencję emocjonalną odjęto średnią ze standardowych wartości skal reprezentujących działaniową inteligencję emocjonalną. Przyjęto, że wartość ujemna wskazuje na przewagę komponentu działaniowego nad poznawczym, wartość dodatnia - poznawczego nad działaniowym. Należy dodać, że przewaga dotyczyła miejsca w grupie odniesienia (czyli płci), a nie uzyskanych punktów za odpowiedzi w poszczególnych skalach. Dla większości badanych pytania wchodzące w skład skali empatii były „najłatwiejsze” (najwięcej uzyskanych wysoko punktowanych odpowiedzi wśród osób badanych), zaś wchodzące w skład skali kontroli - „najtrudniejsze” (najmniej odpowiedzi wysoko punktowanych wśród osób badanych).

Zmienna „przewaga komponentu poznawczego” posłużyła do wyodrębnienia osób o przewadze komponentu poznawczego lub działaniowego inteligencji emocjonalnej. Przyjęto, że wartość tej zmiennej poniżej-0,5 oznacza przewagę komponentu działaniowego nad poznawczym u danej osoby, a wartość powyżej 0,5 - przewagę komponentu poznawczego nad działaniowym.

Układ profilów inteligencji emocjonalnej kobiet i mężczyzn o przewadze poznawczego lub działaniowego składnika inteligencji emocjonalenj ilustrują rysunki 4 i 5. 


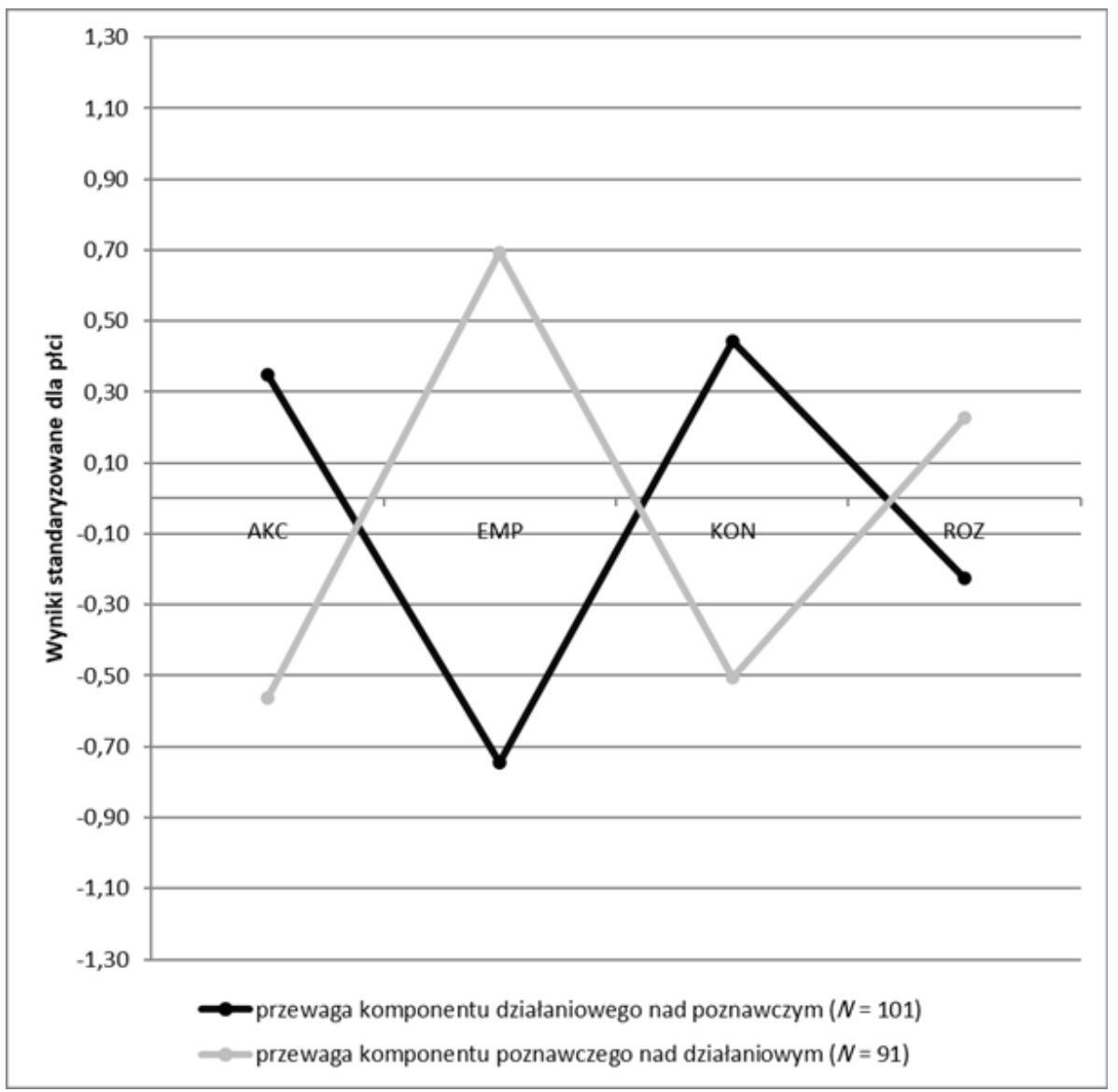

Rysunek 4. Uśrednione profile poznawczej i działaniowej inteligencji emocjonalnej u kobiet.

Adnotacja. Skale PKIE: AKC - akceptowanie; EMP - empatia; KON - kontrola; ROZ - rozumienie. 


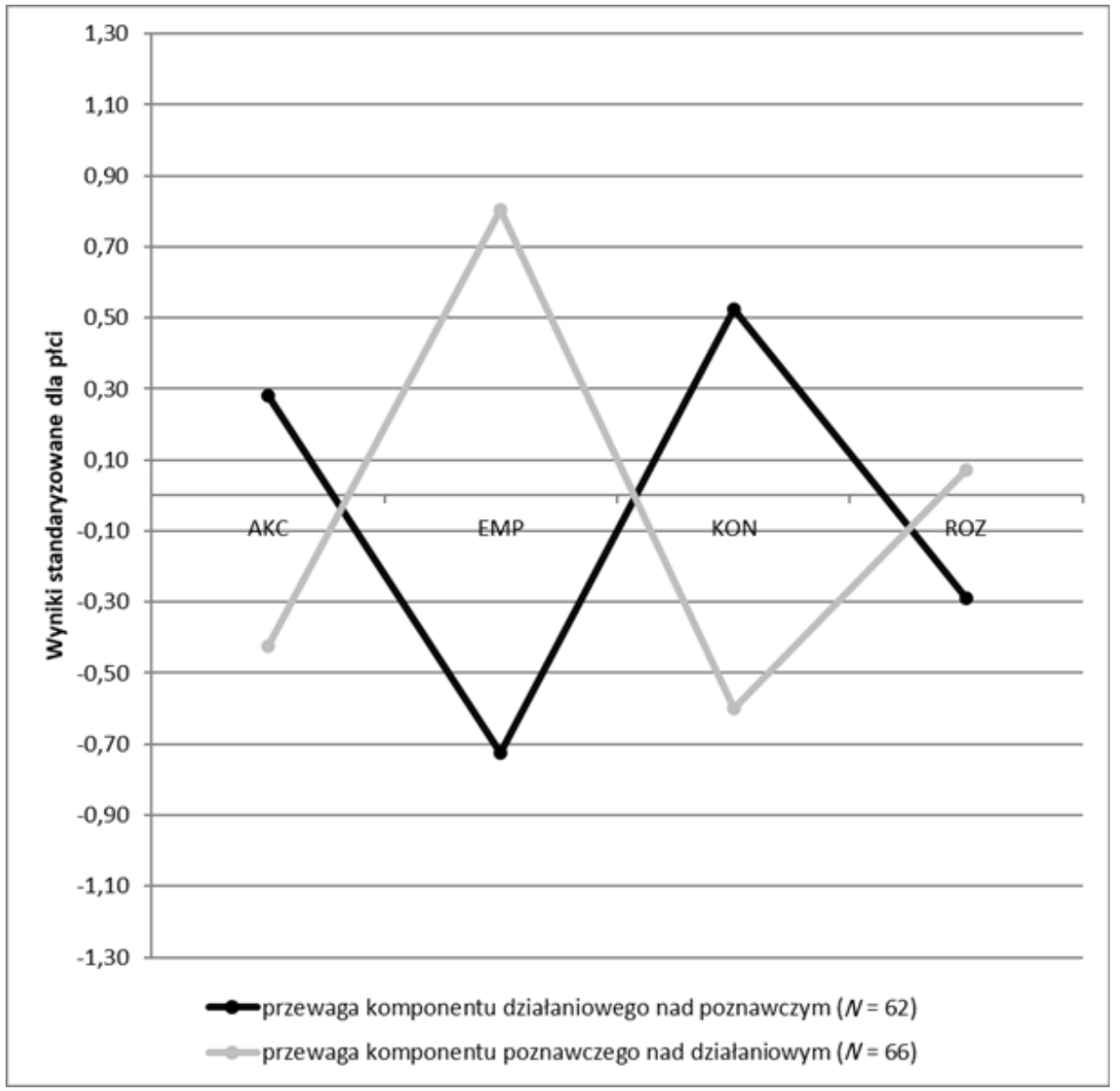

Rysunek 5. Uśrednione profile poznawczej i działaniowej inteligencji emocjonalnej u mężczyzn.

Adnotacja. Skale PKIE: AKC - akceptowanie; EMP - empatia; KON - kontrola; ROZ - rozumienie.

Z powyższych rysunków można wywnioskować, że kobiety jak i mężczyźni z przewagą komponentu działaniowego inteligencji emocjonalnej uzyskali wyższe wyniki w zakresie akceptacji emocji i kontroli emocjonalnej. Z kolei obie płcie charakteryzujące się przewagą komponentu poznawczego inteligencji emocjonalnej uzyskały wyższe rezultaty w obrębie empatii i rozumienia emocji. Przy czym ciekawy jest fakt, że większe rozbieżności 
w wynikach pomiędzy osobami reprezentującymi przewagę komponentu działaniowego a osobami reprezentującymi przewagę komponentu poznawczego wystąpiły w grupie mężczyzn. U kobiet różnice w poziomie poszczególnych zdolności między osobami reprezentującymi działaniową lub poznawczą inteligencję emocjonalną były zdecydowanie mniejsze.

\subsection{Dyskusja}

Przeprowadzone badania potwierdziły obie przyjęte hipotezy dotyczące różnic międzypłciowych w odniesieniu do inteligencji emocjonalnej. Kobiety uzyskały wyższe niż mężczyźni wyniki w zakresie inteligencji emocjonalnej doświadczeniowej, zwłaszcza w zakresie jej czynnika poznawczego związanego z rozumieniem emocji innych ludzi. Z kolei mężczyźni uzyskali wyższe od kobiet wyniki w obrębie inteligencji emocjonalnej strategicznej, zarówno w zakresie czynnika poznawczego, jak i czynnika działaniowego. Różnice nie są jednak duże (efekt płci jest mały). Płeć zatem nie tyle różnicuje ogólny poziom inteligencji emocjonalnej, co jest zmienną, która w pewnym stopniu wpływa na posiadany profil inteligencji emocjonalnej.

Większe zdolności w zakresie inteligencji emocjonalnej doświadczeniowej u kobiet (czyli zdolność do empatii oraz zdolność do akceptowania, wyrażania i wykorzystywania własnych emocji w działaniu) pozwalają im m.in. na łatwość i trafność rozpoznawania emocji u innych ludzi, a także na adekwatną ekspresję emocjonalną. Sprawia to, że kobiety są odbierane jako bardziej emocjonalne niż mężczyzni (bo łatwiej przychodzi im ujawnianie tego, co czują), a także sprawniej od nich radzą sobie w kontaktach interpersonalnych z emocjami innych osób (zatem inteligencja emocjonalna interpersonalna przypuszczalnie będzie u nich wyższa niż u mężczyzn).

Mężczyźni natomiast - mający większe zdolności w zakresie inteligencji emocjonalnej strategicznej - lepiej sobie radzą z kontrolą, rozumieniem i uświadamianiem sobie własnych emocji (zatem inteligencja emocjonalna intrapersonalna przypuszczalnie będzie u nich wyższa niż u kobiet). Mężczyznom łatwiej przychodzi zarządzanie własnymi uczuciami, co może wiązać się u nich z większym poczuciem własnej skuteczności w obszarze inteligencji emocjonalnej, skutkującej ich większą wiarą, że mogą własne emocje doskonalić, modyfikować, korzystać ze strategii umożliwiających zmianę uczuć oraz szacować skuteczność tych strategii. 
Najbardziej prawdopodobnym wyjaśnieniem różnic międzypłciowych w zakresie inteligencji emocjonalnej jest układ czynników biologicznych, ewolucyjnych i społeczno-kulturowych.

Wyjaśnienie biologiczne, jakie się nasuwa w związku z tym tematem, odnosi się do różnic w budowie mózgów kobiet i mężczyzn. Obszary odpowiedzialne za emocje w kobiecych mózgach są większe niż w męskich (np. Gur, Gunning-Dixon, Bilker, Gur, 2002), a także występują różnice w aktywności mózgowej w zależności od płci (Jaušoviec, Jaušoviec, 2005). Biologiczny punkt widzenia tłumaczy wrodzone zadatki kobiet do większej wrażliwości na emocje innych jako część ich biologicznego wyposażenia do roli macierzyńskiej.

Kobiety są, statystycznie rzecz ujmując, temperamentalnie bardziej reaktywne emocjonalnie, co oznacza u nich zarazem większą wrażliwość i mniejszą odporność emocjonalną (Zawadzki, Strelau, 1997). Wysoka reaktywność kobiet częściej może zatem osiągać wartość krytyczną, powyżej której intensywność reagowania emocjonalnego jest ponadoptymalna; stąd być może mniejsze zdolności kobiet w zakresie regulacji emocji i mniejsza ich stabilność emocjonalna. Ponadto kobiety wykazują w obrębie temperamentu większą perseweratywność od mężczyzn, co przejawia się u nich większą potrzebą refleksji nad emocjami doświadczanymi przez siebie i innych. Dotyczy to zwłaszcza negatywnych doświadczeń emocjonalnych, co do których mężczyźni reagują unikając koncentrowania na nich uwagi, zaś kobiety częściej reagują silną ruminacją i analizowaniem przyczyn nieprzyjemnych uczuć (Nolen-Hoeksema, 1987). Niektórzy badacze piszą też o większej wrażliwości sensorycznej kobiet w ogóle (Kimura, 2006; Moir, Jessel, 1993), a nie tylko w obszarze percepcji bodźców słuchowych, o czym była mowa wcześniej. Jeśli faktycznie tak jest, to tłumaczyłoby to większą sprawność kobiet w wychwytywaniu subtelnych sygnałów społecznych w postaci komunikatów niewerbalnych nadawanych za pomocą tonu głosu czy wyrazu twarzy (por. Hall, Matsumoto, 2004).

Na bazie teorii ewolucji i etologii można przypuszczać, że kobiety w toku ewolucji wykształciły szczególną wrażliwość na emocje. Zostały w ten sposób wyposażone w zdolności odczytywania, rozumienia i regulowania emocji u innych, gdyż ich posiadanie zwiększało szanse na przeżycie potomstwa i jego prawidłowy rozwój. Nawiązując do pytania o korzenie takiej składowej inteligencji emocjonalnej jak empatia, w zakresie której kobiety 
wykazują przewagę nad mężczyznami, trudno rozstrzygnąć, czy to czynniki wewnętrzne, czy też środowiskowe grają tu pierwszoplanową rolę (Pinker, 2009). Istnieją silne argumenty na rzecz biologicznych podstaw większego wyczuwania przez kobiety emocji innych ludzi, które pojawiają się nad długo przed tym, zanim kobieta przyswoi sobie wiedzę płynącą z kultury otoczenia o rolach płciowych. Dziewczynki już w okresie niemowlęcym (a więc wtedy, kiedy trudno byłoby mówić o wpływie oczekiwań kulturowych na ich zachowanie) przejawiają takie cechy jak częstsze nawiązywanie kontaktu wzrokowego, czy też większa empatia okazywana najbliższym.

Uwarunkowania różnic międzypłciowych z perspektywy społeczno-kulturowej można tłumaczyć tym, że proces socjalizacji związany z kulturowymi stereotypami ról płciowych może przebiegać odmiennie u każdej z płci (np. LaFrance, Banaji, 1992; Saarni, 1999). Jest to związane z odmiennymi stylami wychowywania dzieci różnej płci, a także z przekazem społecznym nakazującym chłopcom ukrywanie niektórych emocji (np. emocji smutku: „chłopaki nie płaczą"). Istnieją badania potwierdzające wpływ oddziaływań socjalizacyjnych na rozwój niektórych aspektów inteligencji emocjonalnej, takich jak np. ekspresja emocji (Chaplin, Cole, Zahn-Waxler, 2005), która w większym stopniu podlega socjalizacji, niż samo przeżywanie emocji (Fischer, 2000; Kring, Gordon, 1998). Z badań Scharfe (2000) wynika, że matki wyrażają więcej pozytywnych uczuć w stosunku do dziewczynek, zaś więcej negatywnych - w stosunku do chłopców. Nierówność w edukacji emocjonalnej dziewczynek i chłopców skutkuje większą biegłością kobiet w odczytywaniu werbalnych i niewerbalnych komunikatów emocjonalnych płynących z mimiki twarzy czy tonu głosu, większą ekspresją emocjonalną i lepszym komunikowaniem stanów uczuciowych. Mężczyźni z kolei są wychowywani do powściągliwości ekspresji emocjonalnej. Chłopcy specjalizują się w deprecjonowaniu emocji związanych ze słabością, takich jak poczucie winy, strachu czy bólu (Brody, Hall, 1993). Większą sprawność kobiet w rozpoznawaniu ekspresji mimicznej tłumaczy się też ich niższą pozycją społeczną, która sprawia, że zabiegając o przychylność mężczyzn, uważnie śledzą ich wyraz twarzy w poszukiwaniu przejawów akceptacji lub jej braku (np. Snodgrass, 1992). Czynnikiem kulturowym, jaki ma znaczenie $w$ rozwijaniu inteligencji emocjonalnej, jest to, że rodzice częściej rozmawiają z dziewczynkami na temat uczuć, częściej je motywują do ich wyrażania, więc kobiety „od małego” mają w tym zakresie niejako większe 
doświadczenie niż mężczyźni, którzy, jeszcze jako chłopcy, mają mniejsze wsparcie i zachętę ze strony rodziców w kierunku werbalizowania emocji (Brody, Hall, 1993; Fivush, Brotman, Buckner, Goodman, 2000).

Kobiety, pełniące role opiekuńcze wobec innych, a przez to koncentrujące się bardziej niż mężczyźni na przeżyciach emocjonalnych innych ludzi, są motywowane w toku socjalizacji do rozwijania opiekuńczości, altruizmu i wrażliwości interpersonalnej. Stąd kobiety są bardziej skupione na ekspresji emocjonalnej i odczytywaniu komunikatów emocjonalnych. Od mężczyzn bardziej wymaga się koncentracji zadaniowej oraz orientacji na odnoszenie sukcesów, przy równoczesnej kontroli emocjonalnej (ułatwiającej realizację celów).

Skoncentrowanie mężczyzn i kobiet na odmiennych celach i zainteresowaniach można $\mathrm{z}$ jednej strony tłumaczyć biologią, z drugiej zaś kulturą. Niezależnie od tego, jakie jest źródło tych odmienności, jedno jest pewne: w konsekwencji mężczyźni są w swoim myśleniu bardziej nastawieni na przedmiot (object-oriented), podczas gdy kobiety są bardziej zorientowane na osobę (person-oriented). Znajduje to m.in. wyraz w bardziej twórczym myśleniu mężczyzn, kiedy mają do czynienia z problemami związanymi z określonym przedmiotem lub jego wyobrażeniem, podczas gdy kobiety są bardziej wnikliwe w analizowaniu sytuacji wynikających ze stosunków interpersonalnych i wykazują więcej pomysłowości w sytuacjach interakcji społecznych. Takie ukierunkowanie obu płci to nic innego, jak zainteresowania i trening odmiennych podtypów inteligencji ogólnej, a co za tym idzie - inteligencji emocjonalnej. Większa koncentracja kobiet na sprawach konkretnych życia codziennego, zaś mężczyzn na zagadnieniach ogólnych znajduje wyraz także w ich funkcjonowaniu emocjonalnym.

Przekładając to na „język Epsteinowski”: bycie jednocześnie w tym samym momencie na poziomie bezpośredniego systemu przetwarzania informacji i pośredniego systemu przetwarzania informacji nie jest możliwe. Możliwe jest jedynie szybkie przechodzenie z jednego do drugiego pod warunkiem posiadania takiej cechy jak elastyczność. Zatem jeśli „częściej się przebywa w określonym miejscu", to nabywa się i rozwija bardziej cechy z nim związane. Tłumacząc to na interesującą nas tu kwestię różnic międzypłciowych: przeciętna kobieta, częściej korzystająca z zasobów intuicyjnego systemu przetwarzania, będzie bardziej rozwijała te aspekty inteligencji emocjonalnej, które wchodzą w jego zakres (percepcja emocjonalna 
i wykorzystywanie emocji w działaniu), zaś standardowy mężczyzna, częściej korzystający z zasobów racjonalnego systemu przetwarzania, będzie bardziej rozwijał te komponenty inteligencji emocjonalnej, które do niego się odnoszą (rozumienie emocji i regulacja emocjonalna). Zatem kobiety będą przejawiały wyższą inteligencję emocjonalną doświadczeniową, zaś mężczyźni - inteligencję emocjonalną strategiczną. Być może jednak takie myślenie jest obarczone błędem poznawczym nadmiernej generalizacji, bo trzeba zachować w świadomości to, że „nieprzeciętne” kobiety czy „nieprzeciętni” mężczyźni mogą odbiegać od tak naszkicowanego układu zdolności inteligencji emocjonalnej.

W kolejnym rozdziale przyjrzymy się temu, jak środowisko, w jakim wzrastamy - praktycznie już od najwcześniejszego dzieciństwa - może warunkować rozwijanie się naszych zdolności emocjonalnych. 


\section{Rozdział 5.}

\section{Środowiskowe uwarunkowania rozwoju inteligencji emocjonalnej}

Badacze, niezależnie od sposobu pojmowania inteligencji emocjonalnej, żywią na ogół przekonanie o tym, że nie jest ona dyspozycją wrodzoną, lecz jest nabywana i rozwijana wraz z rozwojem człowieka dzięki doświadczeniom. Doświadczenia te są uwarunkowane, z jednej strony, cechami środowiska, w którym jednostka żyje i rozwija się, z drugiej zaś - cechami temperamentu wpływającymi na intensywność, poziom i rodzaj aktywności (będącej jednym ze źródeł doświadczeń) podejmowanej przez jednostkę. Jakość i rodzaj doświadczeń kształtujących inteligencję emocjonalną zależą zatem zarówno od czynników zewnętrznych, jak i wewnętrznych, o których będzie mowa w niniejszym rozdziale.

\subsection{Rola środowiska rodzinnego w rozwoju inteligencji emocjonalnej}

Większość badaczy inteligencji emocjonalnej jest zgodna co do kluczowej roli rodziny dla rozwoju emocjonalnego jednostki, zwłaszcza w pierwszych latach życia (np. Goleman, 1997; Mayer, Salovey, 1997). W sposób spektakularny potwierdziły to badania, w których, za pomocą metody potencjałów wywołanych, porównywano reakcje na twarze u małych dzieci wychowywanych w instytucjach opiekuńczych i dzieci z grupy kontrolnej, wychowywanych w rodzinach (Parker, Nelson, 2005). Okazało się, że deficyt w zakresie typowych doświadczeń będących udziałem dziecka wychowywanego w rodzinie upośledza dojrzewanie funkcji mózgowych odpowiedzialnych za rozwój zdolności do rozpoznawania ekspresji mimicznej. Dzieci 
wychowywane w instytucjach nie posiadały typowej asymetrii aktywności mózgu, która zazwyczaj towarzyszy przetwarzaniu informacji dostarczanych przez twarze, polegającej na większej aktywności prawej niż lewej półkuli. Świadczy to o opóźnieniu procesu specjalizacji korowej, która stanowi podstawę rozwoju zdolności do spostrzegania emocji.

Drogi wpływu czynników rodzinnych na kształtowanie się i rozwój inteligencji emocjonalnej opierają się na takich samych mechanizmach, na jakich bazują wszelkie inne oddziaływania środowiskowo-wychowawcze. Do mechanizmów tych należą: obserwacja i modelowanie wzorców zachowań występujących w rodzinie w ustrukturyzowanych i nieustrukturyzowanych sytuacjach (źródłem są rodzice, rodzeństwo oraz inni członkowie rodziny), bezpośrednie uczenie się (polecenia, nakazy i zakazy, wskazówki, rady itp.), wzmocnienia pozytywne i negatywne (nagrody i kary) w odniesieniu do zachowań wyrażających emocje (Matthews i in., 2002; Zeidner, 2008). Środowisko ma również wpływ na kształt dokonującego się w nim treningu społeczno-emocjonalnego, jakiemu podlega dziecko, poprzez kształtowanie warunków aktywności. Rodzina może stymulować aktywność jednostki, dostarczając bodźców, które mogą ją wywołać, podtrzymać, czy też jej przeszkodzić (Matczak, 2005). Dostarcza ona wzorce, przekazuje dziecku wiedzę oraz stawia mu wymagania (Matczak, 2003).

Rodzina jest tym rodzajem środowiska, które najwcześniej zaczyna wpływać na człowieka, a także przez długi czas pozostaje najważniejszym źródłem oddziaływania na jednostkę. Można by nawet zaryzykować stwierdzenie, że jej oddziaływanie - zgodziliby się z tym zapewne wszyscy psychoterapeuci - towarzyszy człowiekowi w pewnym sensie (a czasem i dosłownie, w przypadku osób nie opuszczających rodziny pochodzenia) przez całe życie. Rodzina to niejako pierwszy teren zdobywania i rozwijania umiejętności społeczno-emocjonalnych, które potem dziecko może generalizować także na inne środowiska, w jakich zaczyna funkcjonować. Znaczenie zasobów, jak i obciążeń rodzinnych (które nadal mogą stanowić trudność w dorosłym życiu jednostki), to wątki szeroko poruszane w psychologii, pojawiące się np. w modelu międzypokoleniowym rodziny (np. Bowen, 1978), czy w teorii przywiązania (Bowlby, 2007). Według Bowlby’ego w zależności od tego, jaki styl przywiązania wytworzy się u dziecka na bazie jego pierwszych interakcji z rodzicami (głównie z matką), taki będzie się także u niego aktywizował w późniejszych kontaktach interpersonalnych 
z innymi osobami (Marchwicki, 2006). Należy jednak pamiętać, że kwestię stylu przywiązania u dziecka można widzieć bardziej jako jeden z wczesnych przejawów rozwijającej się inteligencji emocjonalnej, aniżeli czynnik ją warunkujący, bowiem jakość i typ przywiązania tworzą się w interakcji matki z dzieckiem, a więc zależą zarówno od właściwości zachowania matki, jak i samego dziecka (Matczak, 2005).

Brak więzi z rodzicami odzwierciedlony w stylu przywiązania innym niż tzw. bezpieczny (ufny) styl przywiązania (np. lękowo-ambiwalentnym lub unikającym) może przekładać się na postawę nieufności u dziecka wobec emocji, które będą w tym przypadku postrzegane jako zagrażające lub też na postawę traktującą sferę emocjonalną w sposób bagatelizujący, jako nieistotną (Denham i in., 2003). Jak nietrudno się domyślić, żadna z tych postaw nie będzie sprzyjała pełnemu rozwojowi nie tylko emocjonalnemu, ale, co za tym idzie, również osobowościowemu małego człowieka. Niektórzy określają ten rodzaj postawy jako tzw. „pra-nieufność” wobec świata, w przeciwieństwie do postawy „pra-zaufania” (Frielingsdorf, 1997), co sugerowałoby, że poczucie bycia przyjętym lub odrzuconym od samego poczęcia niejako „stygmatyzuje” człowieka na resztę jego życia i ma konsekwencje daleko wykraczające poza samą tylko sferę rozwoju emocjonalnego. Postawy „pra-zaufania” lub „pra-nieufności” są tu rozumiane jako nieświadomy, emocjonalny rdzeń nastawienia do życia, powstały na podstawie informacji pozytywnych i negatywnych przekazywanych przez ojca i matkę w najwcześniejszej fazie rozwoju. Informacje te są tzw. kluczowymi przekazami, będącymi nośnikiem akceptacji naszego życia lub jej braku. W przypadku przekazu negatywnego mogą się one przejawiać w postaci nie tylko dezadaptacyjnych, ale wręcz destrukcyjnych dla jednostki schematów osobistych (Young, Klosko, 2012; Young, Klosko, Weishaar, 2015), które z pewnością nie służą optymalnemu funkcjonowaniu jednostki w obszarze jej emocjonalności, a zatem również w zakresie związanym $\mathrm{z}$ inteligencją emocjonalną.

Czynnikiem „rodzinnym” ważnym dla kształtowania się „ufnego przywiązania”, a także samej inteligencji emocjonalnej, jest wrażliwość na potrzeby i emocje dziecka. Brak takiej wrażliwości, np. u matek cierpiących na depresję, może być przyczyną deficytów w zakresie samokontroli i efektywności kontaktów społecznych u ich dzieci (Goodman, Brogan, Lynch, Fielding, 1993). 
Badania Piekarskiej (2004) pokazały, że zachowania wspierające rozwój inteligencji emocjonalnej ze strony rodziców (szczególnie matek), takie jak np. okazywanie zrozumienia dla emocji dziecka czy wspieranie go w samodzielnym rozwiązywaniu problemów, dodatnio korelują z poziomem inteligencji emocjonalnej dziecka. Przy tym ważne jest, żeby ze strony rodziców nie występowały jednocześnie zachowania niewspierające, jak np. oskarżanie, bagatelizowanie czy podejmowanie decyzji za dziecko, ponieważ ich pojawienie się nie jest kompensowane przez zachowania wspierające. Także badania Zhou i współpracowników (2002), dotyczące małych dzieci (w wieku od drugiego do piątego roku życia), potwierdziły, że ciepłe wsparcie ze strony rodziców (zwłaszcza matek) wpływa na pozytywny rozwój dziecka, jego poziom wrażliwości na potrzeby innych i ogólny proces socjalizacji. Istnieje wiele innych badań, które potwierdzają, że klimat rodzinny, który można określić jako ciepły (tzw. ciepło rodzinne, którego nie należy mylić z nadopiekuńczym „ciepełkiem”) pozytywnie koreluje z rozwojem społeczno-emocjonalnym dziecka (np. Davies, Cummings, 1994).

Emocjonalna interakcja pomiędzy dziećmi a rodzicami lub innymi opiekunami ma wpływ na rozwój obszarów mózgu odpowiedzialnych za emocjonalną świadomość i regulację (Taylor, Parker, Bagby, 1999). Neuronalna podstawa regulacji emocji może zostać zaburzona, jeśli interakcja dziecka z ważnymi osobami przebiega w niewłaściwy sposób (Schore, 2001). Dziecko uczy się funkcjonowania emocjonalnego obserwując i naśladując rodziców, stąd to oni właśnie stanowią dla niego inspirację i model do naśladowania. Problemy rodziców w sferze emocjonalnej, takie jak np. nieumiejętność w obrębie ekspresji emocjonalnej, nieradzenie sobie $\mathrm{z}$ trudnymi emocjami czy też mało konstruktywne próby radzenia sobie z nimi poprzez represję stanowią negatywny wzorzec, który dziecko najprawdopodobniej będzie powielać (jako jedyny dostępny, zwłaszcza w okresie wczesnego dzieciństwa). Na przykład, dzieci, w obecności których rodzice lub inni bliscy członkowie rodziny miewają częste napady złości, są narażone na przyswajanie niewłaściwych modeli samoregulacji (Salovey, Bedell, Detweiler, Mayer, 2005). Odwrotnie - rodzice empatyczni, otwarcie mówiący o swoich emocjach, uznający ich ważność w życiu, będą stanowić pozytywny wzór dla własnych dzieci, co już od momentu narodzin da im dobry start dla rozwoju inteligencji emocjonalnej. Dzieci empatycznych rodziców z reguły same są empatyczne, ponieważ uczą się tego przez 
doświadczenie. Inteligentni emocjonalnie rodzice występują nie tylko jako „dostarczyciele" wzorców prawidłowego reagowania emocjonalnego, ale też, jak można sądzić, podejmują oddziaływania wychowawcze korzystne dla rozwoju zdolności i kompetencji emocjonalnych dziecka. Z kolei dzieci niedojrzałych emocjonalnie i społecznie rodziców same przejawiają trudności w funkcjonowaniu społeczno-emocjonalnym.

Duże znaczenie ma ekspresywność rodziny (zwłaszcza matek) przejawiająca się w częstości i intensywności wyrażania emocji w środowisku domowym (Nixon, Watson, 2001; Scharfe, 2000), gdyż to właśnie ekspresywne zachowania rodziców są dla dziecka źródłem wiedzy o emocjach i wzorców do naśladowania. Badania pokazują tutaj jednoznacznie korzystne znaczenie ujawniania emocji pozytywnych, natomiast w odniesieniu do ekspresji emocji negatywnych uzyskane wyniki są sprzeczne - wskazujące zarówno na lepsze, jak i gorsze rozpoznawanie emocji przez dzieci matek cechujących się silną ekspresją emocji „negatywnych”.

Ważnym aspektem emocjonalnej atmosfery domu rodzinnego jest również to, w jaki sposób rodzice reagują na emocjonalną ekspresywność dziecka - czy dziecko może „być sobą” w tej sferze, czy też np. z powodu komunikacji w systemie rodzinnym opartej na podwójnym wiązaniu, musi „adaptacyjnie" zrezygnować z wyrażania (a nawet świadomego przeżywania) w sposób autentyczny uczuć, których doświadcza (Nicolosi, 2011). Karanie przez rodziców wyrażania negatywnych emocji przez dzieci ma ujemny wpływ na regulację emocjonalną (Eisenberg i in., 1999). Taki układ emocjonalno-komunikacyjny w rodzinie często prowadzi do represji emocji u dziecka (niestety, wypierając trudne emocje, pozbawiamy się też możliwości przeżywania tych pozytywnych czy przyjemnych), co w rezultacie sprawia, że jednostka zostaje odcięta od materiału emocjonalnego, na bazie którego rozwija się inteligencja emocjonalna. Zatem ważną kwestią w rodzinnym układzie wpływów na rozwój inteligencji emocjonalnej wydaje się zachęcanie dziecka do wyrażania emocji, zarówno pozytywnych, jak i negatywnych, oraz uczenie go różnicy między emocjami i ich ekspresją, które są potencjalnie szkodliwe dla innych, od tych, które takie nie są.

Kolejnym ważnym elementem wpływów rodziny na rozwój inteligencji emocjonalnej jest wyważenie pomiędzy udzielaniem wsparcia dziecku a przyzwoleniem na autonomię, co przejawia się w jasno sprecyzowanych oczekiwaniach wobec dziecka i stosowanych kryteriach wzmocnień, 
połączonych z wiarą w możliwości dziecka, sprzyjającą rozwojowi jego kompetencji społeczno-emocjonalnych (Denham, Renwick, Holt, 1991). Na dziecko niekorzystnie wpływa zarówno nadopiekuńczość, jak i - z drugiej strony - rygoryzm ze strony rodziców; obie te postawy niosą ryzyko wystąpienia u niego aleksytymii (Maruszewski, Ścigała, 1998). Dla jednego z kluczowych aspektów inteligencji emocjonalnej, jakim jest samoregulacja emocjonalna, ważne okazały się takie czynniki (pozytywnie z nią korelujące) jak pozostawianie dziecku pewnej autonomii połączone ze wsparciem i zachętą ze strony rodziców (Grolnick, Ryan, 1989). Badania Boreckiej-Biernat (1995) świadczą o tym, że istotny jest stopień swobody, jaki dają dziecku rodzice w zakresie podejmowanych działań: nadmierna opiekuńczość sprzyja występowaniu nieśmiałości u chłopców w sytuacji ekspozycji społecznej. Badania Plopy (1983) pokazują, że nadmierna ochrona córek przez rodziców skutkuje nerwowością, agresywnością i zawziętością u tych dziewcząt.

Dla nabywania wiedzy emocjonalnej przez dziecko istotną kwestią jest to, czy rodzice rozmawiają z nim o emocjach: nazywają je, wyjaśniają ich genezę i skutki - przyczyny i konsekwencje (Denham, 1998). Dzięki rozmowie dziecko może strukturalizować sobie własne doświadczenia emocjonalne, co procentuje rozwojem kontroli emocjonalnej (rozumieniem i regulowaniem emocji własnych oraz adekwatnym reagowaniem na emocje innych). Badania Denham i Aurebach (2005) pokazały, że korzystny wpływ mają zwłaszcza pytania zachęcające dziecko do odczytywania emocjonalnej treści zachowań, np. w trakcie oglądania filmu, a także wyjaśnianie emocji. Niekorzystny wpływ zaś mają wypowiedzi wartościujące emocje (np. wyśmiewające je).

Wyniki badań przeprowadzonych przez Korol (2017) pokazały, że dla inteligencji emocjonalnej ważne okazały się takie cechy rodziny pochodzenia jak zrównoważona spójność, zrównoważona elastyczność, efektywna komunikacja oraz zadowolenie z życia rodzinnego. Zrównoważona spójność to pojęcie charakteryzujące system rodzinny, którego członkowie mają bliskie więzi emocjonalne i który cechuje się posiadaniem półprzepuszczalnych granic, jest empatyczny, otwarty, przy jednoczesnym zachowaniu miejsca na przestrzeń prywatną. Zrównoważona elastyczność oznacza zdolność rodziny do reagowania na zmiany, dostosowania się do nich przez wykształcanie nowych, skuteczniejszych strategii rozwiązywania problemów. 
Oczywiście niekorzystny wpływ środowiska rodzinnego, choć istotny, nie determinuje przecież do końca „losów” inteligencji emocjonalnej u jednostki. W wieku przedszkolnym i późniejszym szansą na wyrównanie deficytów domu rodzinnego w zakresie inteligencji emocjonalnej może być kontakt z dobrym pedagogiem czy wychowawcą, jak też z rówieśnikami, chociaż - i tu znów wracamy do punktu wyjścia - to rodzice decydują o możliwości kontaktu dziecka $\mathrm{z}$ innymi osobami i akceptują lub nie adekwatną do wieku dziecka samodzielność w sytuacjach społecznych. W toku wychowania pomocne są takie metody oddziałujące na podopiecznego jak behawioralne wzmacnianie, modelowanie, psychoedukacja, odgrywanie ról społecznych czy inne formy treningu. W wieku dorosłym osoba może podjąć się wysiłku własnego rozwoju w obrębie inteligencji emocjonalnej np. poprzez różne formy treningu czy też, w formie głębokiej pracy nad sobą, poprzez psychoterapię (lub autopsychoterapię) w celu „skontaktowania się" $\mathrm{z}$ własnymi zasobami emocjonalnymi (odblokowania, „uwolnienia” i zaktywizowania emocjonalnej części ,ja”), niezbędnymi dla wzrostu inteligencji emocjonalnej.

\subsection{Wpływ postaw i stylów rodzicielskich na inteligencję emocjonalną}

Środowisko rodzinne często opisuje się do celów badań za pomocą takich kategorii jak postawy rodzicielskie czy style wychowania. Postawa jest względnie stałym nastawieniem, sposobem odnoszenia się do dziecka, obejmującym komponenty: poznawczy, dążeniowy i afektywny (Braun-Gałkowska, 1985, 1992; Plopa, 2008a, 2008b; Ziemska, 1973, 1986), zaś styl to preferowany przez rodziców zbiór konkretnych środków/sposobów oddziaływania w toku wychowania, który jest w pewnym sensie konsekwencją postawy rodzicielskiej. Często pojęcia postawy i stylu bywają używane zamiennie (np. Borecka-Biernat, 1995; Field, 1996; Rembowski, 1972; Ryś, 1992; Ziemska, 1973). W literaturze psychologicznej można spotkać się z różnymi koncepcjami postaw rodzicielskich. Koncepcje te uwzględniają różne komponenty postaw rodziców. Na przykład, podstawowe postawy w koncepcji Kannera (1937, za: Przetacznik-Gierowska, Włodarski, 1998) to: akceptacja i miłość, jawne odrzucanie, perfekcjonizm i przesadna opiekuńczość; w koncepcji Slatera (za: Plopa, 2008): uzależnianie i separowanie 
się, ciepło i chłód, tolerancja i brak tolerancji oraz pobłażliwość i surowość; w koncepcji Plopy (2008a, 2008b): akceptacja, odrzucenie, autonomia, niekonsekwencja, nadmierna ochrona i nadmierne wymagania; w koncepcji Ziemskiej (1973): akceptacja, współdziałanie, rozumna swoboda i uznanie praw dziecka (postawy pozytywne) oraz odtrącanie, unikanie, nadmierne wymaganie i nadmierne chronienie (postawy negatywne); w koncepcji Braun-Gałkowskiej (1992): bliskość, opieka, wymagania, normy. Jeśli chodzi o style wychowania, to najczęściej wyróżnianymi są style: demokratyczny, autokratyczny (autorytarny), liberalny (przyzwalający), nadopiekuńczy i odrzucający (np. Borecka-Biernat, 1995; Field, 1996; Plopa, 1983).

Badania empiryczne ujawniły wiele zależności pomiędzy postawami rodzicielskimi i stylami wychowania a inteligencją emocjonalną. I tak, np. badania Knopp (2007) ujawniły dodatni związek pomiędzy inteligencją emocjonalną dzieci a postawą kochającą rodziców, ujemny zaś - z postawą odrzucającą. Badania Martowskiej (2007) wskazują na to, że styl demokratyczny sprzyja nabywaniu przez dziecko kompetencji emocjonalnych. Nadmierne wymagania stawiane dziecku wiążą się z deficytami w jego funkcjonowaniu społecznym (Plopa, 1983). Przy tym stwierdzono silniejszy związek pomiędzy funkcjonowaniem społecznym dziecka a wymaganiami stawianymi przez rodzica przeciwnej płci.

Badania pod kierunkiem Matczak (2005) pokazały, że istnieje istotny, aczkolwiek niezbyt silny, związek pomiędzy inteligencją emocjonalną u młodych ludzi (uczniów, studentów) a czynnikami rodzinnymi: inteligencją emocjonalną rodziców i ujawnianymi przez nich w przeszłości postawami wobec dzieci (ocena retrospektywna). Wyniki wykazały większy wpływ inteligencji emocjonalnej, postaw i sposobów reagowania matek, niż ojców. Okazało się też, że czynniki rodzinne mają silniejszy wpływ na dziewczęta niż chłopców. Inteligencja emocjonalna dzieci wiąże się dodatnio z postawą kochającą (zwłaszcza matek), a ujemnie z postawą liberalną i odrzucającą. Reakcje rodziców sprzyjające rozwojowi inteligencji emocjonalnej, w świetle tych badań, to zachęcanie do refleksji i samodzielnego rozwiązywania problemów oraz zrozumienie dla przeżywanych przez dziecko emocji, zaś niesprzyjające to obwinianie dziecka i niedocenianie jego zasług oraz podsuwanie mu gotowych rozwiązań. Odnosiło się to do zachowań matek; w przypadku chłopców takie niesprzyjające zachowania ze strony ojców 
mogą sprzyjać inteligencji emocjonalnej (wystąpiła dodatnia korelacja), co tłumaczy się kompensującym wpływem silnego wówczas związku z matką. Łodygowska i Chęć (2019) podjęly badania wpływu postaw rodzicielskich na inteligencję emocjonalną w retrospektywnej ocenie dokonanej przez młodych dorosłych. Autorki uzyskały wyniki mówiące o pozytywnej zależności między postawami rodzicielskimi matek w zakresie akceptacji/odrzucenia i autonomii a inteligencją emocjonalną córek i ich zdolnością do wykorzystywania emocji w myśleniu i działaniu. Związek między akceptującą postawą matek a inteligencją emocjonalną synów okazał się tutaj niewielki.

Oddziaływania rodzinne mają zawsze charakter dwustronny. Zachowania rodziców wpływające na inteligencję emocjonalną dziecka zależą w pewnym stopniu także od cech samego dziecka, zwłaszcza od intensywności emocji, ekspresywności, jakości nastroju, czyli właściwości ujawnianych przez dziecko od narodzin i będących przejawami jego temperamentu. Wpływ środowiska rodzinnego na inteligencję emocjonalną zazębia się z wpływem, jaki na jej rozwój wywierają cechy osobowości danej jednostki, zwłaszcza charakteryzujący ją temperament, o czym będzie mowa w dalszej części pracy. 


\section{Rozdział 6.}

\section{Temperamentalne uwarunkowania inteligencji emocjonalnej}

\subsection{Inteligencja emocjonalna a różne cechy osobowości}

Sposób rozumienia inteligencji emocjonalnej w pewnym stopniu indukuje jej związki z osobowością. Silniejszych zależności należy oczekiwać tutaj $\mathrm{w}$ przypadku ujmowania inteligencji emocjonalnej w kategoriach cech osobowości niż w przypadku definiowania jej jako grupy zdolności. Była już o tym mowa, że sposób operacjonalizacji konstruktu wynika często (choć nie zawsze) ze sposobu jej definiowania. Inteligencja emocjonalna rozumiana „zdolnościowo” częściej jest operacjonalizowana za pomocą testów, zaś rozumiana "osobowościowo" - za pomocą kwestionariuszy.

Najpierw przyjrzyjmy się związkom inteligencji emocjonalnej z osobowością uzyskanym w badaniach kwestionariuszowych. Część naukowców zajmujących się inteligencją emocjonalną uważa, że nie tylko jest ona zależna od osobowości, ale wręcz stanowi zespół określonych jej cech (np. Bar-On, 1997, 2000; Petrides, Furnham, 2001, 2003). Istnieją badania wykazujące zależności między inteligencją emocjonalną a niektórymi cechami osobowości (np. Davies, Stankov, Roberts, 1998; Roberts, Zeidner, Matthews, 2001; Van der Zee i in., 2002). Jako ważne jawią się tu zwłaszcza takie cechy jak ekstrawersja-introwersja, neurotyczność, wrażliwość sensoryczna, reaktywność, otwartość na doświadczenia i lęk społeczny. Przy tym rozróżnienie, co jest cechą temperamentu, a co cechą samej osobowości, często nie jest ostre; np. cechy z modelu Wielkiej Piątki są powiązane z właściwościami układu nerwowego, który jest dla nich biologicznym 
podłożem, a więc równie dobrze mogłyby być potraktowane jako cechy temperamentu. W dalszej części pracy przyglądam się bliżej zależnościom pomiędzy inteligencją emocjonalną a osobowością i temperamentem.

W pracach empirycznych najczęściej doszukiwano się związku pomiędzy inteligencją emocjonalną a cechami osobowości z modelu Wielkiej Piątki. McCrae (2000) - jeden ze współautorów tego modelu - uważa, że komponenty inteligencji emocjonalnej traktowanej jako zbiór cech osobowości właściwie pokrywają się ze składem Wielkiej Piątki. Na przykład, występujący w modelu Big Five czynnik ekstrawersji jest wymieniany jako taka składowa inteligencji emocjonalnej w modelach „mieszanych” jak asertywność, lub też osobowościowy czynnik przewagi emocji pozytywnych jest określony w modelu inteligencji emocjonalnej u Bar-Ona (1997) jako optymizm. De Raad (2005) zauważył, że pytania narzędzi kwestionariuszowych do pomiaru inteligencji emocjonalnej i składowych Wielkiej Piątki zachodzą na siebie pod względem treści.

Komponenty osobowości uwzględnione w Pięcioczynnikowej Teorii Osobowości (McCrae, Costa, 2005) to: ekstrawersja, neurotyczność, sumienność, ugodowość i otwartość na doświadczenia. Wymiar ekstrawersjaintrowersja określa ilość i intensywność interakcji międzyludzkich, poziom aktywności, potrzebę stymulacji i zdolność do odczuwania pozytywnych emocji oraz cieszenia się życiem (Ashton, Lee, Paunonen, 2002; Oleś, 2003). McCrae i Costa (2005) podkreślają biologiczne podłoże ekstrawersji. Ekstrawertycy i introwertycy różnią się między sobą poziomem pobudzenia korowego - pierwsi wykazują niski poziom pobudzenia, co skutkuje ich chronicznym niedostymulowaniem, drudzy zaś wykazują wysoki poziom pobudzenia (dużą aktywowalność), co owocuje ich chronicznym przestymulowaniem. Implikuje to różnice między nimi w zakresie możliwości przetwarzania stymulacji oraz zapotrzebowania na nią, o czym będzie jeszcze mowa w dalszej części pracy (nawiązującej do Regulacyjnej Teorii Temperamentu). Przeprowadzano badania dotyczące związku pojęcia pokrewnego inteligencji emocjonalnej, jakim są kompetencje emocjonalne, a ekstrawersją. Kompetencje społeczne interesują nas tu o tyle, że są one warunkowane przez inteligencję emocjonalną; to ona bowiem determinuje, do jakiego poziomu jednostka może zwiększać swoje emocjonalne umiejętności (Jasielska, Leopold, 2000; Mayer, Salovey, 1997), a związek ten został potwierdzony wieloma badaniami (np. Charbonneau, Nicol, 2002; Lopes, 
Salovey, Cote, Beers, 2005; Martowska, 2011; Norman, Combs-Richardson, 2001). Badania dotyczące kompetencji społecznych pokazują, że ekstrawertycy, w porównaniu z introwertykami, wykazują większą i intensywniejszą aktywność werbalną, chętniej nawiązując kontakt z rozmówcą, częściej wyrażają pozytywny stosunek wobec innych oraz udzielają pozytywnej informacji zwrotnej dotyczącej ich zachowań, są bardziej ufni w stosunku do ludzi, bardziej bezpośredni w niewerbalnej komunikacji emocjonalnej, co przejawia się w żywości mimiki, gestykulacji, zróżnicowaniu intonacji głosu, zrelaksowanej postawie ciała (por. Christophel, 1990; Thomas, Richmond, McCroskey, 1994). Ekstrawertycy częściej posiadają rozleglejszą sieć wsparcia, a także częściej proszą innych o wsparcie - pomoc i radę (Szpitalak, Polczyk, 2009), są otwarci na bodźce społeczne oraz wpływają na swoje środowisko tak, by sprzyjało nawiązywaniu i podtrzymywaniu relacji z innymi (Argyle, 1999). Z kolei introwersja może mieć związek z niskimi kompetencjami społecznymi (Beatty, McCroskey, Heisel, 1998). Wiąże się to z niskimi możliwościami przetwarzania stymulacji, które mogą ograniczająco wpływać na społeczną aktywność introwertyków, a co za tym idzie - na mniejsze umiejętności społeczne w wyniku braku dostatecznego treningu społecznego.

Mimo to nie istnieje prosty związek pomiędzy ekstrawersją a inteligencją emocjonalną. Ekstrawertycy swoją dużą potrzebę stymulacji mogą zaspokajać bez konieczności wchodzenia w kontakty z innymi, np. poprzez uprawianie sportów ekstremalnych; poza tym mogą być oni, ze względu na niski poziom lęku i mniejszą koncentrację na bodźcach społecznych, bardziej powierzchowni w relacjach $\mathrm{z}$ innymi. Ekstrawersja nie musi więc być predyktorem wysokiej inteligencji emocjonalnej, co najwyżej może się wiązać z niektórymi jej komponentami. Introwertycy, z racji swoich właściwości, mogą bardziej starannie inwestować w swoje relacje społeczne, być bardziej skoncentrowani na partnerach interakcji, stąd charakter ich relacji interpersonalnych może być głębszy, co może przekładać się na niektóre aspekty inteligencji emocjonalnej, np. na poziom empatii.

Neurotyczność jest wymiarem określającym emocjonalne nieprzystosowanie, skłonność do przeżywania emocji negatywnych, dyskomfortu psychicznego, nierealistycznych idei, niepohamowanych pragnień, wrażliwość na stres (Zawadzki, Strelau, Szczepaniak, Śliwińska, 1998). Na przeciwnym biegunie znajduje się wymiar określający przystosowanie, opanowanie 
i stabilność emocjonalną. Prawdopodobnym podłożem biologicznym neurotyczności jest pobudliwość układu wegetatywnego. Neurotycy cechują się wysokim poziomem lęku przed dezaprobatą społeczną, brakiem przystosowania społecznego oraz tendencją do autoregulacji poprzez unikanie wyzwań interpersonalnych (Argyle, 1999; Leary, Kowalski, 2001). Osoby neurotyczne charakteryzują się także niskim poczuciem bezpieczeństwa, skłonnością do zamartwiania się oraz nieefektywną regulacją emocjonalną (Siuta, 2006). Badania wykazały, że neurotyczność jest związana z emocjonalnym stylem radzenia sobie ze stresem oraz z niskim poczuciem własnej skuteczności (Francis, 1993; Klonowicz, Cieślak, 2004). Neurotyczność może się też wiązać $\mathrm{z}$ nieśmiałością i zahamowaniem w relacjach $\mathrm{z}$ innymi (Milles, Hempel, 2004). Neurotyczność, w połączeniu z introwersją, może skutkować deficytami w relacjach interpersonalnych oraz niską satysfakcją z życia (Beatty i in., 1998; Hayes, Joseph, 2003; Lynn, Steel, 2006). Można w takim razie wyciągnąć wniosek, że neurotyczność jest cechą, która nie koresponduje $\mathrm{z}$ wysokim poziomem inteligencji emocjonalnej.

Ugodowość odnosi się do nastawienia wobec innych ludzi na kontinuum od współczucia aż po antagonizm w myślach, uczuciach i działaniu. Osoby ugodowe są ufne, wyrozumiałe, altruistyczne, ale też, przy skrajnym nasileniu tej cechy - zależne i konformistyczne. Niska ugodowość może się przejawiać w rysie makiawelistycznym osobowości, skłonności do manipulowania innymi i skutecznej realizacji własnych celów w kontakcie z innymi. Być może duża ugodowość sprzyja aspektom inteligencji emocjonalnej związanym z bliskimi relacjami interpersonalnymi, zaś niska jest bardziej korzystna w sytuacjach wymagających zachowań asertywnych.

Sumienność obejmuje wysoki stopień organizacji, wytrwałości i motywacji jednostki w dążeniu co celu. Opozycję do niej stanowi wysoki poziom niezdyscyplinowania i niezorganizowania. Można przypuszczać zatem, że sumienność jest czynnikiem sprzyjającym inteligencji emocjonalnej.

Otwartość na doświadczenie to wymiar obejmujący aktywne poszukiwanie nowych doświadczeń, ciekawość poznawczą i tolerancję nowości. Przypuszczalnie duża otwartość oznacza gotowość nowych doświadczeń społecznych, a te z kolei rodzą emocje będące materiałem, na którym bazuje inteligencja emocjonalna (por. koncepcja Matczak w dalszej części pracy), stąd otwartość ta może mieć wpływ na rozwój inteligencji emocjonalnej. 
W wielu badaniach, w których doszukiwano się związku cech osobowości w ujęciu modelu Big Five z inteligencją emocjonalną, była ona mierzona kwestionariuszem Bar-Ona (Austin, Saklofske i in., 2005; Brackett, Mayer, 2003; Dawda, Hart, 2000; Petrides, Furnham, 2001, 2003), testem Schutte i współpracowników (Austin, Saklofske i in., 2005; Brackett, Mayer, 2003; Jaworowska, Matczak, 2008; Saklofske i in., 2003; Schute i in., 1998), kwestionariuszem Trait Meta-Mood Scale (Warwick, Nettelbeck, 2004), kwestionariuszem Trait Emotional Intelligence Questionnaire-Short Form (Szczygieł, Jasielska, Wytykowska, 2015), a także innymi narzędziami (Gannon, Ranzijn, 2005; Van der Zee i in., 2002). Najsilniejsze związki w wymienionych wyżej badaniach ujawniły się pomiędzy inteligencją emocjonalną a neurotycznością: były to korelacje ujemne w granicach od $-0,19$ do $-0,73$, oraz inteligencją emocjonalną a ekstrawersją: korelacje dodatnie w granicach od 0,28 do 0,56. Jeśli chodzi o pozostałe cechy z modelu Wielkiej Piątki, to inteligencja emocjonalna korelowała $\mathrm{z}$ nimi dodatnio, ale mniej konsekwentnie i nieco słabiej.

W badaniach włoskich podjęto próbę określenia w jakim stopniu inteligencja emocjonalna mierzona kwestionariuszem The Trait Emotional Intelligence Questionnaire (TEIQue-SF) może pośredniczyć pomiędzy cechami osobowości mierzonymi The Big Five Questionnaire (BFQ) a optymizmem i nadzieją. Wyniki potwierdziły istotną rolę zdolności emocjonalnych jako mediatora w szczególności pomiędzy stabilnością emocjonalną, ugodowością i ekstrawersją a optymizmem oraz pomiędzy ekstrawersją, stabilnością emocjonalną i sumiennością a nadzieją (Di Fabio i in., 2018). Inteligencja emocjonalna okazała się być również zmienną pośredniczącą między czterema wymiarami osobowości (ekstrawersja, otwartość na doświadczenie, życzliwość i sumienność) a wdzięcznością (Szcześniak, Rodzeń, Malinowska, Kroplewski, 2020).

Podejmowano też poszukiwania badawcze dotyczące inteligencji emocjonalnej mierzonej TEIQue-SF (Trait Emotional Intelligence Questionnaire-Short Form) oraz wymiarów osobowości z NEO-FFI. Uzyskane w nich korelacje były z reguły silne, zarówno jeśli chodzi o związek ogólnej inteligencji emocjonalnej z neurotycznością $(-0,59$ do $-0,66)$, jak i z pozostałymi cechami: ekstrawersją $(0,51-0,54)$, otwartością na doświadczenia $(0,24-0,32)$, ugodowością $(0,34-0,38)$ i sumiennością $(0,45-0,48$; Petrides i in., 2011; Vernon, Villani, Schermer, Petrides, 2008). 
Ten sam kierunek korelacji w odniesieniu do związków inteligencji emocjonalnej z osobowością pojawił się w innych badaniach (Andi, 2012), w których inteligencja emocjonalna była mierzona kwestionariuszem MYEIT ( $\mathrm{Ma}$ laysian Youth Emotional Intelligence Test), z tym że uzyskane ujemne korelacje między ogólnym poziomem inteligencji emocjonalnej a neurotycznością okazały się nieistotne; jedyna istotna zależność, jaka ujawniła się pomiędzy neurotycznością a inteligencją emocjonalną, dotyczyła tego jej komponentu, którym jest zdolność do regulacji emocji $(-0,16)$. Ponadto inteligencja emocjonalna istotnie korelowała dodatnio z ekstrawersją $(0,55)$, otwartością na doświadczenia $(0,51)$, ugodowością $(0,59)$ i sumiennością $(0,60)$.

W badaniach, w których uwzględniono typy inteligencji emocjonalnej: intrapresonalną i interpersonalną (Lyusin, 2006), mierzone Emln Questionnaire Scale, oraz czynniki Big Five, okazało się, że obie korelowały dodatnio z ekstrawersją (inter: 0,42; intra: 0,38) i ugodowością (inter: 0,23; intra: 0,34); ponadto inteligencja emocjonalna intrapersonalna korelowała ujemnie z neurotycznością $(-0,54)$, zaś interpersonalna - dodatnio z otwartością na doświadczenie $(0,15)$.

O tym, że związek inteligencji emocjonalnej z osobowością ujawnia się już w dzieciństwie, mogą świadczyć wyniki badań, w których grupę badawczą stanowiły dzieci w wieku 8-13 lat. Również tutaj korelacje pomiędzy inteligencją emocjonalną (mierzoną TEIQue-CF: Trait Emotional Intelligence Questionnaire - Child Form) a cechami osobowości (Big Five Questionnaire) przyjęły najczęściej spotykany układ: neurotyczność wykazała ujemny związek z inteligencją emocjonalną $(-0,42)$, zaś dodatni - z ekstrawersją $(0,40)$, ugodowością $(0,47)$, sumiennością $(0,44)$ oraz otwartością na doświadczenia $(0,38)$ (Russo i in., 2012).

$\mathrm{W}$ innych badaniach, wykraczających poza model Big Five (Davies i in., 1998), w których zastosowano kilka różnych kwestionariuszy do pomiaru osobowości oraz inteligencji emocjonalnej, wskaźniki kwestionariuszowe inteligencji emocjonalnej wchodziły w ujemny związek z czynnikami neurotyczności i psychotyczności, zaś w dodatni - z czynnikami ekstrawersji i ugodowości.

Weryfikowano też związek inteligencji emocjonalnej mierzonej kwestionariuszem Bar-Ona (Petrides, Furnham, 2001) lub Schutte i współpracowników (Matczak, 2004a, 2005) z cechami osobowości z modelu PEN Eysencka oraz z czynnikami, które wyodrębniono na podstawie 16-czynnikowego 
kwestionariusza Cattella (Newsome i in., 2000; O'Connor, Little, 2003). W pierwszym przypadku ujawniła się dodatnia korelacja inteligencji emocjonalnej z ekstrawersją $(0,24-0,41)$, a ujemna - z neurotycznością $(-0,31)$ i psychotycznością $(-0,14$ do $-0,34)$; w drugim, dodatnia - z ekstrawersją $(0,34 ; 0,46)$, samokontrolą $(0,36)$, niezależnością $(0,43 ; 0,44)$; zaś ujemna z lękiem $(0,76 ; 0,77)$.

Innymi zmiennymi osobowościowymi, jakie uwzględniono w badaniach nad inteligencją emocjonalną, były lęk oraz potrzeba aprobaty społecznej. W badaniach polskich (Jaworowska, Matczak, 2008) stwierdzono związek pomiędzy inteligencją emocjonalną mierzoną INTE a lękiem jako cechą $(-0,19)$, lękiem jako stanem $(-0,27)$, a także potrzebą aprobaty społecznej $(0,22)$.

Znaleziono także ujemne związki (od -0,26 do -0,67) między inteligencją emocjonalną mierzoną kwestionariuszem Bar-Ona a wynikami klinicznych skal podstawowego inwentarza osobowości Jacksona (Hemmati, Mills, Kroner, 2004).

W obszarze zainteresowań niektórych badaczy znalazł się także związek pomiędzy inteligencją emocjonalną traktowaną jako cecha (TEIQue) a tzw. „czarną triadą" cech osobowości: narcyzmem, makiawelizmem i psychopatią (np. Jonason, Webster, 2010; Paulhus, Williams, 2002). Okazało się, że inteligencja emocjonalna korelowała dodatnio $z$ narcyzmem $(0,20$ i 0,22$)$ oraz ujemnie z makiawelizmem $(-0,29 \mathrm{i}-0,37)$ i psychopatią $(-0,21 \mathrm{i}-0,24$; Petrides, Vernon, Schermer, Veselka, 2011).

$\mathrm{W}$ badaniach dotyczących zależności inteligencji emocjonalnej z reakcją na indukowany stres stwierdzono, że niski poziom inteligencji emocjonalnej jest związany ze stanami zamartwiania się, niepokoju oraz unikającym stylem radzenia sobie (Matthews i in., 2006).

Nieco inaczej przedstawiają się wyniki badań, w których inteligencja emocjonalna mierzona była testowo. Głównie zajmowano się w nich cechami osobowości z modelu Wielkiej Piątki oraz z eysenckowskiego PEN, rzadziej czynnikami osobowości Cattella. Korelacje pomiędzy nimi a wynikami testów MEIS lub MSCEIT często okazywały się niewielkie lub nieistotne (Brackett, Mayer, 2003; Bracket i in., 2004; Ciarrochi i in., 2000; Day, Carroll, 2004; Lopes i in. 2003; Roberts i in., 2001; Schulte, Ree, Carretta, 2004; Warwick, Nettelbeck, 2004). Korelacje dodatnie, które stwierdzono dotyczyły głównie ugodowości $(0,24-0,30)$ oraz otwartości $(0,17-0,25)$, 
rzadziej - sumienności $(0,23)$. Z wyżej wymienionych autorów jedynie Schulte i współpracownicy doszukali się ujemnego związku inteligencji emocjonalnej z neurotycznością $(-0,28)$.

W innych badaniach ugodowość okazała się być moderatorem i mediatorem wpływu inteligencji emocjonalnej na makiawelizm. Osoby o wysokiej inteligencji emocjonalnej i zarazem wysokim poziomie ugodowości rzadziej ujawniały tendencję do manipulowania innymi niż osoby o wysokiej inteligencji emocjonalnej i niskim poziomie ugodowości (O’Connor, Athota, 2013).

Z kolei O'Connor i Little (2003) wykazali ujemny związek $(-0,24)$ pomiędzy inteligencją emocjonalną (mierzoną MSCEIT) a lękiem (kwestionariusz Cattella). Co ciekawe, w powyższych badaniach nie stwierdzono związku inteligencji emocjonalnej z ekstrawersją. Zakładając, że testy mierzą raczej poznawczy aspekt inteligencji emocjonalnej: rozpoznawanie i rozumienie emocji zarówno własnych i cudzych, można by wyciągnąć wniosek, że ekstrawersja i charakterystyczna dla niej aktywność społeczna oraz towarzyskość nie mają znaczenia dla zdolności z obszaru inteligencji emocjonalnej „poznawczej”.

Inteligencja emocjonalna jest moderatorem pomiędzy uczuciem gniewu a wyrażaniem go w postaci agresji. Osoby o mniejszych zdolnościach emocjonalnych częściej przejawiają zachowania agresywne, co według badaczy jest spowodowane u nich tendencją do ruminacji, których treścią są doznane krzywdy. Rozpamiętywanie przeszłych traum jest próbą poradzenia sobie z doznawanymi, silnymi emocjami (Garcia-Sancho, Salguero, Fernandez-Berrocal, 2016).

W polskich badaniach Matczak i współpracowników (2005) inteligencję emocjonalną mierzono za pomocą testów MEIS oraz SIE-T, zaś cechy osobowości - kwestionariuszem EPQ-R. Wykazały one istotne związki psychotyczności z rezultatami zarówno MEIS $(-0,13$ do $-0,22)$, jak i SIE-T $(-0,38)$ oraz neurotyczności z wynikami MEIS $(-0,13)$. W przypadku ekstrawersji nie znaleziono istotnych zależności.

Brackett i Mayer (2004) przeprowadzili analizę czynnikową, w efekcie której inteligencja emocjonalna mierzona MSCEIT znalazła się we wspólnym czynniku z ugodowością i inteligencją werbalną. Czynnik ten okazał się nieskorelowany z dwoma innymi, w skład których weszły pozostałe cechy osobowości z modelu Big Five - samoopisowe wskaźniki inteligencji 
emocjonalnej oraz poczucie dobrostanu. Rzadko stwierdzane były korelacje inteligencji emocjonalnej mierzonej testowo z ekstrawersją. Ciarrochi i in. (2000) znaleźli związek pomiędzy inteligencją emocjonalną mierzoną testowo (MEIS) a ekstrawersją $(0,26)$, oprócz tego - również z otwartością emocjonalną $(0,24)$ oraz samooceną $(0,31)$.

Ciekawe badania dotyczyły relacji inteligencji emocjonalnej (MEIS) z mechanizmami obrony ego (DSQ, The Bond Defense Style Questionnaire). Ich wyniki nie są jednoznaczne: wykazały skorelowanie inteligencji emocjonalnej $z$ adaptacyjnymi mechanizmami obronnymi ego oraz wiedzy emocjonalnej zarówno z adaptacyjnymi, jak i nieprzystosowawczymi mechanizmami obrony ego (Pellitteri, 2002). Jednakże można tu sobie zadać pytanie, jaki jest kierunek związku: mechanizmy obronne wpływają na inteligencję emocjonalną, czy też inteligencja emocjonalna warunkuje przystosowanie $\mathrm{w}$ zakresie stosowanych obron ego.

Taki aspekt osobowości jak aleksytymia - konstrukt, który można nazwać „przeciwieństwem” inteligencji emocjonalnej, jest z nią ujemnie skorelowany (np. Naghavi, Redzuan, Mansor, 2010; Parker, Taylor, Bagby, 2001; Schutte i in., 1998). Aleksytymia jest definiowana jako brak zdolności do rozumienia, identyfikowania i wyrażania emocji, co skutkuje także brakiem efektywnej regulacji emocjonalnej (por. Wagner, Lee, 2007). Aleksytymicy przejawiają brak empatii (czyli istotnego składnika inteligencji emocjonalnej) oraz problemy z nawiązywaniem relacji (Davies i in., 1998).

Związek inteligencji emocjonalnej z osobowością najczęściej badano w odniesieniu do cech osobowości z modelu Wielkiej Piątki, a więc z cechami, które uważane są za odpowiadające cechom temperamentu. W badaniach na ten temat najbardziej konsekwentnie pojawiały się związki pomiędzy inteligencją emocjonalną a neurotycznością (korelacje ujemne) oraz inteligencją emocjonalną a ekstrawersją (korelacje dodatnie). Z pozostałymi cechami osobowości z modelu Wielkiej Piątki: sumiennością, ugodowością i otwartością na doświadczenia, inteligencja emocjonalna korelowała (dodatnio) nieco słabiej i mniej konsekwentnie.

W dalszej części pracy poruszam kwestię tego, jak taka cecha osobowości jak temperament warunkuje rozwój inteligencji emocjonalneji oraz jak kształtują się relacje pomiędzy poszczególnymi zdolnościami inteligencji emocjonalnej a cechami temperamentu. 


\subsection{Rola temperamentu w rozwoju inteligencji emocjonalnej}

Większość naszych cech psychoemocjonalnych rozwija się na podłożu biologicznej bazy, jaką są cechy naszego układu nerwowego, czyli temperament. Zatem również, kiedy rozpatrujemy inteligencję emocjonalną i jej poziom nie sposób nie odwołać się w swoich poszukiwaniach dotyczących jej źródeł do właściwości temperamentalnych jednostki. Nasze społeczne, kulturowe czy edukacyjne doświadczenia osadzają się zawsze na naszej biologicznej naturze, stąd wynika ważność czynników biologicznych i wrodzonych dla rozwoju inteligencji emocjonalnej. Wielu badaczy uważa, że sama inteligencja emocjonalna nie jest cechą wrodzoną, lecz nabywaną, kształtowaną i rozwijaną stopniowo w toku rozwoju człowieka (np. Goleman, 1997; Mayer, Salovey, 1999). Takie myślenie jest uzasadnione, jeśli przyjmiemy założenie, że inteligencja emocjonalna stanowi jeden z rodzajów inteligencji skrystalizowanej, która kształtuje się i rozwija w ciągu całego życia na bazie potencjału wrodzonej, biologicznie uwarunkowanej inteligencji płynnej (koncepcja inteligencji Cattella [1971]). Niezależnie od koncepcji, zgodnie z którą rozumie się temperament, nie ulega wątpliwości, że istnieje związek pomiędzy zdolnościami emocjonalnymi a temperamentem (np. Denham, 1998; Saarni, 1999; Strelau, 1992). Badania sugerują, że to właśnie niektóre cechy temperamentu (np. intensywność emocjonalna, towarzyskość, poziom aktywności) mogą mieć wpływ na rozwój zdolności emocjonalnych (Halberstadt, Denham, Dunsmore, 2001; Rothbart, Derryberry, 1981). Wpływ ten ujawnia się od wczesnego dzieciństwa - już bardzo małe dzieci są zdolne do dostrzegania sygnałów emocjonalnych, różnicowania ich oraz konstruktywnego na nie reagowania, co wskazuje na to, że kompetencje emocjonalne są do pewnego stopnia niezależne od rozwoju poznawczego (Izard, 2001).

Wiele cech temperamentu uwzględnianych w różnych koncepcjach temperamentu można interpretować jako właściwości określające możliwości jednostki. Dotyczy to takich cech jak wrażliwość, zdolność przetwarzania stymulacji, łatwość uczenia się i adaptacji oraz łatwość kontroli własnego zachowania (Matczak, 2004b). Z drugiej strony, temperamentalnie określone możliwości człowieka kształtują jego preferencje: skłonni jesteśmy zwykle do podejmowania aktywności, która odpowiada naszym możliwościom 
oraz do unikania działań, co do których przypuszczamy, że sobie z nimi nie poradzimy. Rozwój inteligencji emocjonalnej jest warunkowany aktywnością jednostki, zwłaszcza aktywnością społeczną. To dzięki kontaktom interpersonalnym jednostka uczy się rozpoznawać, rozumieć i przewidywać emocje zarówno cudze, jak i własne (inni są zwierciadłem naszych emocji oraz źródłem informacji zwrotnej w tej materii). Kontakty społeczne wymuszają na nas naukę kontrolowanej ekspresji własnych emocji. Temperament, warunkując aktywność społeczną, warunkuje w ten sposób rozwój samej inteligencji emocjonalnej.

Dla zilustrowania tezy o związku inteligencji emocjonalnej z temperamentem warto przytoczyć model Zeidnera i jego współpracowników, ilustrujący mechanizmy wpływu temperamentu na rozwój emocjonalny jednostki. Jest to wielowarstwowy, rozwojowy „model inwestycyjny” inteligencji emocjonalnej (Zeidner, Matthews, Roberts, MacCann, 2003). Uwzględnia on trzy poziomy przetwarzania informacji oraz zachowań adaptacyjnych emocjonalnie (Zeidner, 2008). Pierwszy z tych poziomów stanowią biologicznie uwarunkowane cechy temperamentu, np. emocjonalność, towarzyskość czy poziom aktywności. Według autorów poziom ten jest platformą i infrastrukturą dla dalszego emocjonalnego uczenia się i rozwoju.

Kolejnym poziomem modelu inwestycyjnego jest, oparte na regułach, uczenie się kompetencji emocjonalnych. Uczenie się kluczowych umiejętności emocjonalnych zachodzi poprzez strategie behawioralne, np. modelowanie zachowania emocjonalnego, czy wzmocnienia. Dziecko nabywa kompetencje emocjonalne i społeczne poprzez oparte na przywiązaniu relacje z rodzicami oraz z innymi ważnymi osobami, co następuje w dynamicznej interakcji $z$ temperamentem. Konfrontacja $z$ ustrukturyzowanymi i nieustrukturyzowanymi sytuacjami w otoczeniu uczy dziecko reguł przyczynowo-skutkowych odnoszących się do rozpoznawania i wyrażania emocji.

Trzecim poziomem modelu Zeidnera i in. (2003) jest rozwój strategicznej regulacji emocji, który jest osiągany dzięki bezpośredniemu treningowi i uczeniu się od ważnych postaci procesu socjalizacyjnego. Trening rodzicielski polega na werbalnym analizowaniu emocji złożonych, ukierunkowaniu uwagi dziecka na związek między danym wydarzeniem a jego emocjonalnymi konsekwencjami, pomaganiu dziecku w zrozumieniu jego reakcji i zarządzaniu nimi, dzieleniu problemów pojawiających się w interakcjach 
z innymi na mniejsze fragmenty, łatwiejsze do opanowania (por. Zeidner, 2008). Rozwój strategicznej regulacji emocji również może być modulowany przez temperament.

Koncepcją, na której opieram się w mojej pracy i która w czytelny i spójny sposób opisuje mechanizmy wpływu temperamentu na rozwój inteligencji emocjonalnej jest koncepcja Matczak (2004a). Punkt wyjścia stanowi oczywiste stwierdzenie, że istota inteligencji emocjonalnej polega na łączeniu emocji z poznaniem - emocje są poddawane refleksji poznawczej oraz same wspomagają tę refleksję. Innymi słowy, rozwój inteligencji emocjonalnej jest stymulowany poprzez współdziałanie procesów emocjonalnych i poznawczych. Rozwój ten dokonuje się w takich sytuacjach, w których działanie człowieka sprzyja powstawaniu emocji, a zarazem - powstawaniu refleksji nad nimi. Dwa rodzaje ludzkiej aktywności mają tu szczególne znaczenie: aktywność zadaniowa i społeczna. Wykonywanie zadań jest nastawione na wyznaczone cele, a oszacowanie ich ważności dla jednostki ma swoje odzwierciedlenie w emocjach - to one zawierają ocenę wartościującą zdarzenia z punktu widzenia celów podmiotu, stąd wniosek, że aktywność zadaniowa stanowi silne źródło emocji. Z drugiej zaś strony wymaga ona zintensyfikowanej kontroli poznawczej. Aktywność społeczna $\mathrm{z}$ kolei dotyczy kontaktów społecznych, w których inni ludzie stanowią silne źródło emocji oraz odzwierciedlają emocje i dostarczają sprzężeń zwrotnych, a to przyczynia się do pogłębienia samopoznania i wiedzy emocjonalnej jednostki. Według autorki inteligencja emocjonalna rozwija się wtedy, kiedy jednostka angażuje się w aktywność zadaniową lub społeczną, co rodzi emocje (które zwrotnie wpływają na to zaangażowanie), przy czym zarówno podejmowana aktywność, jak i emocje, a zwłaszcza ich wzajemne relacje, są przedmiotem poznania (rysunek 6). Przyjmując, że rozwój jest efektem aktywności jednostki, nie sposób nie uznać tu istotnej roli temperamentu jako czynnika rozwojowego, który wpływa na cechy aktywności, takie jak jej intensywność, poziom i rodzaj (Matczak, 2004b). 


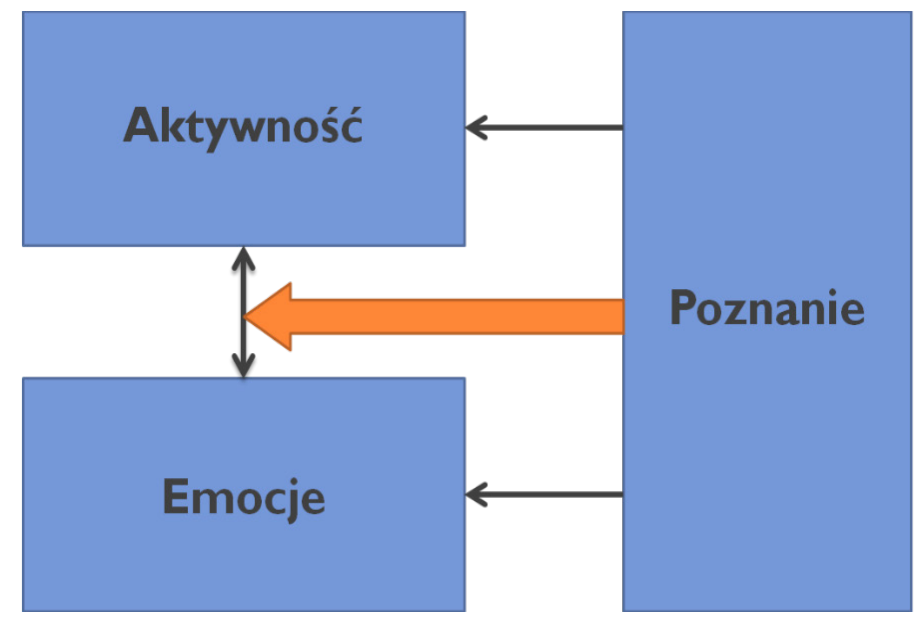

Rysunek 6. Mechanizm rozwoju inteligencji emocjonalnej w koncepcji Matczak (2004b).

Temperament wpływa, po pierwsze, na częstość i intensywność angażowania się w aktywność zadaniową i społeczną. Są one silnie stymulujące dla człowieka, stąd będą zapewne zależeć od temperamentalnie uwarunkowanych możliwości przetwarzania stymulacji i zapotrzebowania na stymulację, czyli od cech określanych przez Pawłowa (1952) jako wydolność, przez Eysencka (1970) - jako ekstrawersja, przez Zuckermana (1985, za: Strelau, 2002) - jako zapotrzebowanie na stymulację, zaś przez Strelaua $(1985,2002)$ - jako wytrzymałość i aktywność. Przemawiające za tym wyniki niektórych badań wykazały związek cech temperamentu stanowiących o dużych możliwościach przetwarzania stymulacji z zadaniowym stylem reagowania i odpornością na stres (Strelau, 1998; Szczepaniak, Strelau, Wrześniewski, 1996), aktywnym stylem samoregulacji (Eliasz, 1974) czy też orientacją na działanie (Marszał-Wiśniewska, 1999). Potwierdzają to również dane na temat aktywności społecznej osób ekstra- i introwertycznych (np. Eysenck, Eysenck, 1985).

Po drugie, cechy temperamentu warunkują samo powstawanie emocji wskutek aktywności zadaniowej i społecznej. Intensywność emocji jest wyznaczana przez wrażliwość i reaktywność emocjonalną.

Po trzecie, temperament ma znaczenie dla powstania czynników warunkujących możliwość autorefleksji, gdyż, będące istotą doświadczeń 
rozwijających inteligencję emocjonalną, współwystępowanie aktywności, emocji i poznania wymaga efektywnej regulacji pobudzenia. Mechanizmy temperamentu warunkują kontrolę poznawczą, która wymaga efektywnej regulacji pobudzenia, utrzymywania go na stosunkowo wysokim poziomie (co podtrzymuje działanie i towarzyszące emocje), ale też niedopuszczania do stanu ponadoptymalnego, który osłabiałby lub uniemożliwiał kontrolę. Sprzyjająca, czy wręcz niezbędna, jest tu optymalna intensywność emocji - dość duża, lecz nie na tyle, żeby zaburzać funkcjonowanie (co zależy od możliwości przetwarzania stymulacji, struktury temperamentu: zharmonizowanej lub niezharmonizowanej oraz „czynnika refleksji”).

Podsumowując: temperament, a zwłaszcza te jego cechy, które stanowią o wielkości zapotrzebowania na stymulację (temperamentalnie uwarunkowane preferencje) oraz o wrażliwości i łatwości kontroli (temperamentalnie wytyczone możliwości), wpływa na to, jakie działania podejmuje jednostka i którą sferę rozwija w związku z podejmowaną aktywnością (Matczak, 2002). Istnieją badania potwierdzające ten kierunek wnioskowania. $\mathrm{Na}$ przykład, badania Zawadzkiego i Strelaua (1997) podają, że osoby, które przeszły intensywny trening społeczny, różnią się pod względem struktury temperamentu od osób mających niewielką ilość doświadczeń społecznych. Taki wniosek stanowi teoretyczne założenie niniejszej pracy.

\subsection{Związki pomiędzy inteligencją emocjonalną a wybranymi cechami temperamentu}

Podjęto badania dotyczące zależności pomiędzy inteligencją emocjonalną a cechami temperamentalnymi rozumianymi zgodnie z Pawłowowską koncepcją temperamentu, jak również z interakcyjną teorią temperamentu Thomasa i Chess (1977). W badaniach tych posłużono się takimi narzędziami do pomiaru temperamentu jak: Kwestionariusz temperamentu PTS (Strelau, Zawadzki, 1998) oraz Zmodyfikowany kwestionariusz wymiarów temperamentu (DOTS-R; Windle, Lerner, 1986; polska adaptacja: Śliwińska, Zawadzki, Strelau, 1995). Inteligencja emocjonalna była w nich mierzona testem Skale Inteligencji Emocjonalnej - Twarze (SIE-T; Matczak i in., 2005) oraz testem MEIS (Mayer i in., 1997).

Wyniki badań testowych inteligencji emocjonalnej, w powiązaniu z parametrami temperamentu w ujęciu Pawłowa (por. Matczak 2004a; 2005; 
Matczak i in., 2005), świadczą o ujemnej korelacji inteligencji emocjonalnej z siłą układu nerwowego w zakresie procesu pobudzenia (czyli dużą wydolnością i małą wrażliwością; od $-0,16$ do $-0,28$ ) oraz z siłą układu nerwowego w zakresie procesu hamowania $(-0,15)$, a także o jej ujemnym związku z ruchliwością procesów nerwowych $(-0,14$ do $-0,21)$. W badaniach, w których poszukiwano zależności inteligencji emocjonalnej z cechami temperamentu w kontekście teorii Chess i Thomas, stwierdzono, że korelują one ze sobą słabo i niekonsekwentnie (Knopp, 2005). Na przykład, inteligencja emocjonalna korelowała $\mathrm{z}$ tendencją do zbliżania się - w zależności od zastosowanego testu - zarówno ujemnie, jak i dodatnio $(-0,16$ i 0,29). Ta niekonsekwencja dotyczyła też kierunku związku inteligencji emocjonalnej $\mathrm{z}$ regularnością snu $(-0,25$ i 0,14$)$ oraz regularnością codziennych nawyków $(0,14 \mathrm{i}-0,24)$. Ponadto we wspomnianych badaniach stwierdzono umiarkowany związek inteligencji emocjonalnej z aktywnością podczas snu $(0,31)$ oraz słaby związek z elastycznością $(0,17)$ i jakością nastroju $(0,14-0,15)$.

Badania kwestionariuszowe nad związkami inteligencji emocjonalnej z temperamentem w ujęciu Pawłowa przyniosły rezultaty odmienne od badań testowych (Jaworowska, Matczak, 2008; Matczak 2004a, 2005; Matczak, Knopp, 2019). W przeciwieństwie do tych ostatnich, kierunek uzyskanych związków inteligencji emocjonalnej z cechami temperamentu był dodatni. Ich wartość wynosiła odpowiednio: od 0,32 do 0,59 - w odniesieniu do ruchliwości procesów nerwowych, od 0,26 do 0,52 - w odniesieniu do siły układu nerwowego w zakresie pobudzenia oraz od 0,20 do 0,26 - w odniesieniu do siły układu nerwowego w zakresie hamowania. Ta ostatnia zależność nie ujawniła się w przypadku grupy badanych, jaką byli uczniowie (por. Jaworowska, Matczak, 2008). Uzyskane związki inteligencji emocjonalnej z ruchliwością procesów nerwowych (jak również wcześniej przytaczane - ze żwawością) zdają się sugerować, że plastyczność procesów nerwowych być może jest tą cechą, która charakteryzuje osoby o wysokim poziomie zarówno inteligencji emocjonalnej doświadczeniowej, jak i strategicznej (a także poznawczej i działaniowej).

W polskich badaniach (Szcześniak, Strochalska, 2019) dotyczących związków pomiędzy temperamentem mierzonym kwestionariuszem TEMPS-A (The Temperament Evaluation of Memphis, Pisa and San Diego Auto-questionnaire; Akiskal, Akiskal, 2005; por. Dembińska-Krajewska, Rybakowski, 2014), poczuciem koherencji (SOC - Sense Of Coherence) 
a inteligencją emocjonalną mierzoną kwestionariuszem INTE stwierdzono, że temperament depresyjny, cyklotymiczny, drażliwy i lękowy korelują ujemnie z inteligencją emocjonalną, zaś temperament hipertymiczny koreluje $\mathrm{z}$ nią dodatnio. Wniosek $\mathrm{z}$ tych badań jest taki, że inteligencja emocjonalna jest mediatorem pomiędzy wymiarami temperamentu a wszystkimi wymiarami SOC takimi jak zrozumiałość, zaradność, sensowność i globalna orientacja życiowa.

Nie było tu mowy o powiązaniach inteligencji emocjonalnej z cechami temperamentu w ujęciu Regulacyjnej Teorii Temperamentu, ponieważ im - jako że są szczególnie ważne z punktu widzenia pracy - chcę poświęcić osobny, kolejny rozdział.

\subsection{Cechy temperamentu w Regulacyjnej Teorii Temperamentu a inteligencja emocjonalna}

6.4.1. Regulacyjna Teoria Temperamentu. Koncepcją temperamentu, jaką przyjmuję w mojej pracy, jest Regulacyjna Teoria Temperamentu (RTT) stworzona przez Strelaua $(2002,2006)$. Akcentuje ona znaczenie temperamentu w determinowaniu preferencji jednostki i jej tendencji do angażowania się w określone rodzaje działań i sytuacji. Podstawowym mechanizmem jest tu regulacja poziomu pobudzenia związana $\mathrm{z}$ wielkością indywidualnego zapotrzebowania na stymulację (Strelau, 1982, 1992). Zgodnie z RTT temperament to zespół względnie stałych, pierwotnie biologicznie zdeterminowanych cech osobowości, które przejawiają się w formalnej charakterystyce zachowania, czyli w jego poziomie energetycznym oraz w jego parametrach czasowych. Podlega on powolnym zmianom, co spowodowane jest procesem dojrzewania oraz specyficznymi dla jednostki oddziaływaniami między genotypem a środowiskiem (Strelau, 1998).

Poziom energetyczny zachowania wyznaczają cztery parametry temperamentu: reaktywność emocjonalna, czyli tendencja do silnego reagowania na bodźce emocjogenne, połączona $\mathrm{z}$ dużą wrażliwością i małą odpornością emocjonalną; wytrzymałość, czyli zdolność do adekwatnego reagowania w sytuacjach wymagających długotrwałej lub wysokostymulującej aktywności lub też w warunkach silnej stymulacji zewnętrznej; wrażliwość sensoryczna, czyli zdolność do reagowania na bodźce zmysłowe o słabym nasileniu; aktywność, czyli tendencja do podejmowania zachowań 
o dużej wartości stymulacyjnej lub zachowań dostarczających stymulacji $\mathrm{z}$ otoczenia.

Temperamentalne czasowe parametry zachowania to z kolei: żwawość, rozumiana jako tendencja do szybkiego reagowania, przy utrzymywaniu wysokiego tempa aktywności, i łatwość zmiany zachowania w odpowiedzi na zmiany w otoczeniu (duża plastyczność zachowania) oraz perseweratywność, czyli tendencja do kontynuowania i powtarzania zachowań pomimo zaprzestania działania bodźców czy sytuacji wywołujących te zachowania (Zawadzki, Strelau, 1997).

Energetyczne cechy temperamentu mają wpływ na wybór sytuacji i form działania mających energetyczną wartość stymulacyjną: wytrzymałość na długość, intensywność pracy i tolerancja na silną stymulację fizyczną; reaktywność emocjonalna - na dużą wrażliwość emocjonalną vs. odporność emocjonalną na stres; aktywność - na zdolność do nawiązywania kontaktów i działania wśród ludzi, podejmowanie ryzyka i angażowanie się w różnorodne zajęcia; wrażliwość sensoryczna - na zdolność percepcji słabych bodźców i oceny mało intensywnych sygnałów (por. Zawadzki, Strelau, 1997).

Z kolei czasowe cechy temperamentu mają wpływ na wybór sytuacji i form działania w zależności od ich wartości stymulacyjnej, związanej z czynnikiem czasu (elastyczność działania, plastyczność myślenia, szybkość reagowania, zręczność).

Poszczególne cechy temperamentu, a także ich struktura, mają określone znaczenie adaptacyjne. Osoby o zharmonizowanej strukturze temperamentu wskazującej na duże możliwości przetwarzania stymulacji (wysoka wytrzymałość, wrażliwość sensoryczna i żwawość; niska reaktywność i perseweratywność) charakteryzują się dużymi możliwościami przystosowawczymi. Tej strukturze temperamentu wydaje się odpowiadać typ sangwiniczny z tradycyjnej typologii Hipokratesa-Galena. Osoby o zharmonizowanej strukturze temperamentu wskazującej na małe możliwości przetwarzania stymulacji (niska wytrzymałość, wrażliwość sensoryczna i żwawość; wysoka reaktywność i perseweratywność) charakteryzują się raczej małymi możliwościami przystosowawczymi. Struktura ta wydaje się odpowiadać typowi melancholicznemu. Osoby o niezharmonizowanej strukturze wskazującej na duże możliwości przetwarzania stymulacji (wysoka wytrzymałość; niska reaktywność i aktywność; niska lub przeciętna wrażliwość sensoryczna, 
żwawość i perseweratywność) charakteryzują się nieefektywną regulacją stymulacji i nastawieniem na ograniczenie zachowań rozładowujących w efekcie niskiego (nieoptymalnego) poziomu zwyczajowego pobudzenia. Taka struktura odpowiada flegmatycznemu typowi temperamentu. Osoby o niezharmonizowanej strukturze temperamentu wskazującej na małe możliwości przetwarzania stymulacji (niska wytrzymałość; wysoka reaktywność emocjonalna i aktywność; wysoka lub przeciętna wrażliwość sensoryczna, perseweratywność i żwawość) charakteryzują się nieefektywną regulacją stymulacji i nastawieniem na rozładowywanie wysokiego (nieoptymalnego) poziomu zwyczajowego pobudzenia. Zdaniem autorów kwestionariusza struktura ta odpowiada cholerycznemu typowi temperamentu (Zawadzki, Strelau, 1997).

Temperament w ujęciu RTT jest operacjonalizowany przez kwestionariusz Formalna charakterystyka zachowania - Kwestionariusz temperamentu (FCZ-KT; Zawadzki, Strelau, 1997).

Badania nad powiązaniami temperamentu, rozumianego zgodnie z koncepcją Regulacyjnej Teorii Temperamentu, a inteligencją emocjonalną realizowane były wyłącznie przez polskich badaczy. Ich wyniki przytaczam w kolejnym rozdziale.

\subsubsection{Potwierdzone empirycznie zależności pomiędzy tempera- mentem w ujęciu Regulacyjnej Teorii Temperamentu a inteligencją emocjonalną. $W$ badaniach polskich nad związkami między inteligencją emocjonalną a temperamentem w koncepcji Regulacyjnej Teorii Tempera- mentu zdolności emocjonalne były mierzone za pomocą narzędzi testowych i kwestionariuszowych. \\ Do pomiaru testowego inteligencji emocjonalnej korzystano $\mathrm{z}$ takich narzędzi jak: zadania wzorowane na wieloczynnikowej skali inteligencji emocjonalnej (por. MEIS; Matczak, 2005), Skala Inteligencji Emocjonalnej - Twarze (SIE-T; Matczak i in., 2005) oraz Test Rozumienia Emocji (TRE; Matczak, Piekarska, 2011; Piekarska, 2010). \\ Najbardziej konsekwentne związki, jakie stwierdzono pomiędzy testowo mierzoną inteligencją emocjonalną a temperamentem w ujęciu RTT, do- tyczyły takiej jego cechy jak wrażliwość sensoryczna. Uzyskane pomiędzy nimi zależności nie były jednak silne i plasowały się na różnym poziomie w zależności od zastosowanej miary testowej: od 0,13 do 0,21 (MEIS; por.}


Matczak, 2004a, 2005), 0,18 (SIE-T; Matczak i in., 2005) oraz 0,36 (TRE; Matczak, Piekarska, 2011).

Kolejnym parametrem temperamentu wyraźnie powiązanym $\mathrm{z}$ inteligencją emocjonalną okazała się być perseweratywność, aczkolwiek uzyskane związki nie dotyczyły wszystkich uzyskanych wyników. I tak: perseweratywność korelowała dodatnio z inteligencją emocjonalną na poziomie od 0,16 do 0,28 w przypadku kilku badań przeprowadzonych za pomocą zadań z MEIS (por. Matczak, 2004a, 2005); z kolei w przypadku badań, w których zastosowano SIE-T (Matczak i in., 2005) ujawnił się związek pomiędzy perseweratywnością a inteligencją emocjonalną jedynie na poziomie tendencji $(0,14)$. Natomiast w badaniach przeprowadzonych za pomocą TRE (Matczak, Piekarska, 2011) nie stwierdzono pomiędzy nimi istotnej zależności.

Zależność dodatnią pomiędzy reaktywnością emocjonalną a inteligencją emocjonalną $(0,17-0,18)$ znaleziono w niektórych (nie wszystkich) badaniach przeprowadzonych za pomocą MEIS. Nie stwierdzono jej natomiast w przypadku zastosowania innych testowych metod pomiaru.

Związek pozostałych parametrów temperamentu z inteligencją emocjonalną był jeszcze mniej konsekwentny i ujawnił się w pojedynczych badaniach. Żwawość korelowała pozytywnie dość wysoko z inteligencją emocjonalną $(0,36)$ w wynikach uzyskanych za pomocą TRE (Matczak, Piekarska, 2011); wytrzymałość korelowała ujemnie z inteligencją emocjonalną $(-0,17) \mathrm{w}$ jednym $\mathrm{z}$ badań przeprowadzonych za pomocą MEIS (por. Matczak, 2004a). Najsłabiej powiązaną z inteligencją emocjonalną mierzoną testowo okazała się być aktywność, w przypadku której związek z inteligencją emocjonalną ujawniły, jedynie na poziomie tendencji $(0,11)$, rezultaty uzyskane za pomocą testu TRE (Matczak, Piekarska, 2011).

Pomiar kwestionariuszowy powiązań inteligencji emocjonalnej z cechami temperamentu z RTT przeprowadzany był głównie za pomocą kwestionariusza INTE (Jaworowska, Matczak, 2008), będącego polską adaptacją kwestionariusza Schutte Self-Report Inventory for Emotional Intelligence (Schutte i in., 1998), oraz narzędzia PKIE (Jaworowska, Matczak, 2005).

Badania dotyczące inteligencji emocjonalnej mierzonej kwestionariuszowo miały czasem na celu nie tyle zweryfikowanie hipotezy o jej temperamentalnym podłożu, co bardziej wykazanie trafności samego konstruktu inteligencji emocjonalnej lub trafności narzędzi do jej pomiaru (por. Ciarrochi, Chan, Caputi i in., 2001). 
W przypadku badań, w których zastosowano do pomiaru inteligencji emocjonalnej narzędzia samoopisowe, uzyskano rezultaty wskazujące na zdecydowanie silniejsze i bardziej konsekwentne jej zależności z cechami temperamentu, niż miało to miejsce w przypadku badań przeprowadzonych za pomocą narzędzi testowych (por. Jaworowska, Matczak, 2008; Matczak, 2004a, 2005; Matczak i in., 2005).

W przypadku inteligencji emocjonalnej mierzonej kwestionariuszowo cechami temperamentu, które okazały się najsilniej z nią związane, okazały się aktywność i żwawość, a więc cechy, których wysoki poziom występuje u osób o dużych możliwościach przetwarzania stymulacji (pod warunkiem posiadania przez nie zharmonizowanej struktury temperamentu). Zarówno aktywność, jak i żwawość wykazały dodatnie związki z inteligencją emocjonalną. Badania wykazały, że jeśli chodzi o aktywność, w przypadku gdy do pomiaru inteligencji emocjonalnej zastosowano kwestionariusz INTE, były to związki rzędu od 0,19 do 0,48. W przypadku pomiaru inteligencji emocjonalnej za pomocą innego narzędzia - Kwestionariusza inteligencji emocjonalnej (KIE; Jaworowska, Matczak, 2001) uzyskano podobne związki pomiędzy aktywnością i inteligencją emocjonalną na poziomie od 0,34 do 0,49 . Żwawość wykazywała związki z inteligencją emocjonalną w badaniach za pomocą INTE na poziomie od 0,24 do 0,35 oraz nieco wyższe w badaniach za pomocą KIE - od 0,33 do 0,49. Uzyskane związki pomiędzy żwawością a inteligencją emocjonalną, które wystąpiły we wszystkich zbadanych grupach (uczniowie, studenci i dorośli), mogą świadczyć o tym, że wysoka inteligencja emocjonalna koresponduje $\mathrm{z}$ dużą plastycznością i giętkością zachowania oraz łatwością adaptowania się do zmian. Odnosząc to do koncepcji Epsteina, można powiedzieć, że elastyczność ta pozwala jednostce przechodzić plastycznie z jednego poziomu przetwarzania (bezpośredniego lub pośredniego) na drugi i korzystać efektywnie z zasobów inteligencji emocjonalnej, jakie są „ulokowane” na każdym z nich.

Reaktywność emocjonalna - cecha, której wysoki poziom jest związany z małymi możliwościami przetwarzania stymulacji, korelowała konsekwentnie ujemnie $\mathrm{z}$ inteligencją emocjonalną w większości przytaczanych badań: słabiej, w przypadku zastosowania INTE do pomiaru inteligencji emocjonalnej (od $-0,18$ do $-0,27$ ) i dość silnie w przypadku pomiaru inteligencji emocjonalnej za pomocą KIE (od $-0,58$ do $-0,69$ ). 
Związki wrażliwości sensorycznej z inteligencją emocjonalną ujawniły się tylko w przypadku poszukiwań badawczych z zastosowaniem kwestionariusza INTE (od 0,19 do 0,40), natomiast nie wystąpiły w przypadku zastosowania do pomiaru inteligencji emocjonalnej kwestionariusza KIE.

Cechą najsłabiej związaną z inteligencją emocjonalną w badaniach samoopisowych okazała się być wytrzymałość - związek pomiędzy nimi na umiarkowanym poziomie $(0,40)$ ujawniło tylko jedno $\mathrm{z}$ badań $\mathrm{z}$ zastosowaniem KIE (por. Matczak, 2004a).

Związki ostatniego z parametrów z RTT - perseweratywności z inteligencją emocjonalną - okazały się niekonsekwentne. W przypadku badań, w których inteligencja emocjonalna była operacjonalizowana za pomocą INTE, związki pomiędzy persewertywnością a inteligencją emocjonalną były dodatnie (od 0,21 do 0,28), zaś w przypadku zoperacjonalizowania inteligencji emocjonalnej za pomocą KIE były one ujemne (od -0,31 do -0,41).

$\mathrm{W}$ jednym z przeprowadzonych badań za pomocą INTE (por. Matczak, 2004a) poddano analizie osobno każdy z czynników INTE (czynnik 1 umiejętność wykorzystywania emocji do wspomagania myślenia i działania; czynnik 2 - umiejętność rozpoznawania emocji), stwierdzając odmienność ich korelatów temperamentalnych: tylko pierwszy - a więc ten dotyczący działaniowego aspektu inteligencji emocjonalnej - korelował dodatnio ze żwawością $(0,24)$ i ujemnie z reaktywnością emocjonalną $(-0,24)$, zaś tylko drugi - a więc ten dotyczący aspektu poznawczego inteligencji emocjonalnej - dodatnio z perseweratywnością $(0,21)$. Oba natomiast korelowały dodatnio z wrażliwością sensoryczną (kolejno 0,26 i 0,39) i z aktywnością (kolejno 0,48 i 0,19 ). Na postawie przytoczonych badań można wnioskować, że dwie cechy temperamentu najsilniej związane z kwestionariuszowo mierzoną inteligencją emocjonalną to żwawość i aktywność (łączny procent wyjaśnianej nimi wariancji wynosił 19\%).

W badaniach Matczak i Knopp (2019) zaobserwowano pozytywny związek pomiędzy wrażliwością sensoryczną i wytrzymałością a ogólną inteligencją emocjonalną, oraz ujemny związek pomiędzy perseweratywnością i reaktywnością emocjonalną a ogólną inteligencją emocjonalną. Zdolności strategicznej inteligencji emocjonalnej takie jak rozumienie i kontrola emocji były skorelowane dodatnio z wytrzymałością, zaś ujemnie - z perseweratywnością i reaktywnością emocjonalną. Dodatkowo zdolność rozumienia emocji okazała się być dodatnio związana z wrażliwością 
sensoryczną. W przypadku doświadczeniowej inteligencji jedynym jej znaczącym predyktorem okazała się być wrażliwość sensoryczna. Autorki porównały ze sobą osoby o małych i dużych możliwościach przetwarzania stymulacji pod względem inteligencji emocjonalnej. Kryterium wyodrębnienia tych grup był prezentowany poziom takich cech temperamentu jak wytrzymałość i reaktywność emocjonalna (niska wytrzymałość i wysoka reaktywność emocjonalna = małe możliwości przetwarzania stymulacji; wysoka wytrzymałość i niska reaktywność emocjonalna = duże możliwości przetwarzania stymulacji). Osoby o dużych możliwościach przetwarzania stymulacji charakteryzowały się wyższą ogólną inteligencją emocjonalną, a także wyższym poziomem komponentów strategicznej inteligencji emocjonalnej (rozumienie i kontrola emocji), w porównaniu z osobami o średnich i niskich możliwościach przetwarzania stymulacji. Nie stwierdzono różnic $\mathrm{w}$ inteligencji emocjonalnej pomiędzy osobami o średnich i niskich możliwościach przetwarzania stymulacji. Doświadczeniowa inteligencja emocjonalna i jej składowe nie były powiązane z możliwościami przetwarzania stymulacji. Według autorek brak różnic między grupami osób o średniej i niskiej zdolności przetwarzania stymulacji może sugerować, że możliwości przetwarzania stymulacji są zmienną progową, czyli taką, która zwiększa poziom strategicznej inteligencji emocjonalnej dopiero po osiągnięciu pewnego progu.

W dalszej części pracy przedstawiam badania własne nad związkami pomiędzy cechami temperamentu w ujęciu RTT a poziomem i profilem inteligencji emocjonalnej.

\subsection{Prezentacja wyników badań własnych}

6.5.1. Przyjęte założenia. Główne założenie przyjęte przeze mnie w celu zbadania powiązań między inteligencją emocjonalną a temperamentem opiera się na koncepcji rozwoju inteligencji emocjonalnej autorstwa Matczak (2004a). Koncepcja ta wyprowadzona jest z założenia Saloveya i Mayera głoszącego, że istota inteligencji emocjonalnej polega na łączeniu emocji z poznaniem, stąd rozwój inteligencji emocjonalnej jest stymulowany poprzez współdziałanie procesów emocjonalnych i poznawczych. Można przyjąć, że temperament wpływa na jednostkę na poziomie emocjonalnym (intensywność, rodzaj i częstotliwość doświadczanych emocji), 
behawioralnym (częstość i intensywność angażowania się w aktywność zadaniową i społeczną) oraz poznawczym (kontrola poznawcza i refleksja dotycząca poziomu emocjonalnego i behawioralnego).

Intensywność i częstotliwość doświadczania emocji zależy zwłaszcza od tej cechy temperamentu, którą jest reaktywność emocjonalna. U osób o wysokiej reaktywności emocjonalnej reakcje emocjonalne pojawiają się szybciej, w odpowiedzi na nawet niewielkie bodźce emocjogenne, są częstsze i intensywniejsze niż u osób o niskiej reaktywności emocjonalnej. Stanowi to pozytywny aspekt tej cechy temperamentu, jako że inteligencja emocjonalna może rozwijać się wyłącznie na bazie materiału, jakim są emocje. Negatywną stroną wykazywania się przez jednostkę wysoką reaktywnością jest skłonność do częstszego przeżywania emocji negatywnych (np. lęku) oraz ryzyko przestymulowania.

Inteligencja emocjonalna, stanowiąc składnik inteligencji skrystalizowanej, rozwija się dzięki angażowaniu potencjału inteligencji płynnej w takie działania, które są źródłem emocji. Do działań tych należą kontakty interpersonalne (stanowiące istotę szeroko rozumianej aktywności społecznej) oraz aktywność zadaniowa. Oba rodzaje aktywności należą do silnie stymulujących oraz emocjogennych. Tym więc, co decyduje o częstości i intensywności aktywności społecznej i/lub zadaniowej podejmowanej przez jednostkę, mogą być jej możliwości przetwarzania stymulacji oraz zapotrzebowanie na nią.

$\mathrm{Na}$ poziomie kognitywnym niebagatelną rolę $\mathrm{w}$ rozwoju inteligencji emocjonalnej odgrywa kontrola poznawcza. Jej efektywność warunkowana jest przez optymalny (nie za duży i nie za mały) poziom pobudzenia. Optymalny poziom pobudzenia oznacza utrzymywanie pobudzenia na stosunkowo wysokim poziomie (co podtrzymuje działanie i towarzyszące emocje), ale zarazem niedopuszczanie do stanu ponadoptymalnego, który osłabiałby lub uniemożliwiał kontrolę.

Tym, co odgrywa istotną rolę przy regulacji poziomu pobudzenia $\mathrm{u}$ jednostki, jest rodzaj struktury temperamentu - zharmonizowany lub niezharmonizowany. Struktura ta zależna jest od stopnia adekwatności zapotrzebowania na stymulację w stosunku do posiadanych przez jednostkę możliwości przetwarzania tej stymulacji. W przypadku występowania równowagi pomiędzy poziomem zapotrzebowania na stymulację a możliwościami przetwarzania stymulacji (mała potrzeba stymulacji i małe 
możliwości przetwarzania stymulacji lub duża potrzeba stymulacji i duże możliwości przetwarzania stymulacji) mamy do czynienia ze zharmonizowaną strukturą temperamentu. Natomiast w przypadku występowania rozbieżności między potrzebami a możliwościami w zakresie przetwarzania stymulacji (współwystępowanie dużego zapotrzebowania na stymulację i małych możliwości przetwarzania stymulacji lub małego zapotrzebowania na stymulację i dużych możliwości przetwarzania stymulacji) mamy do czynienia z niezharmonizowaną strukturą temperamentu.

Ta cecha temperamentu, którą w Regulacyjnej Teorii Temperamentu określa się mianem perseweratywności, umożliwia refleksję poznawczą nad doświadczanymi emocjami, zachowaniem (będącym ich źródłem lub wynikiem), jak i nad ich wzajemną interakcją. Przykładowo, jeden z przejawów inteligencji emocjonalnej, jakim jest wiedza emocjonalna, powstaje w toku aktywności poznawczej, zwłaszcza dzięki treningowi w analizowaniu reakcji emocjonalnych - własnych i cudzych.

Jak widać, różne parametry temperamentu mogą odgrywać rolę w kształtowaniu się i rozwoju różnych aspektów inteligencji emocjonalnej. Można sądzić, że duże możliwości w zakresie przetwarzania stymulacji będą sprzyjały rozwojowi działaniowej inteligencji emocjonalnej, zaś małe możliwości w zakresie przetwarzania stymulacji - poznawczej inteligencji emocjonalnej.

Powyższe założenia były podstawą pytań badawczych i hipotez, które weryfikowałam w badaniach własnych. Głównym pytaniem podjętej pracy było: czy poszczególne parametry temperamentu tworzą kombinacje czynników odpowiedzialnych za różne rodzaje zdolności wchodzących w skład inteligencji emocjonalnej oraz jak kształtuje się profil inteligencji emocjonalnej u osób o różnych poziomach możliwości przetwarzania stymulacji? Kolejne pytania wynikające $\mathrm{z}$ wcześniejszego to: czy istnieje zróżnicowanie w zakresie inteligencji emocjonalnej u osób o różnych możliwościach przetwarzania stymulacji? Czy fakt posiadania zharmonizowanej lub niezharmonizowanej struktury temperamentu będzie miał przełożenie na poziom inteligencji emocjonalnej jednostki?

W odpowiedzi na powyższe pytania postawiono następującą hipotezę ogólną: 
Związki inteligencji emocjonalnej z temperamentem mogą się kształtować różnie w zależności od typu czy komponentu inteligencji emocjonalnej. Poznawcze komponenty inteligencji emocjonalnej wiążą się dodatnio z cechami temperamentu warunkującymi małe możliwości przetwarzania stymulacji. Działaniowe komponenty inteligencji emocjonalnej wiążą się dodatnio z cechami temperamentu warunkującymi duże możliwości przetwarzania stymulacji.

Hipotezę ogólną uszczegółowiono, formułując kolejne hipotezy w następujący sposób:

- Istnieje dodatni związek pomiędzy cechami temperamentu znamionującymi małe możliwości przetwarzania stymulacji a poznawczą inteligencją emocjonalną.

- Istnieje dodatni związek pomiędzy cechami temperamentu znamionującymi duże możliwości przetwarzania stymulacji a działaniową inteligencją emocjonalną.

- Istnieje dodatni związek pomiędzy wrażliwością sensoryczną a inteligencją emocjonalną. Wrażliwość sensoryczna jest ważnym predyktorem zarówno poznawczej jak i działaniowej inteligencji emocjonalnej.

- Profil osób o temperamencie warunkującym małe możliwości przetwarzania stymulacji charakteryzuje wyższy poziom inteligencji emocjonalnej w zakresie zdolności do rozumienia emocji i niższy w zakresie kontroli emocjonalnej (wchodzących w skład inteligencji emocjonalnej strategicznej) oraz wyższy poziom inteligencji emocjonalnej w zakresie empatii oraz niższy w zakresie zdolności do wykorzystywania własnych emocji w działaniu (wchodzących w skład inteligencji emocjonalnej doświadczeniowej).

- Profil osób o temperamencie warunkującym duże możliwości przetwarzania stymulacji charakteryzuje wyższy poziom inteligencji emocjonalnej w zakresie zdolności kontroli emocji i niższy w zakresie zdolności rozumienia emocji (wchodzących w skład inteligencji emocjonalnej strategicznej) oraz wyższy w zakresie zdolności do wykorzystywania własnych emocji w działaniu i niższy 
w zakresie empatii (wchodzących w skład inteligencji emocjonalnej doświadczeniowej).

- Rodzaj struktury temperamentu - zharmonizowany lub niezharmonizowany - ma związek z ogólnym poziomem inteligencji emocjonalnej. Osoby o zharmonizowanej strukturze temperamentu mają wyższy poziom ogólnej inteligencji emocjonalnej niż osoby o niezharmonizowanej strukturze temperamentu.

Kierunek postawionych hipotez badawczych wynikał z przypuszczenia, że osoby o małych i dużych możliwościach przetwarzania stymulacji mogą różnić się między sobą profilem inteligencji emocjonalnej (zarówno jedne, jak i drugie mogą wykazywać mocne i słabe strony w obrębie inteligencji emocjonalnej). $Z$ kolei na podstawie danych $\mathrm{z}$ piśmiennictwa psychologicznego można było domniemywać, że efektywne funkcjonowanie jednostki w różnych sferach wymaga posiadania przez nią zharmonizowanej struktury temperamentu.

W dalszej części pracy prezentuję obszernie wyniki przeprowadzonych przeze mnie badań mających na celu weryfikację powyższych hipotez. Pomiaru temperamentu dokonano za pomocą kwestionariusza operacjonalizującego RTT - FCZ-KT, autorstwa Zawadzkiego i Strelaua (por. Zawadzki, Strelau, 1997). Kwestionariusz ten ma charakter samoopisowy; zawiera 120 stwierdzeń (po dwadzieścia dla każdej z sześciu skal: żwawości, perseweratywności, wrażliwości sensorycznej, reaktywności emocjonalnej, wytrzymałości i aktywności). Stwierdzenia tworzące poszczególne skale występują w porządku losowym. Każda pozycja kwestionariusza wymaga od badanego ustosunkowania się w postaci udzielenia odpowiedzi twierdzącej („tak”) lub przeczącej („nie”). Przy pomocy tego narzędzia można wyróżnić cztery typy struktury temperamentu: strukturę zharmonizowaną wskazującą na duże możliwości przetwarzania stymulacji, strukturę zharmonizowaną wskazującą na małe możliwości przetwarzania stymulacji, strukturę niezharmonizowaną wskazującą na duże możliwości przetwarzania stymulacji oraz strukturę niezharmonizowaną wskazującą na małe możliwości przetwarzania stymulacji.

Rzetelność pomiaru oszacowana współczynnikiem alfa Cronbacha jest satysfakcjonująca dla wszystkich skal tego kwestionariusza (między 0,73 a 0,85). Cechy mierzone FCZ-KT spełniają także takie kryterium wymagane 
od cech temperamentu jak znaczne ich intraindywidualne zróżnicowanie oraz kryterium stałości czasowej. Właściwości psychometryczne FCZ-KT w tym kontekście są zadowalające i nie odbiegają od standardów stawianych tego typu narzędziom diagnostycznym (Zawadzki, Strelau, 1997).

Pomiaru inteligencji emocjonalnej w badaniach własnych dokonano za pomocą PKIE, o którym była mowa już wcześniej. Analizy dotyczące związków inteligencji emocjonalnej z temperamentem były przeprowadzone na tej samej grupie osób, co w przypadku analiz dotyczących różnic międzypłciowych w inteligencji emocjonalnej (por. rozdział 4.2.).

Najpierw zanalizowano profil temperamentu kobiet i mężczyzn. Dotychczasowe dane z literatury na temat różnic międzypłciowych, jeśli chodzi o cechy temperamentu w ujęciu RTT, mówią o większej reaktywności emocjonalnej, perseweratywności i wrażliwości sensorycznej u kobiet oraz o większej aktywności, żwawości i wytrzymałości mężczyzn. W znacznej mierze podobne różnice wystąpiły w zbadanej przeze mnie grupie. Wyniki kobiet i mężczyzn okazały się istotnie różne, co zostało sprawdzone testem U Manna-Whitneya (załącznik A, tabela A1). Dotyczy to istotnie statystycznie większej perseweratywności, reaktywności emocjonalnej i wrażliwości sensorycznej kobiet oraz istotnie statystycznie większej wytrzymałości mężczyzn. Nie stwierdzono natomiast oczekiwanej różnicy pomiędzy kobietami i mężczyznami w zakresie żwawości i aktywności.

Zgodnie z literaturą na ten temat (por. Zawadzki, Strelau, 1997) zależności pomiędzy cechami temperamentu układają się w ten sposób, że dodatnio korelują: żwawość z wrażliwością sensoryczną, aktywnością i wytrzymałością; aktywność z wytrzymałością oraz perseweratywność z reaktywnością emocjonalną; natomiast ujemnie: żwawość z perseweratywnością i reaktywnością emocjonalną; aktywność z reaktywnością emocjonalną oraz wytrzymałość z reaktywnością emocjonalną i perseweratywnością. Taki sam kierunek zależności pomiędzy składowymi temperamentu ujawnił się w wynikach badanych osób. Przy tym siła związku pomiędzy niektórymi parametrami w mojej grupie badawczej była nieco niższa niż w grupie normalizacyjnej.

Na podstawie wyników pomiaru temperamentu wyłoniono osoby o różnych profilach temperamentu, stosując kryterium 0,5 odchylenia od średniej, biorąc pod uwagę dwa parametry temperamentu: reaktywność emocjonalną i aktywność. Wyłonione profile temperamentu to: typ 
zharmonizowany o dużych możliwościach przetwarzania stymulacji, typ zharmonizowany o małych możliwościach przetwarzania stymulacji, typ niezharmonizowany o dużych możliwościach przetwarzania stymulacji, typ niezharmonizowany o małych możliwościach przetwarzania stymulacji oraz typ niezróżnicowany.

Rozkład liczebności występowania poszczególnych profilów zarówno w grupie kobiet, jak i w grupie mężczyzn pokazuje, że najczęściej występującym profilem temperamentu w mojej grupie badanych jest zharmonizowany profil temperamentu o dużych możliwościach przetwarzania stymulacji, następnie zharmonizowany profil o małych możliwościach przetwarzania stymulacji, w dalszej kolejności jest to niezharmonizowany profil o małych możliwościach przetwarzania stymulacji, zaś najrzadziej występującym okazał się niezharmonizowany profil temperamentu o dużych możliwościach przetwarzania stymulacji. Czytelnika zainteresowanego bardziej szczegółowymi danymi liczbowymi na ten temat odsyłam do załączników (załącznik A, tabela A2, rysunki A1 i A2).

\subsubsection{Korelacje pomiędzy inteligencją emocjonalną a cechami} temperamentu. W celu sprawdzenia, jaki jest kierunek i siła związków pomiędzy skalami inteligencji emocjonalnej a parametrami temperamentu, ze względu na fakt istniejących odchyleń od rozkładu normalnego w wynikach, postanowiono zastosować współczynnik korelacji $\tau$ Kendalla. Tabela 7 przedstawia korelacje pomiędzy wskaźnikami inteligencji emocjonalnej a wskaźnikami cech temperamentu dla kobiet, zaś tabela 8 - te same korelacje dla mężczyzn (dane dotyczące ogółu badanych znajdują się w załączniku $\mathrm{B}, \mathrm{w}$ tabeli B1). 
Tabela 7

Współczynniki korelacji pomiędzy wskaźnikami inteligencji emocjonalnej a wskaźnikami cech temperamentu dla próby kobiet $(\mathrm{N}=415)$

\begin{tabular}{ccccccc}
\hline $\begin{array}{c}\text { Zmien- } \\
\text { na }\end{array}$ & $\dot{Z} \mathbf{W}$ & PE & WS & RE & AK & WT \\
\hline AKC & $0,16^{* * *}$ & $-0,08^{*}$ & $0,10^{* *}$ & $-0,24^{* * *}$ & $0,24^{* * *}$ & $0,11^{* *}$ \\
EMP & $0,10^{* *}$ & $-0,02$ & $0,13^{* * *}$ & $-0,06$ & 0,03 & 0,06 \\
ROZ & $0,15^{* * *}$ & $-0,20^{* * *}$ & $0,09^{* *}$ & $-0,31^{* * *}$ & 0,01 & $0,19^{* * *}$ \\
KON & $0,18^{* * *}$ & $-0,20^{* * *}$ & $0,10^{* *}$ & $-0,30^{* * *}$ & 0,04 & $0,16^{* * *}$ \\
WO & $0,25^{* * *}$ & $-0,16^{* * *}$ & $0,18^{* * *}$ & $-0,31^{* * *}$ & $0,14^{* * *}$ & $0,20^{* * *}$ \\
\hline
\end{tabular}

Adnotacja. Skale FCZ-KT: ŻW - żwawość; PE - perseweratywność; WS - wrażliwość sensoryczna; RE - reaktywność emocjonalna; AK - aktywność; WT - wytrzymałość. Skale PKIE: AKC - akceptowanie; EMP - empatia; KON - kontrola; ROZ - rozumienie; WO - wynik ogólny w PKIE.

${ }^{\star} p<0,05 ;{ }^{* *} p<0,01 ;{ }^{* *} p<0,001$.

\section{Tabela 8}

Współczynniki korelacji pomiędzy wskaźnikami inteligencji emocjonalnej a wskaźnikami cech temperamentu dla próby mężczyzn $(\mathrm{N}=301)$

\begin{tabular}{ccccccc}
\hline $\begin{array}{c}\text { Zmien- } \\
\text { na }\end{array}$ & $\mathbf{Z} \mathbf{W}$ & PE & WS & RE & AK & WT \\
\hline AKC & $0,21^{* * *}$ & $-0,03$ & $0,18^{* * *}$ & $-0,31^{* * *}$ & $0,30^{* * *}$ & $0,12^{* *}$ \\
EMP & $0,14^{* * *}$ & $-0,01$ & $0,23^{* * *}$ & $-0,09^{*}$ & $0,11^{* *}$ & 0,06 \\
ROZ & $0,25^{* * *}$ & $-0,33^{* * *}$ & $0,10^{*}$ & $-0,38^{* * *}$ & 0,04 & $0,27^{* * *}$ \\
KON & $0,27^{* * *}$ & $-0,23^{* * *}$ & $0,21^{* * *}$ & $-0,36^{* * *}$ & $0,11^{* *}$ & $0,21^{* * *}$ \\
WO & $0,32^{* * *}$ & $-0,16^{* * *}$ & $0,27^{* * *}$ & $-0,39^{* * *}$ & $0,20^{* * *}$ & $0,22^{* * *}$ \\
\hline
\end{tabular}

Adnotacja. Skale FCZ-KT: ŻW - żwawość; PE - perseweratywność; WS - wrażliwość sensoryczna; RE - reaktywność emocjonalna; AK - aktywność; WT - wytrzymałość. Skale PKIE: AKC - akceptowanie; EMP - empatia; KON - kontrola; ROZ - rozumienie; WO - wynik ogólny w PKIE.

${ }^{\star} p<0,05 ;{ }^{\star *} p<0,01 ;{ }^{\star * \star} p<0,001$. 
Wyniki ogólne uzyskane w PKIE korelowały w obu grupach istotnie, choć słabo ze wszystkimi skalami temperamentu:

- akceptacja emocji korelowała dodatnio ze żwawością, wrażliwością sensoryczną, aktywnością i wytrzymałością, zaś ujemnie - z reaktywnością emocjonalną;

- empatia wykazała słaby istotny związek dodatni z takimi parametrami temperamentu jak żwawość, wrażliwość sensoryczna i aktywność;

- rozumienie emocji okazało się być związane dodatnio (choć również słabo) ze żwawością, wrażliwością sensoryczną i wytrzymałością, zaś ujemnie - w sposób umiarkowany z perseweratywnością i reaktywnością emocjonalną;

- kontrola emocjonalna ujawniła dodatni związek ze żwawością, wrażliwością sensoryczną, aktywnością i wytrzymałością, zaś ujemny z perseweratywnością i reaktywnością emocjonalną.

Powyższe wyniki zdają się sugerować, że na poziom inteligencji emocjonalnej, niezależnie od branego pod uwagę jej typu, korzystny wpływ mają duże możliwości przetwarzania stymulacji. Kolejnym wnioskiem jest to, że wrażliwość sensoryczna jest predyktorem wysokich wyników w inteligencji emocjonalnej, na co mogą wskazywać istotne (choć słabe) korelacje pomiędzy tą cechą temperamentu a zdolnościami emocjonalnymi występującymi w PKIE.

W wynikach uwzględniających podział na kobiety i mężczyzn stwierdzono pewne różnice międzypłciowe w uzyskanych wynikach. U kobiet wystąpił słaby ujemny związek między akceptacją emocji a perseweratywnością. Zależności takiej nie zaobserwowano w grupie mężczyzn. Z kolei u mężczyzn wystąpił słaby dodatni związek pomiędzy empatią i kontrolą emocji a taką cechą temperamentu jak aktywność, a także słaby ujemny związek pomiędzy empatią a reaktywnością emocjonalną. Związki te nie ujawniły się w grupie kobiet.

W celu określenia zależności pomiędzy zmiennymi wchodzącymi w zakres temperamentu a zmiennymi składającymi się na inteligencję emocjonalną, zastosowano analizę kanoniczną. Pozwala ona określić siłę związku między dwoma zestawami zmiennych, dlatego lepiej nadaje się do badania zależności między temperamentem a inteligencją emocjonalną 
niż współczynniki korelacji między poszczególnymi zmiennymi. Oprócz tego, że pojedyncze zmienne nie są izolowane ze swojego kontekstu, analiza wielozmiennowa ma tę zaletę, że jest mniej podatna na błąd I rodzaju (przy wielokrotnym stosowaniu tych samych danych do weryfikowania różnych hipotez wzrasta prawdopodobieństwo uzyskania istotnych wyników, mimo że w rzeczywistości nie ma podstaw do odrzucenia hipotezy zerowej).

Pierwszym problemem było określenie zestawów zmiennych. Temperament w ujęciu RTT określa sześć cech. Struktura temperamentu ma dobre uzasadnienie teoretyczne, jednak niektóre wymiary temperamentu są silnie powiązane z innymi. Jednym z założeń analizy kanonicznej jest to, że zmienne w zestawach nie są silnie skorelowane (nie występuje współliniowość). W przeciwnym przypadku interpretacja w oparciu o pojedyncze zmienne jest mniej rzetelna (Hair, Anderson, Black, Babin, 2009). W odniesieniu do RTT nie jest to jednak ważka przeszkoda, ponieważ zmienne i tak mogą być traktowane łącznie jako odpowiadające za duże lub małe możliwości przetwarzania stymulacji. Zatem w analizach można było uwzględnić wszystkie parametry temperamentu z RTT.

Analiza kanoniczna, uwzględniająca inteligencję emocjonalną rozumianą jako cztery skale PKIE, ujawniła silne zależności pomiędzy temperamentem a inteligencją emocjonalną. Podobne wyniki ujawniły się po odrzuceniu skali rozumienia skorelowanej silnie ze skalą kontroli, umiarkowanie - ze skalą akceptowania i słabo - ze skalą empatii. W aneksie znajdują się wyniki analizy kanonicznej dla sześciu cech temperamentu i inteligencji emocjonalnej traktowanej jako układ wyników wyżej wymienionych trzech zdolności emocjonalnych (załącznik C, tabele C1 i C2).

Tabele 9 i 10 przedstawiają korelacje kanoniczne pomiędzy temperamentem a inteligencją emocjonalną u kobiet i u mężczyzn.

Tabela 9

Korelacje kanoniczne między temperamentem a inteligencja emocjonalna $w$ grupie kobiet $(\mathrm{N}=415)$

\begin{tabular}{ccccc}
\hline $\mathbf{N r}$ & $\boldsymbol{R}$ & $\boldsymbol{R c}^{\mathbf{2}}$ & $\boldsymbol{R} \boldsymbol{I}_{\boldsymbol{I E}}$ & $\boldsymbol{R I}_{\boldsymbol{T}}$ \\
\hline 1 & $0,55^{* * *}$ & 0,30 & $14,44 \%$ & $9,78 \%$ \\
2 & $0,36^{* * *}$ & 0,13 & $2,60 \%$ & $2,11 \%$ \\
& & & & Ciąg dalszy tabeli na następnej stronie
\end{tabular}




\begin{tabular}{ccccc}
\hline $\mathbf{N r}$ & $\boldsymbol{R c}$ & $\boldsymbol{R c}^{\mathbf{2}}$ & $\boldsymbol{R I}_{\boldsymbol{I E}}$ & $\boldsymbol{R I}_{\boldsymbol{T}}$ \\
\hline 3 & $0,22^{* *}$ & 0,05 & $1,08 \%$ & $0,70 \%$ \\
4 & 0,09 & 0,01 & $0,07 \%$ & $0,07 \%$ \\
\hline
\end{tabular}

Adnotacja. Rc - Współczynnik korelacji kanonicznej; $\mathrm{RI}_{\mathrm{IE}}$ - wskaźnik redundancji dla inteligencji emocjonalnej; $\mathrm{RI}_{\mathrm{T}}$ - wskaźnik redundancji dla temperamentu.

${ }^{* *} p<0,01 ;{ }^{* * *} p<0,001$.

Tabela 10

Korelacje kanoniczne między temperamentem a inteligencja emocjonalnq $w$ grupie mężczyzn $(\mathrm{N}=301)$

\begin{tabular}{ccccc}
\hline $\mathbf{N r}$ & $\boldsymbol{R} \boldsymbol{C}$ & $\boldsymbol{R c}^{\mathbf{2}}$ & $\boldsymbol{R} \boldsymbol{I}_{\mathbf{I E}}$ & $\boldsymbol{R I}_{\boldsymbol{T}}$ \\
\hline 1 & $0,66^{* * *}$ & 0,44 & $21,64 \%$ & $17,09 \%$ \\
2 & $0,49^{* * *}$ & 0,24 & $5,27 \%$ & $3,86 \%$ \\
3 & $0,29^{* *}$ & 0,08 & $1,58 \%$ & $1,20 \%$ \\
4 & 0,09 & 0,01 & $0,08 \%$ & $0,09 \%$ \\
\hline
\end{tabular}

Adnotacja. Rc - Współczynnik korelacji kanonicznej; $\mathrm{RI}_{\mathrm{IE}}$ - wskaźnik redundancji dla inteligencji emocjonalnej; $\mathrm{RI}_{\mathrm{T}}$ - wskaźnik redundancji dla temperamentu.

${ }^{\star *} p<0,01 ;{ }^{* * *} p<0,001$.

Z czterech korelacji kanonicznych trzy okazały się istotne zarówno w grupie kobiet, jak i w grupie mężczyzn. Pierwszą funkcję kanoniczną można określić jako silną w całej próbie $(R c[714]=0,61)$, w grupie mężczyzn $(R c[299]=0,66)$ i w grupie kobiet $(R c[413]=0,55)$. Pierwsza para funkcji kanonicznych odpowiada za 37\% wariancji w całej próbie, analogicznie - 30\% w grupie kobiet i $44 \% \mathrm{w}$ grupie mężczyzn. Za pomocą pierwszej zmiennej kanonicznej będącej funkcją zmiennych temperamentalnych można wyjaśnić prawie $17 \%$ wariancji zmiennych wchodzących w skład inteligencji emocjonalnej w całej próbie (14,4\% w grupie kobiet i 21,6\% w grupie mężczyzn). Za pomocą wariancji pierwszej zmiennej kanonicznej pochodzącej ze skal PKIE można wyjaśnić 9,8\% wariancji zmiennych 
temperamentalnych z FCZ-KT w grupie kobiet i $17,1 \%$ wariancji zmiennych w grupie mężczyzn.

Druga korelacja kanoniczna jest umiarkowana - i w grupie kobiet $(R c[413]=0,36)$, i w grupie mężczyzn $(R c[299]=0,49)$. Indeks redundancji dla inteligencji emocjonalnej wynosi dla kobiet 2,6\%, dla mężczyzn 5,3\%, a indeks redundancji dla temperamentu $2,1 \%$ w grupie kobiet i 3,9\% w grupie mężczyzn.

Trzecia spośród istotnych korelacji jest słaba $(R c[714]=0,27 ; R c[413]$ = 0,22; $R c[299]$ = 0,29); zmienne kanoniczne tłumaczą znikomą część wariancji przeciwnych zmiennych wyjściowych (od 0,7\% do 1,6\%). Czwarta korelacja kanoniczna jest mniejsza od $0,1 \mathrm{w}$ obu grupach oraz nieistotna nawet w 716-osobowej próbie $(R c[714]=0,09)$.

Aby zinterpretować, na czym polegają istotne zależności, zbadano strukturę każdej pary zmiennych kanonicznych. Więcej szczegółów opisujących zastosowaną metodę oraz uzyskane dane liczbowe jest zamieszczonych w załączniku C (tabele C3-C8).

Podsumowując wyniki analizy kanonicznej: inteligencja emocjonalna jest powiązana $\mathrm{z}$ temperamentem na trzy sposoby:

- najsilniejsza stwierdzona ujemna zależność istnieje pomiędzy reaktywnością emocjonalną a inteligencją strategiczną;

- umiarkowanie dodatnio związana jest aktywność z akceptacją emocji;

- najsłabsza dodatnia zależność występuje pomiędzy wrażliwością sensoryczną i empatią.

Te trzy zależności wyjaśniają 22,8\% wariancji zmiennych inteligencji emocjonalnej z PKIE (indeks redundancji w całej próbie) i 17,5\% wariancji zmiennych temperamentu z RTT. Wyniki sugerują, że korzystniejsza dla inteligencji emocjonalnej strategicznej jest niska reaktywność emocjonalna, zaś dla inteligencji emocjonalnej doświadczeniowej - wysoka aktywność (ten związek akurat jest zgodny z jedną z postawionych hipotez o wyższym poziomie zdolności do wykorzystywania własnych emocji w działaniu u osób o dużych możliwościach przetwarzania stymulacji). Osoby „niskoreaktywne”, a zarazem bardzo aktywne, cechują się dużymi możliwościami 
przetwarzania stymulacji i zharmonizowaną strukturą temperamentu. $\mathrm{Na}$ podstawie otrzymanych wyników można wnioskować, że właśnie osoby o takiej charakterystyce, w porównaniu $\mathrm{z}$ innymi, będą wykazywały się wyższą inteligencją emocjonalną.

\subsubsection{Możliwości przetwarzania stymulacji a inteligencja emo-}

cjonalna. Temperament rozumiany w ujęciu Regulacyjnej Teorii Temperamentu (RTT) warunkuje w dużym stopniu tendencję jednostki do podejmowania aktywności społecznej i zadaniowej. Te rodzaje aktywności są silnie stymulujące, stąd zarówno częstość, jak i intensywność angażowania się w nie może zależeć od temperamentalnie uwarunkowanych możliwości przetwarzania stymulacji i temperamentalnie wyznaczanego zapotrzebowania na stymulację.

Spośród cech temperamentu wymienianych w RTT dodatnio korelują: żwawość z wrażliwością sensoryczną, aktywnością i wytrzymałością; aktywność z wytrzymałością oraz perseweratywność z reaktywnością emocjonalną. Ujemnie korelują natomiast: żwawość z perseweratywnością i reaktywnością emocjonalną; aktywność z reaktywnością emocjonalną oraz wytrzymałość z reaktywnością emocjonalną i perseweratywnością (Zawadzki, Strelau, 1997).

Sugeruje to istnienie dwóch podstawowych układów cech temperamentu: warunkującego małe możliwości przetwarzania stymulacji (wysoka reaktywność, perseweratywność; niska żwawość, aktywność i wytrzymałość) oraz warunkującego duże możliwości przetwarzania stymulacji (wysoka aktywność, wytrzymałość, żwawość; niska reaktywność i perseweratywność). Są podstawy ku temu, by spodziewać się, że rodzaj temperamentu posiadanego przez daną osobę będzie wpływał w dużej mierze na poziom zdolności składających się na inteligencję emocjonalną.

Można sądzić, że pewne cechy temperamentu, z jednej strony, mogą ułatwiać nabywanie i rozwój jednych zdolności wchodzących w skład inteligencji emocjonalnej, a z drugiej utrudniać nabywanie i rozwój innych. Na przykład, zbyt silna kontrola własnych emocji i zachowań może obniżać tendencję jednostki do emocjonalnej synchronizacji z innymi. Innymi słowy, jeśli kontrola emocjonalna - z reguły „łatwiej przychodząca” osobom nisko reaktywnym - jest zbyt duża, to odbywa się kosztem jednej ze zdolności z obszaru inteligencji emocjonalnej, takiej jak empatia. Innym 
przykładem może być „podwyższona wrażliwość na bodźce” występująca u osób wysoko reaktywnych (Strelau, 1985), co z kolei będzie miało przełożenie na większą ich zdolność w zakresie percepcji i rozpoznawania emocji. Badania Ogińskiej-Bulik (1992) wykazały, że osoby o małym zapotrzebowaniu na stymulację, z silną tendencją do unikania kar, bardziej koncentrują się poznawczo na bodźcach społecznych, co może zwiększać ich zdolności emocjonalne $\mathrm{w}$ takim obszarze jak percepcja (czy rozumienie) emocji innych osób. Interpretuje się ich większą koncentrację na bodźcach społecznych jako sposób redukowania stymulacji powiązanej z silnym lękiem przed niepowodzeniem, porażką czy karą ze strony otoczenia.

Zatem w tym przypadku to nie duże zapotrzebowanie na stymulację, ale wysoka reaktywność będzie czynnikiem sprzyjającym poznawczej „obróbce" emocji, których źródłem są sytuacje społeczne. Jednocześnie osoby o małym zapotrzebowaniu na stymulację, jak wynika $\mathrm{z}$ badań, minimalizują wielkość stymulacji społecznej w swoim życiu, także poprzez unikanie zawodów związanych ze społecznym zagrożeniem, czy społeczną stymulacją (Oleszkiewicz-Zsurzs, 1986).

Także inne badania potwierdziły, że, mając niski próg wrażliwości, osoby wysoko reaktywne łatwo ulegają pobudzeniu emocjonalnemu, są też bardziej wrażliwe na emocje innych ludzi, a więc bardziej empatyczne (Mehrabian i in., 1988), co potwierdziły także badania Kliś i Kossewskiej (1994), które wykazały dodatni związek reaktywności oraz ujemny siły procesu hamowania z empatią. Większą empatię osób wysoko reaktywnych autorki tłumaczą ich większą wrażliwością i silniejszą potrzebą afiliacji uwarunkowaną poszukiwaniem bezpieczeństwa.

Niejednoznaczny i złożony obraz przedstawiają badania Golińskiej (1993) nad tym, jak temperament warunkuje percepcję społeczną. Ujawniły one krzywoliniowy związek pomiędzy percepcją społeczną a kompetencjami społecznymi (zakładam, że kompetencje społeczne są ściśle związane $\mathrm{z}$ inteligencją emocjonalną, więc pośrednio ich poziom może świadczyć o bazowym poziomie inteligencji emocjonalnej). Wynika z nich, że najtrafniejszą percepcją innych ludzi dysponują osoby przeciętnie reaktywne. Osoby wysoko reaktywne mają obniżoną trafność percepcji na skutek charakterystycznej dla nich ostrożności, zaś osoby nisko reaktywne - wskutek właściwej im swoistej beztroski. Takie wyniki utwierdzają w przekonaniu, że zarówno wysoka, jak i niska reaktywność, rozpatrywane jako czynniki 
warunkujące poziom inteligencji emocjonalnej, czy efektywność relacji społecznych, mają swoje pozytywne i negatywne aspekty.

Tym, co sprzyja rozwojowi inteligencji emocjonalnej, a - co za tym idzie - także kompetencji społecznych u wysoko reaktywnych, są wrażliwość emocjonalna (reaktywność emocjonalna) i poznawcza koncentracja na bodźcach społecznych, zaś u tych samych osób niesprzyjające będą w tym względzie lękowy charakter tej koncentracji oraz tendencja do unikania stymulacji. Z kolei czynnikiem sprzyjającym rozwojowi inteligencji emocjonalnej u nisko reaktywnych będzie poszukiwanie stymulacji poprzez kontakty z innymi i, w związku z tym, angażowanie się w trudne (ale jakże rozwijające) sytuacje społeczne, przez co, w warunkach naturalnych, trenują oni różne emocjonalno-społeczne zdolności i umiejętności; czynnikiem niekorzystnym dla nich będzie zaś ich mniejsze zainteresowanie ludźmi jako takimi (Matczak, 2001b).

Kontakty z innymi ludźmi stanowią bardzo często źródło silnej stymulacji, stąd intensywność aktywności społecznej będzie zależna od poziomu zapotrzebowania na stymulację (możliwości przetwarzania stymulacji). Poziom dostarczanej stymulacji w kontaktach interpersonalnych oczywiście zależeć będzie również od rodzaju kontaktu społecznego - nie każdy będzie tak silnie stymulujący, jak np. sytuacja ekspozycji społecznej, co jest o tyle korzystne dla tych „chronicznie przestymulowanych”, że być może w niektórych sytuacjach interpersonalnych będą sobie radzić lepiej, a przynajmniej równie dobrze (np. w sytuacji relacji z przyjacielem czy intymnej), jak ci „wiecznie niedostymulowani”. Warunki i tempo współczesnego życia wydają się bardziej sprzyjać osobom o dużych możliwościach przetwarzania stymulacji. W kontekście poruszanego tematu można przypuszczać jednak, że osoby o małych możliwościach przetwarzania stymulacji mogą wykazywać się wyższym poziomem w zakresie niektórych zdolności emocjonalnych, a co za tym idzie - lepiej funkcjonować emocjonalnie w pewnych obszarach życia.

Wysoki poziom każdej cechy posiadanej przez jednostkę skutkuje zarazem niskim poziomem cechy dla niej przeciwstawnej (np. systematyczność vs. spontaniczność). Każda ze specyficznych cech osobowości człowieka dorosłego może w niektórych sytuacjach okazać się adaptacyjna, w innych zaś niekorzystna (Zeidner, 2008). Sprzeczności (być może pozorne) w przytoczonych wcześniej wynikach badań stały się główną podstawą 
przypuszczenia, że tym, co przede wszystkim wiąże się z temperamentem nie jest poziom inteligencji emocjonalnej, lecz jej profil.

W grupie kobiet oraz w grupie mężczyzn wyodrębniłam osoby o małych i dużych możliwościach przetwarzania stymulacji. Osoby o małych możliwościach przetwarzania stymulacji to te, których poziom reaktywności emocjonalnej jest o co najmniej pół odchylenia standardowego powyżej średniej dla odpowiedniej płci. Osoby o dużych możliwościach przetwarzania stymulacji zostały wyłonione analogicznie - miały o co najmniej pół odchylenia standardowego niższy wynik w skali reaktywności niż średnia dla płci.

Porównanie kobiet i mężczyzn o małych i dużych możliwościach przetwarzania stymulacji wykonano z użyciem testu $U$ Manna-Whitneya (tabela 11 i 12).

Tabela 11

Porównanie kobiet o dużych i małych możliwościach przetwarzania stymulacji $w$ zakresie miar inteligencji emocjonalnej $(D M=99, M M=112)$

DM MM

\begin{tabular}{ccccc} 
Zmienna & śr. ranga & śr. ranga & \multicolumn{1}{c}{$\boldsymbol{U}$} & Efekt $\boldsymbol{r}$ \\
\hline AKC & 132,24 & 82,80 & $2946,0^{* * *}$ & 0,40 \\
EMP & 110,61 & 101,93 & 5088,0 & 0,07 \\
KON & 139,19 & 76,67 & $2258,5^{* * *}$ & 0,51 \\
ROZ & 136,11 & 79,39 & $2563,5^{* * *}$ & 0,46 \\
WO & 139,48 & 76,40 & $2229,0^{* * *}$ & 0,52 \\
\hline
\end{tabular}

Adnotacja. DM - osoby o dużych możliwościach przetwarzania stymulacji; MM - osoby o małych możliwościach przetwarzania stymulacji. Skale PKIE: AKC - akceptowanie; EMP - empatia; KON - kontrola; ROZ - rozumienie; WO - wynik ogólny w PKIE. ${ }^{\star} p<0,05 ;{ }^{* *} p<0,01 ;{ }^{* *} p<0,001$. 
Tabela 12

Porównanie mężczyzn o dużych i małych możliwościach przetwarzania stymulacji w zakresie miar inteligencji emocjonalnej $(D M=79, M M=67)$

\begin{tabular}{ccccc}
\hline & DM & MM & & \\
Zmienna & śr. ranga & śr. ranga & $\boldsymbol{U}$ & Efekt $\boldsymbol{r}$ \\
\hline AKC & 92,94 & 50,57 & $1110,5^{* * *}$ & 0,50 \\
EMP & 80,55 & 65,19 & $2089,5^{*}$ & 0,18 \\
KON & 96,58 & 46,28 & $823,0^{* * *}$ & 0,59 \\
ROZ & 98,94 & 43,50 & $636,5^{* * *}$ & 0,65 \\
WO & 96,80 & 46,02 & $805,5^{* * *}$ & 0,60 \\
\hline
\end{tabular}

Adnotacja. DM - osoby o dużych możliwościach przetwarzania stymulacji; MM - osoby o małych możliwościach przetwarzania stymulacji. Skale PKIE: AKC - akceptowanie; EMP - empatia; KON - kontrola; ROZ - rozumienie; WO - wynik ogólny w PKIE. ${ }^{\star} p<0,05 ;{ }^{* *} p<0,01 ;{ }^{* *} p<0,001$.

Kiedy bliżej przyjrzano się wpływie różnic w zakresie możliwości przetwarzania stymulacji na inteligencję emocjonalną, okazało się, że zarówno w grupie kobiet, jak i mężczyzn w sposób istotny wyższą akceptacją, kontrolą i rozumieniem emocji cechowały się osoby o dużych możliwościach przetwarzania stymulacji. Jeśli chodzi o poziom zdolności emocjonalnej, jaką jest empatia, to tu również przewaga wystąpiła u mężczyzn o dużych możliwościach przetwarzania stymulacji w porównaniu z mężczyznami o małych możliwościach przetwarzania stymulacji. Natomiast u kobiet o małych i dużych możliwościach przetwarzania stymulacji nie ujawniła się różnica w poziomie empatii. Należy dodać, że wielkość różnic w grupie mężczyzn jest większa w porównaniu z grupą kobiet, stąd można przypuszczać, że u nich inteligencja emocjonalna w większym stopniu zależy od posiadanych możliwości w zakresie przetwarzania stymulacji. Podobnie zresztą wynikało $\mathrm{z}$ danych uzyskanych $\mathrm{z}$ analizy kanonicznej, gdzie pierwsze korelacje kanoniczne u mężczyzn były silniejsze niż u kobiet, o czym była mowa w poprzednim rozdziale. 


\subsubsection{Zharmonizowanie temperamentu a inteligencja emocjonal-}

na. W zależności od tego, czy zapotrzebowanie na stymulację jest adekwatne do możliwości przetwarzania stymulacji, czy też nie, mamy do czynienia ze zharmonizowaną lub niezharmonizowaną strukturą temperamentu.

Zharmonizowana struktura temperamentu oznacza albo małe możliwości przetwarzania stymulacji (wysoka reaktywność i perseweratywność, niska żwawość i wytrzymałość), którym towarzyszy małe zapotrzebowanie na stymulację, albo duże możliwości przetwarzania stymulacji (niska reaktywność i perseweratywność, wysoka wytrzymałość i żwawość), z którymi idzie w parze duże zapotrzebowanie na stymulację.

Tak więc niezharmonizowana struktura temperamentu, w przeciwieństwie do zharmonizowanej, oznacza występowanie rozbieżności pomiędzy możliwościami a preferencjami jednostki.

Brak koherencji w obrębie temperamentu oznacza nieefektywną regulację stymulacji (Eliasz, 1981). Osoby o nieefektywnej regulacji stymulacji mogą przejawiać nieadekwatne preferencje stymulacyjne i wybierać takie sytuacje, które są sprzeczne z posiadanymi możliwościami przetwarzania stymulacji. Osoby, których niezharmonizowana struktura temperamentu przejawia się $w$ tendencji do przestymulowania się będą wykazywały wysoki poziom aspiracji, preferowanie zadań zbyt trudnych w stosunku do swoich możliwości oraz tolerancję wysokiego poziomu ryzyka. Zaś osoby, których brak zharmonizowania w obrębie struktury temperamentu przejawia się w tendencji do niedostymulowania, będą wykazywały raczej niski poziom aspiracji, skłonność do wybierania zadań o zaniżonym w stosunku do swoich możliwości - poziomie trudności oraz akceptację niskiego poziomu ryzyka.

Stwierdzono, że osoby, które charakteryzuje tendencja do przestymulowywania, mogą z dużą sprawnością działać w sytuacjach niedostosowanych do ich możliwości przetwarzania stymulacji, jednak ponoszą tego wysokie koszta emocjonalne (Zawadzka, 1994, za: Strelau, 1997). Natomiast osoby o tendencji do niedostymulowywania się w sytuacjach niedostosowanych do ich możliwości charakteryzują się z reguły niską sprawnością działania. Niespójność cech temperamentu może zwiększać ryzyko występowania dysfunkcyjnych form zachowania oraz stanowić ryzyko chorób psychosomatycznych (Strelau, 1978). Na przykład, osobowość typu A, przejawiająca się w hiperaktywności, w sprzężeniu z małymi możliwościami przetwarzania 
stymulacji, stanowi ryzyko wystąpienia choroby wieńcowej lub wrzodowej (Eliasz, 1992; Eliasz, Cofta, 1992). Z kolei u osób „niedostymulowanych” istnieje zagrożenie wystąpienia choroby nowotworowej. Może u nich także wystąpić takie zaburzenie osobowości jak socjopatia (Strelau, 1978).

Zatem jeśli brak harmonijnej struktury temperamentu nie jest dla jednostki adaptacyjny, można wnioskować, że nie ma również pozytywnego wpływu na funkcjonowanie człowieka w sferze emocjonalnej, a co za tym idzie - wpływać będzie także na jego zdolności emocjonalne. Można zaryzykować wniosek, że występowanie mocnych i słabych stron w obrębie inteligencji emocjonalnej, zarówno u osób o małych, jak i o dużych możliwościach przetwarzania stymulacji będzie dotyczyło raczej jednostek o zharmonizowanej strukturze temperamentu (a już niekoniecznie tych $\mathrm{z}$ niezharmonizowaną strukturą temperamentu). W przypadku dysharmonijnego układu cech temperamentalnych osoby - zarówno o małych, jak i o dużych możliwościach przetwarzania stymulacji - nie będą wykorzystywać swoich atutów. Chroniczne przestymulowanie osób o małych możliwościach przetwarzania stymulacji uniemożliwiać im będzie skuteczną kontrolę poznawczą w sytuacjach emocjotwórczych i emocjogennych - tak więc ich potencjalna „siła” w obszarze poznawczej inteligencji emocjonalnej zostanie „osłabiona”. Z kolei niedostymulowanie osób o dużych możliwościach przetwarzania stymulacji owocować będzie deficytem aktywności oraz emocji, a w rezultacie niewykorzystaniem ich potencjalnego atutu, jakim są zdolności emocjonalne w zakresie działaniowej inteligencji emocjonalnej. Innymi słowy, osoby o niekoherentnym układzie parametrów temperamentu (niezależnie od posiadanego typu temperamentu) nie mają szans na ujawnienie i rozwinięcie swoich potencjalnych mocnych stron w zakresie inteligencji emocjonalnej.

Nawiązując do opisywanej koncepcji Matczak odnośnie do wpływu temperamentu na rozwój inteligencji emocjonalnej, można przypuszczać bardziej szczegółowo, że korzystny wpływ na nią będzie miała zharmonizowana struktura temperamentu, zaś niekorzystny - niezharmonizowana struktura temperamentu. Brak dostrojenia do siebie poszczególnych cech temperamentu może przejawiać się w nieefektywnej regulacji pobudzenia i zaowocować np. tym, że osoba o zbyt wysokim poziomie pobudzenia w stosunku do posiadanych możliwości przetwarzania stymulacji będzie miała utrudnioną kontrolę poznawczą w obrębie doświadczeń 
emocjonalnych, co nie będzie sprzyjało nabywaniu przez nią wiedzy emocjonalnej - istotnego składnika inteligencji emocjonalnej.

Dokonano podziału osób badanych ze względu na typ struktury temperamentu - zharmonizowany lub niezharmonizowany. Cechami, które wzięto tutaj pod uwagę, była kombinacja dwóch cech: reaktywności emocjonalnej i aktywności. Przyjęto założenie, że ich wartości będą różnicowały typ temperamentu, jeśli będą przyjmowały wartość niższą lub wyższą od połowy odchylenia standardowego od średniej wyników przeliczonych w całej grupie badanych. Zatem typ zharmonizowany temperamentu to wysokie wyniki w reaktywności emocjonalnej, a zarazem niskie w aktywności lub niskie wyniki w reaktywności emocjonalnej, a zarazem wysokie w aktywności. Typ niezharmonizowany temperamentu to - analogicznie - kombinacja wysokiej reaktywności emocjonalnej i wysokiej aktywności lub niskiej reaktywności i niskiej aktywności.

Przy podziale na rodzaj struktury temperamentu z pominięciem kryterium możliwości przetwarzania stymulacji, nie ujawniły się żadne istotne statystycznie różnice w ogólnym poziomie inteligencji emocjonalnej (oraz w wynikach dla poszczególnych zdolności emocjonalnych) między osobami o zharmonizowanej i niezharmonizowanej strukturze temperamentu (tabela 13). Takich samych porównań dokonano również w obrębie każdej płci, ale różnice nadal nie były istotne, stąd nie przytaczam już tutaj dalszych danych liczbowych. Uzyskane rezultaty zdają się zatem świadczyć o braku zależności pomiędzy stopniem zharmonizowania temperamentu a inteligencją emocjonalną.

\section{Tabela 13}

Porównanie badanych o zharmonizowanych $(\mathrm{N}=246)$ i niezharmonizowa$n y c h(\mathrm{~N}=111)$ strukturach temperamentu $w$ zakresie inteligencji emocjonalnej dla obu płci łącznie

\begin{tabular}{ccccc}
\hline Zmienna & $\begin{array}{c}\text { Zharmoni- } \\
\text { zowana } \\
\text { śr. ranga }\end{array}$ & $\begin{array}{c}\text { Niezharmo- } \\
\text { nizowana } \\
\text { śr. ranga }\end{array}$ & $\boldsymbol{U}$ & Efekt $\boldsymbol{r}$ \\
\hline AKC & 179,64 & 177,58 & 13495,0 & 0,01 \\
EMP & 178,86 & 179,32 & 13617,5 & 0,00 \\
& & & Ciąg dalszy tabeli na następnej stronie
\end{tabular}




\begin{tabular}{ccccc}
\hline Zmienna & $\begin{array}{c}\text { Zharmoni- } \\
\text { zowana } \\
\text { śr. ranga }\end{array}$ & $\begin{array}{c}\text { Niezharmo- } \\
\text { nizowana } \\
\text { śr. ranga }\end{array}$ & $\boldsymbol{U}$ & Efekt $\boldsymbol{r}$ \\
\hline KON & 180,60 & 175,45 & 13258,5 & 0,02 \\
ROZ & 181,17 & 174,19 & 13119,0 & 0,03 \\
WO & 181,25 & 174,02 & 13100,0 & 0,03 \\
\hline
\end{tabular}

Adnotacja. DM - osoby o dużych możliwościach przetwarzania stymulacji; MM - osoby o małych możliwościach przetwarzania stymulacji. Skale PKIE: AKC - akceptowanie; EMP - empatia; KON - kontrola; ROZ - rozumienie; WO - wynik ogólny w PKIE.

\subsubsection{Profile temperamentu a inteligencja emocjonalna u kobiet} i mężczyzn. Sprawdzono, czy profil temperamentu może warunkować inteligencję emocjonalną. Nie uwzględniono jedynie profilu niezróżnicowanego, czyli osób z wynikami w skali reaktywność emocjonalna lub aktywność nie różniącymi się od średniej (dla danej płci) więcej niż o połowę odchylenia standardowego. Wyniki testu Kruskala-Wallisa dla kobiet zestawione są w tabeli 14, a dla mężczyzn - w tabeli 15 .

Tabela 14

Porównanie typów struktury temperamentu $w$ zakresie inteligencji emocjonalnej dla kobiet

\begin{tabular}{cccccc}
\hline & $\begin{array}{c}\text { Zh DM } \\
(\mathbf{N}=\mathbf{1 2 9})\end{array}$ & $\begin{array}{c}\text { Zh MM } \\
(\mathbf{N}=\mathbf{1 1 7})\end{array}$ & $\begin{array}{c}\text { NZh DM } \\
(\mathbf{N}=\mathbf{4 9})\end{array}$ & $\begin{array}{c}\text { NZh MM } \\
(\mathbf{N}=\mathbf{6 2})\end{array}$ & $\begin{array}{c}\text { Test Kruskala- } \\
\text { Wallisa }\end{array}$ \\
$\begin{array}{c}\text { Zmien- } \\
\text { na }\end{array}$ & śr. ranga & śr. ranga & śr. ranga & śr. ranga & $\mathbf{X}^{\mathbf{2}(3)}$ \\
\hline AKC & 141,74 & 67,38 & 106,93 & 108,51 & $52,83^{* * *}$ \\
EMP & 110,12 & 96,98 & 111,91 & 110,18 & 2,31 \\
KON & 131,71 & 77,55 & 159,13 & 75,19 & $59,22^{* * *}$ \\
ROZ & 129,81 & 84,25 & 152,89 & 71,29 & $49,47^{* * *}$ \\
WO & 138,28 & 71,52 & 142,69 & 84,54 & $57,41^{* * *}$ \\
\hline
\end{tabular}

Adnotacja. Skale PKIE: AKC - akceptowanie; EMP - empatia; KON - kontrola; ROZ - rozumienie; WO - wynik ogólny w PKIE; Zh DM - struktura zharmonizowana 
w połączeniu z dużymi możliwościami przetwarzania stymulacji; Zh MM- struktura zharmonizowana w połączeniu z małymi możliwościami przetwarzania stymulacji; Nzh DM - struktura niezharmonizowana w połączeniu z dużymi możliwościami przetwarzania stymulacji; Nzh MM - struktura niezharmonizowana w połączeniu z małymi możliwościami przetwarzania stymulacji.

$* * * p<0,001$.

\section{Tabela 15}

Porównanie typów struktury temperamentu $w$ zakresie inteligencji emocjonalnej dla mężczyzn

\begin{tabular}{cccccc}
\hline & $\begin{array}{c}\text { Zh DM } \\
(\mathbf{N}=\mathbf{1 2 9})\end{array}$ & $\begin{array}{c}\text { Zh MM } \\
(\mathbf{N}=\mathbf{1 1 7})\end{array}$ & $\begin{array}{c}\text { NZh DM } \\
(\mathbf{N}=\mathbf{4 9})\end{array}$ & $\begin{array}{c}\text { NZh MM } \\
(\mathbf{N}=\mathbf{6 2})\end{array}$ & $\begin{array}{c}\text { Test Kruska- } \\
\text { la-Wallisa }\end{array}$ \\
\hline Zmienna & śr. ranga & śr. ranga & śr. ranga & śr. ranga & $\mathbf{X}^{2}(3)$ \\
AKC & 104,16 & 40,57 & 63,89 & 74,08 & $59,66^{* * *}$ \\
EMP & 88,11 & 62,09 & 60,98 & 72,48 & $12,19^{* *}$ \\
KON & 98,61 & 47,21 & 91,34 & 44,10 & $51,93^{* * *}$ \\
ROZ & 101,58 & 40,51 & 92,11 & 50,53 & $64,05^{* * *}$ \\
WO & 105,75 & 40,29 & 73,61 & 59,50 & $64,34^{* * *}$ \\
\hline
\end{tabular}

Adnotacja. Skale PKIE: AKC - akceptowanie; EMP - empatia; KON - kontrola; ROZ - rozumienie; WO - wynik ogólny w PKIE; Zh DM - struktura zharmonizowana w połączeniu z dużymi możliwościami przetwarzania stymulacji; Zh MM- struktura zharmonizowana w połączeniu z małymi możliwościami przetwarzania stymulacji; Nzh DM - struktura niezharmonizowana w połączeniu z dużymi możliwościami przetwarzania stymulacji; Nzh MM - struktura niezharmonizowana w połączeniu z małymi możliwościami przetwarzania stymulacji.

${ }^{* *} p<0,01 ;{ }^{* * *} p<0,001$.

Testy post hoc w grupach uwzględniających płeć dały zbliżone rezultaty do testów w całej próbie (wyniki dla ogółu badanych Czytelnik znajdzie w załączniku D (tabela D1). Różnica między kobietami i mężczyznami polegała na tym, że profil temperamentu nie miał żadnego znaczenia dla poziomu empatii u kobiet, natomiast u mężczyzn istotna była różnica między tymi o zharmonizowanej strukturze temperamentu i dużych możliwościach przetwarzania stymulacji a tymi o zharmonizowanej strukturze 
temperamentu i małych możliwościach przetwarzania stymulacji i efekt możliwości przetwarzania stymulacji był umiarkowany $(r=0,31)$.

Najwyższym poziomem akceptacji emocji cechowały się osoby o zharmonizowanej strukturze temperamentu i dużych możliwościach przetwarzania stymulacji, najniższym zaś - osoby o zharmonizowanej strukturze temperamentu i małych możliwościach przetwarzania stymulacji. Osoby o niezharmonizowanym typie temperamentu, niezależnie od możliwości przetwarzania stymulacji, uzyskały wyniki przeciętne w tym względzie. Można się tu zastanawiać nad ujawnioną prawidłowością, że - chociaż dla zdolności inteligencji emocjonalnej mierzonej tą skalą, czyli zdolności do akceptowania, wyrażania i wykorzystywania własnych emocji w działaniu, korzystniejsze jest zharmonizowanie struktury temperamentu w połączeniu z dużymi możliwościami przetwarzania stymulacji - w przypadku kiedy możliwości przetwarzania stymulacji są małe, korzystniejszy okazuje się brak zharmonizowania struktury temperamentu. Mogłoby to świadczyć o tym, że wykazywanie się przez osoby o małych możliwościach przetwarzania stymulacji dużą aktywnością, wbrew ich temperamentalnym uwarunkowaniom, wpływa korzystnie na poziom omawianej zdolności.

Wyniki w zakresie empatii były istotnie wyższe u osób o zharmonizowanej strukturze temperamentu i dużych możliwościach przetwarzania stymulacji w porównaniu z osobami o zharmonizowanej strukturze temperamentu i małych możliwościach przetwarzania stymulacji (na korzyść tych pierwszych). Rodzaj struktury temperamentu nie miał tutaj istotnego znaczenia. Zmienną różnicującą wyniki obu grup wydają się być posiadane możliwości w zakresie przetwarzania stymulacji. Wbrew pierwotnemu założeniu, że to osoby wysokoreaktywne są bardziej empatyczne, wyższe wyniki w zakresie zdolności do rozumienia i rozpoznawania emocji u innych osób uzyskały osoby niskoreaktywne.

Poziom kontroli i rozumienia emocji oraz ogólna inteligencja emocjonalna okazały się być wyższe również u osób o dużych możliwościach przetwarzania stymulacji, niezależnie od stopnia zharmonizowania ich temperamentu. Zatem w świetle uzyskanych wyników duże możliwości przetwarzania stymulacji wydają się być korzystne dla rozwoju zdolności do kontrolowania, także poznawczego, emocji oraz zdolności do ich rozumienia (wchodzących w zakres inteligencji emocjonalnej strategicznej). 
Analizy dotyczące interakcji struktury temperamentu oraz możliwości przetwarzania stymulacji pozwalają wnioskować o tym, że brak zharmonizowania struktury temperamentu u osób o dużych możliwościach przetwarzania stymulacji przejawia się przewagą inteligencji emocjonalnej strategicznej nad doświadczeniową, zaś u osób o małych możliwościach przetwarzania stymulacji - przewagą inteligencji emocjonalnej doświadczeniowej nad strategiczną. Zastanawiające jest to, czy taki układ cech temperamentu i zdolności inteligencji emocjonalnej jest zawsze korzystny. Na przykład, jeśli weźmiemy pod uwagę osoby o dużych możliwościach przetwarzania stymulacji, niepodejmujące aktywności adekwatnej do własnego zapotrzebowania na stymulację (co jest przejawem braku zharmonizowania struktury temperamentu), to można przypuszczać, że skoro mają one bardziej rozwiniętą inteligencję emocjonalną strategiczną, to może to skutkować u nich zbyt silną kontrolą własnych emocji, a w efekcie doprowadzić do ich tłumienia czy wypierania. Z kolei u osób o małych możliwościach przetwarzania stymulacji, które podejmują dużą aktywność (zatem nieadekwatnie do własnego zapotrzebowania na stymulację) i mają bardziej rozwiniętą inteligencję emocjonalną doświadczeniową, może wystąpić zjawisko nadmiernej ekspresji emocjonalnej i bycie „niesionym przez emocje" (z racji słabszej kontroli emocjonalnej i dużej aktywności zarazem).

Zależności pomiędzy profilem temperamentu a profilem inteligencji emocjonalnej mierzonej PKIE w grupie kobiet zostały przedstawione na rysunku 7, zaś w grupie mężczyzn - na rysunku 8. 


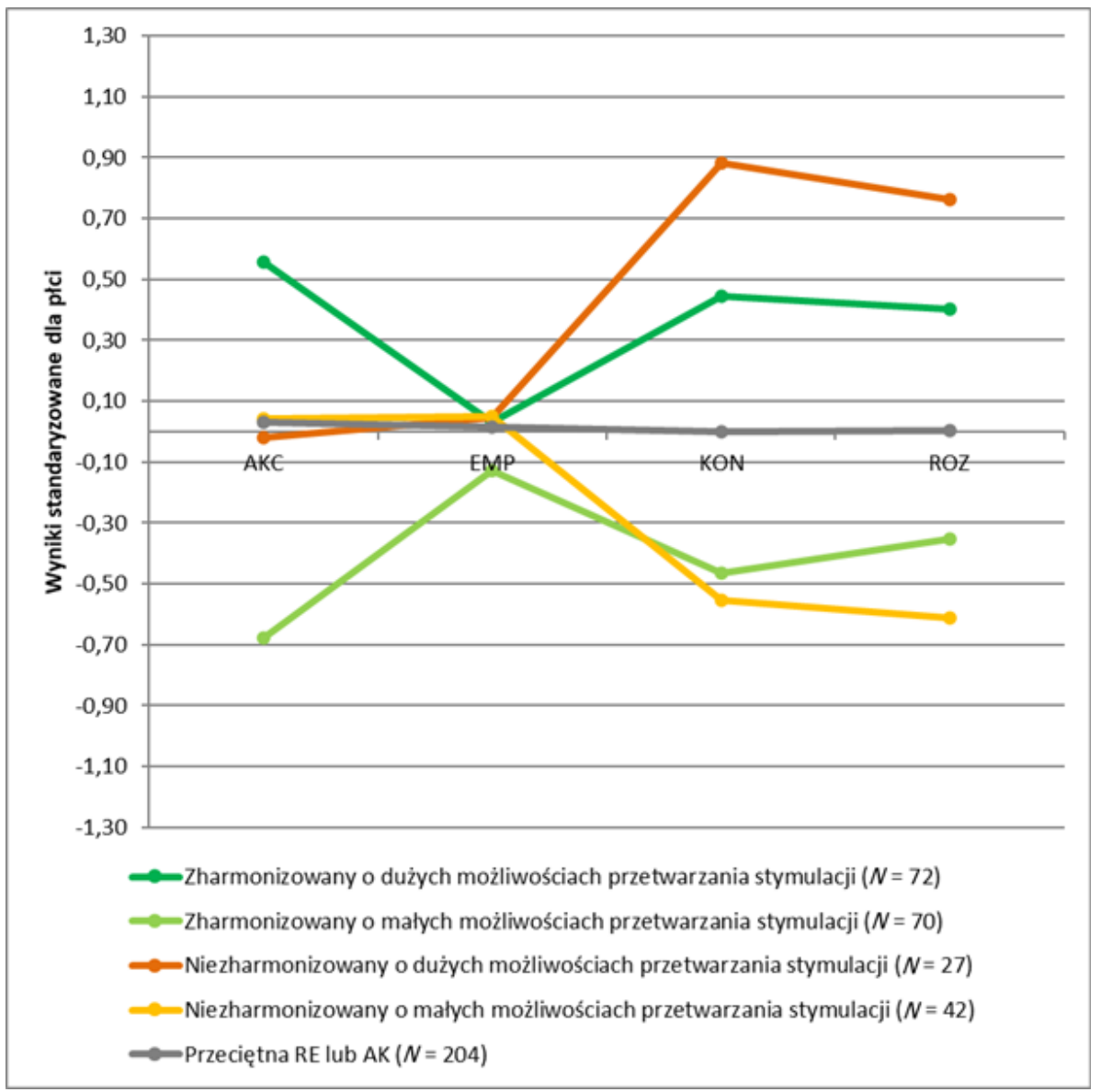

Rysunek 7. Uśrednione wyniki PKIE u kobiet o różnym profilu temperamentu.

Adnotacja. Skale PKIE: AKC - akceptowanie; EMP - empatia; KON - kontrola; ROZ - rozumienie. Skale FCZ-KT: RE - reaktywność emocjonalna; AK - aktywność.

Z przedstawionego rysunku widać, że empatia u kobiet nie zależy od profilu temperamentu, dlatego średnie poszczególnych profili temperamentu dla tej skali zbiegają się. Możliwości w zakresie przetwarzania stymulacji różnicują u kobiet poziom wyników w zakresie kontroli, rozumienia i akceptowania emocji, przy czym różnica w tej ostatniej zdolności jest widoczna tylko u osób posiadających zharmonizowaną strukturę temperamentu. 
W obrębie tych wyników widać tutaj zdecydowaną przewagę kobiet o dużych możliwościach przetwarzania stymulacji.

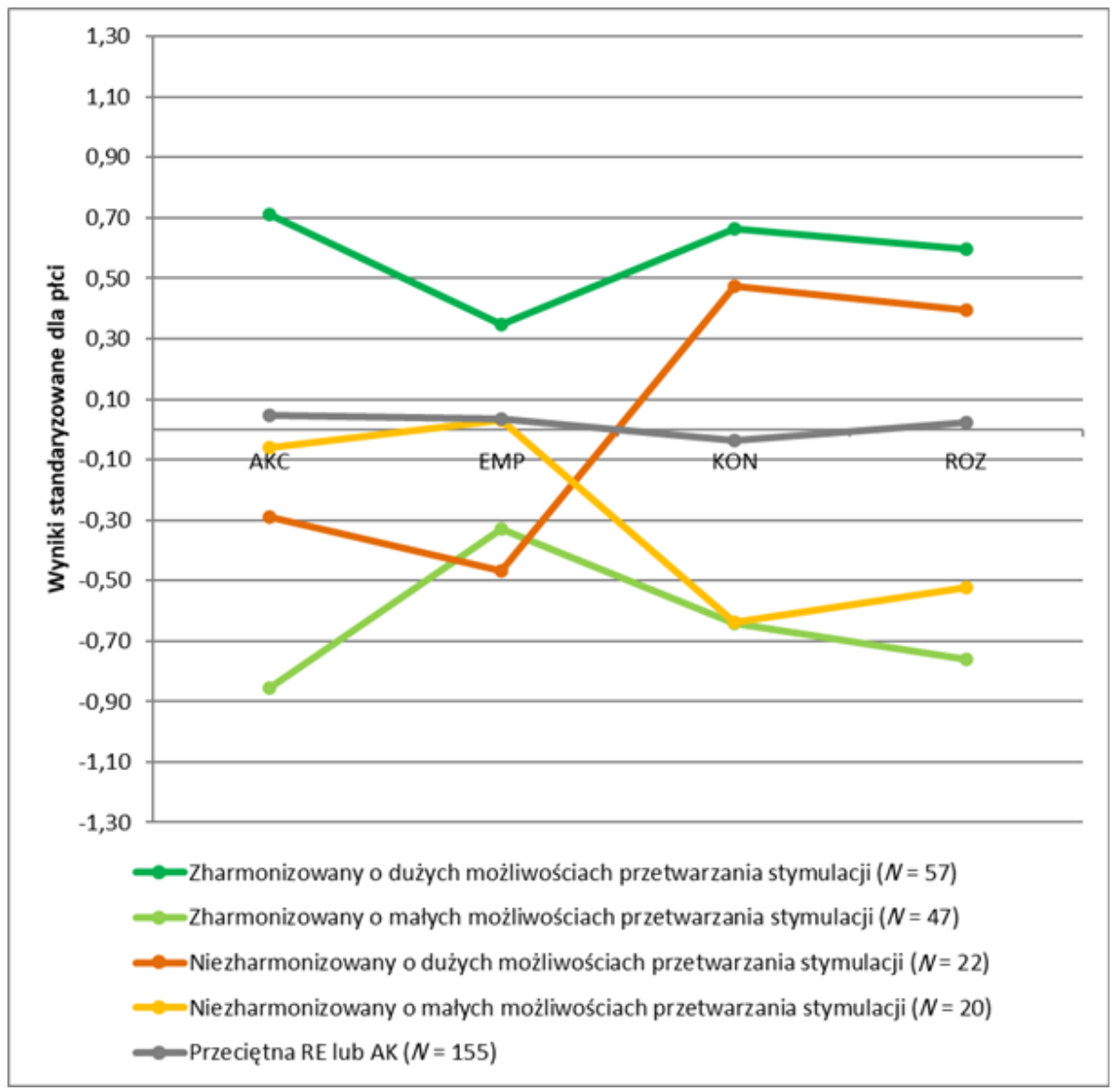

Rysunek 8. Uśrednione wyniki PKIE dla mężczyzn o różnym profilu temperamentu.

Adnotacja. Skale PKIE: AKC - akceptowanie; EMP - empatia; KON - kontrola; ROZ - rozumienie. Skale FCZ-KT: RE - reaktywność emocjonalna; AK - aktywność.

W przypadku mężczyzn profil temperamentu różnicuje poziom empatii, która jest najwyższa w przypadku zharmonizowanej struktury temperamentu przy dużych możliwościach przetwarzania stymulacji, zaś najniższa 
- w przypadku niezharmonizowanej struktury temperamentu o dużych możliwościach przetwarzania stymulacji. Mężczyźni o dużych możliwościach przetwarzania stymulacji, niezależnie od stopnia zharmonizowania struktury temperamentu, mają przewagę w zakresie kontroli i rozumienia emocji nad pozostałymi. Natomiast w przypadku takiej zdolności jak akceptacja emocji widzimy, że najlepiej wypadły tu osoby posiadające zharmonizowany typ temperamentu i duże możliwości przetwarzania stymulacji, następnie - osoby o niezharmonizowanym typie temperamentu i małych możliwościach przetwarzania stymulacji, potem - osoby mające niezharmonizowany typ temperamentu i duże możliwości przetwarzania stymulacji, i najsłabiej - osoby charakteryzujące się zharmonizowaną strukturą temperamentu i małymi możliwościami przetwarzania stymulacji. U mężczyzn zatem, w porównaniu z kobietami, wyniki w poziomie poszczególnych zdolności nie układają się tak jednoznacznie na korzyść osób o dużych możliwościach przetwarzania stymulacji.

\section{Uwarunkowania temperamentalne inteligencji emocjonalnej} doświadczeniowej i strategicznej. Dalsze analizy miały na celu uzyskanie odpowiedzi na pytanie, czy takie typy inteligencji emocjonalnej jak strategiczna i doświadczeniowa wiążą się z temperamentem. Uzyskane dane ilustrują rysunki 9 i 10. Przedstawiono na nich uśrednione wyniki dotyczące poszczególnych cech temperamentu dla kobiet i mężczyzn reprezentujących strategiczny lub doświadczeniowy rodzaj inteligencji emocjonalnej.

U mężczyzn rozbieżności pomiędzy wynikami dla poszczególnych parametrów temperamentu w profilach osób o przewadze zdolności emocjonalnych strategicznych lub doświadczeniowych są większe niż u kobiet (na to samo wcześniej wskazywała analiza kanoniczna). 


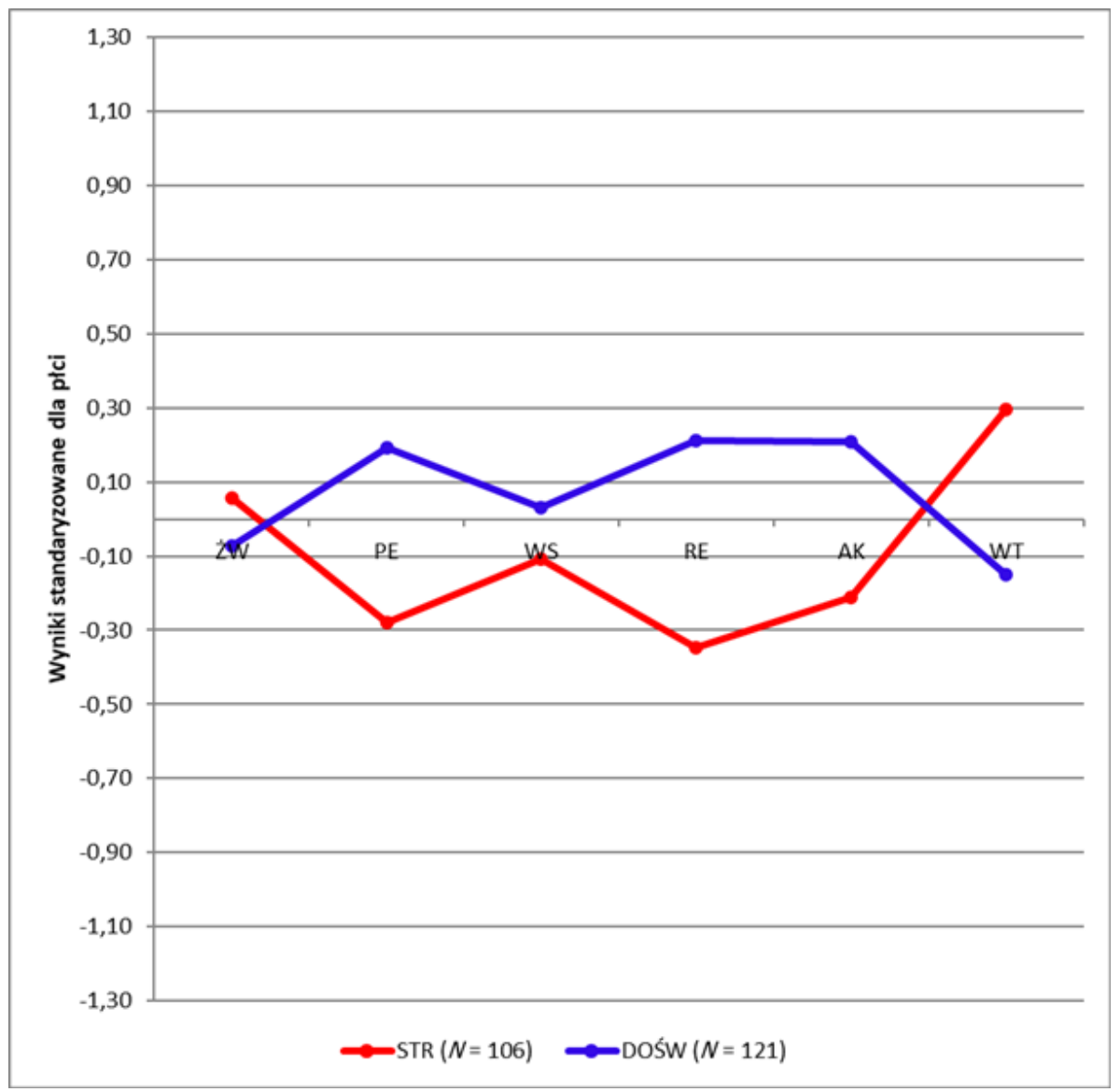

Rysunek 9. Uśredniony profil temperamentu u kobiet reprezentujących inteligencję emocjonalną strategiczną lub doświadczeniową.

Adnotacja. Skale FCZ-KT: ŻW - żwawość; PE - perseweratywność; WS - wrażliwość sensoryczna; RE - reaktywność emocjonalna; AK - aktywność; WT - wytrzymałość. 


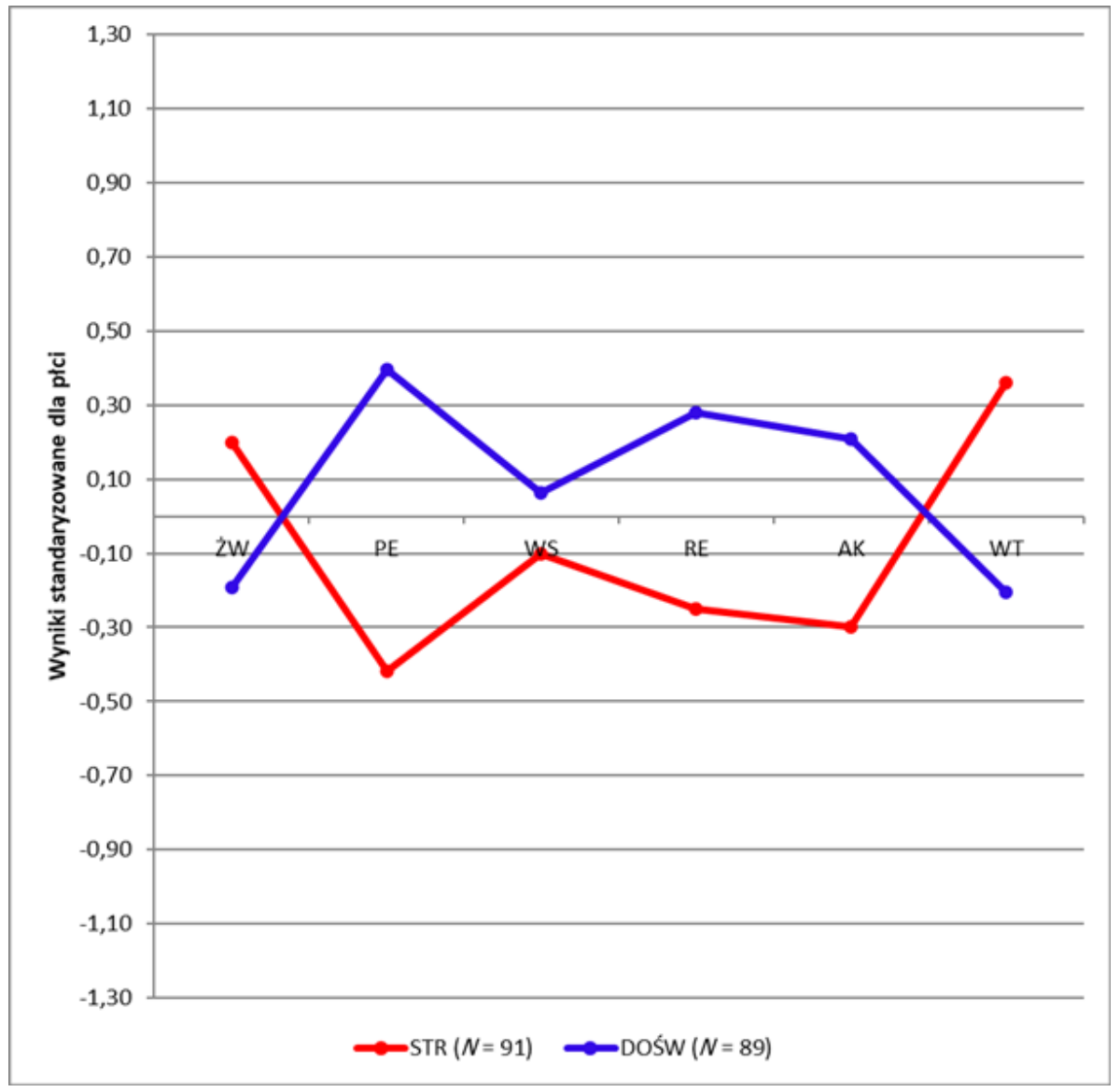

Rysunek 10. Uśredniony profil temperamentu u mężczyzn reprezentujących inteligencję emocjonalną strategiczną lub doświadczeniową.

Adnotacja. Skale FCZ-KT: ŻW - żwawość; PE - perseweratywność; WS - wrażliwość sensoryczna; RE - reaktywność emocjonalna; AK - aktywność; WT - wytrzymałość; STR - wysoka (lub przeciętna) inteligencja emocjonalna strategiczna; DOŚW - wysoka (lub przeciętna) inteligencja emocjonalna doświadczeniowa.

Następnie zbadano, w jakich proporcjach układa się występowanie profilów inteligencji emocjonalnej (strategiczna vs. doświadczeniowa) u osób o różnym typie struktury temperamentu w całej grupie badanych (załącznik D, tabela D2). W celu zweryfikowania, czy występują tutaj różnice 
zastosowano test dla wskaźników struktury, zwany też testem proporcji (Ferguson, Takane, 2002), polegający na porównaniu proporcji osób posiadających jakąś cechę w dwu próbach niezależnych ( $\mathrm{z}$ uwzględnieniem liczebności tych prób). Każde porównanie częstości występowania określonego profilu inteligencji emocjonalnej dotyczyło jednego wyodrębnionego profilu temperamentu w zestawieniu z pozostałymi profilami łącznie, np. osoby o zharmonizowanej strukturze temperamentu z dużymi możliwościami przetwarzania stymulacji zostały porównane ze wszystkimi osobami łącznie, które nie mają zharmonizowanej struktury temperamentu o dużych możliwościach przetwarzania stymulacji, czyli mają jeden z pozostałych profili temperamentu (zharmonizowany o małych możliwościach przetwarzania stymulacji, niezharmonizowany o dużych możliwościach przetwarzania stymulacji, niezharmonizowany o małych możliwościach przetwarzania stymulacji lub przeciętny).

U osób o zharmonizowanym profilu temperamentu z dużymi możliwościami przetwarzania stymulacji nieco rzadziej niż w innych profilach temperamentu wystąpił profil z przewagą inteligencji emocjonalnej doświadczeniowej. Wśród osób o niezharmonizowanej strukturze temperamentu i dużych możliwościach przetwarzania stymulacji, zdecydowanie częściej niż u osób o innym typie temperamentu, można znaleźć osoby o przewadze inteligencji emocjonalnej strategicznej. Oznacza to, że inteligencję strategiczną mają one zwykle bardziej rozwiniętą (na tle grupy) niż inteligencję doświadczeniową. W zdecydowanej większości przypadków mają one co najmniej przeciętny wynik zdolności do kontroli emocjonalnej i rozumienia emocji, a często jest to wynik wysoki (powyżej 0,5 odchylenia standardowego od średniej dla płci).

Dla osób o niezharmonizowanej strukturze temperamentu i małych możliwościach przetwarzania stymulacji wystąpiła przewaga doświadczeniowej inteligencji emocjonalnej nad strategiczną, choć uzyskały one przeciętne wyniki w akceptacji i empatii oraz niskie w kontroli i rozumieniu.

Niezróżnicowany profil temperamentu, czyli osoby o reaktywności lub aktywności nie odbiegającej od średniej dla płci o więcej niż pół odchylenia standardowego, nie wyróżniły się częstszym występowaniem jakiegoś profilu inteligencji emocjonalnej.

W odniesieniu do interakcji zharmonizowania struktury temperamentu i możliwości przetwarzania stymulacji w całej grupie badanych okazało 
się, że brak zharmonizowania struktury temperamentu u osób o dużych możliwościach przetwarzania stymulacji objawił się przewagą inteligencji emocjonalnej strategicznej nad doświadczeniową, zaś u osób o małych możliwościach przetwarzania stymulacji - przewagą inteligencji emocjonalnej doświadczeniowej nad strategiczną. Zatem na podstawie danych dotyczących ogółu badanych można stwierdzić, że możliwości przetwarzania stymulacji odpowiadają za poziom inteligencji emocjonalnej, a w interakcji ze stopniem zharmonizowania temperamentu skutkują zróżnicowaniem profilowym zdolności emocjonalnych u osób o różnym typie temperamentu. Zróżnicowanie profilowe ujawnia się wewnątrz grup wyodrębnionych ze względu na możliwości przetwarzania stymulacji, jednak nadal osoby o dużych możliwościach przetwarzania stymulacji wykazują przewagę w inteligencji emocjonalnej doświadczeniowej i strategicznej nad osobami o małych możliwościach przetwarzania stymulacji.

W dalszej kolejności zestawiono proporcje występowania profilów inteligencji emocjonalnej strategicznej i doświadczeniowej w grupach osób o różnym profilu temperamentu z uwzględnieniem podziału na płeć. Wyniki tych analiz przedstawiają tabele 16 i 17.

Tabela 16

Proporcje kobiet o określonym profilu inteligencji emocjonalnej w grupach o poszczególnych typach temperamentu

\begin{tabular}{ccrcccc}
\hline Profil & Zh DM & Zh MM & NZh DM & NZh MM & $\begin{array}{c}\text { Nieokre- } \\
\text { ślony }\end{array}$ & Ogółem \\
\hline STR & $58,5 \%^{*}$ & $50,0 \%$ & $94,1 \%^{* * *}$ & $8,3 \%^{* * *}$ & $42,2 \%$ & $46,7 \%$ \\
DOŚW & $41,5 \%^{*}$ & $50,0 \%$ & $5,9 \%^{* * *}$ & $91,7 \%^{* * *}$ & $57,8 \%$ & $53,3 \%$ \\
Ogółem & $100,0 \%$ & $100,0 \%$ & $100,0 \%$ & $100,0 \%$ & $100,0 \%$ & $100,0 \%$ \\
\hline
\end{tabular}

Adnotacja. STR - wysoka (lub przeciętna) inteligencja emocjonalna strategiczna; DOŚW - wysoka (lub przeciętna) inteligencja emocjonalna doświadczeniowa; Zh DM- struktura zharmonizowana w połączeniu z dużymi możliwościami przetwarzania stymulacji; Zh MM- struktura zharmonizowana w połączeniu z małymi możliwościami przetwarzania stymulacji; Nzh DM - struktura niezharmonizowana w połączeniu z dużymi możliwościami przetwarzania stymulacji; Nzh MM - struktura niezharmonizowana w połączeniu $\mathrm{z}$ małymi możliwościami przetwarzania stymulacji.

${ }^{\star} p<0,05 ;{ }^{* * *} p<0,001$. 
Tabela 17

Proporcje mężczyzn o określonym profilu inteligencji emocjonalnej wewnątrz grup o poszczególnych typach temperamentu

\begin{tabular}{crrcrcr}
\hline Profil & Zh DM & Zh MM & NZh DM & NZh MM & $\begin{array}{c}\text { Niezróż- } \\
\text { nicowany }\end{array}$ & Ogółem \\
\hline STR & $60,7 \%$ & $51,7 \%$ & $87,5 \%^{* * *}$ & $0,0 \%^{* * *}$ & $47,4 \%$ & $50,6 \%$ \\
DOŚW & $39,3 \%$ & $48,3 \%$ & $12,5 \%^{* * *}$ & $100,0 \%^{* * *}$ & $52,6 \%$ & $49,4 \%$ \\
Ogółem & $100,0 \%$ & $100,0 \%$ & $100,0 \%$ & $100,0 \%$ & $100,0 \%$ & $100,0 \%$ \\
\hline
\end{tabular}

Adnotacja. STR - wysoka (lub przeciętna) inteligencja emocjonalna strategiczna; DOŚW - wysoka (lub przeciętna) inteligencja emocjonalna doświadczeniowa; Zh DM- struktura zharmonizowana w połączeniu z dużymi możliwościami przetwarzania stymulacji; Zh MM- struktura zharmonizowana w połączeniu z małymi możliwościami przetwarzania stymulacji; Nzh DM - struktura niezharmonizowana w połączeniu z dużymi możliwościami przetwarzania stymulacji; Nzh MM - struktura niezharmonizowana $\mathrm{w}$ połączeniu $\mathrm{z}$ małymi możliwościami przetwarzania stymulacji.

${ }^{*} p<0,05 ;{ }^{* *} p<0,01 ;{ }^{* * *} p<0,001$.

Gdy wzięto pod uwagę mniej liczebne próby jednopłciowe, okazało się, że część różnic istotnych w całej próbie utraciła swoją istotność: częstsze występowanie u kobiet i mężczyzn o zharmonizowanym profilu temperamentu i dużych możliwościach przetwarzania stymulacji profilu inteligencji emocjonalnej strategicznej stało się nieistotne i przestało mieć znaczenie. U kobiet i u mężczyzn o niezharmonizowanym profilu temperamentu z dużymi możliwościami przetwarzania stymulacji ujawniło się częstsze występowanie strategicznej inteligencji emocjonalnej i rzadsze - doświadczeniowej inteligencji emocjonalnej. Z kolei u kobiet i mężczyzn o niezharmonizowanym profilu temperamentu z małymi możliwościami przetwarzania stymulacji ujawniło się częstsze występowanie doświadczeniowej inteligencji emocjonalnej i rzadsze - strategicznej inteligencji emocjonalnej. Takie rezultaty są zbieżne z uzyskanymi w całej próbie, bez uwzględniania podziału na płeć.

Okazało się, że duże możliwości przetwarzania stymulacji wiążą się z wyższym poziomem wyników w poszczególnych zdolnościach inteligencji emocjonalej w całej próbie. Przy uwzględnieniu podziału na płeć przewaga 
osób o dużych możliwościach przetwarzania stymulacji w zakresie inteligencji emocjonalnej ujawniła się we wszystkich czterech zdolnościach inteligencji emocjonalnej uwzględnionych w PKIE u mężczyzn i w trzech zdolnościach występujących w PKIE u kobiet, takich jak kontrola, rozumienie i akceptacja emocji (przy braku istotnych różnic w zakresie empatii emocjonalnej).

Uwarunkowania temperamentalne poznawczej i działaniowej inteligencji emocjonalnej. Dla wskaźnika przewagi komponentu poznawczego nad działaniowym inteligencji emocjonalnej (tzw. zmienna „przewaga POZN”, o której była mowa wcześniej - rozdział 4.2.) obliczono średnie i odchylenia standardowe w zależności od profilu temperamentu (tabela 18).

Tabela 18

Średnie i odchylenia standardowe zmiennej „przewaga komponentu poznawczego nad działaniowym" w zależności od profilu temperamentu

\begin{tabular}{|c|c|c|c|c|}
\hline \multirow[b]{2}{*}{ Profil temperamentu } & \multicolumn{2}{|c|}{ Kobiety } & \multicolumn{2}{|c|}{ Mężczyźni } \\
\hline & $M$ & $S D$ & $M$ & $S D$ \\
\hline $\begin{array}{l}\text { Zharmonizowany o dużych możli- } \\
\text { wościach przetwarzania stymulacji }\end{array}$ & $-0,28$ & 0,74 & $-0,22$ & 0,60 \\
\hline $\begin{array}{l}\text { Zharmonizowany o małych możliwo- } \\
\text { ściach przetwarzania stymulacji }\end{array}$ & 0,33 & 0,70 & 0,20 & 0,77 \\
\hline $\begin{array}{l}\text { Niezharmonizowany o dużych moż- } \\
\text { liwościach przetwarzania stymulacji }\end{array}$ & $-0,03$ & 0,59 & $-0,13$ & 0,55 \\
\hline $\begin{array}{l}\text { Niezharmonizowany o małych możli- } \\
\text { wościach przetwarzania stymulacji }\end{array}$ & $-0,03$ & 0,52 & 0,10 & 0,87 \\
\hline $\begin{array}{l}\text { Niezróżnicowany (przeciętna RE lub } \\
\text { AK) }\end{array}$ & 0,00 & 0,73 & 0,02 & 0,68 \\
\hline
\end{tabular}

Adnotacja. Wartość dodatnia średniej - przewaga komponentu poznawczego IE nad komponentem działaniowym; wartość ujemna średniej - przewaga komponentu działaniowego IE nad poznawczym. 
Dodatnie wskaźniki przewagi komponentu poznawczego nad działaniowym występują u obu grup cechujących się zharmonizowanym profilem temperamentu i małymi możliwościami przetwarzania stymulacji, a także u mężczyzn cechujących się niezharmonizowanym profilem temperamentu i małymi możliwościami przetwarzania stymulacji.

Aby się przekonać, czy nie należy tego przypisać przypadkowi, wykonano test $U$ Manna-Whitneya sprawdzający istotność różnic między grupami o małych i dużych możliwościach przetwarzania stymulacji. Stwierdzono, zarówno u kobiet, jak i u mężczyzn posiadających zharmonizowany typ temperamentu i duże możliwości przetwarzania stymulacji, przewagę komponentu działaniowego nad poznawczym. Również u mężczyzn posiadających niezharmonizowany typ temperamentu i duże możliwości przetwarzania stymulacji wystąpiła przewaga komponentu działaniowego nad poznawczym.

W przypadku kobiet o niezharmonizowanym profilu temperamentu i dużych możliwościach przetwarzania stymulacji oraz o niezharmonizowanym profilu temperamentu i małych możliwościach przetwarzania stymulacji przewaga występowania komponentu działaniowego nad poznawczym przyjęła bardzo niską wartość $(-0,03)$, co może sugerować, iż wynik ten jest przypadkowy.

Jak widać, istnieje różnica między osobami o dużych i małych możliwościach przetwarzania stymulacji w zakresie poznawczej i działaniowej inteligencji emocjonalnej. Osoby o małych możliwościach przetwarzania stymulacji charakteryzją się wyższą inteligencją emocjonalną poznawczą.

$\mathrm{Na}$ dalszym etapie analiz porównano kobiety i mężczyzn o małych i dużych możliwościach przetwarzania stymulacji pod względem poziomu przewagi komponentu poznawczego nad działaniowym; wyniki są przedstawione w tabeli 19, zaś dla wszystkich badanych - w załączniku D (tabela D3). 


\section{Tabela 19}

Porównanie kobiet i mężczyzn o dużych $\left(\mathrm{N}_{k}=99, \mathrm{~N}_{m}=79\right)$ i małych możliwościach $\left(\mathrm{N}_{k}=112, \mathrm{~N}_{m}=67\right)$ przetwarzania stymulacji pod względem przewagi komponentu poznawczego nad działaniowym inteligencji emocjonalnej

\begin{tabular}{|c|c|c|c|c|c|}
\hline Zmienna & Płeć & $\begin{array}{c}\text { DM } \\
\text { śr. ranga }\end{array}$ & $\begin{array}{c}\text { MM } \\
\text { śr. ranga }\end{array}$ & $\boldsymbol{U}$ & Efekt $r$ \\
\hline Przewaga & $\mathrm{K}$ & 86,77 & 123,00 & $3640,0^{* * *}$ & 0,30 \\
\hline POZN & $M$ & 64,73 & 83,84 & $1954,0^{* *}$ & 0,23 \\
\hline
\end{tabular}

Adnotacja. $N_{\mathrm{k}}$ - liczba kobiet; $N_{\mathrm{m}}$ - liczba mężczyzn; Przewaga POZN - przewaga komponentu poznawczego nad działaniowym; DM - osoby o dużych możliwościach przetwarzania stymulacji; MM - osoby o małych możliwościach przetwarzania stymulacji. ${ }^{* *} p<0,01 ;{ }^{* * *} p<0,001$.

Kobiety i mężczyźni o małych możliwościach przetwarzania stymulacji, w porównaniu z osobami o dużych możliowściach przetwarzania stymulacji, uzyskali wyższy poziom zmiennej „przewaga komponentu poznawczego nad działaniowym".

Kolejne analizy dotyczyły porównania testem dla wskaźników struktury (o którym była już mowa wcześniej) częstości występowania osób o przewadze komponentu poznawczego inteligencji emocjonalnej nad działaniowym oraz osób o przewadze komponentu działaniowego inteligencji emocjonalnej nad poznawczym wewnątrz poszczególnych typów profili temperamentu dla wszystkich badanych (załącznik D, tabela D4) w grupie kobiet (tabela 20) i w grupie mężczyzn (tabela 21). 
Tabela 20

Porównanie kobiet z przewaga komponentu działaniowego nad poznawczym $(\mathrm{N}=101) z$ kobietami z przewaga komponentu poznawczego nad działaniowym $(\mathrm{N}=91)$ w zakresie cech temperamentu

\begin{tabular}{ccccc}
\hline & PD & PP & & \\
Zmienna & śr. ranga & śr. ranga & $\boldsymbol{U}$ & Efekt $\boldsymbol{r}$ \\
\hline ŻW & 98,69 & 94,07 & 4374,5 & 0,04 \\
PE & 92,43 & 101,02 & 4184,5 & 0,08 \\
WS & 92,48 & 100,96 & 4189,5 & 0,08 \\
RE & 83,81 & 110,59 & $3313,5^{* * *}$ & 0,24 \\
AK & 108,15 & 83,57 & $3418,5^{* *}$ & 0,22 \\
WT & 101,98 & 90,42 & 4042,0 & 0,10 \\
\hline
\end{tabular}

Adnotacja. Skale FCZ-KT: ŻW - żwawość; PE - perseweratywność; WS - wrażliwość sensoryczna; RE - reaktywność emocjonalna; AK - aktywność; WT - wytrzymałość; PD - osoby o przewadze komponentu działaniowego nad komponentem poznawczym IE; PP - osoby o przewadze aspektu poznawczego nad aspektem działaniowym IE. ${ }^{* *} p<0,01 ;{ }^{* * *} p<0,001$.

\section{Tabela 21}

Porównanie mężczyzn z przewaga komponentu działaniowego nad poznawczym $\left(\mathrm{N}_{m}=62\right) z$ mężczyznami $z$ przewaga komponentu poznawczego nad działaniowym $\left(\mathrm{N}_{m}=66\right)$ w zakresie cech temperamentu

\begin{tabular}{|c|c|c|c|c|}
\hline & PD & PP & & \\
\hline Zmienna & śr. ranga & śr. ranga & $U$ & Efekt $r$ \\
\hline$\dot{Z} W$ & 67,25 & 61,92 & 1875,5 & 0,07 \\
\hline PE & 58,99 & 69,67 & 1704,5 & 0,14 \\
\hline WS & 55,18 & 73,26 & $1468,0^{* *}$ & 0,24 \\
\hline RE & 52,55 & 75,73 & $1305,0^{* * *}$ & 0,31 \\
\hline
\end{tabular}




\begin{tabular}{|c|c|c|c|c|}
\hline & PD & PP & & \\
\hline Zmienna & śr. ranga & śr. ranga & $U$ & Efekt $r$ \\
\hline AK & 70,27 & 59,08 & 1688,0 & 0,15 \\
\hline WT & 69,63 & 59,68 & 1728,0 & 0,13 \\
\hline
\end{tabular}

Adnotacja. Skale FCZ-KT: ŻW - żwawość; PE - perseweratywność; WS - wrażliwość sensoryczna; RE - reaktywność emocjonalna; AK - aktywność; WT - wytrzymałość; PD - osoby o przewadze komponentu działaniowego nad komponentem poznawczym IE; PP - osoby o przewadze aspektu poznawczego nad aspektem działaniowym IE. ${ }^{* *} p<0,01 ;{ }^{* * *} p<0,001$.

Osoby o zharmonizowanej strukturze temperamentu z dużymi możliwościami przetwarzania stymulacji wyróżniały się na tle osób o innych profilach temperamentu częstszą przewagą komponentu działaniowego nad poznawczym i rzadszą przewagą komponentu poznawczego nad działaniowym.

Wśród osób o zharmonizowanej strukturze temperamentu i małych możliwościach przetwarzania stymulacji, częściej niż w pozostałych typach struktury temperamentu, występowała przewaga komponentu poznawczego inteligencji emocjonalnej nad jej komponentem działaniowym oraz istotnie rzadziej - przewaga działaniowego nad poznawczym.

Okazało się, że u kobiet i mężczyzn istotna jest różnica w poziomie reaktywności emocjonalnej - wyższa reaktywność cechowała osoby o przewadze komponentu poznawczego nad działaniowym. Ponadto mężczyźni o przewadze komponentu poznawczego inteligencji emcojonalnej uzyskali istotnie wyższe wyniki w zakresie wrażliwości sensorycznej, zaś kobiety o przewadze komponentu działaniowego inteligencji emocjonalnej uzyskały istotnie wyższe wyniki w zakresie aktywności. Zestawienie proporcji obu typów relacji między komponentem poznawczym a działaniowym w obrębie inteligencji emocjonalnej w grupach różniących się profilem temperamentu widoczne jest w tabelach 22 (dla kobiet) i 23 (dla mężczyzn). W załączniku D (tabela D5) zainteresowany Czytelnik znajdzie wyniki dla ogółu badanych w omawianym kontekście. 
Tabela 22

Proporcje kobiet o określonej relacji między aspektami inteligencji emocjonalnej wewnątrz grup o poszczególnych profilach temperamentu

\begin{tabular}{ccccccc}
\hline $\begin{array}{c}\text { Relacja } \\
\text { między } \\
\text { aspek- } \\
\text { tami }\end{array}$ & Zh DM & Zh MM & NZh DM & NZh MM & $\begin{array}{c}\text { Przecięt- } \\
\text { ny }\end{array}$ & Ogółem \\
\hline PD & $79,4 \%^{* * *}$ & $25,0 \%^{* * *}$ & $58,3 \%$ & $66,7 \%$ & $50,5 \%$ & $52,6 \%$ \\
PP & $20,6 \%^{* * *}$ & $75,0 \%^{* * *}$ & $41,7 \%$ & $33,3 \%$ & $49,5 \%$ & $47,4 \%$ \\
Ogółem & $100,0 \%$ & $100,0 \%$ & $100,0 \%$ & $100,0 \%$ & $100,0 \%$ & $100,0 \%$ \\
\hline
\end{tabular}

Adnotacja. Zh - struktura zharmonizowana; NZh - struktura niezharmonizowana; DM - osoby o dużych możliwościach przetwarzania stymulacji; MM - osoby o małych możliwościach przetwarzania stymulacji; PD - osoby o przewadze komponentu działaniowego nad komponentem poznawczym inteligencji emocjonalnej; PP - osoby o przewadze aspektu poznawczego nad aspektem działaniowym inteligencji emocjonalnej. ${ }^{* * *} p<0,001$.

\section{Tabela 23}

Proporcje mężczyzn o określonej relacji między aspektami IE wewnątrz grup o poszczególnych profilach temperamentu

\begin{tabular}{|c|c|c|c|c|c|c|}
\hline $\begin{array}{c}\text { Relacja } \\
\text { między } \\
\text { aspek- } \\
\text { tami }\end{array}$ & Zh DM & Zh MM & NZh DM & NZh MM & $\begin{array}{c}\text { Przecięt- } \\
\text { ny }\end{array}$ & Ogółem \\
\hline PD & $65,2 \% * *$ & $32,0 \% *$ & $60,0 \%$ & $50,0 \%$ & $47,6 \%$ & $48,4 \%$ \\
\hline PP & $34,8 \% * *$ & $68,0 \% *$ & $40,0 \%$ & $50,0 \%$ & $52,4 \%$ & $51,6 \%$ \\
\hline Ogółem & $100,0 \%$ & $100,0 \%$ & $100,0 \%$ & $100,0 \%$ & $100,0 \%$ & $100,0 \%$ \\
\hline \multicolumn{7}{|c|}{$\begin{array}{l}\text { Adnotacja. Zh - struktura zharmonizowana; NZh - struktura niezharmonizowana; } \\
\text { mo - osoby o dużych możliwościach przetwarzania stymulacji; } \mathrm{MM} \text { - osoby o małych } \\
\text { nożliwościach przetwarzania stymulacji; } \mathrm{PD} \text { - osoby o przewadze komponentu działa- } \\
\text { iowego nad komponentem poznawczym inteligencji emocjonalnej; } \mathrm{PP} \text { - osoby o prze- } \\
\text { vadze aspektu poznawczego nad aspektem działaniowym inteligencji emocjonalnej. } \\
p<0,05 ;{ }^{* *} p<0,01 \text {. }\end{array}$} \\
\hline
\end{tabular}


Przewaga emocjonalnego komponentu działaniowego istotnie częściej niż w innych profilach temperamentu występowała u kobiet i mężczyzn o zharmonizowanym profilu temperamentu i dużych możliwościach przetwarzania stymulacji. Przewaga emocjonalnego komponentu poznawczego istotnie częściej występowała u kobiet i mężczyzn o zharmonizowanym profilu temperamentu i małych możliwościach przetwarzania stymulacji. Uśrednione profile temperamentu kobiet i mężczyzn o przewadze komponentu poznawczego lub działaniowego inteligencji emocjonalnej przedstawione są na kolejnych rysunkach (rysunek 11 i rysunek 12). 


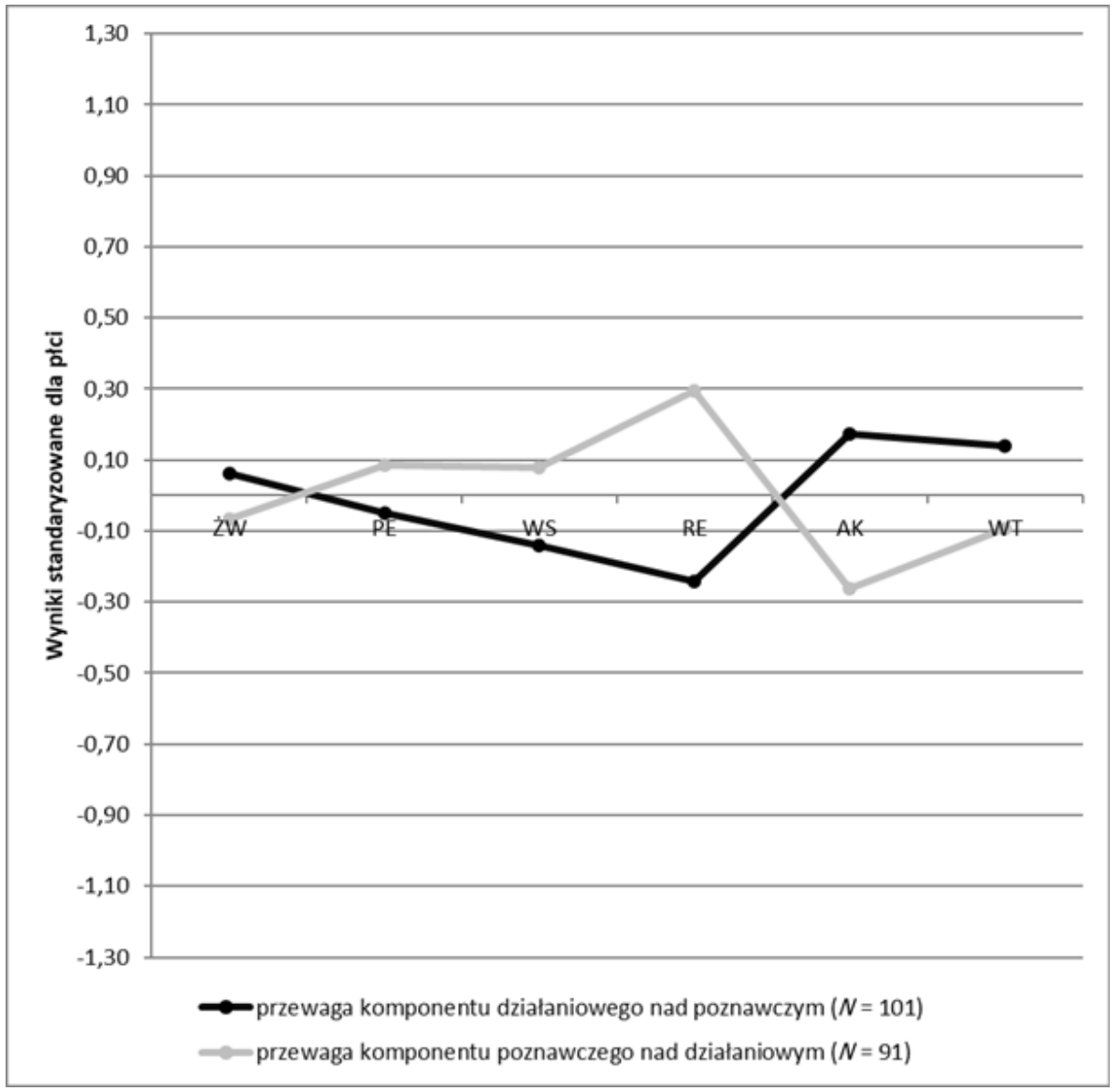

Rysunek 11. Uśrednione profile temperamentu u kobiet o przewadze komponentu poznawczego lub działaniowego inteligencji emocjonalnej.

Adnotacja. Skale FCZ-KT: ŻW - żwawość; PE - perseweratywność; WS - wrażliwość sensoryczna; RE - reaktywność emocjonalna; AK - aktywność; WT - wytrzymałość.

Na powyższym rysunku dotyczącym kobiet widoczna jest zwiększona odległość między średnimi dla reaktywności emocjonalnej i aktywności tak jak wskazał test $U$ Manna-Whitneya. 


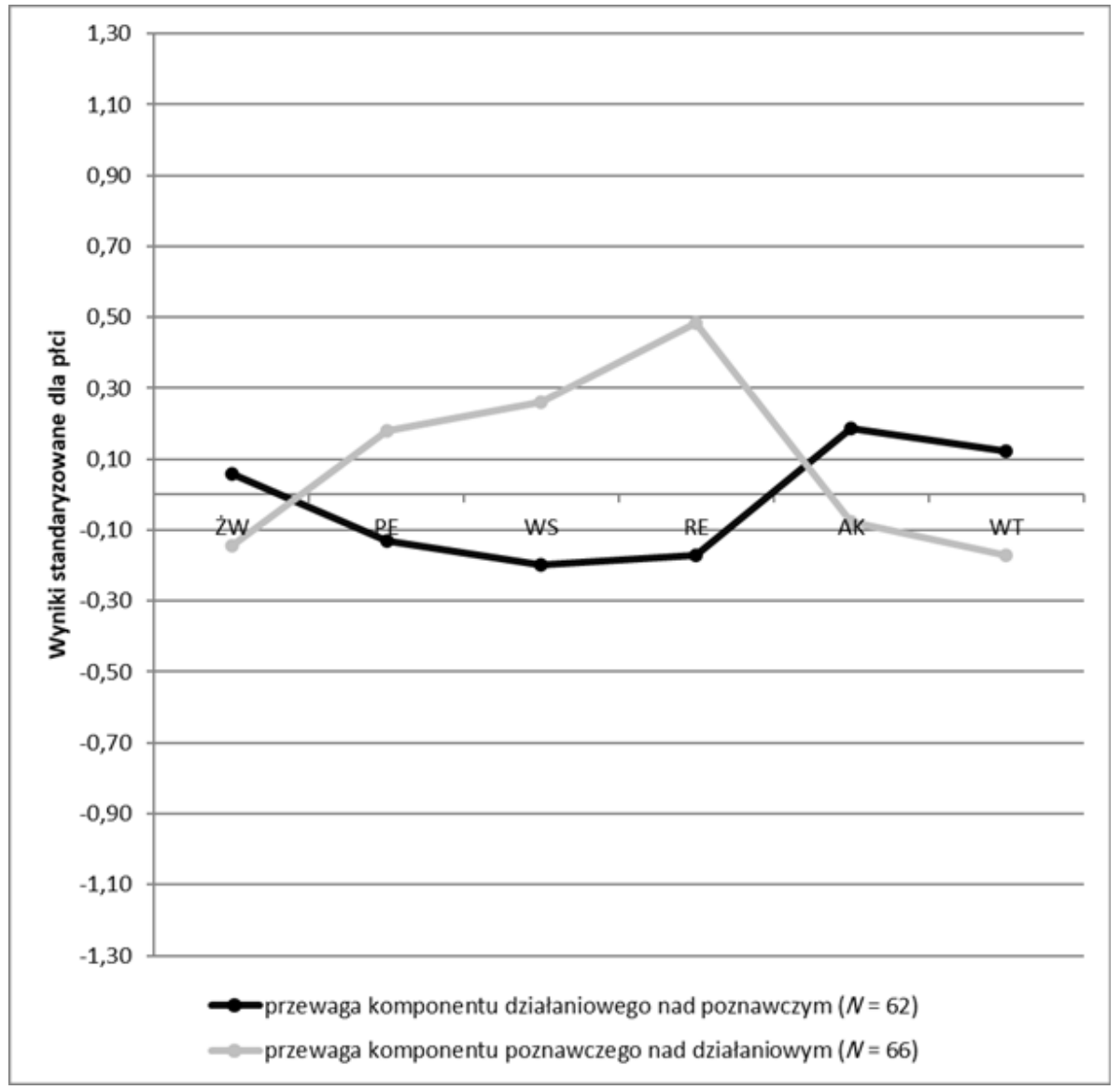

Rysunek 12. Uśrednione profile temperamentu u mężczyzn o przewadze komponentu poznawczego lub działaniowego inteligencji emocjonalnej. Adnotacja. Skale FCZ-KT: ŻW - żwawość; PE - perseweratywność; WS - wrażliwość sensoryczna; RE - reaktywność emocjonalna; AK - aktywność; WT - wytrzymałość.

U mężczyzn kształt profilu temperamentu, w którym występuje przewaga komponentu działaniowego inteligencji emocjonalnej nad poznawczym, jest podobny jak u kobiet. Natomiast kształt profilu temperamentu kobiet i mężczyzn o przewadze komponentu poznawczego nad działaniowym jest różny - średnie reaktywności emocjonalnej, wrażliwości sensorycznej i perseweratywności w większym stopniu odbiegają w górę od przeciętnej 
w grupie mężczyzn niż analogiczne wyniki u kobiet. Przy tym różnica w poziomie perseweratywności nie jest jednak istotna.

6.5.6. Dyskusja. Głównym celem tej części pracy było ukazanie zależności pomiędzy temperamentem a inteligencją emocjonalną. Punktem wyjścia była tutaj koncepcja Matczak (2004a), opierająca się na założeniu, że istotą inteligencji emocjonalnej jest łączenie emocji z poznaniem. Emocje są poddawane refleksji poznawczej oraz same wspomagają tę refleksję. Rozwój inteligencji emocjonalnej na skutek interakcji procesów emocjonalnych i poznawczych ma miejsce w takich sytuacjach, w których aktywność człowieka sprzyja powstawaniu emocji, a zarazem powstawaniu refleksji nad nimi. Szczególne znaczenie mają tutaj aktywność zadaniowa i społeczna. Aktywność zadaniowa wiąże się z osiąganiem celów, których szacowana wartość odzwierciedla się w emocjach jednostki, stąd aktywność zadaniowa jest silnie emocjogenna. Aktywność społeczna z kolei odnosi się do kontaktów społecznych. W aktywności społecznej inni ludzie stanowią silne źródło emocji dla jednostki, zarazem odzwierciedlając jej emocje i dostarczając sprzężeń zwrotnych. Według koncepcji Matczak inteligencja emocjonalna może rozwijać się wtedy, kiedy jednostka podejmuje aktywność zadaniową lub społeczną, rodzącą emocje. Rozwój inteligencji emocjonalnej, jako efekt aktywności jednostki, jest ściśle związany z temperamentem, który wpływa na intensywność, poziom i rodzaj podejmowanej aktywności (Matczak, 2004b).

Podjęłam próbę zanalizowania zależności między temperamentem a inteligencją emocjonalną, wyodrębniając zarówno typy temperamentu, jak i profile inteligencji emocjonalnej. Uzyskane przeze mnie wyniki o tyle nie zaskakują, co są w jakimś stopniu zbliżone do wyników uzyskanych we wcześniejszych badaniach uwzględniających cechy temperamentu z Regulacyjnej Teorii Temperamentu (skądinąd badań tych było do tej pory niewiele). Cechami temperamentu, które ujawniały najsilniejszy związek $\mathrm{z}$ inteligencją emocjonalną $\mathrm{w}$ dotychczasowych badaniach były aktywność i żwawość (związek dodatni) oraz reaktywność emocjonalna (związek ujemny), zaś nieco mniej konsekwentnie - również wrażliwość sensoryczna (związek dodatni). Innymi słowy, osoby o wysokiej aktywności, żwawości i wrażliwości sensorycznej miały wyższą inteligencję emocjonalną, zaś osoby „wysokoreaktywne” miały tę inteligencję niższą. 
W moich badaniach analizy korelacyjne ujawniły taki sam kierunek zależności. Wyniki ogólne pomiaru inteligencji emocjonalnej korelowały dodatnio ze żwawością, wrażliwością sensoryczną, aktywnością i wytrzymałością, a więc z cechami stanowiącymi o dużych możliwościach przetwarzania stymulacji, zaś ujemnie - z reaktywnością emocjonalną i perseweratywnością, a więc cechami stanowiącymi o małych możliwościach przetwarzania stymulacji. Wyniki w skali akceptowania (mierzącej działaniowy komponent inteligencji emocjonalnej doświadczeniowej), dotyczącej zdolności do akceptowania, wyrażania i wykorzystywania własnych emocji w działaniu, korelowały dodatnio ze żwawością, wrażliwością sensoryczną, aktywnością i wytrzymałością (analogicznie jak wyniki ogólne dla PKIE), ale nie ujawniły związków z reaktywnością emocjonalną i perseweratywnością. Wyniki w skali empatii (mierzącej komponent poznawczy inteligencji emocjonalnej doświadczeniowej), dotyczącej zdolności do rozumienia i rozpoznawania emocji u innych ludzi, korelowały dodatnio ze żwawością, wrażliwością sensoryczną i aktywnością. Nie pojawiły się tu istotne zależności z pozostałymi cechami temperamentu. Wyniki w skali rozumienia (będącej komponentem poznawczym inteligencji emocjonalnej strategicznej), dotyczącej zdolności do rozumienia i uświadamiania sobie swoich emocji, korelowały dodatnio ze żwawością, wrażliwością sensoryczną i wytrzymałością, zaś ujemnie z perseweratywnością i reaktywnością emocjonalną. Aktywność wydaje się mieć mniejsze znaczenie dla zdolności mierzonych tą skalą. Wyniki w skali kontroli (mierzącej komponent działaniowy inteligencji emocjonalnej strategicznej), dotyczącej zdolności do kontrolowania własnych emocji, korelowały dodatnio ze żwawością, wrażliwością sensoryczną, aktywnością i wytrzymałością, zaś ujemnie - z perseweratywnością i reaktywnością emocjonalną.

Postawiona przeze mnie hipoteza ogólna mówiąca o tym, że każdy z typów temperamentu będzie korzystniejszy dla innego typu inteligencji emocjonalnej nie potwierdziła się. W przeprowadzonych badaniach okazało się, że, zarówno dla poziomu zdolności należących do inteligencji emocjonalnej poznawczej, jak i dla poziomu zdolności wchodzących w zakres inteligencji emocjonalnej działaniowej, korzystniejsze są cechy temperamentu warunkujące duże możliwości przetwarzania stymulacji, a więc przede wszystkim wysoka aktywność oraz niska reaktywność emocjonalna. Dodatnie związki pomiędzy zdolnościami emocjonalnymi a tymi cechami temperamentu, 
których wysoki poziom definiuje duże możliwości przetwarzania stymulacji (żwawość, aktywność, wytrzymałość), mogą sugerować, że na poziom inteligencji emocjonalnej - niezależnie od tego, czy mowa jest o jej typie poznawczym, działaniowym, strategicznym, czy też doświadczeniowym korzystny wpływ mają duże możliwości przetwarzania stymulacji.

Dalsze badania korelacyjne z zastosowaniem analizy kanonicznej pozwoliły na uzyskanie bardziej precyzyjnych rezultatów. Najsilniejsza uzyskana zależność pomiędzy inteligencją emocjonalną a temperamentem występuje przede wszystkim pomiędzy reaktywnością emocjonalną i inteligencją emocjonalną strategiczną. Jest to związek ujemny. Umiarkowana zależność dotyczy dodatniego związku pomiędzy aktywnością a akceptacją emocji (a więc komponentem działaniowym inteligencji emocjonalnej należącym zarazem do inteligencji emocjonalnej doświadczeniowej). Słabsza niż pozostałe, ale nadal istotna zależność zachodzi pomiędzy wrażliwością sensoryczną a empatią (a więc komponentem poznawczym inteligencji emocjonalnej doświadczeniowej). Tak jak we wcześniej podejmowanych badaniach kwestionariuszowych na ten temat, lepsze rezultaty w obszarze inteligencji emocjonalnej utrzymały się u osób posiadających cechy temperamentu warunkujące duże możliwości przetwarzania stymulacji.

Ujemny związek pomiędzy inteligencją emocjonalną strategiczną a reaktywnością emocjonalną każe zastanowić się nad tym, czy wysoka reaktywność emocjonalna nie jest czynnikiem ograniczającym (w pewnym stopniu) rozwój inteligencji emocjonalnej do pewnego jej poziomu (którego osoby charakteryzujące się taką cechą temperamentu nie są w stanie przekroczyć). Inteligencja emocjonalna strategiczna odpowiada trzeciej i czwartej gałęzi zdolności w modelu inteligencji emocjonalnej Saloveya i Mayera. Należące do niej zdolności do rozumienia informacji emocjonalnych - tego jak emocje łączą się i zmieniają wraz z rozwojem relacji - oraz zdolności do regulowania uczuć zarówno u siebie, jak i innych, tak aby działać na rzecz osobistego zrozumienia i rozwoju, są zdolnościami „późniejszymi rozwojowo" niż zdolności inteligencji emocjonalnej doświadczeniowej do spostrzegania emocji u siebie i u innych, do generowania, wyrażania oraz odczuwania emocji niezbędnych do komunikowania uczuć oraz wykorzystywania ich w procesach poznawczych.

Inteligencja emocjonalna strategiczna - analizowanie i kontrolowanie emocji - wymaga także efektywnej regulacji poziomu pobudzenia 
(utrzymywania go na optymalnym poziomie). Ponadoptymalny poziom stymulacji występuje zwłaszcza u osób, u których występuje dysocjacja cech energetycznych temperamentu (wysoka reaktywność emocjonalna i wysoka aktywność). W literaturze pisze się o tym, że osoby charakteryzujące się niezharmonizowaną strukturą temperamentu wskazującą na małe możliwości przetwarzania stymulacji wykazują skłonność do zachowań impulsywnych, są wybuchowe i łatwo reagują gniewem (Zawadzki, Strelau, 1997), co świadczy o deficytach w zakresie takich zdolności jak regulacja i kontrola emocjonalna.

Zdolności inteligencji emocjonalnej doświadczeniowej, jako bardziej „pierwotnej” i wcześniejszej rozwojowo, wydają się zatem być „łatwiej osiągalne” dla osób wysokoreaktywnych, zaś zdolności „wyższego rzędu”, należące do późniejszej rozwojowo inteligencji emocjonalnej strategicznej, mogą być dla tych samych osób „trudniej osiągalne”. Analogicznie można przypuszczać, że u osób cechujących się niską reaktywnością ograniczenie tego rodzaju nie będzie występowało.

Jeśli chodzi o dodatni związek pomiędzy aktywnością a akceptacją emocji (zdolnością należącą do inteligencji emocjonalnej doświadczeniowej), „ograniczenie” dla rozwoju inteligencji emocjonalnej doświadczeniowej w postaci wysokiej reaktywności emocjonalnej (a więc temperamentu warunkującego małe możliwości przetwarzania stymulacji) nie jest tak silne. Inteligencja emocjonalna doświadczeniowa nie wymaga specjalnie dużej aktywności. „Słuchanie głosu emocji i podążanie za nim” jest raczej naturalne dla osób wysoko reaktywnych, pod warunkiem, że trening socjalizacyjny (na który są one bardziej podatne) nie zahamuje w nich tej cechy.

W literaturze psychologicznej można znaleźć dane mówiące o tym, że poznawczej koncentracji na bodźcach społecznych sprzyja nie tyle duże zapotrzebowanie na stymulację, ile duża wrażliwość na wzmocnienia społeczne, zwłaszcza kary, czyli wysoka reaktywność (por. Ogińska-Bulik, 1992). Było to jednym $\mathrm{z}$ argumentów, które skłoniły mnie do postawienia pytania o związek pomiędzy małymi możliwościami przetwarzania stymulacji a poznawczą inteligencją emocjonalną. Dotychczasowe badania empiryczne ujawniły następujące powiązania inteligencji emocjonalnej poznawczej z cechami temperamentu: dodatnie związki z wrażliwością sensoryczną, reaktywnością emocjonalną i perseweratywnością (cechami uznawanymi za decydujące o małych możliwościach przetwarzania stymulacji); przeciwnie 
- ujemny związek z perseweratywnością. Jednocześnie wykazały następujące zależności pomiędzy inteligencją emocjonalną działaniową a cechami temperamentu: dodatnie ze żwawością, aktywnością i wrażliwością sensoryczną (cechami uznawanymi za decydujące o dużych możliwościach przetwarzania stymulacji), zaś ujemne z reaktywnością emocjonalną. Zatem dane empiryczne na podejmowany przeze mnie temat, jakimi dysponowano do tej pory, sugerowały przypuszczenie, że korzystne znaczenie dla rozwoju inteligencji emocjonalnej mogą mieć zarówno cechy stanowiące o małym zapotrzebowaniu na stymulację (reaktywność emocjonalna), jak i te związane z dużym zapotrzebowaniem na nią (aktywność, żwawość).

W przeprowadzonych przeze mnie badaniach uzyskałam odmienne wyniki. Okazało się, że zarówno w zakresie inteligencji emocjonalnej poznawczej, jak i inteligencji emocjonalnej działaniowej osoby o małych możliwościach przetwarzania stymulacji uzyskały niższe wyniki w porównaniu z osobami o dużych możliwościach przetwarzania stymulacji. Taki wynik może zastanawiać i może świadczyć np. o specyfice mojej grupy badawczej (najczęściej występującym w niej typem temperamentu był zharmonizowany o dużych możliwościach przetwarzania stymulacji), którą stanowili głównie młodzi dorośli z wyższym wykształceniem lub w trakcie jego zdobywania, mieszkający przeważnie w dużych miastach.

Potwierdzenie w przeprowadzonych badaniach uzyskała hipoteza mówiąca o dodatnim związku wrażliwości sensorycznej z inteligencją emocjonalną. Istotnie, wrażliwość sensoryczna okazała się być parametrem temperamentu z RTT, dodatnio (choć słabo) związanym ze wszystkimi zastosowanymi skalami inteligencji emocjonalnej. Sugeruje to, że sprzyja ona rozwojowi wszystkich uwzględnionych w moich badaniach typów inteligencji emocjonalnej: doświadczeniowej i strategicznej, poznawczej i działaniowej. Wrażliwość sensoryczna oznacza „spostrzegawczość, czujność i otwartość na otoczenie" (por. Matczak, 2011), jest łatwością zauważania subtelnych zmian w otoczeniu oraz we własnym organiźmie, co dotyczy również „sygnałów emocjonalnych”.

Wykazywanie umiejętności dostrzegania tych sygnałów, rozróżniania ich oraz reagowania na nie nawet przez bardzo małe dzieci wskazuje, że zdolności emocjonalne są uwarunkowane biologicznie i do pewnego stopnia niezależne od rozwoju poznawczego. Percepcja emocji - bezpośrednio zależna od wrażliwości sensorycznej - należy do pierwszego poziomu 
zdolności inteligencji emocjonalnej wymienianych w modelu Saloveya i Mayera i warunkuje rozwój inteligencji emocjonalnej również na pozostałych trzech poziomach zdolności wchodzących w jej skład. Jak pisałam już o tym wcześniej, proces rozwoju inteligencji emocjonalnej rozpoczyna się od nauki identyfikowania własnych i cudzych emocji i przebiega aż po osiągnięcie świadomej kontroli i regulacji emocjonalnej. Na przykład, nie możemy rozumieć emocji, jeśli nie posiadamy zdolności ich adekwatnej percepcji. Stanowiłoby to wyjaśnienie ważności tego parametru temperamentu, jakim jest wrażliwość sensoryczna, dla wszystkich poziomów zdolności wchodzących w zakres inteligencji emocjonalnej.

Kolejne postawione hipotezy dotyczyły zróżnicowania profilowego inteligencji emocjonalnej osób o małych i dużych możliwościach przetwarzania stymulacji. Uzyskały one potwierdzenie wyrażające się w tym, że osoby o dużych możliwościach przetwarzania stymulacji częściej na tle własnej grupy wykazywały się przewagą komponentu działaniowego nad komponentem poznawczym inteligencji emocjonalnej; osoby o małych możliwościach przetwarzania stymulacji częściej w odniesieniu do własnej grupy wykazywały się przewagą komponentu poznawczego nad komponentem działaniowym inteligencji emocjonalnej.

Przewaga komponentu poznawczego inteligencji emocjonalnej nad działaniowym u osób o małych możliwościach przetwarzania stymulacji może być związana z ich wysoką perseweratywnością. Jest ona „czynnikiem refleksji”, co wynika z tego, że jako tendencja do kontynuowania i powtarzania reakcji po zaprzestaniu działania bodźca (czy istnienia sytuacji) dotyczy nie tylko sfery behawioralnej, ale również sfery poznawczej - osoby silnie perseweratywne mają tendencję do ruminacji myślowych, dłuższego „rozpamiętywania” tego, co się wydarzyło, tym samym rozwijając również refleksję w zakresie przeżywanych emocji własnych i cudzych. Osoby wysoko reaktywne uczą się trafnie rozpoznawać i rozumieć emocje, zwłaszcza innych osób, gdyż są bardziej ukierunkowane na wzmocnienia społeczne i wrażliwe na kary ze strony otoczenia społecznego, co przypuszczalnie zwiększa ich koncentrację poznawczą na bodźcach społecznych.

Porównania osób o dużych i małych możliwościach przetwarzania stymulacji pokazały konsekwentną przewagę osób o dużych możliwościach przetwarzania stymulacji nad osobami o małych możliwościach przetwarzania stymulacji, zarówno pod względem działaniowego, jak i poznawczego 
aspektu inteligencji emocjonalnej. Innymi słowy: pomimo że u osób o dużych możliwościach przetwarzania stymulacji „słabszą stroną” są zdolności w zakresie inteligencji emocjonalnej poznawczej, to i tak poziom zdolności w obrębie komponentu poznawczego inteligencji emocjonalnej jest u nich wyższy niż u osób o małych możliwościach przetwarzania stymulacji (chociaż zdolności inteligencji emocjonalnej poznawczej są u tych drugich „mocniejszą stroną").

Przyglądając się porównaniom wyników dotyczących inteligencji emocjonalnej pomiędzy grupą kobiet i mężczyzn z uwzględnieniem ich struktury temperamentu, można zauważyć, że u mężczyzn inteligencja emocjonalna w większym stopniu niż u kobiet zależy od możliwości przetwarzania stymulacji. Świadczą o tym np. wyniki w zakresie takiej zdolności emocjonalnej jak empatia. Wystąpiły tutaj zdecydowane różnice pomiędzy mężczyznami o dużych i małych możliwościach przetwarzania stymulacji na korzyść tych pierwszych. Natomiast w przypadku kobiet o dużych i małych możliwościach przetwarzania stymulacji różnice w poziomie empatii nie ujawniły się. Nie będę przytaczać w tym momencie wszystkich różnic w tym temacie - zostały one omówione szczegółowo w rozdziałach prezentujących wyniki badań własnych na poszczególnych etapach analiz.

W przypadku hipotezy na temat związku struktury temperamentu (zharmonizowanej lub niezharmonizowanej) z ogólnym poziomem inteligencji emocjonalnej, spodziewano się wyższego poziomu ogólnej inteligencji emocjonalnej u osób o zharmonizowanej strukturze temperamentu. Okazało się jednak, że sam rodzaj struktury temperamentu nie różnicuje wyników ogólnych pomiaru inteligencji emocjonalnej (ani wyników dotyczących poszczególnych zdolności emocjonalnych). Rodzaj struktury temperamentu ma natomiast znaczenie wtedy, kiedy bierze się pod uwagę również możliwości przetwarzania stymulacji: zharmonizowanie lub niezharmonizowanie struktury temperamentu w interakcji z możliwościami przetwarzania stymulacji różnicuje wyniki w zakresie zdolności inteligencji emocjonalnej.

Istotny był tu poziom aktywności u badanych. Miał on znaczenie zarówno w przypadku osób o dużych możliwościach przetwarzania stymulacji, jak i osób o małych możliwościach przetwarzania stymulacji: te z nich, które nieadekwatnie do swoich możliwości przetwarzania stymulacji podejmowały większą aktywność, uzyskiwały wyższe wyniki w zakresie zdolności inteligencji emocjonalnej od osób o małych możliwościach przetwarzania 
stymulacji, które tej aktywności - w zgodzie ze swoim temperamentem nie wykazywały na wysokim poziomie. W tym przypadku brak zharmonizowania struktury temperamentu okazał się paradoksalnie korzystny.

Można zatem sądzić, że nawet osoby, które wskutek nieefektywnej regulacji poziomu pobudzenia mogą być chronicznie przestymulowane (i być może „cierpi” na tym ich zdolność do samokontroli emocjonalnej), dzięki różnym doświadczeniom, intensywnemu treningowi społecznemu, wchodzeniu w sytuacje zadaniowe, bardziej rozwijają własną inteligencję emocjonalną niż osoby, które cechując się małymi możliwościami przetwarzania stymulacji, funkcjonują „w zgodzie” $\mathrm{z}$ własnym temperamentem. Osoby, które charakteryzuje tendencja do przestymulowywania się, potrafią sprawnie działać w sytuacjach niedostosowanych do ich możliwości przetwarzania stymulacji, ponoszą jednak koszty psychoemocjonalne takiej sytuacji. Z badań przeprowadzonych na potrzeby tej pracy można wnioskować, że nawet jeśli te koszty są wysokie, okazują się „opłacalne” jeśli chodzi o rozwój inteligencji emocjonalnej. W świetle uzyskanych przeze mnie wyników potwierdzenie zyskuje teza o znaczeniu aktywności jako ważnym czynniku rozwoju inteligencji emocjonalnej (por. Matczak, 2003; Przetacznik-Gierowska, 1996). 


\section{PODSUMOWANIE}

Niniejsza monografia jest próbą ukazania inteligencji emocjonalnej w szerokim kontekście, uwzględniającym jej rodzaje, uwarunkowania środowiskowe, związki z płcią i osobowością. Odniesienie inteligencji emocjonalnej do teorii osobowości i dwóch systemów przetwarzania informacji pokazuje, jak różne konstrukty dotyczące funkcjonowania psychicznego człowieka się ze sobą przenikają i nakładają - jak różni badacze, innym językiem mówią, w gruncie rzeczy, o tej samej rzeczywistości.

Przytoczone badania własne nad inteligencją emocjonalną potwierdzają znaczenie temperamentu dla jej rozwoju (sceptyczny Czytelnik mógłby tutaj skomentować, że „temperament jest dobry na wszystko” i absolutnie bym się z nim zgodziła). Są takie kombinacje cech temperamentu, które wydają się być bardziej sprzyjające wysokiej inteligencji emocjonalnej. Mowa tutaj zwłaszcza o takich komponentach temperamentu, które stanowią o wielkości zapotrzebowania na stymulację oraz możliwości jej przetwarzania i przekładają się m.in. na poziom aktywności człowieka. Uzyskane wyniki potwierdzają ważność aktywności dla rozwoju zdolności emocjonalnych, nawet jeśli jest ona podejmowana niejako „wbrew własnemu temperamentowi”. Mowa tutaj o osobach, które, mimo posiadania niskiego zapotrzebowania na stymulację, podejmują dużą aktywność.

W świetle uzyskanych danych okazuje się, że płeć nie jest zmienną różnicującą ogólny poziom inteligencji emocjonalnej, lecz wpływa raczej na posiadany profil zdolności emocjonalnych (intraindywidualne zróżnicowanie zdolności). Kobiety częściej ujawniają przewagę w zakresie doświadczeniowej inteligencji emocjonalnej, zaś mężczyźni częściej górują w zakresie strategicznej inteligencji emocjonalnej. U kobiet wyższe zdolności do empatii oraz do akceptowania, wyrażania i wykorzystywania własnych emocji w działaniu umożliwiają łatwość i sprawność odczytywania emocji innych oraz adekwatną ekspresję emocjonalną. To sprawia, że kobiety są odbierane często jako bardziej emocjonalne niż mężczyźni, bo łatwiej przychodzi im ujawnianie tego, co czują. Wpływa to również na lepsze radzenie sobie z emocjami innych osób. Mężczyźni, którzy lepiej uświadamiają sobie, rozumieją i kontrolują własne emocje, łatwiej też dzięki temu nimi zarządzają. To z kolei może się u nich przekładać na większe poczucie własnej 
skuteczności w obszarze inteligencji emocjonalnej i na przekonanie, że mogą własne emocje doskonalić i modyfikować.

Jako wniosek praktyczny niniejszej pracy można postulować, żeby sposoby oddziaływań wychowawczych indywidualizować w zależności od temperamentu jednostki. Osobom o małych możliwościach przetwarzania stymulacji umiejętnie dostarczać okazji i motywacji do treningu społecznego, z akcentem na rozwój działaniowej inteligencji emocjonalnej, będącej ich słabszą stroną, zaś osobom o dużych możliwościach stymulacji dostarczać treningu ukierunkowanego na pracę nad inteligencją emocjonalną poznawczą, która jest ich słabszą stroną. Doświadczenie terapeutyczne pokazuje, że trening inteligencji emocjonalnej przynosi wymierne efekty nawet u osób z dużymi deficytami w zakresie zdolności emocjonalnych, które do pewnego stopnia mogą podnosić swoją inteligencję emocjonalną, tym samym poprawiając jakość swojego życia.

Wiemy już, jak ważną rolę odgrywa środowisko w kształtowaniu się inteligencji emocjonalnej. Na szczęście nie istnieje tutaj coś takiego jak determinizm. Złe warunki startowe w historii życia danego człowieka mogą obniżyć jego zdolności emocjonalne, ale nie muszą. Istnieje przecież resilience, czyli odporność psychiczna i wiele mechanizmów kompensacyjnych w naszej psychice, które dają nadzieję na wysoką inteligencję emocjonalną tym wszystkim, którzy nie urodzili się w szczęśliwej, „inteligentnej emocjonalnie rodzinie".

Przeczytawszy niniejszą monografię, wszyscy, niezależnie od tego z jaką płcią się identyfikujemy, możemy odetchnąć z ulgą, bo płeć generalnie nie różnicuje poziomu inteligencji emocjonalnej. Nawet jeśli niektóre zdolności emocjonalne okazują się wyższe u którejś z płci, to przecież świadomy odbiorca wie, że mowa o statystycznej kobiecie, czy statystycznym mężczyźnie (a więc o takich, którzy realnie nie istnieją). Każdy z nas jest wyjątkową, niepowtarzalną jednostką, może więc stanowić wyjątek również w tej kwestii.

Odetchnąć może także ten Czytelnik, który rozpoznaje u siebie temperament o dużych możliwościach przetwarzania stymulacji. Niestety, nie pozostawię go w błogim samozadowoleniu, bo taki typ temperamentu - jak okazało się w przeprowadzonych badaniach - owszem, sprzyja wysokiej inteligencji emocjonalnej, nie jest jednak jej gwarantem.

Z kolei Czytelnikowi, który uważa, że przypadł mu w udziale gorszy los, bo posiada temperament o małych możliwościach przetwarzania stymulacji 
- czyli taki, który okazał się mniej korzystny dla inteligencji emocjonalnej na pocieszenie dodam, że zawsze można zdolności emocjonalne trenować i rozwijać.

Inteligencja emocjonalna jest już tzw. „młodym dorosłym” z blisko ponad 30-letnim doświadczeniem życiowym. Czasy pierwszej młodości i zachwytu nad nią należą do przeszłości. Nie utrzymał się „efekt aureoli”, jaki jej początkowo towarzyszył. Wiemy już, że samo posiadanie wysokiej inteligencji emocjonalnej nie czyni nas dobrym i szlachetnym człowiekiem; można być inteligentnym emocjonalnie psychopatą, który dzięki zdolnościom emocjonalnym sprawnie i skutecznie manipuluje otoczeniem. Etap dojrzałości inteligencji emocjonalnej pokazuje zatem, że ma ona swoje zalety, ale nie brak jej też ograniczeń. Czas płynie, a wraz z nim starzeje się sama inteligencja emocjonalna...

Jak dalej potoczą się jej losy? Czy nadal będzie budzić żywe zainteresowanie kolejnych pokoleń badaczy i czytelników? Wydaje się, że choć inteligencja emocjonalna nie jest już może tak „świeża i młoda”, to nadal pozostaje nieco tajemnicza i na tyle atrakcyjna, że na pewno znajdą się tacy, którzy zechcą bliżej ją poznać.

Inteligencja emocjonalna nie rozwiąże wszystkich problemów człowieka i nie zapewni mu szczęścia. Z drugiej strony, jej niski poziom czy deficyty w poszczególnych zdolnościach emocjonalnych mogą być źródłem niepowodzeń społecznych i poczucia bycia nieszczęśliwym. Lepiej zatem być pięknym, młodym, bogatym i... oczywiście inteligentnym emocjonalnie czego sobie i Tobie, Drogi Czytelniku, z całego serca życzę. 


\section{BIBLIOGRAFIA}

Ahmad, S., Bangash, H., Ahmad Khan, S. (2009). Emotional intelligence and gender differences. Sarhad Journal of Agriculture, 25(1), 127-130.

Akiskal, H. S., Akiskal, K. K. (2005). TEMPS: Temperament Evaluation of Memphis, Pisa, Paris and San Diego. Journal of Affective Disorders, 85(1-2), $1-242$.

Ammaniti, M. (2008). Quanto pesa una emozione. La Repubblica, 8.08.2008, $52-53$.

Andi, H. K. (2012). Emotional intelligence and personality traits: A correlational study of MYEIT and BFI. International Journal of Academic Research in Business and Social Science, 2(10), 285-295.

Argyle, M. (1988). Bodily communication. Londres: Methuen.

Argyle, M. (1991). Cooperation: The basis of sociability. Londres: Routledge.

Argyle, M. (1999). Psychologia stosunków międzyludzkich. Warszawa: Wydawnictwo Naukowe PWN.

Aronson, E., Wilson, T. D., Akert, R. M. (1997). Psychologia społeczna - serce i umyst. Poznań: Wydawnictwo Zysk i S-ka.

Ashton, M. C., Lee, K., Paunonen, S. V. (2002). What is the central feature of extraversion? Social attention versus reward sensitivity. Journal of Personality and Social Psychology, 83(1), 245-252. https://doi.org/10.1037/00223514.83.1.245

Austin, E. J. (2005). Emotional intelligence and emotional information processing. Personality and Individual Differences, 39(2), 403-413. https://doi. org/10.1016/j.paid.2005.01.017

Austin, E. J., Evans, P., Goldwater, R., Potter, V. (2005). A preliminary study of emotional intelligence, empathy and exam performance in first year medical students. Personality and Individual Differences, 39(8), 1395-1405. https:// doi.org/10.1016/j.paid.2005.04.014

Austin, E. J., Saklofske, D. H., Egan, V. (2005). Personality, well-being and health correlates of trait emotional intelligence. Personality and Individual Differences, 38(3), 547-558. https://doi.org/10.1016/j.paid.2004.05.009

Barchard, K. A. (2003). Does emotional intelligence assist in the prediction of academic success? Educational and Psychological Measurement, 63(5), 840-858. https://doi.org/10.1177/0013164403251333 
Bar-On, R. (1997). EQ-i. BarOn Emotional Quotient Inventory. A measure of emotional intelligence. User's manual. Toronto: Multi-Health Systems.

Bar-On, R. (2000). Emotional and social intelligence: Insights from the Emotional Quotient Inventory. W: R. Bar-On, J. D. A. Parker (red.), The handbook of emotional intelligence (s. 363-388). San Francisco: Jossey-Bass Inc., A Wiley Company.

Bar-On, R. (2001). Emotional intelligence and self-actualization. W: J. Ciarrochi, J. P. Forgas, J. D. Mayer (red.), Emotional intelligence in everyday life (s. 82-97). Philadelphia: Psychology Press.

Bar-On, R. (2002). Bar-On Emotional Quotient Inventory (EQ-I): Technical Manual. Toronto: Multi-Health Systems.

Bartosz, B. (red.). (2011). Kobiecość i męskość: komunikacja, relacje, społeczeństwo. Warszawa: ENETEIA Wydawnictwo Psychologii i Kultury.

Bastian, V. A., Burns, N. R., Nettelbeck, T. (2005). Emotional intelligence predicts life skills, but not as well as personality and cognitive abilities. Personality and Individual Differences, 39(6), 1135-1145. https://doi.org/10.1016/j. paid.2005.04.006

Beatty, M. J., McCroskey, J. C., Heisel, A. D. (1998). Communication apprehension as temperamental expression: A communibiological paradigm. Communication Monographs, 65(3), 197-219. https://doi.org/ $10.1080 / 03637759809376448$

Bem, S. L. (2000). Męskość kobiecość. O różnicach wynikających z płci. Gdańsk: GWP.

Besharat, M. A. (2007). Psychometric properties of Farsi version of the Emotional Intelligence Scale-41 (FEIS-41). Personality and Individual Differences, 43(5), 991-1000. https://doi.org/10.1016/j.paid.2007.02.020

Białopiotrowicz, G. (2005). Kobieta-mężczyzna: psychologiczne gry w miłości $i$ biznesie. Warszawa: Poltext.

Bindu, P., Thomas, I. (2006). Gender differences in emotional intelligence. Psychological Studies, 51(4), 261-268.

Borecka-Biernat, D. (1995). Nieśmiałość i agresja nastolatków a styl wychowania w rodzinie. Problemy rodziny, 5, 45-46.

Bowen, M. (1978). Family therapy in clinical practice. Nowy Jork: Jason Aronson. Bowlby, J. (2007). Przywiazanie. Warszawa: Wydawnictwo Naukowe PWN. 
Boyatzis, R. E. (2009). A behavioral approach to emotional intelligence. Journal of Management Development, 28(9), 749-770. https://doi.org/10.1108/02621710910987647

Boyatzis, R. E., Goleman, D. (2007). Emotional Competency Inventory. Boston: The Hay Group.

Brackett, M. A., Mayer, J. D. (2003). Convergent, discriminant, and incremental validity of competing measures of emotional intelligence. Personality and Social Psychology Bulletin, 29(9), 1-12. https://doi. org/10.1177/0146167203254596

Bracket, M. A., Mayer, J. D., Warner, R. M. (2004). Emotional intelligence and its relations to everyday behaviour. W: P. Salovey, M. A. Brackett, J. D. Mayer (red.), Emotional intelligence: Key readings on the Mayer and Salovey model (s. 223-241). Port Chester: Dude Publishing. https://doi.org/10.1016/S01918869(03)00236-8

Brackett, M. A., Salovey, P. (2008). Pomiar inteligencji emocjonalnej skalą Mayer-Salovey-Caruso Emotional Intelligence Test. W: M. Śmieja, J. Orzechowski (red.), Inteligencja emocjonalna. Fakty, mity, kontrowersje (s. 113-135). Warszawa: Wydawnictwo Naukowe PAN.

Brannon, L. (2002). Psychologia rodzaju. Perspektywa biologiczna i społeczna. Gdańsk: GWP.

Braun-Gałkowska, M. (1985). Miłość aktywna. Warszawa: Instytut Wydawniczy PAX.

Braun-Gałkowska, M. (1992). Psychologiczna analiza systemów rodzinnych osób zadowolonych i niezadowolonych $z$ małżeństwa. Lublin: Towarzystwo Naukowe KUL.

Brody, R. L. (1985). Gender differences in emotional development: A review of theories and research. W: A. J. Stewart, M. Brinton Lykes (red.), Gender and personality: Current perspectives on theory and research (s. 14-61). Durham: Duke University Press. https://doi.org/10.1111/j.1467-6494.1985.tb00361.x Brody, R. L., Hall, J. A. (2005). Płeć, emocje i ekspresja. W: M. Lewis, J. M. Haviland-Jones (red.), Psychologia emocji (s. 431-445). Gdańsk: GWP.

Budohoska, W., Grabowska, A. (1994). Dwie pótkule - jeden mózg. Warszawa: WP. 
Campbell, J. M., McCord, D. M. (1996). The WAIS-R Comprehension and Picture Arrangement subtests as measures of social intelligence: Testing traditional interpretations. Journal of Psychoeducational Assessment, 14(3), 240-249. https://doi.org/10.1177/073428299601400305

Cattell, R. B. (1971). Abilities: Their structure, growth, and action. Boston: Houghton Millfin.

Cervantes, C. A., Callanan, M. A. (1998). Labels and explanations in mother-child emotion talk: Age and gender differentiation. Developmental Psychology, 34(1), 88-98. https://doi.org/10.1037/0012-1649.34.1.88

Chan, D. W. (2004). Perceived emotional differences and self-efficacy among Chinese secondary school teachers in Hong Kong. Personality and Individual Differences, 36(8), 1781-1795. https://doi.org/10.1016/j.paid.2003.07.007

Chaplin, T. M., Cole, P. M., Zahn-Waxler, C. (2005). Parental socialization of emotion expression: Gender differences and relations to child adjustment. Emotion, 5(1), 80-88. https://doi.org/10.1037/1528-3542.5.1.80

Charbonneau, D., Nicol, A. A. M. (2002). Emotional intelligence and leadership in adolescents. Personality and Individual Differences, 33(7), 1101-1113. https://doi.org/10.1016/S0191-8869(01)00216-1

Christophel, D. M. (1990). The relationship among teacher immediacy behaviors, student motivation and learning. Communication Education, 37, 323-340. https://doi.org/10.1080/03634529009378813

Ciarrochi, J. V., Chan, A. Y. C., Bajgar, J. (2001). Measuring emotional intelligence in adolescents. Personality and Individual Differences, 31(7), 1105-1119.

Ciarrochi, J. V., Chan, A. Y. C., Caputi, P. (2000). A critical evaluation of the emotional intelligence construct. Personality and Individual Differences, 28(3), 539-561. https://doi.org/10.1016/S0191-8869(99)00119-1

Ciarrochi, J. V., Chan, A. Y. C., Caputi, P., Roberts, R. (2001). Measuring emotional intelligence. W: J. Ciarrochi, P. Forgas, J. D. Mayer (red.), Emotional intelligence in everyday life (s. 25-45). Filadelfia: Psychology Press, Taylor \& Francis Group.

Ciarrochi, J. V., Deane, F. P., Anderson, S. (2002). Emotional intelligence moderates the relationship between stress and mental health. Personality and Individual Differences, 32, 197-209. http://doi.org/10.1016/S01918869(01)00012-5 
Cooper, R. K., Sawaf, A. (2000). EQ. Inteligencja emocjonalna $w$ organizacji i zarządzaniu. Warszawa: Studio Emka.

Crabb, L. (1994). Mężczyźni i kobiety: O tym, jak się cieszyć tym co nas różni. Warszawa: Wydawnictwo Rodzinny Krąg.

Damasio, A. (1999). Błąd Kartezjusza: emocje, rozum i ludzki mózg. Poznań: Dom Wydawniczy Rebis.

Davies, P., Cummings, E. M. (1994). Marital conflict and child adjustment: An emotional security hypothesis. Psychological Bulletin, 116(3), 387-411. https://doi.org/10.1037/0033-2909.116.3.387

Davies, M., Stankov, L., Roberts, R. (1998). Emotional intelligence: In search of an elusive construct. Journal of Personality and Social Psychology, 75(4), 989-1015. https://doi.org/10.1037/0022-3514.75.4.989

Dawda, D., Hart, S. D. (2000). Assessing emotional intelligence: Reliability and validity of the Bar-On Emotional Quotient Inventory (EQ-i) in university students. Personality and Individual Differences, 28(4), 797-812. https://doi. org/10.1016/S0191-8869(99)00139-7

Day, A. L., Carroll, S. A. (2004). Using an ability-based measure of emotional intelligence to predict individual performance, group performance and group citizenship behaviours. Personality and Individual Differences, 36(6), 1443-1458. https://doi.org/10.1016/S0191-8869(03)00240-X

Dembińska-Krajewska, D., Rybakowski, J. (2014). Skala TEMPS-A (Temperament Evaluation of Memphis, Pisa and San Diego Autoquestionnaire) - ważne narzędzie do badania temperamentów afektywnych. Psychiatria Polska, 48(2), 261-276.

Denes-Raj, V., Epstein, S. (1994). Conflict between experiential and rational processing: When people behave against their better judgment. Journal of Personality and Social Psychology, 66(5), 819-829. https://doi. org/10.1037/0022-3514.66.5.819

Denham, S. A. (1998). Emotional development in young children. Nowy Jork, Londyn: The Guilford Press.

Denham, S. A., Auerbach, S. (1995). Mother-child dialogue about preschoolers' emotions and preschoolers' emotional competence. Genetic, Social \& General Psychology Monographs, 121(3), 313-338. 
Denham, S. A., Blair, K., DeMulder, E., Levitas, J., Sawyer, K., Auerbach-Major, S., Queenan, P. (2003). Preschool emotional intelligence: Pathway to social competence? Child Development, 74, 238-256. https://doi.org/10.1111/14678624.00533

Denham, S. A., Renwick, S. M., Holt, R. W. (1991). Working and playing together: Prediction of preschool social-emotional competence from mother-child interaction. Child Development, 62(2), 242-249. https://doi. org $/ 10.2307 / 1131000$

De Raad, B. (2005). The trait-coverage of emotional intelligence. Personality and Individual Differences, 38(3), 673-687. https://doi.org/10.1016/j. paid.2004.05.022

Di, M., Deng, X., Zhao, J., Kong, F. (2020). Psychometric properties and measurement invariance across sex of the Wong and Law Emotional Intelligence Scale in Chinese adolescents. Psychological Reports. Advanced online publication. https://doi.org/10.1177/0033294120972634

Di, M., Jia, N., Wang, Q., Yan, W., Yang, K., Kong, F. (2020). A bifactor model of the Wong and Law Emotional Intelligence Scale and its association with subjective well-being. The Journal of Positive Psychology, Advanced online publication. https://doi.org/10.1080/17439760.2020.1791947

Di Fabio, A., Kenny M. E. (2016). Promoting well-being: The contribution of emotional intelligence. Frontiers in Psychology, 7, 11-82. https://doi. org/10.3389/fpsyg.2016.01182

Di Fabio, A., Palazzeschi, L., Bucci, O., Guazzini, A., Burgassi, Ch., Pesce, E. (2018). Personality traits and positive resources of workers for sustainable development: Is emotional intelligence a mediator for optimism and hope? Sustainability, 10(10), 1-14. https://doi.org/10.3390/su10103422

Dobrołowicz, W. (1995). Myśleć intuicyjnie. Warszawa: Wydawnictwa Naukowo-Techniczne, Fundacja Książka Naukowo-Techniczna.

Dobrołowicz, W. (2001). Inteligencja intuicyjna. Annales Universitatis Mariae Curie-Skłodowska, Lublin-Polonia, Sectio J, 14, 267-280.

Dobrołowicz, W. (2002). W stronę treningu inteligencji intuicyjnej. W: W. Dobrołowicz, M. Karwowski (red.), W stronę kreatywności. Warszawa: Wydawnictwo Akademii Pedagogiki Specjalnej im. Marii Grzegorzewskiej. Dolata, E. (2001). Psychologia rozpoznawania twarzy i ich ekspresji. Białystok: Trans Humana. 
Doliński, D. (2002a). Mechanizmy wzbudzania emocji. W: J. Strelau (red.), Psychologia. Podręcznik akademicki (t. 2, s. 319-349). Gdańsk: GWP.

Doliński, D. (2002b). Emocje, poznanie i zachowanie. W: J. Strelau (red.), Psychologia. Podręcznik akademicki (t. 2, s. 369-394). Gdańsk: GWP.

Doliński, D. (2002c). Ekspresja emocji. Emocje podstawowe i pochodne. W: J. Strelau (red.), Psychologia. Podręcznik akademicki (t. 2, s. 350-368). Gdańsk: GWP.

Dudek, Z. (2002). Intuicja w systemie osobowości. Albo Albo. Problemy Psychologii i Kultury, 4, 45-63.

Eisenberg, N., Fabes, R. A., Losoya, S. (1999). Reakcje emocjonalne: ich regulacja, korelaty społeczne i socjalizacja. W: P. Salovey, D. J. Sluyter (red.), Rozwój emocjonalny a inteligencja emocjonalna: problemy edukacyjne (s. 223-280). Poznań: Dom Wydawniczy Rebis.

Eisenberg, N., Fabes, R. A., Murphy, B. C., Shepard, S., Guthrie, I. K., Mazsk, P., Poulin, R., Jones, S. (1999). Prediction of elementary school children's socially appropriate and problem behavior from anger reactions at age 4-6 years. Journal of Applied Developmental Psychology, 20(1), 119-142. https:// doi.org/10.1016/S0193-3973(99)80007-0

Eisenberg, N., Valiente, C., Champion, C. (2008). Reakcje pokrewne empatii. Korelaty moralne, społeczne i socjalizacyjne. W: A. Miller (red.), Dobro i zło z perspektywy psychologii społecznej (s. 480-516). Kraków: Wydawnictwo WAM.

Ekman, P., Levenson, R. W., Friesen, W. V. (1983). Autonomic nervous system activity distinguishes among emotions. Science, 221(4616), 1208-1210. https://doi.org/10.1126/science.6612338

Elfenbein, H. A., Ambady, N. (2002). On the universality and cultural specificity of emotion recognition: A meta-analysis. Psychological Bulletin, 128(2), 203-235. https://doi.org/10.1037/0033-2909.128.2.203

Eliasz, A. (1974). Temperament a osobowość. Wrocław, Warszawa, Kraków: Zakład Narodowy im. Ossolińskich, Wydawnictwo PAN.

Eliasz, A. (1981). Temperament a system regulacji stymulacji. Warszawa: Państwowe Wydawnictwo Naukowe.

Eliasz, A. (1992). Rola interakcji temperamentu i środowiska w rozwoju człowieka. W: A. Eliasz, M. Marszał-Wiśniewska (red.), Temperament a rozwój młodzieży (s. 11-27). Warszawa: Instytut Psychologii PAN. 
Eliasz, A., Cofta, L. (1992). Temperament a skłonność do chorób. W: J. Strelau, W. Ciarkowska, E. Nęcka (red.), Różnice indywidualne: możliwości i preferencje (s. 65-80). Wrocław: Ossolineum.

Epstein, S. (1994). Integration of the cognitive and the psychodynamic unconscious. American Psychologist, 49(8), 709-724. https://doi.org/10.1037/0003066X.49.8.709

Epstein, S. (2003). Cognitive-experiential self-theory of personality. W: T. Millon, M. J. Lerner (red.), Comprehensive handbook of psychology, t. 5: Personality and social psychology (s. 159-184). Hoboken: Viley \& Sons.

Epstein, S. (2008). Intuition from perspective of cognitive-experiential self-theory. W: H. Plessner, C. Betsch, T. Betsch (red.), Intuition in judgment and decision making (s. 23-37). Nowy Jork: Lawrence Erlbaum Associates.

Epstein, S. (2014). Cognitive-experiential theory: An integrative theory of personality. Nowy Jork: Oxford University Press. https://doi.org/10.1093/ acprof:osobl/9780199927555.001.0001

Epstein, S., Lipson, A., Holstein, C., Huh, E. (1992). Irrational reactions to negative outcomes: evidence for two conceptual systems. Journal and Personality and Social Psychology, 62(2), 328-339. https://doi.org/10.1037/00223514.62.2.328

Epstein, S., Pacini, R., Denes-Raj, V., Heier, H. (1996). Individual differences in intuitive-experiential and analytical-rational thinking styles. Journal of Personality and Social Psychology, 71(2), 390-405. https://doi. org/10.1037/0022-3514.71.2.390

Evans, J. St. B. T. (2008). Dual-processing accounts of reasoning, judgment, and social cognition. Annual Review of Psychology, 59, 255-278.

Evans, J. St. B. T. (2010). Thinking twice: Two minds in one brain. Nowy Jork: Oxford University Press.

Evans, J. St. B. T., Stanovich, K. E. (2013a). Dual-process theories of higher cognition: Advancing the debate. Perspectives on Psychological Science, 8(3), 223-241. https://doi.org/10.1177/1745691612460685

Evans, J. St. B. T., Stanovich, K. E. (2013b). Theory and metatheory in the study of dual processes: Reply to comments. Perspectives on Psychological Science, 8(3), 263-271. https://doi.org/10.1177/1745691613483774

Extremera, N. (2019). Validation of the Spanish version of the Wong Law Emotional Intelligence Scale (WLEIS-S). Psicothema, 31(1), 94-100. https://doi. org/10.7334/psicothema2018.147 
Eysenck, H. J. (1970). The structure of human personality. Londyn: Methuen. Eysenck, H. J., Eysenck, M. W. (1985). Personality and individual differences: A natural science approach. Nowy Jork: Plenum Press.

Fabes, R. A., Martin, C. L. (1991). Gender and age stereotypes of emotionality. Personality and Social Psychology Bulletin. 17(5), 532-540. https://doi. org/10.1177/0146167291175008

Farrelly, D., Austin, E. J. (2007). Ability EI as an intelligence? Associations of the MSCEIT with performance on emotion processing and social tasks and with cognitive ability. Cognition and Emotion, 21(5), 1043-1063. https://doi. org/10.1080/02699930601069404

Feldman Barrett, L. (1997). The relationship among momentary emotion experiences, personality descriptions and retrospective rating of emotion. Personality and Social Psychology Bulletin, 23(10), 1100-1110. https://doi. org/10.1177\%2F01461672972310010

Ferguson, G. A., Takane, Y. (2002). Analiza statystyczna w psychologii i pedagogice. Warszawa: Wydawnictwo Naukowe PWN.

Field, D. (1996). Osobowości rodzinne. Warszawa: Oficyna Wydawnicza „Logos”.

Fiori, M., Antonakis, J. (2011). The ability model of emotional intelligence: Searching for valid measures. Personality and Individual Differences, 50(3), 329-334. https://doi.org/10.1016/j.paid.2010.10.010

Fiori, M., Shagini, U., Vesely-Maillefer, A. (2019). Introducing a new component of emotional intelligence: Emotion information processing. Academy of Management Proceedings, 1,17276. https://doi.org/17276.10.5465/ AMBPP.2019.17276abstract

Firkowska-Mankiewicz, A. (1993). Spór o inteligencję człowieka: dziedziczność czy środowisko? Warszawa: PAN.

Fischer, A. H. (red.). (2000). Gender and emotion: Social psychological perspectives. Nowy Jork: Cambridge University Press. https://doi.org/10.1017/ CBO9780511628191

Fivush, R., Brotman, M. A., Buckner, J. P., Goodman, S. H. (2000). Gender differences in parent-child emotion narratives. Sex Roles: A Journal of Research, 42(3-4), 233-253. https://doi.org/10.1023/A:1007091207068

Francis, L. J. (1993). The dual nature of the Eysenckian neuroticism scale: A question of sex differences? Personality and Individual Differences, 15(1), 43-59. https://doi.org/10.1016/0191-8869(93)90040-A

Freud, S. (1994). Poza zasada przyjemności. Warszawa: PWN. 
Freud, A. (1997). Ego i mechanizmy obronne. Warszawa: PWN.

Frielingsdorf, K. (1997). Demoniczne obrazy Boga. Kraków: Wydawnictwo WAM.

Frost, W., Averill, R. J. (1982). Differences between men and women in the everyday experience of anger. W: R. J. Averill (red.), Anger and aggression: An essay on emotion (s. 281-316). Nowy Jork: Springer-Verlag.

Fujita, F., Diener, E., Sandvik, E. (1991). Gender differences in negative affect and well-being: The case for emotional intensity. Journal of Personality and Social Psychology, 61(3), 427-434. https://doi.org/10.1037/00223514.61.3.427

Garcia-Sancho, E., Salguero, J. M., Fernandez-Berrocal, P. (2016). Angry rumination as a mediator of the relationship between ability emotional intelligence and various types of aggression. Personality and Individual Differences, 89, 143-147. https://doi.org/10.1016/j.paid.2015.10.007

Gardner, H. (1983). Frames of mind: the theory of multiple intelligences. Nowy Jork: Basic Books.

Gardner, H., Kornhaber, M. L., Wake, W. K. (2001). Inteligencja: Wielorakie perspektywy. Warszawa: Wydawnictwa Szkolne i Pedagogiczne.

Gasiul, H. (2002). Teorie emocji i motywacji. Warszawa: Wydawnictwo UKSW. Gannon, N., Ranzijn, R. (2005). Does emotional intelligence predict unique variance in life satisfaction beyond IQ and personality? Personality and Individual Differences, 38(6), 1353-1364. https://doi.org/10.1016/j. paid.2004.09.001

Gil-Olarte Marquez, P., Palomera Martin, R., Brackett, M. A. (2006). Relating emotional intelligence to social competences and academic achievement among high school students. Psicothema, 18, 118-123.

Gohm, C. L., Corser, G. C., Dalsky, D. J. (2005). Emotional intelligence under stress: Useful, unnecessary, or irrelevant? Personality and Individual Differences, 39(6), 1017-1028. https://doi.org/10.1016/j.paid.2005.03.018

Goleman, D. (1995). Emotional intelligence. Nowy Jork: Bantam; wyd. polskie: D. Goleman (1997). Inteligencja emocjonalna. Poznań: Media Rodzina.

Goleman, D. (1999). Inteligencja emocjonalna w praktyce. Poznań: Media Rodzina.

Goleman, D., Boyatzis, R., McKee, A. (2002). Naturalne przywództwo: Odkrywanie mocy inteligencji emocjonalnej. Wrocław, Warszawa: Jacek Santorski, Wydawnictwa Biznesowe. 
Golińska, L. (1993). Temperamentalne uwarunkowania percepcji społecznej. Łódź: Wydawnictwo Uniwersytetu Łódzkiego.

Goodman, S. H., Brogan, D., Lynch, M. E., Fielding, B. (1993). Social and emotional competence in children of depressed mothers. Child Development, 64(2), 516-531. https://doi.org/10.2307/1131266

Gray, J. (2011). Goraca Wenus, zimny Mars: Znaczenie równowagi hormonalnej dla miłości, poziomu energii i jakości życia. Poznań: Dom Wydawniczy Rebis.

Greenspan, S. I., Benderly, B. L. (2000). Rozwój umystu: Emocjonalne podstawy inteligencji. Poznań: Dom Wydawniczy Rebis.

Grolnick, W. S., Ryan, R. M. (1989). Parent styles associated with children's self-regulation and competence in school. Journal of Educational Psychology, 81(2), 143-154. https://doi.org/10.1037/0022-0663.81.2.143

Grossmann, M., Wood, W. (1993). Sex differences in intensity of emotional experience: A social role interpretation. Journal of Personality and Social Psychology, 65(5), 1010-1022. https://doi.org/10.1037/0022-3514.65.5.1010

Guastello, D. D., Guastello, S. J. (2003). Androgyny, gender role behavior and emotional intelligence among college students and their parents. Sex Roles: A Journal of Research, 23, 217-227.

Gur, R. C., Gunning-Dixon, F., Bilker, W. B., Gur, R. E. (2002). Sex diffrences in temporo-limbic and frontal brain volumes of healthy adults. Cerebral Cortex, 12, 998-1003. https://doi.org/10.1093/cercor/12.9.998

Hair, J. F., Anderson, R. E., Babin, B. J., Black, W. C. (2009). Canonical correlation. A supplement to Multivariate Data Analysis. Pobrane z: http://www. mvstats.com/Downloads/Supplements/Canonical_Correlation_7e.pdf

Halberstadt, A. G., Denham, S. A., Dunsmore, J. C. (2001). Affective social competence. Social Development, 10(1), 79-119. https://doi.org/10.1111/14679507.00150

Halberstadt, A. G., Hall, J. A. (1980). Who's getting the message? Children's nonverbal skill and their evaluation by teachers. Development Psychology, 16(6), 564-573. https://doi.org/10.1037/0012-1649.16.6.564

Hall, J. A., Matsumoto, D. (2004). Gender differences in judgments of multiple emotions from facial expressions. Emotion, 4(2), 201-206. https://doi. org/10.1037/1528-3542.4.2.201 
Hayes, N., Joseph, S. (2003). Big 5 correlates of three measures of subjective well-being. Personality and Individual Differences, 34(4), 723-727. https:// doi.org/10.1016/S0191-8869(02)00057-0

Heesacker, M., Wester, S. R., Vogel, D. L., Wentzel, J. T., Mejia-Millan, C. M., Goodholm, Jr., Carl, R. (1999). Gender-based emotional stereotyping. Journal of Counseling Psychology, 46(4), 483-495. https://doi.org/10.1037/00220167.46.4.483

Hemmati, T., Mills, J. F., Kroner, D. G. (2004). The validity of the Bar-On Emotional Intelligence Quotient in an offender population. Personality and Individual Differences, 37(4), 695-706. https://doi.org/10.1016/j. paid.2003.10.003

Horney, K. (2012). Psychologia kobiety. Poznań: Dom Wydawniczy Rebis.

Izard, C. E. (2001). Emotional intelligence or adaptive emotions? Emotion, 1(3), 249-257. https://doi.org/10.1037/1528-3542.1.3.249

Jakubik, A. (2002). Kontrowersje wokół osobowości pogranicznej. W: K. Maurin, A. Motycka (red.), Fenomen Junga. Dzieło. Inspiracje. Współczesność (s. 134-141). Warszawa: Eneteia.

Jasielska, A. (2001). Interpretacja komunikatów symbolicznych przez aleksytymików i niealeksytymików. Przegląd Psychologiczny, 44(2), 209-220.

Jasielska, A. (2007). Zastosowanie analizy transkrypcji do pomiaru inteligencji emocjonalnej. Psychologia, Edukacja i Społeczeństwo, 4(1), 29-45.

Jasielska, A., Leopold, M. A. (2000). Kompetencja a inteligencja emocjonalna - pojęcia tożsame czy różne? Forum Oświatowe, 2(23), 5-32.

Jaušovec, N., Jaušovec, K. (2005). Sex differences in brain activity related to general and emotional intelligence. Brain and Cognition, 59, 277-286. https:// doi.org/10.1016/j.bandc.2005.08.001

Jaworowska, A., Matczak, A. (2001). Kwestionariusz inteligencji emocjonalnej. Warszawa: Pracownia Testów Psychologicznych PTP.

Jaworowska, A., Matczak, A. (2005). Popularny kwestionariusz inteligencji emocjonalnej PKIE. Podręcznik. Warszawa: Pracownia Testów Psychologicznych PTP.

Jaworowska, A., Matczak, A. (2008). Kwestionariusz inteligencji emocjonalnej INTE. Podręcznik. Warszawa: Pracownia Testów Psychologicznych PTP. Jonason, P., Webster, G. (2010). The dirty dozen: A concise measure of the Dark Triad. Psychological Assessment, 22(2), 420-432. https://doi.org/10.1037/ a0019265 
Kafetsios, K. (2004). Attachment and emotional intelligence abilities across the life course. Personality and Individual Differences, 37(1), 129-145. https:// doi.org/10.1016/j.paid.2003.08.006

Karwowski, M. (2006). Intuicja jako zdolność, wymiar osobowości i styl funkcjonowania. Syntetyzujący przegląd niektórych stanowisk psychologicznych. Studia Psychologica UKSW, 6, 189-206.

Kimura, D. (2006). Płeć i poznanie. Warszawa: Polski Instytut Wydawniczy.

Kirkpatrick, L. A., Epstein, S. (1992). Cognitive-experiential self-theory of subjective probability: Further evidence fot two conceptual systems. Journal of Personality and Social Psychology, 63(4), 534-544. https://doi. org/10.1037/0022-3514.63.4.534

Kliś, M., Kossewska, J. (1994). Empatia a inteligencja, cechy osobowości i temperament. Psychologia Wychowawcza, 37, 385-394.

Klonowicz, T., Cieślak, R. (2004). Neurotyczność i radzenie sobie ze stresem w sytuacji zagrożenia. W: J. Strelau (red.), Osobowość a stres ekstremalny (s. 281-298). Gdańsk: GWP.

Knopp, K. (2005). Środowisko rodzinne a poziom inteligencji emocjonalnej (Niepublikowana praca doktorska). Uniwersytet Kardynała Stefana Wyszyńskiego. Warszawa.

Knopp, K. (2006). Rola inteligencji emocjonalnej w życiu człowieka. Studia Psychologica UKSW, 6, 221-236.

Knopp, K. (2007). Inteligencja emocjonalna a temperament studentów oraz postawy rodzicielskie ich matek i ojców. Roczniki Psychologiczne, 10(2), $113-134$.

Knopp, K. (2019). Czy sam „rozum” wystarczy? Czyli o znaczeniu inteligencji akademickiej i inteligencji emocjonalnej w funkcjonowaniu dzieci oraz młodzieży. Kwartalnik Naukowy Fides et Ratio, 40(4), 266-280. https://doi. org/10.34766/fetr.v40i4.185

Knopp, K. (2020). Inteligencja emocjonalna dzieci i młodzieży a ich funkcjonowanie w relacjach z rówieśnikami. Kwartalnik Naukowy Fides et Ratio, 44(4),149-163. https://doi.org/10.34766/fetr.v44i4.442

Kolańczyk, A. (1997). O współzmienności emocji i poznania. Przeglad Psychologiczny, 40, 57-79.

Kolańczyk, A. (1999). Czuję, myślę, jestem. Świadomość i procesy psychiczne w ujęciu poznawczym. Gdańsk: GWP. 
Kolańczyk, A., Świerzyński, R. (1995). Emocjonalne wyznaczniki stylu i plastyczności myślenia. Przegląd Psychologiczny, 3/4, 279-304.

Korol, E. (2017). Wzorce funkcjonowania rodziny pochodzenia a inteligencja emocjonalna młodych dorosłych. Studia Psychologica, 15 (1), 19-32. https:// doi.org/10.21697/sp.2015.15.01.02

Kring, A. M. (2000). Gender and anger. W: A. H. Fischer (red.), Gender and emotion: Social psychological perspectives (s. 211-232). Nowy Jork: Cambridge University Press. https://doi.org/10.1017/CBO9780511628191.011

Kring, A. M., Gordon, A. H. (1998). Sex differences in emotion: Expression experience and physiology. Journal of Personality and Social Psychology, 74(3), 686-703. https://doi.org/10.1037/0022-3514.74.3.686

Lane, R. D., Schwartz, G. (1987). Levels of emotional awareness: A cognitive-developmental theory and its application to psychopathology. American Journal of Psychiatry, 54, 309-313. https://ajp.psychiatryonline.org/doi/ abs/10.1176/ajp.144.2.133

Lazarus, R. S. (1984). On the primacy of cognition. American Psychologist, 39(2), 124-129. https://doi.org/10.1037/0003-066X.39.2.124

Le Doux, J. (2000). Mózg emocjonalny. Poznań: Media Rodzina.

Leary, M., Kowalski, R. M. (2001). Lęk społeczny. Gdańsk: GWP.

Ledzińska, M. (1999). Elementy poznawcze i metapoznawcze w inteligencji - od inteligencji poznawczej do emocjonalnej. Psychologia Wychowawcza, $17,1-10$.

Ledzińska, M. (2001). Od inteligencji poznawczej do emocjonalnej. W: B. Kaczmarek, K. Markiewicz, S. Orzechowski (red.), Nowe wyzwania w rozwoju człowieka (s. 27-42). Lublin: Wydawnictwo UMCS.

Leopold, M. A. (2001). Rozumienie pojęcia kompetencja społeczna. Forum Psychologiczne, 1, 155-182.

Leopold, M. A. (2006). Elementy składowe kompetencji emocjonalnej. Czasopismo Psychologiczne, 2, 191-204.

Levassort, O. (1985). Felicità d'amare. Educazione psicologica e sessuale al matrimonio. Rzym: Citta Nuova Editrice.

Lopes, P. N., Salovey, P., Côte, S., Beers, M., Petty, R. E. (red.). (2005). Emotion regulation abilities and the quality of social interaction. Emotion, 5(1), 113-118. https://doi.org/10.1037/1528-3542.5.1.113 
Lopes, P. N., Salovey, P., Straus, R. (2003). Emotional intelligence, personality, and the perceived quality of social relationships. Personality and Individual Differences, 35(3), 641-658. https://doi.org/10.1016/S0191-8869(02)00242-8 Lynn, M., Steel, P. (2006). National differences in subjective well-being: The interactive effects of extraversion and neuroticism. Journal of Happiness Studies, 7, 155-165. https://doi.org/10.1007/s10902-005-1917-z

Lyusin, D. B. (2006). Emotional intelligence as a mixed construct. Journal of Russian and East European Psychology, 44(6), 54-68. https://doi. org/10.2753/RPO1061-0405440604

Łodygowska, E., Chęć, M. (2020). Związki między inteligencją emocjonalną a retrospektywną oceną postaw rodzicielskich. Educational Psychology, 59(17), 51-64. https://doi.org/10.5604/01.3001.0014.2649

Marchwicki, P. (2006). Teoria przywiązania J. Bowlby’ego. Seminare, 23, 365-383.

Marszał-Wiśniewska, M. (1999). Siła woli a temperament. Warszawa: Wydawnictwo Instytutu Psychologii PAN.

Martowska, K. (2007). Cechy środowiska rodzinnego a inteligencja emocjonalna u dzieci. Studia Psychologica, 7, 181-194.

Martowska, K. (2011). Psychologiczne uwarunkowania kompetencji społecznych (Niepublikowana praca doktorska). Uniwersytet Warszawski. Warszawa.

Maruszewski, T., Ścigała, E. (1997). Aleksytymia, procesy emocjonalne a kodowanie informacji. Kolokwia Psychologiczne, 6, 97-123.

Maruszewski, T., Ścigała, E. (1998). Emocje - aleksytymia - poznanie. Poznań: Wydawnictwo Fundacji Humaniora.

Matczak, A. (1987). Intraindywidualne zróżnicowanie zdolności. Psychologia Wychowawcza, 30, 1-11.

Matczak, A. (1994). Diagnoza intelektu. Warszawa: Instytut Psychologii PAN.

Matczak, A. (2001a). Różne oblicza inteligencji: funkcjonowanie intelektu a osobowość. Studia Psychologica UKSW, 2, 157-174.

Matczak, A. (2001b). Temperament a kompetencje społeczne. W: W. Ciarkowska, A. Matczak (red.), Różnice indywidualne: wybrane badania inspirowane Regulacyjna Teoria Temperamentu Profesora Jana Strelaua (s. 53-69). Warszawa: Interdyscyplinarne Centrum Genetyki Zachowania UW.

Matczak, A. (2002). Różnice indywidualne w rozwoju psychicznym. W: B. Harwas-Napierała, J. Trempała (red.), Psychologia rozwoju człowieka, t. 3 (s. 178-206). Warszawa: Wydawnictwo Naukowe PWN. 
Matczak, A. (2003). Zarys psychologii rozwoju. Podręcznik dla nauczycieli. Warszawa: Wydawnictwo Akademickie „Żak”.

Matczak, A. (2004a). Temperament a inteligencja emocjonalna. Psychologia Etologia - Genetyka, 10, 59-82.

Matczak, A. (2004b). Rola temperamentu w rozwoju człowieka. Psychologia Wychowawcza, 9(1), 9-21.

Matczak, A. (2005). Uwarunkowania inteligencji emocjonalnej i kompetencji społeczno-emocjonalnych. Raport końcowy z realizacji projektu 2 H01 F 062 23 w latach 2002-2005. Warszawa.

Matczak, A. (2006). Natura i struktura inteligencji emocjonalnej. Psychologia - Etologia - Genetyka, 13, 59-87.

Matczak, A. (2007a). Rola inteligencji emocjonalnej. Studia Psychologiczne, 45(1), 9-17.

Matczak, A. (2007b). Wstęp. Inteligencja emocjonalna - kierunki i metody badań. Psychologia. Edukacja i społeczeństwo, 4(1), 3-8.

Matczak, A. (2008). Do czego może być potrzebne pojęcie inteligencji emocjonalnej? W: M. Śmieja, J. Orzechowski (red.), Inteligencja emocjonalna. Fakty, mity, kontrowersje. Warszawa: Wydawnictwo Naukowe PWN.

Matczak, A., Jaworowska, A. (2006). Dwuwymiarowy Inwentarz Inteligencji Emocjonalnej DINEMO. Podręcznik. Warszawa: Pracownia Testów Psychologicznych PTP.

Matczak, A., Knopp, K. A. (2013). Znaczenie inteligencji emocjonalnej w funkcjonowaniu człowieka. Warszawa: Liberi Libri.

Matczak, A., Knopp, K. A. (2019). Relationship between temperament and the experiential and strategic components of emotional intelligence. Polish Psychological Bulletin, 50(2) 93-100. https://doi.org/10.24425/ppb.2019.126023

Matczak, A., Piekarska, J. (2011). Test rozumienia emocji TRE. Podręcznik. Warszawa: Pracownia Testów Psychologicznych PTP.

Matczak, A., Piekarska, J., Studniarek, E. (2005). Skala Inteligencji Emocjonalnej SIE-T. Podręcznik. Warszawa: Pracownia Testów Psychologicznych PTP.

Matthews, G., Emo, A. K., Funke, G., Zeidner, M., Roberts, D. R., Costa, P. T. Jr., Schulze, R. (2006). Emotional intelligence, personality, and task-induced stress, 12(2), 96-107. https://doi.org/10.1037/1076-898X.12.2.96

Matthews, G., Zeidner, M., Roberts, R. D. (2002). Emotional intelligence. Science \& myth. Cambridge: The MIT Press. 
Mayer, J. D. (2001). A field guide to emotional intelligence. W: J. Ciarrochi, J. P. Forgas, J. D. Mayer (red.), Emotional intelligence in everyday life: A scientific inquiry (s. 3-24). Nowy Jork: Psychology Press.

Mayer, J. D., Caruso, D. R., Salovey, P. (1999). Emotional intelligence meets traditional standards for an intelligence. Intelligence, 27(4), 267-298. https:// doi.org/10.1016/S0160-2896(99)00016-1

Mayer, J. D., Di Paolo, M. T., Salovey, P. (1990). Perceiving affective content in ambiguous visual stimuli: A component of emotional intelligence. Journal of Personality Assessment, 54(3-4), 772-781. https://doi.org/10.1080/00223 891.1990.9674037

Mayer, J. D., Geher, G. (1996). Emotional intelligence and the identification of emotion. Intelligence, 22(2), 89-113. https://doi.org/10.1016/S01602896(96)90011-2

Mayer, J., Roberts, R., Barsade, S. (2008). Human abilities: Emotional intelligence. Annual Review of Psychology, 59, 507-536. https://doi.org/10.1146/ annurev.psych.59.103006.093646

Mayer, J. D., Salovey, P. (1997). What is emotional intelligence? W: P. Salovey, D. J. Sluyter (red.), Emotional development and emotional intelligence: Educational implications (s. 3-31). Nowy Jork: Basic Books.

Mayer, J. D., Salovey, P. (1999). Czym jest inteligencja emocjonalna? W: P. Salovey, D. J. Sluyter (red.), Rozwój emocjonalny a inteligencja emocjonalna: Problemy edukacyjne (s. 29-69). Poznań: Dom Wydawniczy Rebis.

Mayer, J. D., Salovey, P., Caruso, D. R. (1997). Multifactor Emotional Intelligence Scale (MEIS). Simsbury: Charles J. Wolfe Associates, LLC.

Mayer, J. D., Salovey, P., Caruso, D. R. (2000a). Models of emotional intelligence. W: R. Strenberg (red.), Handbook of intelligence (s. 396-420). Cambridge: Cambridge University. https://doi.org/10.1017/CBO9780511807947.019

Mayer, J. D., Salovey, P., Caruso, D. R. (2000b). Emotional intelligence as Zeitgeist, as personality, and as a mental ability. W: R. Bar-On, J. D. A. Parker (red.), The handbook of emotional intelligence (s. 92-117). San Francisco: Jossey-Bass Inc., A Wiley Company.

Mayer, J. D., Salovey, P., Caruso, D. R. (2002). Mayer-Salovey-Caruso Emotional Intelligence Test (MSCEIT). Toronto: MHS Publishers.

Mayer, J. D., Salovey, P., Caruso, D. R. (2004). Emotional intelligence: Theory, findings, and implications. Psychological Inquiry, 15(3), 197-215. https://doi. org/10.1207/s15327965pli1503_02 
Mayer, J. D., Salovey, P., Caruso, D. R., Sitarenios, G. (2001). Emotional intelligence as a standard intelligence. Emotion, 1(3), 232-242. https://doi. org/10.1037/1528-3542.1.3.232

Mayer, J. D., Salovey, P., Caruso, D. R., Sitarenios, G. (2003). Measuring emotional intelligence with the MSCEIT V2.0. Emotion, 3(1), 97-105. https:// doi.org/10.1037/1528-3542.3.1.97

McCrae, R. R. (2000). Emotional intelligence from the perspective of the Five-Factory Model of Personality. W: R. Bar-On, J. D. A. Parker (red.), The handbook of emotional intelligence (s. 263-176). San Francisco: Jossey-Bars, A Wiley Company.

McCrae, R. R., Costa, P. T. (2005). Osobowość dorosłego człowieka. Perspektywa teorii pięcioczynnikowej. Kraków: Wydawnictwo WAM.

McRae, K., Ochsner, K. N., Mauss, I. B., Gabrieli, J. J. D., Gross, J. J. (2008). Gender differences in emotion regulation: An fMRI study of cognitive reappraisal. Group Processes \& Intergroup Relations, 11(2), 143-162. https:// doi.org/10.1177/1368430207088035

Mehrabian, A., Young, A. L., Sato, S. (1988). Emotional empathy and associated individual differences. Current Psychology Research and Rewiews, 7(3), 221-240.https://doi.org/10.1007/BF02686670

Milles, J., Hempel, S. (2004). The Eysenck personality scales: The Eysenck Personality Questionnaire-Revised (EPQ-R) and the Eysenck Personality Profiles. W: M. J. Hilsenroth, D. L. Segal (red.), Comprehensive handbook of psychological assessment, t. 2: Personality assessment (s. 99-107). New Jersey: John Wiley and Sons.

Moir, A., Jessel, D. (1993). Płeć mózgu. O prawdziwej różnicy między mężczyzna a kobieta. Warszawa: Państwowy Instytut Wydawniczy.

Naghavi, F., Redzuan, M., Mansor, M. (2010). The relationship between alexitymia and emotional intelligence. Asian Social Science, 6(11), 166-170. https:// doi.org/10.5539/ass.v6n11p166

Neubauer, A. C., Freudenthaler, H. H. (2005). Models of emotional intelligence. W: R. Schulze, R. D. Roberts (red.), Emotional intelligence. An international handbook (s. 32-49). Göttingen: Hogrefe \& Huber Publisher.

Newsome, S., Day, A. L., Catano, V. M. (2000). Assessing the predictive validity of emotional intelligence. Personality and Individual Differences, 29(6), 1005-1016. https://doi.org/10.1016/S0191-8869(99)00250-0 
Nęcka, E. (1994). Inteligencja i procesy poznawcze. Kraków: Oficyna Wydawnicza „Impuls”.

Nęcka, E. (2002). Inteligencja. W: J. Strelau (red.), Psychologia. Podręcznik akademicki (t. 2, s. 720-760). Gdańsk: GWP.

Nęcka, E. (2003). Inteligencja: Geneza, struktura, funkcje. Gdańsk: GWP.

Nęcka, E., Orzechowski, J., Szymura, B. (2006). Psychologia poznawcza. Warszawa: Wydawnictwo Naukowe PWN.

Nicolosi, J. J. (2011). Wstyd i utrata przywiazania. Bydgoszcz: Wydawnictwo Mateusza.

Niedenthal, P., Krauth-Gruber, S., Ric, F. (2006). Psychology of emotion: Interpersonal, experiential and cognitive approaches. Nowy Jork: Psychology Press.

Nixon, C. L., Watson, A. (2001). Family experiences and early emotion understanding. Merrill-Palmer Quarterly, 47(2), 300-322. https://doi.org/10.1353/ mpq.2001.0011

Nolen-Hoeksema, S. (1987). Sex differences in uniplar depression: Evidence and theory. Psychological Bulletin, 101(2), 259-282. https://doi. org/10.1037/0033-2909.101.2.259

Norman, K., Combs-Richardson, R. (2001). Emotional intelligence and social skills: Necessary components of hands-on learning in science classes. Journal of Elementary Science Education, 13(2), 1-8.

O'Connor, P. J., Athota, V. (2013). The intervening role of agreeableness in the relationship between emotional intelligence and Machiavellianism: Reassesing the potential dark side of EI. Personality and Individual Differences, 55(7), 750-754. https://doi.org/10.1016/j.paid.2013.06.006

O'Connor, R. M., Little, L. S. (2003). Revisiting the predictive validity of emotional intelligence: Self-report versus ability-based measures. Personality and Individual Differences, 35(8), 1893-1902. http://doi.org/10.1016/S01918869(03)00038-2

Ogińska-Bulik, N. (1992). Temperament a poznawcza koncentracja na bodźcach pochodzących z różnych sfer rzeczywistości. W: A. Eliasz, M. Marszał-Wiśniewska (red.), Temperament a rozwój młodzieży (s. 141-170). Warszawa: Wydawnictwo Instytutu Psychologii PAN. 
Ogińska-Bulik, N. (2005). Emotional intelligence in the workplace: Exploring its effects on occupational stress and health outcomes in human service workers. International Journal of Occupational Medicine and Environmental Health, 18(2), 167-175.

Oleszkiewicz-Zsurzs, Z. (1986). Zapotrzebowanie na stymulację a preferencje do wyboru zawodu. Przeglad Psychologiczny, 29, 509-526.

Oleś, P. K. (2003). Wprowadzenie do psychologii osobowości. Warszawa: Wydawnictwo Naukowe Scholar.

Packiyanathan, M., Nanthagopan, Y. (2020). "Emotional intelligence is a gamechanger" - the effect of emotional intelligence on job performance. The Journal of Business Studies, 04(01), 96-109.

Palmer, B. R., Gignac, G., Manocha, R., Stough, C. (2005). A psychometric evaluation of the Mayer-Salovey-Caruso Emotional Intelligence Test Version 2.0. Intelligence, 33(3), 285-305. https://doi.org/10.1016/j.intell.2004.11.003

Parker, J. D. A., Taylor, G. J., Bagby, R. M. (2001). The relationship between emotional intelligence and alexithymia. Personality and Individual Differences, 30(1), 107-115. https://doi.org/10.1016/S0191-8869(00)00014-3

Parker, S. W., Nelson, C. A. (2005). The impact of early institutional rearing on the ability to discriminate facial expressions of emotion: An event-related potential study. Child Development, 76(1), 54-73. https://doi.org/10.1111/ j.1467-8624.2005.00829.x

Paulhus, D., Williams, K. M. (2002). The Dark Triad of personality: Narcissism, Machiavellianism and psychopathy. Journal of Research in Personality, 36(6), 556-563. https://doi.org/10.1016/S0092-6566(02)00505-6

Pawłow, J. P. (1952). Dwadzieścia lat badań wyższej czynności nerwowej (zachowania się) zwierząt. Warszawa: PZWL.

Pellitteri, J. (2002). The relationship between emotional intelligence and ego defense mechanisms. The Journal of Psychology: Interdisciplinary and Applied, 136(2), 182-194. https://doi.org/10.1080/00223980209604149

Pennebaker, J. W., Rimé, B., Blankenship, V. E. (1996). Stereotypes of emotional expressiveness of northerners and southerners: A cross-cultural test of Montesquieu's hypotheses. Journal of Personality and Social Psychology, 70(2), 372-380. https://doi.org/10.1037/0022-3514.70.2.372

Petrides, K. V. (2009). Technical manual for the Trait Emotional Intelligence Questionnaires (TEIQue). Londyn: London Psychometric Laboratory. https://doi.org/10.1007/978-0-387-88370-0_5 
Petrides, K. V., Furnham, A. (2000a). On the dimensional structure of emotional intelligence. Personality and Individual Differences, 29(2), 313-320. https://doi.org/10.1016/S0191-8869(99)00195-6

Petrides, K. V., Furnham, A. (2000b). Gender differences in measured and self-estimated trait emotional intelligence. Sex Roles: A Journal of Research, 42(5), 449-461. https://doi.org/10.1023/A:1007006523133

Petrides, K. V., Furnham, A. (2001). Trait emotional intelligence: Psychometric investigation with reference to established trait taxonomies. European Journal of Psychology, 15(6), 425-448. https://doi.org/10.1002/per.416

Petrides, K. V., Furnham, A. (2003). Trait emotional intelligence: Behavioural validation in two studies of emotion recognition and reactivity to mood induction. European Journal of Personality, 17(1), 39-57. https://doi. org/10.1002/per.466

Petrides, K. V., Pita, R., Kokkinaki, F. (2007). The location of trait emotional intelligence in personality factor space. British Journal of Psychology, 98(2), 273-289. https://doi.org/10.1348/000712606x120618

Petrides, K. V., Vernon, P. A., Aitken Schermer, J., Veselka, L. (2011). Trait emotional intelligence and the Dark Triad traits of personality. Twin Research and Human Genetics, 14(1), 35-41. https://doi.org/10.1375/twin.14.1.35

Piekarska, J. (2004). Inteligencja emocjonalna młodzieży a sposoby reagowania rodziców w sytuacjach problemowych. Psychologia Rozwojowa, 9(1), 23-33.

Piekarska, J. (2010). Temperamentalne uwarunkowania inteligencji emocjonalnej. Psychologia - Etologia - Genetyka, 21, 55-76.

Pinker, S. (2009). Paradoks płci. Warszawa: Wydawnictwo Czarna Owca.

Piotrowska, A. (1988). Dwa rodzaje inteligencji ogólnej i sposoby ich pomiaru. Psychologia Wychowawcza, 31, 347-356.

Piotrowska, A. (1997). Z badań nad inteligencją społeczną. Psychologia Wychowawcza, 40, 289-300.

Platon (2002). Fajdros. Kęty: Wydawnictwo „Antyk”.

Plopa, M. (1983). Funkcjonowanie społeczno-emocjonalne młodzieży a percepcja postaw matek i ojców. Psychologia Wychowawcza, 26(2), 129-142.

Plopa, M. (2008a). Psychologia rodziny. Teoria i badania. Kraków: Oficyna Wydawnicza „Impuls”.

Plopa, M. (2008b). Kwestionariusz retrospektywnej oceny postaw rodziców (KPR-Roc). Podręcznik. Warszawa: Vizja Press \& IT. 
Polce-Lynch, M., Myers, B. J., Kilmartin, C. T., Forssmann-Falck, R., Kliewer, W. (1998). Gender and age patterns in emotional expression, body image and self-esteem: A qualitative analysis. Sex Roles: A Journal of Research, 38(11/12), 1026-1048.

Pospiszyl, K. (1978). Różnice psychologiczne między dziewczętami a chłopcami. Psychologia Wychowawcza, 2, 135-149.

Pospiszyl, K. (1992). Psychologia kobiety. Warszawa: Petra.

Promińska, E. (1987). Płeć człowieka. Biologiczne podstawy różnic. Wrocław: Ossolineum.

Przetacznik-Gierowska, M., Włodarski, Z. (1998). Psychologia wychowawcza. Czesść II. Warszawa: Wydawnictwo Naukowe PWN.

Rembowski, J. (1972). Więzi uczuciowe w rodzinie. Warszawa: PWN.

Roberts, R. D., Zeidner, M., Matthews, G. (2001). Does emotional intelligence meet traditional standards for an intelligence? Some new data and conclusions. Emotion, 1(3), 196-231. https://doi.org/10.1037/1528-3542.1.3.196

Robinson, M. D., Johnson, J. T. (1997). Is it emotion or is it stress? Gender stereotypes and the perception of subjective experience. Sex Roles: A Journal of Research, 36(3-4), 235-258. https://doi.org/10.1007/BF02766270

Rosenthal, R., DePaulo, B. M. (1979). Sex differences in accommodation in nonverbal communication. W: R. Rosenthal (red.), Skill in nonverbal communication: Individual differences (s. 68-103). Cambridge: Oelgeschlager, Gunn \& Hain.

Rothbart, M. K., Derryberry, D. (1981). Development of individual differences in temperament. W: M. E. Lamb, A. L. Brown (red.), Advances in developmental psychology (s. 37-86). Hillsdale: Erlbaum.

Russo, M. P., Mancini, G., Trombini, E., Baldaro, B., Mavroveli, S., Petrides, K. V. (2012). Trait emotional intelligence and the Big Five: A study on Italian children and preadolescents. Journal of Psychoeducational Assessment, 30(3), 274-283. https://doi.org/10.1177/0734282911426412

Ryś, M. (1992). Wpływ dzieciństwa na późniejsze życie w małżeństwie i rodzinie. Warszawa: Wydawnictwo Fundacji ATK.

Saarni, C. (1999). Kompetencja emocjonalna i samoregulacja w dzieciństwie. W: P. Salovey, D. J. Sluyter (red.), Rozwój emocjonalny a inteligencja emocjonalna (s. 75-125). Poznań: Dom Wydawniczy Rebis. 
Saklofske, D. H., Austin, E. J., Minski, P. S. (2003). Factor structure and validity of a trait emotional intelligence measure. Personality and Individual Differences, 34(4), 707-721. https://doi.org/10.1016/S0191-8869(02)00056-9

Salovey, P., Bedell, B. T., Detweiler, J. B., Mayer, J. D. (2000). Current directions in emotional intelligence research. W: M. Lewis, J. M. Haviland-Jones (red.), Handbook of emotions (s. 504-520). Nowy Jork: Guilford Press.

Salovey, P., Bedell, B. T., Detweiler, J. B., Mayer, J. D. (2005). Aktualne kierunki badań nad inteligencją emocjonalną. W: M. Lewis, J. M. Haviland-Jones (red.), Psychologia emocji (s. 634-654). Gdańsk: GWP.

Salovey, P., Mayer, J. D. (1990). Emotional intelligence. Imagination, Cognition and Personality, 9(3), 185-211. https://doi.org/10.2190/DUGG-P24E$52 \mathrm{WK}-6 \mathrm{CDG}$

Salovey, P., Mayer, J. D., Goldman, S. L., Turvey, C., Palfai, T. P. (1995). Emotional attention, clarity and repair: Exploring emotional intelligence using the Trait Meta Mood Scale. W: J. W. Pennebaker (red.), Emotion, disclosure and health (s. 125-154). Washington: American Psychological Association. https://doi.org/10.1037/10182-006

Sánchez-Núñez, M. T., Fernández-Berrocal, P., Montañés, J., Latorre, J. M. (2008). Does emotional intelligence depend on gender? The socialization of emotional competencies in men and women and its implications. Electronic Journal of Research in Educational Psychology, 6(2), 455-474. http://www. investigacion-psicopedagogica.org/revista/articulos/15/english/Art_15_253. pdf

Scharfe, E. (2000). Development of emotional expression, understanding, and regulation in infants and young children. W: R. Bar-On, J. D. A. Parker (red.), The handbook of emotional intelligence (s. 244-262). San Francisco: Jossey-Bass Inc., A Wiley Company.

Schore, A. N. (2001). The effects of early relationship trauma on right brain development, affect regulation, and infant mental health. Infant Mental Health Journal, 22(1-2), 201-269. https://doi.org/10.1002/1097-0355(200 101/04)22:1<201::AID-IMHJ8>3.0.CO;2-9

Schulte, M. J., Ree, M. J., Carretta, T. R. (2004). Emotional intelligence: Not much more than $g$ and personality. Personality and Individual Differences, 37(5), 1059-1068. https://doi.org/10.1016/j.paid.2003.11.014 
Schutte, N. S., Malouff, J. M., Bobik, C., Coston, T. D., Greeson, C., Jedlicka, C., Rhodes, E., Wendorf, G. (2001). Emotional intelligence and interpersonal relations. The Journal of Social Psychology, 141(4), 523-536. https://doi. org/10.1080/00224540109600569

Schutte, N. S., Malouff, J. M., Hall, J. E., Haggerty, D. J., Cooper, J. T., Golden, C. J., Dornheim, L. (1998). Development and validation of a measure of emotional intelligence. Personality and Individual Differences, 25, 167-177.

Schutte, N. S., Malouff, J. M., Simunek, M., McKenley, J., Hollander, S. (2002). Characteristic emotional intelligence and emotional well-being. Cognition and Emotion, 16(6), 769-785. https://doi.org/10.1080/02699930143000482

Shaffer, D. R. (2000). Social and personality development. Belmont: Wadsworth, Thomson Learning.

Shagini, U., Fiori, M., Bausseron, E. (2019). Emotional intelligence and performance in a stressful task: The mediating role of self-efficacy. Personality and Individual Differences, 156. https://doi.org/10.1016/j.paid.2019.109790

Shapiro, E. L., (1999). Jak wychować dziecko o wysokim EQ? Przewodnik dla rodziców. Warszawa: Prószyński i S-ka.

Simon, R. W., Nath, L. E. (2004). Gender and emotion in the United States: Do men and women differ in self-reports of feelings and expressive behavior? American Journal of Sociology, 109(5), 1137-1176. https://doi. org $/ 10.1086 / 382111$

Siuta, J. (2006). Inwentarz Osobowości NEO-PI-R Paula T. Costy Jr. i Roberta R. McCrae. Adaptacja polska. Podręcznik. Warszawa: Pracownia Testów Psychologicznych Polskiego Towarzystwa Psychologicznego.

Snodgrass, S. E. (1992). Further effects of role versus gender on interpersonal sensitivity. Journal of Personality and Social Psychology, 62(1), 154-158. https://doi.org/10.1037/0022-3514.62.1.154

Strelau, J. (1978). Rola temperamentu w rozwoju psychicznym. Warszawa: WSiP. Strelau, J. (red.). (1982). Regulacyjne funkcje temperamentu. Wrocław, Warszawa: Zakład Narodowy im. Ossolińskich, Wydawnictwo Polskiej Akademii Nauk.

Strelau, J. (1985). Temperament, osobowość, działanie. Warszawa: PWN.

Strelau, J. (1987). O inteligencji człowieka. Warszawa: Wiedza Powszechna.

Strelau, J. (1992). Badania nad temperamentem. Teoria, diagnoza, zastosowania. Wrocław, Warszawa: Zakład Narodowy im. Ossolińskich, Wydawnictwo Polskiej Akademii Nauk. 
Strelau, J. (1997). Inteligencja człowieka. Warszawa: Wydawnictwo „Żak”.

Strelau, J. (1998). Psychologia temperamentu. Warszawa: Wydawnictwo Naukowe PWN.

Strelau, J. (2002). Psychologia różnic indywidualnych. Warszawa: Wydawnictwo Naukowe Scholar.

Strelau, J. (2006). Temperament jako regulator zachowania. Z perspektywy pótwiecza badań. Gdańsk: GWP.

Strelau, J., Zawadzki, B. (1998). Kwestionariusz temperamentu PTS. Warszawa: Pracownia Testów Psychologicznych PTP.

Szczepaniak, P., Strelau, J., Wrześniewski, K. (1996). Diagnoza stylów radzenia sobie ze stresem za pomocą polskiej wersji kwestionariusza CISS Endlera i Parkera. Przeglad Psychologiczny, 39, 187-210.

Szcześniak, M., Rodzeń, W., Malinowska, A., Kroplewski, Z. (2020). Big Five personality traits and gratitude: The role of emotional intelligence. Psychology Research and Behavior Management, 13, 977-1088. https://doi. org/10.2147/PRBM.S268643

Szcześniak, M., Strochalska, K. (2019). Temperament and sense of coherence: Emotional intelligence as a mediator. International Journal of Environmental Research and Public Health, 17(1), 219. https://doi.org/10.3390/ ijerph17010219

Szczygieł, D. (2006). Zdolność czy cecha osobowości? Kontrowersje wokół definicji i pomiaru inteligencji emocjonalnej. W: E. Martynowicz (red.), Od poczucia podmiotowości do bycia ofiara (s. 85-110). Kraków: Oficyna Wydawnicza Impuls.

Szczygieł, D. (2007). Zdolniejsze kobiety czy mniej zmotywowani mężczyźni? Różnice między płciami w zróżnicowaniu i złożoności werbalizacji emocji. Psychologia. Edukacja i Społeczeństwo, 4, 47-66.

Szczygieł, D., Jasielska, A., Wytykowska, A. (2015). Psychometric properties of the Polish version of the Trait Emotional Intelligence Questionnaire-Short Form. Polish Psychological Bulletin, 46(3), 447-459. https://doi.org/10.1515/ ppb-2015-0051

Szczygieł, D., Kiełkiewicz, J. (2005). Inteligencja emocjonalna i powodzenie szkolne. Psychologia Rozwojowa, 10, 59-68.

Szczygieł, D., Kolańczyk, A. (2000). Skala poziomów świadomości emocji. Adaptacja skali Levels of Emotional Awareness Scale Lane'a i Schwartza. Roczniki Psychologiczne, 3, 155-179. 
Szpitalak, M., Polczyk, R. (2009). Czynnik Ekstrawertyczność w Pięcioczynnikowej Teorii Osobowości. W: J. Siuta (red.), Diagnoza osobowości. Inwentarz NEO-PI-R $w$ teorii i $w$ praktyce (s. 33-52). Warszawa: Pracownia Testów Psychologicznych PTP.

Szydłowski, P. (2019). Style poznawcze a religijność. Warszawa: Liberi Libri.

Śmieja, M. (2018). W związku $z$ inteligencją emocjonalną. Rola inteligencji emocjonalnej $w$ relacjach społecznych i związkach intymnych. Kraków: Wydawnictwo UJ.

Śmieja, M., Orzechowski, J. (red.). (2008). Inteligencja emocjonalna. Fakty, mity, kontrowersje. Warszawa: Wydawnictwo Naukowe PWN.

Śmieja, M., Orzechowski, J., Beauvale, A. (2007). TIE - Test Inteligencji Emocjonalnej. Studia Psychologiczne, 54, 80-99.

Taylor, G. J., Parker, J. D. A., Bagby, R. M. (1999). Emotional intelligence and the emotional brain: Points of convergence and implications for psychoanalysis. Journal of the American Academy of Psychoanalysis, 27(3), 339-354.

Thoits, P. A. (1989). The sociology of emotions. Annual Review of Sociology, 15, 317-342. https://doi.org/10.1146/annurev.so.15.080189.001533

Thomas, A., Chess, S. (1977). Temperament and development. Nowy Jork: Brunner/Mazel.

Thomas, C. E., Richmond, V. P., McCroskey, J. C. (1994). The association between immediacy and socio-communicative style. Communication Research Reports, 11, 107-115.

Trobst, K. K., Collins, R. L., Embree, J. M. (1994). The role of emotion in social support provision: Gender, empathy and expression of distress. Journal of Social and Personal Relationship, 11(1), 45-62. https://doi. org/10.1177/0265407594111003

Van der Zee, K., Thijs, M., Schakel, L. (2002). The relationship of emotional intelligence with academic intelligence and the Big Five. European Journal of Personality, 16(2), 103-125. https://doi.org/10.1002/per.434

Van Rooy, D. L., Alonso, A., Viswesvaran, C. (2005). Group differences in emotional intelligence scores: Theoretical and pratical implications. Personality and Individual Differences, 38(3), 689-700. https://doi.org/10.1016/j. paid.2004.05.023 
Vernon, P. A., Villani, V. C., Schermer, J. A., Petrides, K. V. (2008). Phenotypic and genetic associations between the Big Five and trait emotional intelligence. Twin Research and Human Genetics, 11(5), 524-530. https://doi. org/10.1375/twin.11.5.524

Wagner, H., Lee, V. (2008). Alexithymia and individual differences in emotional expression. Journal of Research in Personality, 42(1), 83-95. https://doi. org/10.1016/j.jrp.2007.04.001

Warwick, J., Nettelbeck, T. (2004). Emotional intelligence is...? Personality and Individual Differences, 37(5), 1091-1100. https://doi.org/10.1016/j. paid.2003.12.003

Wilks, F. (1999). Inteligentne emocje. Warszawa: Jacek Santorski \& Co i Wydawnictwo Wilga.

Windle, M., Lerner, R. (1986). Reassessing the dimensions of temperamental individuality across the life span: The Revised Dimensions of Temperament Survey (DOTS-R). Journal of Adolescent Research, 1, 213-229. https://doi. org/10.1177/074355488612007

Wojciszke, B. (red.). (2002). Kobiety i mężczyźni: odmienne spojrzenia na różnice. Gdańsk: GWP.

Wojciszke, B. (2006). Psychologia miłości. Intymność. Namiętność. Zaangażowanie. Gdańsk: GWP.

Wytykowska, A., Petrides, K. V. (2007). Inteligencja emocjonalna jako dyspozycja. Polska adaptacja skali do badania inteligencji emocjonalnej jako cechy: TEIQue Petridesa i Furnhama. Psychologia. Edukacja i Społeczeństwo, 4(1), 97-110.

Young, J. E., Klosko, J. S. (2012). Program zmiany sposobu życia. Uwalnianie się od psychologicznych pułapek. Warszawa: Wydawnictwo Zielone Drzewo Instytutu Psychologii Zdrowia PTP.

Young, J. E., Klosko, J. S., Weishaar, M. E. (2015). Terapia schematów. Przewodnik praktyka. Sopot: GWP.

Zajonc, R. B. (1980). Feeling and thinking: Preferences need no inferences. American Psychologist, 35(2), 151-175. https://doi.org/10.1037/0003066X.35.2.151

Zawadzki, B., Strelau, J. (1997). Formalna charakterystyka zachowania - Kwestionariusz temperamentu (FCZ-KT). Podręcznik. Warszawa: Pracownia Testów Psychologicznych PTP. 
Zawadzki, B., Strelau, J., Szczepaniak, P., Śliwińska, M. (1998). Inwentarz osobowości NEO-FFI Costy i McCrae. Adaptacja polska. Podręcznik. Warszawa: Pracownia Testów Psychologicznych PTP.

Zhou, Q., Eisenberg, N., Losoya, S. H., Fabes, R. A., Reiser, M., Guthrie, I. K., Murphy, B. C., Cumberland, A. J., Shepard, S. A. (2002). The relations of parental warmth and positive expressiveness to children's empathy-related responding and social functioning: A longitudinal study. Child Development, 73(3), 893-915. https://doi.org/10.1111/1467-8624.00446

Zeidner, M. (2008). Rozwój inteligencji emocjonalnej. Czego dowiedzieliśmy się do tej pory? W: M. Śmieja, J. Orzechowski (red.), Inteligencja emocjonalna. Fakty, mity, kontrowersje (s. 82-110). Warszawa: Wydawnictwo Naukowe PWN.

Zeidner, M., Matthews, G., Roberts, R. D., MacCann, C. (2003). Development of emotional intelligence: Towards a multi-level investment model. Human Development, 46, 69-96. https://doi.org/10.1159/000068580

Zeidner, M., Shani-Zinovich, I., Matthews, G., Roberts, R. D. (2005). Assessing emotional intelligence in gifted and non-gifted high school children students: Outcomes depend on the measure. Intelligence, 33(4), 369-391. http://doi.org/10.1016/j.intell.2005.03.001

Ziemska, M. (1973). Postawy rodzicielskie. Warszawa: Wiedza Powszechna.

Ziemska, M. (1986). Rodzina a osobowość. Warszawa: Wiedza Powszechna. 


\section{ZAŁĄCZNIKI}

\section{Załącznik A. Wyniki temperamentu w grupie kobiet i mężczyzn}

Tabela A1

Porównanie kobiet $(\mathrm{N}=415)$ i mężczyzn $(\mathrm{N}=301)$ w zakresie cech temperamentu

\begin{tabular}{|c|c|c|c|c|}
\hline & Kobiety & Mężczyźni & & \\
\hline Zmienna & śr. ranga & śr. ranga & $\boldsymbol{U}$ & Efekt $r$ \\
\hline ŻW & 346,70 & 374,77 & 57561,5 & 0,07 \\
\hline PE & 411,50 & 285,43 & $40464,0^{* * *}$ & 0,30 \\
\hline WS & 381,23 & 327,16 & $53024,5^{* * *}$ & 0,13 \\
\hline RE & 422,95 & 269,64 & $35709,5^{* * *}$ & 0,37 \\
\hline AK & 360,72 & 355,44 & 61536,0 & 0,01 \\
\hline WT & 313,18 & 420,98 & $43651,0^{* * *}$ & 0,26 \\
\hline
\end{tabular}

Adnotacja. Skale FCZ-KT: ŻW - żwawość; PE - perseweratywność; WS - wrażliwość sensoryczna; RE - reaktywność emocjonalna; AK - aktywność; WT - wytrzymałość. *** $p<0,001$. 


\section{Tabela A2}

Liczebności uzyskanych profilów temperamentu uwzględniających zarówno możliwości przetwarzania stymulacji, jak i strukturę temperamentu (zharmonizowana lub niezharmonizowana $) u$ kobiet $(\mathrm{N}=415)$ i mężczyzn $(\mathrm{N}=301)$

\begin{tabular}{|c|c|c|c|c|}
\hline \multirow[b]{2}{*}{$\begin{array}{l}\text { Typ struktury tem- } \\
\text { peramentu }\end{array}$} & \multicolumn{2}{|c|}{ Kobiety } & \multicolumn{2}{|c|}{ Mężczyźni } \\
\hline & $N$ & $\%$ & $N$ & $\%$ \\
\hline $\begin{array}{l}\text { Zharmonizowany } \\
\text { o dużych możliwo- } \\
\text { ściach przetwarzania } \\
\text { stymulacji }\end{array}$ & 72 & $17,3 \%$ & 57 & $18,9 \%$ \\
\hline $\begin{array}{l}\text { Zharmonizowany } \\
\text { o małych możliwo- } \\
\text { ściach przetwarzania } \\
\text { stymulacji }\end{array}$ & 70 & $16,9 \%$ & 47 & $15,6 \%$ \\
\hline $\begin{array}{l}\text { Niezharmonizowany } \\
\text { o dużych możliwo- } \\
\text { ściach przetwarzania } \\
\text { stymulacji }\end{array}$ & 27 & $6,5 \%$ & 22 & $7,3 \%$ \\
\hline $\begin{array}{l}\text { Niezharmonizowany } \\
\text { o małych możliwo- } \\
\text { ściach przetwarzania } \\
\text { stymulacji }\end{array}$ & 42 & $10,1 \%$ & 20 & $6,6 \%$ \\
\hline Niezróżnicowany & 204 & $49,2 \%$ & 155 & $51,5 \%$ \\
\hline
\end{tabular}




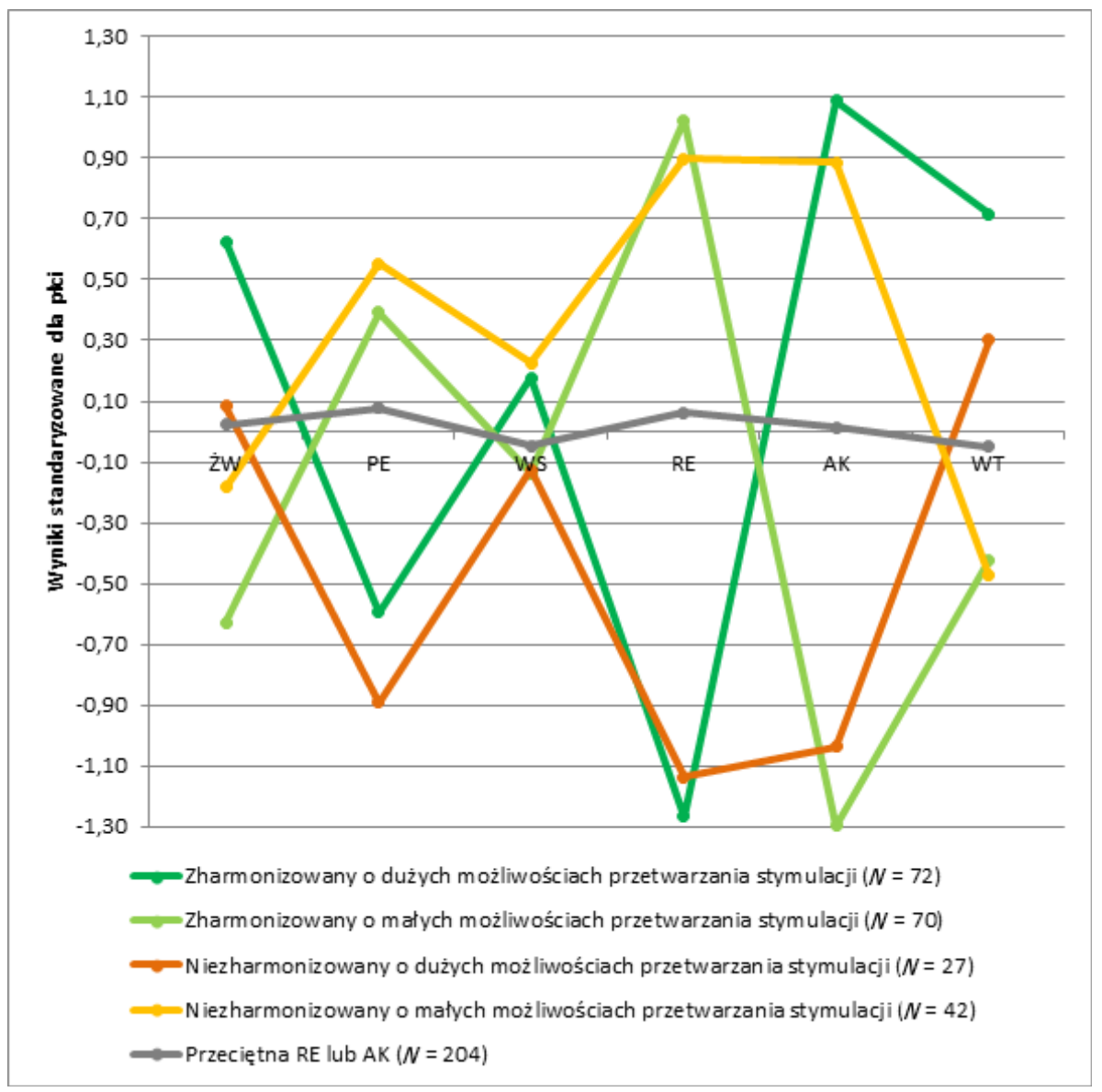

Rysunek A1. Uśrednione profile temperamentu u kobiet.

Adnotacja. Skale FCZ-KT: ŻW - żwawość; PE - perseweratywność; WS - wrażliwość sensoryczna; RE - reaktywność emocjonalna; AK - aktywność; WT - wytrzymałość. 


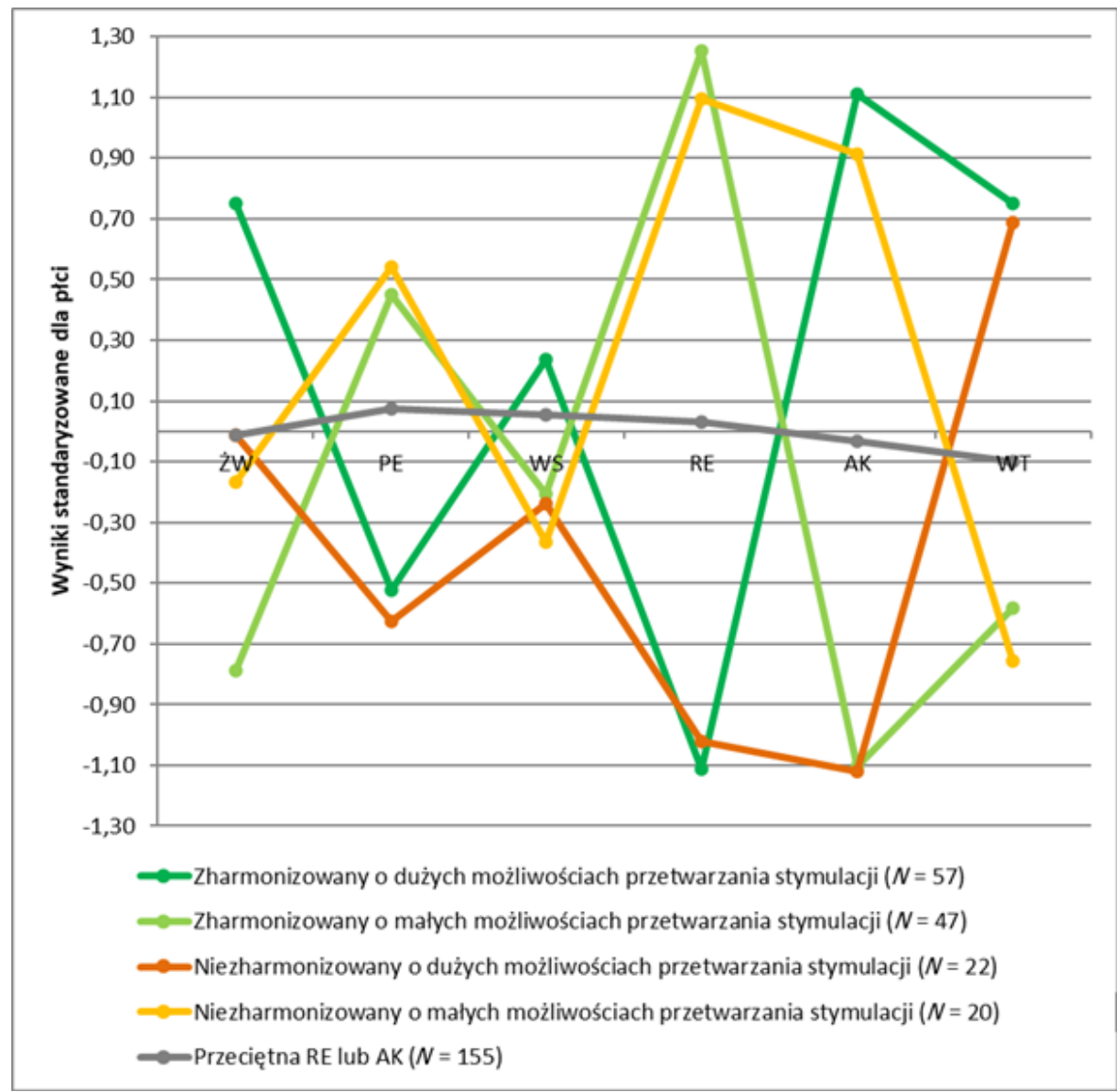

Rysunek A2. Uśrednione profile temperamentu u mężczyzn.

Adnotacja. Skale FCZ-KT: ŻW - żwawość; PE - perseweratywność; WS - wrażliwość sensoryczna; RE - reaktywność emocjonalna; AK - aktywność; WT - wytrzymałość. 


\section{Załącznik B. Korelacje pomiędzy inteligencją emocjonalną a temperamentem}

Tabela B1

Współczynniki korelacji pomiędzy wskaźnikami inteligencji emocjonalnej a wskaźnikami cech temperamentu dla ogółu badanych $(\mathrm{N}=716)$

\begin{tabular}{ccccccc}
$\begin{array}{c}\text { Zmien- } \\
\text { na }\end{array}$ & $\mathbf{Z} \mathbf{W}$ & $\mathbf{P E}$ & $\mathbf{W S}$ & $\mathbf{R E}$ & $\mathbf{A K}$ & $\mathbf{W T}$ \\
\hline AKC & $0,18^{* * *}$ & $-0,04$ & $0,15^{* * *}$ & $-0,22^{* * *}$ & $0,26^{* * *}$ & $0,09^{* * *}$ \\
EMP & $0,11^{* * *}$ & 0,02 & $0,19^{* * *}$ & $-0,02$ & $0,08^{* *}$ & 0,03 \\
ROZ & $0,20^{* * *}$ & $-0,29^{* * *}$ & $0,07^{* *}$ & $-0,37^{* * *}$ & 0,03 & $0,25^{* * *}$ \\
KON & $0,22^{* * *}$ & $-0,22^{* * *}$ & $0,14^{* * *}$ & $-0,32^{* * *}$ & $0,06^{*}$ & $0,19^{* * *}$ \\
WO & $0,28^{* * *}$ & $-0,15^{* * *}$ & $0,23^{* * *}$ & $-0,31^{* * *}$ & $0,16^{* * *}$ & $0,12^{* * *}$ \\
\hline
\end{tabular}

Adnotacja. Skale FCZ-KT: ŻW - żwawość; PE - perseweratywność; WS - wrażliwość sensoryczna; RE - reaktywność emocjonalna; AK - aktywność; WT - wytrzymałość. Skale PKIE: AKC - akceptowanie; EMP - empatia; KON - kontrola; ROZ - rozumienie; WO - wynik ogólny w PKIE.

${ }^{\star} p<0,05 ;{ }^{* *} p<0,01 ;{ }^{* *} p<0,001$. 


\section{Załącznik C. Analiza kanoniczna}

Analiza kanoniczna dla sześciu cech temperamentu i inteligencji emocjonalnej traktowanej jako układ wyników skal akceptowania, empatii i kontroli (tabela C1 i C2).

Tabela C1

Korelacje kanoniczne między temperamentem a inteligencja emocjonalna (AKC, EMP, KON) w grupie kobiet

\begin{tabular}{ccccc}
\hline $\mathrm{Nr}$ & $\mathrm{Rc}$ & $\mathrm{Rc}^{2}$ & $\mathrm{RIIE}$ & $\mathrm{RIT}$ \\
\hline 1 & $0,54^{* * *}$ & 0,29 & $12,83 \%$ & $9,57 \%$ \\
2 & $0,33^{* * *}$ & 0,11 & $2,93 \%$ & $1,81 \%$ \\
3 & $0,22^{* *}$ & 0,05 & $1,40 \%$ & $0,68 \%$ \\
\hline
\end{tabular}

Adnotacja. $R_{\mathrm{c}}$ - współczynnik korelacji kanonicznej; $R I_{\mathrm{IE}}$ - wskaźnik redundancji dla inteligencji emocjonalnej; $R I_{\mathrm{T}}$ - wskaźnik redundancji dla temperamentu.

${ }^{* *} p<0,01 ;{ }^{* * *} p<0,001$.

Tabela C2

Korelacje kanoniczne między temperamentem a inteligencja emocjonalna (AKC, EMP, KON) w grupie mężczyzn

\begin{tabular}{ccccc}
\hline $\mathbf{N r}$ & $\mathbf{R c}$ & $\mathbf{R c}^{\mathbf{2}}$ & $\mathbf{R I I E}$ & $\mathbf{R I T}$ \\
\hline 1 & $0,65^{* * *}$ & 0,42 & $19,10 \%$ & $16,36 \%$ \\
2 & $0,48^{* * *}$ & 0,23 & $6,72 \%$ & $3,93 \%$ \\
3 & $0,28^{* * *}$ & 0,08 & $1,93 \%$ & $1,05 \%$ \\
\hline
\end{tabular}

Adnotacja. $R_{\mathrm{c}}$ - współczynnik korelacji kanonicznej; $R I_{\mathrm{IE}}$ - wskaźnik redundancji dla inteligencji emocjonalnej; $R I_{\mathrm{T}}$ - wskaźnik redundancji dla temperamentu.

Struktura zmiennych kanonicznych. Analiza kanoniczna uwzględniająca inteligencję emocjonalną rozumianą jako cztery skale PKIE ujawniła silne zależności między nimi. Aby zinterpretować, na czym polegają istotne 
zależności, przedstawiono strukturę każdej pary zmiennych kanonicznych. W tabelach od C3 do C8 uwzględniono wagę, ładunek i ładunek krzyżowy. Waga to mnożnik, przez który pomnożono zmienną, by zmienna kanoniczna była jak najsilniej skorelowana z przeciwną zmienną kanoniczną - im dalej od zera jest waga, tym większy jest udział zmienności wystandaryzowanej zmiennej w zmienności funkcji kanonicznej. Wagi są wrażliwe na zmianę próby.

Ładunek to korelacja między zmienną a zmienną kanoniczną - szczególnie warto brać go pod uwagę, gdy zmienne wyjściowe z zestawu tworzącego funkcję kanoniczną są ze sobą skorelowane (wspólna wariancja tych dwu zmiennych nie jest dwukrotnie ważona, więc jedna waga jest wyraźnie wyższa od drugiej). Struktura kanoniczna (canonical structure), czyli macierz ładunków (loadings) to szereg prostych korelacji między zmiennymi wyjściowymi a ich własną zmienną kanoniczną. Kwadrat ładunku informuje, jaki jest procent wspólnej wariancji zmiennej i zmiennej kanonicznej. Inaczej - jak blisko zmienna kanoniczna jest związana ze zmienną.

Ładunek krzyżowy (cross-loading) jest korelacją między zmienną wyjściową a przeciwną zmienną kanoniczną. Otrzymuje się go, mnożąc klasyczny ładunek przez współczynnik korelacji kanonicznej. Ładunek krzyżowy niesie informację, która jest bardzo ważna w interpretacji korelacji - odnosi się nie do struktury kompozytów liniowych tej samej zmiennej, lecz dotyczy tego, co badacza interesuje najbardziej (Hair i in., 2009) - zależności między zmienną zależną i niezależną. W tabelach zmienne $\mathrm{z}$ obu zestawów zostały przedstawione razem, choć ich współczynniki dotyczą odmiennych zmiennych kanonicznych.

Wagi i ładunki przedstawiają trochę inny obraz struktury zmiennych kanonicznych. Można zauważyć, że najsilniej skorelowane z pierwszą funkcją kanoniczną inteligencji emocjonalnej są skale kontroli i rozumienia, tzn. strategiczna inteligencja emocjonalna. Wyraźnie różne wagi przypisane tym skalom przy obu wysokich ładunkach świadczą o istnieniu znaczącej korelacji między tymi dwoma składnikami inteligencji emocjonalnej.

Wśród zmiennych temperamentalnych zdecydowanie największy wkład w budowanie pierwszej zmiennej kanonicznej ma reaktywność emocjonalna. Jej związek z pierwszą zmienną kanoniczną jest prawie pełny, a waga - największa. Dość silne ładunki - rzędu 0,6 - występują dla parametrów temperamentu: perseweratywność i wytrzymałość, a ich niskie 
wagi (zwłaszcza wytrzymałości) wskazują na powiązanie tych zmiennych $\mathrm{z}$ reaktywnością emocjonalną.

Znaki ładunków i „ładunków krzyżowych” niosą informację, że najsilniejsza zależność między temperamentem a inteligencją emocjonalną polega na tym, że wysoka reaktywność emocjonalna wiąże się z niską strategiczną inteligencją emocjonalną. Związek ten może być klasyfikowany jako silny.

Struktura korelacji kanonicznych w próbie kobiet (tabela C3) i w próbie mężczyzn (tabela C4) przedstawia się następująco:

\section{Tabela C3}

Wskaźniki do interpretacji udziału poszczególnych zmiennych w pierwszym pierwiastku kanonicznym $w$ grupie kobiet $(\mathrm{N}=415)$

\begin{tabular}{ccccc}
\hline Zestaw & Zmienna & Waga & $\mathbf{L}$ & $\mathbf{\Lambda}$ \\
\hline & AKC & $-0,40$ & $-0,66$ & $-0,37$ \\
Inteligencja & KON & $-0,59$ & $-0,30$ & $-0,17$ \\
emocjonalna & ROZ & $-0,26$ & $-0,81$ & $-0,47$ \\
& ZWW & $-0,09$ & $-0,51$ & $-0,44$ \\
& PE & 0,17 & 0,51 & $-0,28$ \\
Tempera- & WS & $-0,33$ & $-0,37$ & $-0,28$ \\
ment & RE & 0,78 & 0,94 & 0,52 \\
& AK & $-0,02$ & $-0,33$ & $-0,18$ \\
& WT & $-0,03$ & 0,55 & $-0,30$ \\
\hline
\end{tabular}

Adnotacja. L - ładunek (loading) - korelacja zmiennej z własną zmienną kanoniczną; $\Lambda$ - „przeciwładunek” (cross-loading) - korelacja zmiennej z przeciwną zmienną kanoniczną. Skale FCZ-KT: ŻW - żwawość; PE - perseweratywność; WS - wrażliwość sensoryczna; RE - reaktywność emocjonalna; AK - aktywność; WT - wytrzymałość. Skale PKIE: AKC - akceptowanie; EMP - empatia; KON - kontrola; ROZ - rozumienie.

U kobiet pierwsza korelacja kanoniczna opiera się na zależności między reaktywnością emocjonalną a inteligencją emocjonalną strategiczną. 
Mniejszy, ale też ważny, wkład w tę relację mają wyniki dotyczące akceptacji emocji.

\section{Tabela C4}

Wskaźniki do interpretacji udziału poszczególnych zmiennych w pierwszym pierwiastku kanonicznym w grupie mężczyzn $(\mathrm{N}=301)$

\begin{tabular}{ccccc}
\hline Zestaw & Zmienna & Waga & $\mathbf{L}$ & $\mathbf{\Lambda}$ \\
\hline & AKC & $-0,37$ & $-0,68$ & $-0,45$ \\
Inteligencja & KON & $-0,58$ & $-0,86$ & $-0,57$ \\
emocjonalna & ROZ & $-0,30$ & $-0,83$ & $-0,55$ \\
& ŻW & $-0,11$ & $-0,66$ & $-0,44$ \\
& PE & 0,16 & 0,58 & 0,38 \\
& WS & $-0,27$ & $-0,41$ & $-0,27$ \\
& RE & 0,76 & 0,95 & 0,62 \\
Temperament & AK & $-0,07$ & $-0,41$ & $-0,27$ \\
& WT & 0,04 & 0,59 & $-0,39$ \\
\hline
\end{tabular}

Adnotacja. L - ładunek (loading) - korelacja zmiennej z własną zmienną kanoniczną; $\Lambda$ - „przeciwładunek” (cross-loading) - korelacja zmiennej z przeciwną zmienną kanoniczną. Skale FCZ-KT: ŻW - żwawość; PE - perseweratywność; WS - wrażliwość sensoryczna; RE - reaktywność emocjonalna; AK - aktywność; WT - wytrzymałość. Skale PKIE: AKC - akceptowanie; EMP - empatia; KON - kontrola; ROZ - rozumienie.

U mężczyzn struktura korelacji wygląda podobnie jak u kobiet; dla temperamentu nieco wyraźniejsze (niż u kobiet) jest powiązanie żwawości $\mathrm{z}$ inteligencją emocjonalną.

Analiza kolejnych korelacji kanonicznych została podjęta, żeby określić, czy pomiędzy badanymi zmiennymi istnieją związki o odmiennym charakterze jakościowym. Wagi i ładunki jednoznacznie wskazują, że druga korelacja kanoniczna odzwierciedla zależność między akceptowaniem emocji a aktywnością. Zależność między inteligencją emocjonalną a temperamentem opierająca się na związku aktywności i akceptowania 
emocji jest umiarkowana $\left(R_{c}=0,43\right)$. Ładunki krzyżowe rzędu 0,49-0,50 wskazują, że skala akceptowania jest w umiarkowanym stopniu związana z częścią struktury temperamentu $(18,2 \%$ - procent wariancji zmiennych wyjściowych wyjaśnionej przez ich funkcję kanoniczną oblicza się w następujący sposób: ładunki [loadings] każdej ze zmiennych podnosi się do kwadratu, następnie wyciąga się z nich średnią), a najbardziej w tej części struktury liczy się aktywność, natomiast aktywność jest w umiarkowanym stopniu związana z częścią struktury inteligencji emocjonalnej (24,6\%), najbardziej zależącą od akceptacji emocji. Można zauważyć, że korelacje między zmiennymi a przeciwnymi zmiennymi kanonicznymi są wyższe niż między wyjściowymi zmiennymi: aktywność i akceptowanie $(r=0,40)$; pozostałe zmienne $\mathrm{z}$ obu zestawów są słabo powiązane ze swoimi zmiennymi kanonicznymi, a tym bardziej - z przeciwnymi zmiennymi kanonicznymi. Ta sama zależność ujawniła się zarówno w grupie kobiet (tabela C5), jak i w grupie mężczyzn (tabela C6).

\section{Tabela C5}

Wskaźniki do interpretacji udziału poszczególnych zmiennych $w$ drugim pierwiastku kanonicznym $w$ grupie kobiet

\begin{tabular}{ccccc}
\hline Zestaw & Zmienna & Waga & $\mathbf{L}$ & $\boldsymbol{\Lambda}$ \\
\hline \multirow{2}{*}{ Inteligencja } & AKC & 1,00 & 0,73 & 0,40 \\
emocjonalna & EMP & $-0,02$ & 0,18 & 0,10 \\
& KON & $-0,27$ & $-0,38$ & $-0,21$ \\
& ROZ & $-0,52$ & $-0,33$ & $-0,18$ \\
& ŻW & 0,01 & 0,13 & 0,07 \\
Temperament & PE & 0,27 & 0,36 & 0,20 \\
& WS & 0,08 & 0,19 & 0,10 \\
& RE & 0,08 & 0,03 & 0,02 \\
& AK & 0,95 & 0,88 & 0,49 \\
& WT & $-0,26$ & $-0,20$ & $-0,11$ \\
\hline
\end{tabular}

Adnotacja. L - ładunek (loading) - korelacja zmiennej z własną zmienną kanoniczną; $\Lambda$ - „przeciwładunek” (cross-loading) - korelacja zmiennej z przeciwną zmienną 
kanoniczną. Skale FCZ-KT: ŻW - żwawość; PE - perseweratywność; WS - wrażliwość sensoryczna; RE - reaktywność emocjonalna; AK - aktywność; WT - wytrzymałość. Skale PKIE: AKC - akceptowanie; EMP - empatia; KON - kontrola; ROZ - rozumienie.

Wagi i ładunki w grupie mężczyzn przyjęły przeciwne znaki niż w grupie kobiet. Kierunek zależności pozostaje jednak taki sam: ujemna waga (i ładunek) - aktywność i ujemna waga (i ładunek) - akceptowanie dają w rezultacie dodatni ładunek krzyżowy (umiarkowany) jednej i drugiej zmiennej.

\section{Tabela C6}

Wskaźniki do interpretacji udziału poszczególnych zmiennych $w$ drugim pierwiastku kanonicznym w grupie mężczyzn

\begin{tabular}{ccccc}
\hline Zestaw & Zmienna & Waga & L & $\boldsymbol{\Lambda}$ \\
\hline \multirow{2}{*}{ Inteligencja } & AKC & $-0,96$ & $-0,73$ & $-0,48$ \\
emocjonalna & EMP & $-0,11$ & $-0,37$ & $-0,25$ \\
& KON & 0,52 & 0,43 & 0,28 \\
& ROZ & 0,29 & 0,12 & 0,08 \\
& ZW & 0,17 & 0,02 & 0,01 \\
Temperament & PE & $-0,69$ & $-0,58$ & $-0,38$ \\
& WS & $-0,12$ & $-0,22$ & $-0,15$ \\
& RE & 0,19 & $-0,03$ & $-0,02$ \\
& AK & $-0,79$ & $-0,71$ & $-0,47$ \\
& WT & 0,06 & 0,24 & 0,16 \\
\hline
\end{tabular}

Adnotacja. L - ładunek (loading) - korelacja zmiennej z własną zmienną kanoniczną; $\Lambda$ - „przeciwładunek” (cross-loading) - korelacja zmiennej z przeciwną zmienną kanoniczną. Skale FCZ-KT: ŻW - żwawość; PE - perseweratywność; WS - wrażliwość sensoryczna; RE - reaktywność emocjonalna; AK - aktywność; WT - wytrzymałość. Skale PKIE: AKC - akceptowanie; EMP - empatia; KON - kontrola; ROZ - rozumienie.

Ostatnią interpretowaną zależnością była trzecia - słaba, ale istotna - zależność zmiennych kanonicznych. Trzecia zmienna kanoniczna inteligencji emocjonalnej zależy w największym stopniu od zmienności empatii. Waga 
empatii jest co najmniej 1,67 razy większa niż wagi pozostałych zmiennych PKIE, a ładunek skali empatii wynosi 0,84. Wśród cech temperamentu największą wagę i najsilniejszy ładunek $(\mathrm{L}=0,81)$ ma wrażliwość sensoryczna. Związek między empatią i częścią temperamentu (14,8\% wariacji wszystkich zmiennych temperamentalnych) określoną przede wszystkim przez wrażliwość sensoryczną można już klasyfikować jako silny $(\Lambda=0,51)$ lub jeszcze umiarkowany. Związek między wrażliwością sensoryczną a częścią inteligencji emocjonalnej (19,8\% IE) determinowanej głównie przez empatię jest umiarkowany $(\Lambda=0,49)$. Struktura trzecich funkcji kanonicznych w grupie kobiet (tabela C7) i w grupie mężczyzn (tabela C8) jest zbliżona do omówionej powyżej.

\section{Tabela C7}

Wskaźniki do interpretacji udziału poszczególnych zmiennych $w$ trzecim pierwiastku kanonicznym $w$ grupie kobiet

\begin{tabular}{ccccc}
\hline Zestaw & Zmienna & Waga & $\mathbf{L}$ & $\boldsymbol{\Lambda}$ \\
\hline \multirow{2}{*}{ Inteligencja } & AKC & $-0,32$ & 0,01 & 0,00 \\
emocjonalna & EMP & 1,03 & 0,93 & 0,52 \\
& KON & $-0,22$ & $-0,17$ & $-0,10$ \\
& ROZ & 0,11 & 0,06 & 0,03 \\
& ZW & 0,19 & 0,22 & 0,12 \\
Temperament & PE & $-0,26$ & 0,13 & 0,07 \\
& WS & 0,87 & 0,83 & 0,46 \\
& RE & 0,71 & 0,34 & 0,19 \\
& AK & $-0,07$ & $-0,12$ & $-0,06$ \\
& WT & 0,25 & 0,08 & 0,05 \\
\hline
\end{tabular}

Adnotacja. L - ładunek (loading) - korelacja zmiennej z własną zmienną kanoniczną; $\Lambda$ - „przeciwładunek” (cross-loading) - korelacja zmiennej z przeciwną zmienną kanoniczną. Skale FCZ-KT: ŻW - żwawość; PE - perseweratywność; WS - wrażliwość sensoryczna; RE - reaktywność emocjonalna; AK - aktywność; WT - wytrzymałość. Skale PKIE: AKC - akceptowanie; EMP - empatia; KON - kontrola; ROZ - rozumienie. 


\section{Tabela C8}

Wskaźniki do interpretacji udziału poszczególnych zmiennych w trzecim pierwiastku kanonicznym w grupie mężczyzn

\begin{tabular}{ccccc}
\hline Zestaw & Zmienna & Waga & $\mathbf{L}$ & $\boldsymbol{\Lambda}$ \\
\hline \multirow{2}{*}{ Inteligencja } & AKC & $-0,60$ & $-0,08$ & $-0,05$ \\
emocjonalna & EMP & 1,00 & 0,84 & 0,55 \\
& KON & $-0,27$ & $-0,09$ & $-0,06$ \\
& ROZ & 0,39 & 0,22 & 0,15 \\
& ŻW & 0,35 & 0,27 & 0,18 \\
Temperament & PE & $-0,14$ & 0,14 & 0,09 \\
& WS & 0,84 & 0,82 & 0,54 \\
& RE & 0,74 & 0,30 & 0,20 \\
& AK & $-0,12$ & $-0,11$ & $-0,08$ \\
& WT & 0,15 & $-0,03$ & $-0,02$ \\
\hline
\end{tabular}

Adnotacja. L - ładunek (loading) - korelacja zmiennej z własną zmienną kanoniczną; $\Lambda$ - „przeciwładunek” (cross-loading) - korelacja zmiennej z przeciwną zmienną kanoniczną. Skale FCZ-KT: ŻW - żwawość; PE - perseweratywność; WS - wrażliwość sensoryczna; RE - reaktywność emocjonalna; AK - aktywność; WT - wytrzymałość. Skale PKIE: AKC - akceptowanie; EMP - empatia; KON - kontrola; ROZ - rozumienie. 


\section{Załącznik D. Typ temperamentu a inteligencja emocjonalna}

Tabela D1

Porównanie typów struktury temperamentu $w$ zakresie inteligencji emocjonalnej dla obu płci łącznie

\begin{tabular}{cccccc}
\hline & $\begin{array}{ccccc}\text { Zh DM } \\
(\mathbf{N}=\mathbf{1 2 9})\end{array}$ & $\begin{array}{c}\text { Zh MM } \\
(\mathbf{N}=\mathbf{1 1 7})\end{array}$ & $\begin{array}{c}\text { NZh DM } \\
(\mathbf{N}=\mathbf{4 9})\end{array}$ & $\begin{array}{c}\text { NZh MM } \\
(\mathbf{N}=\mathbf{6 2})\end{array}$ & $\begin{array}{c}\text { Test } \\
\text { Kruskala- } \\
\text { Wallisa }\end{array}$ \\
\hline Zmienna & śr. ranga & śr. ranga & śr. ranga & śr. ranga & $\mathbf{X}^{\mathbf{2}(3)}$ \\
\hline AKC & 244,75 & 107,85 & 168,63 & 184,65 & $108,78^{* * *}$ \\
EMP & 196,76 & 159,12 & 171,35 & 185,62 & $8,71^{*}$ \\
KON & 230,13 & 126,00 & 249,96 & 116,56 & $108,56^{* * *}$ \\
ROZ & 232,90 & 124,14 & 242,40 & 120,28 & $107,05^{* * *}$ \\
WO & 244,99 & 110,97 & 211,55 & 144,35 & $115,46^{* *}$ \\
\hline
\end{tabular}

Adnotacja. Skale PKIE: AKC - akceptowanie; EMP - empatia; KON - kontrola; ROZ - rozumienie; WO - wynik ogólny w PKIE; Zh DM - struktura zharmonizowana w połączeniu z dużymi możliwościami przetwarzania stymulacji; Zh MM - struktura zharmonizowana w połączeniu z małymi możliwościami przetwarzania stymulacji; Nzh DM - struktura niezharmonizowana w połączeniu z dużymi możliwościami przetwarzania stymulacji; Nzh MM - struktura niezharmonizowana w połączeniu z małymi możliwościami przetwarzania stymulacji.

${ }^{\star} p<0,05 ;{ }^{* * *} p<0,001$. 
Tabela D2

Proporcje osób o określonym profilu inteligencji emocjonalnej wewnątrz grup o poszczególnych typach struktury temperamentu w całej próbie

\begin{tabular}{ccccccc}
\hline Profil & Zh DM & Zh MM & NZh DM & NZh MM & $\begin{array}{c}\text { Nie- } \\
\text { określony }\end{array}$ & Ogółem \\
\hline STR & $59,4 \%^{* *}$ & $50,8 \%$ & $90,9 \%^{* * *}$ & $5,6 \%^{* * *}$ & $44,6 \%^{*}$ & $48,4 \%$ \\
DOŚW & $40,6 \%^{* *}$ & $49,2 \%$ & $9,1 \%^{* * *}$ & $94,4 \%^{* * *}$ & $55,4 \%^{*}$ & $51,6 \%$ \\
Ogółem & $100,0 \%$ & $100,0 \%$ & $100,0 \%$ & $100,0 \%$ & $100,0 \%$ & $100,0 \%$ \\
\hline
\end{tabular}

Adnotacja. STR - wysoka (lub przeciętna) inteligencja emocjonalna strategiczna; DOŚW - wysoka (lub przeciętna) inteligencja emocjonalna doświadczeniowa; Zh DM - struktura zharmonizowana w połączeniu z dużymi możliwościami przetwarzania stymulacji; Zh MM - struktura zharmonizowana w połączeniu z małymi możliwościami przetwarzania stymulacji; Nzh DM - struktura niezharmonizowana w połączeniu z dużymi możliwościami przetwarzania stymulacji; Nzh MM - struktura niezharmonizowana w połączeniu $\mathrm{z}$ małymi możliwościami przetwarzania stymulacji.

${ }^{\star} p<0,05 ;{ }^{* *} p<0,01 ;{ }^{* *} p<0,001$.

\section{Tabela D3}

Porównanie osób o dużych $(\mathrm{N}=178)$ i małych możliwościach $(\mathrm{N}=179)$ przetwarzania stymulacji pod względem inteligencji emocjonalnej $w$ całej próbie

\section{DM MM}

\begin{tabular}{ccccc} 
Zmienna & śr. ranga & śr. ranga & $\boldsymbol{U}$ & Efekt $\boldsymbol{r}$ \\
\hline $\begin{array}{c}\text { Przewaga } \\
\text { POZN }\end{array}$ & 150,96 & 206,89 & $10939,0^{* * *}$ & 0,27 \\
\hline
\end{tabular}

Adnotacja. Przewaga POZN - przewaga komponentu poznawczego nad działaniowym; DM - osoby o małych możliwościach przetwarzania stymulacji; DM - osoby o dużych możliwościach przetwarzania stymulacji.

$* * * p<0,001$. 
Tabela D4

Porównanie osób z przewaga komponentu działaniowego nad poznawczym $(\mathrm{N}=163)$ i osób z przewaga komponentu poznawczego nad działaniowym $(\mathrm{N}=157)$ pod względem cech temperamentu

\begin{tabular}{ccccc}
\hline & PD & PP & & \\
Zmienna & śr. ranga & śr. ranga & $\boldsymbol{U}$ & Efekt $\boldsymbol{r}$ \\
\hline ŻW & 165,39 & 155,43 & 11999,0 & 0,05 \\
PE & 152,90 & 168,39 & 11557,5 & 0,08 \\
WS & 147,77 & 173,72 & $10720,5^{*}$ & 0,14 \\
RE & 137,77 & 184,10 & $9090,0^{* * *}$ & 0,25 \\
AK & 178,09 & 142,24 & $9928,5^{* * *}$ & 0,19 \\
WT & 169,84 & 150,80 & 11273,0 & 0,10 \\
\hline
\end{tabular}

Adnotacja. PD - osoby o przewadze komponentu działaniowego nad komponentem poznawczym inteligencji emocjonalnej; PP - osoby o przewadze aspektu poznawczego nad aspektem działaniowym inteligencji emocjonalnej; ŻW - żwawość; PE - perseweratywość; WS - wrażliwość sensoryczna; RE - reaktywność emocjonalna; AK - aktywność; WT - wytrzymałość.

${ }^{\star} p<0,05 ;{ }^{* *} p<0,001$. 


\section{Tabela D5}

Proporcje osób o określonej relacji między komponentami inteligencji emocjonalnej w grupach o poszczególnych typach struktury temperamentu w całej próbie

\begin{tabular}{ccccccc}
\hline $\begin{array}{c}\text { Relacja } \\
\text { między } \\
\text { aspek- } \\
\text { tami }\end{array}$ & Zh DM & Zh MM & NZh DM & NZh MM & $\begin{array}{c}\text { Przecięt- } \\
\text { ny }\end{array}$ & Ogółem \\
\hline PD & $73,7 \%^{* * *}$ & $27,9 \%^{* * *}$ & $58,8 \%$ & $59,3 \%$ & $49,4 \%$ & $50,9 \%$ \\
PP & $26,3 \%^{* * *}$ & $72,1 \% \%^{* *}$ & $41,2 \%$ & $40,7 \%$ & $50,6 \%$ & $49,1 \%$ \\
Ogółem & $100,0 \%$ & $100,0 \%$ & $100,0 \%$ & $100,0 \%$ & $100,0 \%$ & $100,0 \%$ \\
\hline
\end{tabular}

Adnotacja. PD - przewaga aspektu działaniowego nad poznawczym; PP - przewaga aspektu poznawczego nad działaniowym; Zh DM - struktura zharmonizowana w połączeniu z dużymi możliwościami przetwarzania stymulacji; Zh MM - struktura zharmonizowana w połączeniu z małymi możliwościami przetwarzania stymulacji; Nzh DM - struktura niezharmonizowana w połączeniu z dużymi możliwościami przetwarzania stymulacji; Nzh MM - struktura niezharmonizowana w połączeniu z małymi możliwościami przetwarzania stymulacji.

${ }^{\star * *} p<0,001$. 

Za arcyciekawa uważam podjęta przez Autorkę (...) próbę odniesienia koncepcji inteligencji emocjonalnej do poznawczo-doświadczeniowej teorii osobowości Seymoura Epsteina. Jest to oryginalna perspektywa dająa nowe możliwości teoretycznych rozważań nad konstruktem inteligencji emocjonalnej.

Jestem przekonana, że podjęta $w$ książce problematyka może być interesująca dla różnych grup odbiorców. Pomimo naukowego charakteru, może ona znaleźć czytelników nie tylko wśród osób zajmujących się psychologia naukowo, ale również wśród psychologów - praktyków, pedagogów, a także wszystkich osób zainteresowanych inteligencją emocjonalną.

Głębsze zrozumienie temperamentalnych podstaw ksztaltowania się inteligencji emocjonalnej może mieć bowiem duże znaczenie m.in. dla konstruowania optymalnych oddzialywań psychoedukacyjnych, wychowawczych czy profilaktycznych, które moga stymulować rozwój zdolności emocjonalnych lub niwelować deficyty w ich zakresie.

dr Katarzyna Knopp

Joanna Pracka - doktor nauk społecznych, adiunkt w Instytucie Psychologii Uniwersytetu Szczecińskiego, psycholog i psychoterapeuta. W swojej pracy łączy poszukiwania naukowe z ich praktycznym zastosowaniem. 